\title{
OSCILAÇÕES SUBINERCIAIS NA PLATAFORMA CONTINENTAL SUDESTE: ESTUDOS NUMÉRICOS
}

Tese apresentada ao Instituto Oceanográfico da Universidade de São Paulo, como parte dos requisitos para obtenção do título de Doutor em Ciências, Programa de Oceanografia, área de Oceanografia Física

Orientador:

Prof. Dr. Belmiro Mendes de Castro Filho

S $\tilde{A}$ O P A U L O

2014 


\section{UNIVERSIDADE DE SÃO PAULO}

INSTITUTO OCEANOGRÁFICO

\section{OSCILAÇÕES SUBINERCIAIS NA PLATAFORMA CONTINENTAL \\ SUDESTE: ESTUDOS NUMÉRICOS \\ Hélvio Prevelato Gregório}

Tese apresentada ao Instituto Oceanográfico da Universidade de São Paulo, como parte dos requisitos para obtenção do título de Doutor em Ciências, Programa de Oceanografia, área de Oceanografia Física

Exame realizado em /2014 por

Prof. Dr. Belmiro Mendes de Castro Filho (orientador)

Prof. Dr.

Prof. Dr.

Prof. Dr.

Prof. Dr.

S Ã O P A U L O

2014 


\section{Sumário}

\begin{tabular}{lll}
\hline & Introdução & 1
\end{tabular}

1.1 Área de Estudo . . . . . . . . . . . . . . . . . . . . 4

1.1.1 A meteorologia sobre a Plataforma Continental Sudeste . . . . 6

1.1.2 A hidrografia da Plataforma Continental Sudeste . . . . . . 16

1.1 .3 As correntes na Plataforma Continental Sudeste . . . . . . . . 22

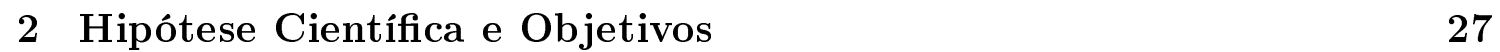

\begin{tabular}{lll}
\hline 3 & Metodologia & 28
\end{tabular}

3.1 Banco de dados atmosférico . . . . . . . . . . . . . . . 29

3.2 Estudo dos padrões atmosféricos sobre a Plataforma Continental Su-

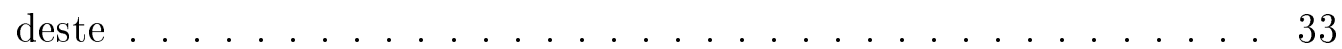

3.3 Experimentos numéricos $\ldots \ldots \ldots \ldots$. . . . . . . . . . . . . 36

3.4 Análises de Oscilações Subinerciais na Plataforma Continental Sudeste 42

\begin{tabular}{|lll}
\hline 4 & Resultados & $\mathbf{4 3}$
\end{tabular}

4.1 Validação do Banco de Dados Atmosférico . . . . . . . . . . . . . 43

4.2 Validação do Banco de Dados Oceânico . . . . . . . . . . . . . . . 55

$4.3 \quad$ Estudo dos padrões atmosféricos sobre a Plataforma Continental Su-

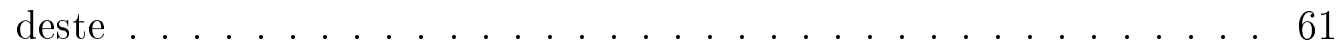

4.3 .1 Campos médios . . . . . . . . . . . . . . . . 61

4.3 .2 Perturbações sinóticas . . . . . . . . . . . . . . . . . . . . . . . . . . . . . . .

4.4 Experimentos com ventos reais . . . . . . . . . . . . . . 72

4.5 Experimentos com passagens de frentes . . . . . . . . . . . . 82

$\begin{array}{llr}5 & \text { Discussão } & 88\end{array}$

5.1 Bancos de dados atmosférico e oceânico . . . . . . . . . . . . . . 88

5.2 Padrões atmosféricos . . . . . . . . . . . . . . . . . . . 92

5.3 Características das Oscilações Subinerciais do nível do mar . . . . . . 98

$5.3 .1 \quad$ Propagação . . . . . . . . . . . . . . 100

5.3 .2 Confinamento . . . . . . . . . . . . . 108

5.3 .3 Resposta ao vento local e ao vento remoto . . . . . . . . . 112 
5.3.4 Resposta à forçantes externas da Plataforma Continental Sudeste . . . . . . . . . . . . . . . 120

5.3.5 Gênese das oscilações subinerciais na Plataforma Continental

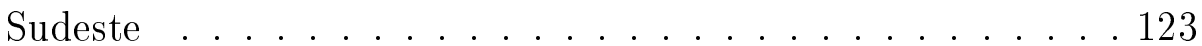

\begin{tabular}{llr}
\hline 6 & Conclusões & 127
\end{tabular}

\begin{tabular}{lll}
\hline 7 & Considerações Finais & 129
\end{tabular}

A O Modelo Numério DELFT3D-FLOW 139 
Ao meu pai, Hélvio Gregório (in memorian). 


\section{Agradecimentos}

Inicialmente gostaria de agradecer o Instituto Oceanográfico da Universidade de São Paulo que me proporcionou formação completa (graduação e pós-graduação) em ciências marinhas. Agradeço a todos os professores, técnicos e funcionários com os quais tive o prazer de aprender e conviver ao longo destes 12 anos.

Devido a minha escolha profissional, os últimos 7 anos foram de dupla jornada, dividindo meu tempo entre o trabalho fora da universidade e a minha pesquisa acadêmica. Portanto, meus agradecimentos aqui em grande parte se referem à pessoas que tiveram a sensibilidade de compreender esta minha escolha e, principalmente, a confiança e o incentivo em meus momentos de ausência.

Portanto, inicialmente é indispensável agradecer meu orientador, Prof. Dr. Belmiro Mendes de Castro Filho, pela confiança desde meu primeiro projeto de iniciação científica, passando pela segunda iniciação, mestrado e este doutoramento. Os ensinamentos adquiridos ao longo desta jornada, os incentivos e a forma como fui orientado me guiaram e me guiarão por toda minha carreira. Sou extremamente grato por tudo.

Agradeço os profissionais com os quais tive o prazer de trabalhar ao longo destes anos e que muito contribuíram com meu aprendizado: Dra. Adriene Pereira, Prof. Dr. Roberto Careli Fontes, Karina Corrêa, Hermínio Foloni Neto, Gabriel Paschoal, Alexandre de Caroli e todos os demais da Hidromares em Santos, Camila Rosso e demais profissionais do consórcio GeoHidroEco em Bogotá, Marcos Zabini, Ricardo Simonsen e todos os demais profissionais da Mineral Engenharia e Meio Ambiente, João Carlos Milanelli e todos os demais profissionais. Muito obrigado.

Agradeço os que colaboraram diretamente com este trabalho: os Profs. Drs. Ricardo de Camargo e Joseph Harari pelas valiosas contribuições no momento de minha qualificação, ao técnico Mauro Monteiro, do Labdados - IOUSP, pela disponibilização dos dados maregráficos da base de Ubatuba, ao GLOSS Brasil, representado pela Profa. Dra. Olga Sato, pelos demais dados maregráficos e de boias meteorológicas, e à Praticagem de Santos pelo fornecimento dos dados meteorológicos da cidade de Santos.

Gostaria também de agradecer imensamente todos os meus amigos que com toda amizade colaboraram indiretamente com este trabalho. Seria injustiça enorme me 
esquecer de algum nome, e assim prefiro agradecer de maneira geral todo o pessoal de Itu, de São Paulo e de todos os outros cantos do mundo. Enfim, muito obrigado por entender minha ausência e pelos ótimos momentos de presença. Vocês são incríveis e eu não teria conseguido concluir esta etapa sem o apoio de vocês.

Agradeço, de forma efusiva, minha mãe, Regina, e minhas irmãs, Érica e Núbia, pelo apoio incondicional em todos os momentos, inclusive naqueles de quase desistência. Não tenho palavras para descrever o tamanho do sentimento de gratidão e amor que tenho por vocês. Nunca teria conseguido atingir este objetivo sem vocês por perto. Obrigado pela compreensão pelos momentos de ausência e pela força nos momentos de fraqueza. Vocês são as mulheres da minha vida!

Meus mais sinceros agradecimentos à Thaís Guimarães-Dogimont, pelo tratamento, conforto, profissionalismo e apoio. Eu não reagiria sem a sua ajuda. Da mesma forma não posso deixar de agradecer à Lívia, que me acompanhou durante um longo período desta jornada, me ajudando a crescer e me transmitindo ensinamentos valiosos. Serei sempre seu fã incondicional, torcendo e tendo orgulho de seus feitos. Obrigado por tudo.

Por fim, gostaria de fazer um agradecimento especial a Mechi, que me resgatou quando eu já estava a deriva, e com todo o carinho e atenção, desde o início, me deu forças para chegar até o final. As vezes não compreendemos o porquê do destino nos dar algumas rasteiras, mas também esquecemos de agradecer os presentes que ele nos proporciona. Obrigado por todo o entusiasmo, atenção e interesse em minha pesquisa, mesmo sendo uma coisa totalmente nova para você. Obrigado pelos desenhos, aquarelas e preocupação em todos os momentos. Você foi incrível. 


\section{Resumo}

Oscilações subinerciais da elevação da superfície livre do mar na Plataforma Continental Sudeste (PCSE) foram estudadas por meio de modelagem numérica computacional. Os campos atmosféricos utilizados nos experimentos foram obtidos da reanálise NCEP-DOE AMIP II e o modelo hidrodinâmico DELFT-3D Flow foi empregado. A validação dos resultados dos experimentos numéricos foi realizada por comparação com observações. Foram realizadas simulações para o verão de 2003, para o inverno de 2004 e para mais quatro cenários de ventos sintéticos, simulando a propagação de frentes frias climatológicas (obtidas neste estudo). Verificamos que na porção sul (norte) da região passaram 3,6 $(2,9)$ frentes frias por mês durante o inverno e 3,4 (1,3) durante o verão. Esta diferença entre as regiões norte e sul mostrou que alguns eventos não percorrem toda a região, sendo mais frequente no verão. A passagem de frentes frias provocou a propagação de oscilações subinerciais da superfície do mar, confinadas junto à costa, com comprimento de onda de aproximadamente $2000 \mathrm{~km}$, duração de $50 \mathrm{~h}$ e amplitude média de 0,3 m, tanto no verão quanto no inverno. Nas simulações em que as frentes frias não percorreram toda a PCSE, oscilações na superfície do mar também foram geradas e se propagaram para o norte com características semelhantes àquelas geradas pelas frentes frias que percorreram toda a PCSE. As oscilações subinerciais na região norte estiveram melhor correlacionadas com a componente do vento perpendicular à costa da região de Paranaguá-Cananéia e com a componente do vento paralelo à costa da região de Imbituba-São Francisco. Forçantes externas à FPSE também excitaram oscilações subinerciais, principalmente com períodos superiores a 7 dias. As oscilações subinerciais com períodos inferiores (superiores) a 7 (9) dias foram geradas desde o extremo sul (ao sul) da PCSE até a região de Cananéia-Paranaguá e contribuíram com cerca de $40 \%(12 \%)$ da variância subinercial. As oscilações subinerciais analisadas tiveram características de Ondas de Plataforma Continental.

Descritores: Oscilações Subinerciais, Plataforma Continental Sudeste, Frentes Frias, Ondas de Plataforma Continental. 


\section{Abstract}

The subinertial oscillations of the sea level in the South Brazil Bight (SBB) were studied using computational numerical models. The atmospheric fields used in the experiments were obtained from NCEP - DOE AMIP II reanalysis and the DELFT - 3D Flow hydrodynamic model was used. The validation of the numercial experiments was conducted by comparison with observations. Simulations were conducted for the summer 2003, winter 2004 and for others four scenarios with synthetic winds, simulating the cold fronts propagation (attained in this study). We verified that in the south (north) part of SBB there were 3.6 (2.9) passing through during the winter and 3.4 (1.3) during the summer. This difference between the south and north regions showed that some part of events did not cover the whole SBB, being this more frequent during the summer. The cold front passages excited the propagation of subinertail sea level oscillations, trapped along the coastline, with approximately $2000 \mathrm{~km}$ of wavelength, $50 \mathrm{~h}$ of duration and $0.3 \mathrm{~m}$ of mean amplitude, both in the summer and in the winter. In the simulations in that the cold front did not pass through the whole SBB, sea level subinertial oscillations were also generated and propagated towards north with characteristics similar to the ones generated by cold fronts that passed through the whole SBB. The subinertial oscillations in the north part of SBB were better correlated with the wind component perpendicular to the coastline in the Paranaguá-Cananéia region and with the wind component parallel to the coastline in the Imbituba-São Francisco region. Forcing external to the SBB also excited subinertial oscillations with periods lower (higher) than 7 (9) days were generated from the south boundary of the SBB (south of the SBB) to the Cananéia-Paranaguá region and contributed with approximately 40\% (12\%) of the subinertial variance. The subinertiacl oscillations analyzed had characteristics of Continental Shelf Waves.

Keywords: Subinertial Oscillations, South Brazil Bight, Cold Fronts, Continental Shelf Waves. 


\section{Lista de Figuras}

1.1 Plataforma Continental Sudeste e algumas localidades. A isobatimé-

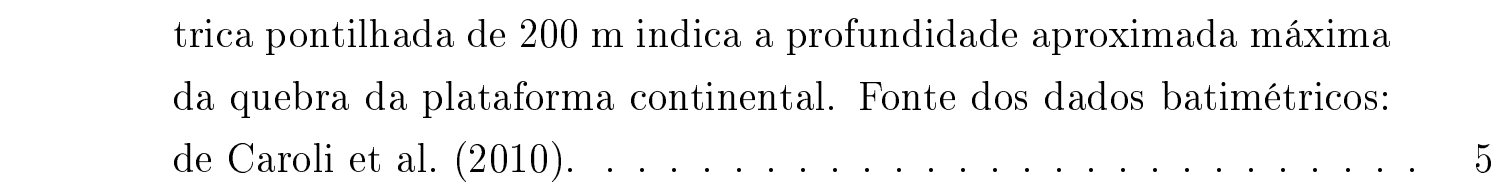

1.2 Pressão atmosférica indicando o posicionamento dos sistemas Antici-

\begin{tabular}{|c|}
\hline clone Subtropical do Pacífico Sul (ASPS) e do Anticiclone Subtropical \\
\hline do Atlântico Sul (ASAS) no verão. Fonte de dados: Reanálise NCEP- \\
\hline DOF AMIP II (Kanamitsura et al. 2002)
\end{tabular}

1.3 Pressão atmosférica indicando o posicionamento dos sistemas Anticiclone Subtropical do Pacífico Sul (ASPS) e do Anticiclone Subtropi-

cal do Atlântico Sul (ASAS) no inverno. Fonte de dados: Reanálise

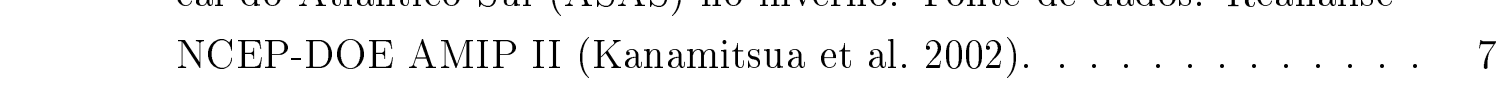

1.4 Imagens de satélite na banda do visível exemplificando uma frente

\begin{tabular}{|l|}
\hline fria que percorreu toda a Plataforma Continental Sudeste. O pai- \\
\hline nel (a) é referente ao dia 18/08/2011, o (b) ao dia 19/08/2011, (c) \\
\hline \hline $20 / 08 / 2011$, (d) $21 / 08 / 2011$, (e) $23 / 08 / 2011$ e (f) $24 / 08 / 2011$. Fonte: \\
\hline CPTEC/INPE. . . . . . . . . . . . . . . . . . . . . . 9 9
\end{tabular}

1.5 Pressão atmosférica ( $\mathrm{hPa}$ - cores) e vento à $10 \mathrm{~m}$ (vetores) de um exemplo de uma frente fria sobre a Plataforma Continental Sudeste.

\begin{tabular}{|c|}
\hline O painel (a) é referente ao dia 18/08/2011, o (b) ao dia 19/08/2011, \\
\hline (c) $20 / 08 / 2011$, (d) $21 / 08 / 2011$, (e) $23 / 08 / 2011$ e (f) $24 / 08 / 2011$. Os \\
\hline três pontos no painel (a) referem-se a posições utilizadas na Figura \\
\hline \begin{tabular}{|l|l|l}
1.6 & Fonte de dados: Reanálise NCEP-DOE AMIP II (Kanamitsua
\end{tabular} \\
\hline
\end{tabular}

1.6 Variação do vento à $10 \mathrm{~m}$ (painel superior), pressão atmosférica (painel central) e temperatura superficial (painel inferior) de um exemplo de frente fria sobre a Plataforma Continental Sudeste. As cores de cada linha representam séries nos pontos de mesma cor apresentados \begin{tabular}{|l|l|l|}
\hline no painel superior esquerdo da Figura & 1.5 & Fonte de dados: Reanálise \\
\hline
\end{tabular} NCEP-DOE AMIP II (Kanamitsua et al.||2002). . . . . . . . . . . . . 11 
1.7 $\quad$ Imagens de satélite na banda do visível exemplificando uma frente fria que não percorreu toda a extensão da PCSE. O painel (a) é referente ao dia 31/01/2011, o (b) ao dia 01/02/2011, (c) 02/02/2011, (d) 03/02/2011, (e) 04/02/2011 e (f) 05/02/2011. Fonte: CPTEC/INPE. 13

1.8 Pressão atmosférica (hPa - cores) e vento à $10 \mathrm{~m}$ (vetores) de um exemplo de frente fria que não percorreu toda a extensão da PCSE. O painel (a) é referente ao dia 31/01/2011, o (b) ao dia 01/02/2011, (c) $02 / 02 / 2011$, (d) 03/02/2011, (e) 04/02/2011 e (f) 05/02/2011. Os três pontos no painel (a) referem-se a posições utilizadas na 1.9 . Fonte de dados: Reanálise NCEP-DOE AMIP II (Kanamitsua et al. 2002). . . . . . . . . . . . . . . . . 14

1.9 Variação do vento à $10 \mathrm{~m}$ (painel superior), pressão atmosférica (painel central) e temperatura superficial (painel inferior) de um exemplo de frente fria que não percorreu toda a extensão da PCSE. As cores de cada linha representam séries nos pontos de mesma cor apresentados no painel superior esquerdo da Figura 1.8 . Fonte de dados: Reanálise NCEP-DOE AMIP II (Kanamitsua et al.|2002). . . . . . . . . . . . . 15

1.10 Modelo conceitual de passagem de frente fria sobre a Plataforma Con\begin{tabular}{|c|c|c|}
\hline tinental Sudeste para o inverno, de acordo com Stech \& Lorenzzetti \\
\hline
\end{tabular}

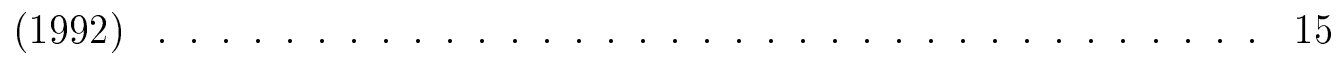

1.11 Diagrama T-S de verão para a Plataforma Continental Sudeste a partir de dados históricos observacionais. ACAS: Água Central do Atlântico Sul; AT: Água Tropical. Fonte: adaptado de Rezende[(2003) 17

1.12 Seções horizontais de salinidade média, em superfície (superior esquerdo), $20 \mathrm{~m}$ (superior direito), $50 \mathrm{~m}$ (centro esquerdo), $100 \mathrm{~m}$ (centro direita), $200 \mathrm{~m}$ (inferior esquerdo) e no fundo (inferior direito) da Plataforma Continental Sudeste. Fonte: adaptado de Rezende $[(2003)] 19$

1.13 Seções horizontais de temperatura média, em superfície (superior esquerdo), $20 \mathrm{~m}$ (superior direito), $50 \mathrm{~m}$ (centro esquerdo), $100 \mathrm{~m}$ (centro direita), $200 \mathrm{~m}$ (inferior esquerdo) e no fundo (inferior direito) da Plataforma Continental Sudeste. Fonte: adaptado de Rezende $[(2003)] 20$

1.14 Distribuição horizontal superficial de temperatura média para a Pla-

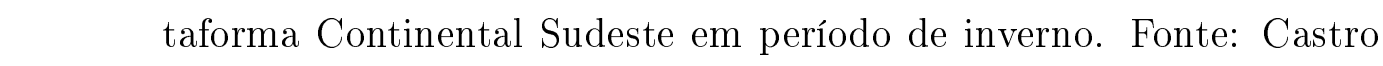
\& Miranda (1998)]. . . . . . . . . . . . . . . 21

1.15 Distribuição horizontal superficial de salinidade média para a Plataforma Continental Sudeste em período de inverno. Fonte: Castro \&

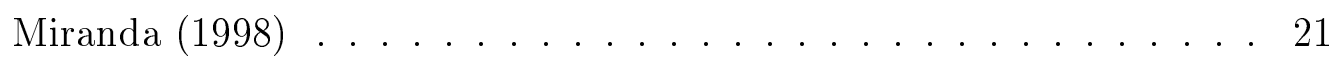


1.16 Esquema da compartimentação dinâmica da Plataforma Continental

\begin{tabular}{|l|}
\hline Sudeste. PCI: plataforma continental interna; PCM: plataforma con- \\
\hline \hline tinental média; PCE: plataforma continental externa; ACAS: Água \\
\hline \hline Central do Atlântico Sul; AT: Água Tropical. A seta vermelha indica \\
\hline corrente gerada por gradiente de densidade, as setas azuis correntes \\
\hline forçadas pelo vento sinótico e a seta verde a Corrente do Brasil. Fonte: \\
\hline Adaptado de Castro (1996). . . . . . . . . . . . . . . . . . . . . . 2 26
\end{tabular}

$3.1 \quad$ Metodologia utilizada nesta tese de doutorado para estudo das oscilações subinerciais na Plataforma Continental Sudeste. . . . . . . . 28

3.2 Localização de pontos de coleta dos dados que foram utilizados para validar os bancos de dados atmosférico (NCEP-DOE AMIP II) e oceânico (modelagem numérica). Fonte dos dados batimétricos de acordo . com de Caroli et al. $(2010)$. . . . . . . . . . . . . . . 32

3.3 Grade da reanálise NCEP-DOE AMIP II e os três pontos de análise \begin{tabular}{|c|}
\hline de passagens de frentes frias (painel (a)). O painel (b) mostra a grade \\
\hline
\end{tabular} de interpolação e os pontos de análise das frentes frias médias obtidas \begin{tabular}{|c|}
\hline pelo estudo de padrões de ventos sobre a Plataforma Continental \\
\hline
\end{tabular}

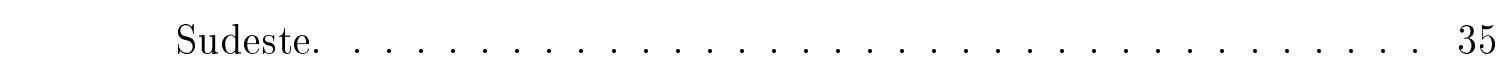

3.4 Representação gráfica da grade numérica implementada para a realização dos experimentos numéricos que compuseram o BDOs. No detalhe está representada a porção centro-norte do litoral de SP de\begin{tabular}{|c|}
\hline talhando a resolução empregada na região costeira da Plataforma \\
\hline
\end{tabular} - Continental Sudeste. . . . . . . . . . . . . . . . 38

3.5 Da esquerda para a direita: perfil vertical de salinidade, tempera\begin{tabular}{|l|}
\hline tura e densidade utilizados nos experimentos numéricos (linha preta \\
\hline \hline perfil anual, vermelha verão e azul inverno). No painel da direita a \\
\hline distribuição vertical da coordenadas sigma introduzidas no modelo. . 39
\end{tabular}

3.6 Localização das radiais quase perpendiculares à batimetria da Pla\begin{tabular}{|c|}
\hline taforma Continental Sudeste. No quadro, em destaque, a orientação \\
\hline dos eixos cartesianos locais adotados nas análises das Oscilaç̃es Su- \\
\hline
\end{tabular}

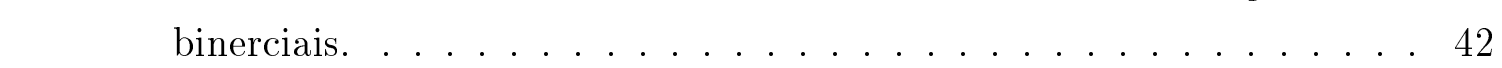

4.1 Séries de tempo dos dados totais da componente do vento perpendicular à costa do banco de dados atmosférico (linhas pretas) e dos \begin{tabular}{|c|}
\hline dados coletados em estações meteorológicas oceânicas (linhas verme- \\
\hline lhas) na Plataforma Continental Sudeste. Os locais representativos \\
\hline
\end{tabular}

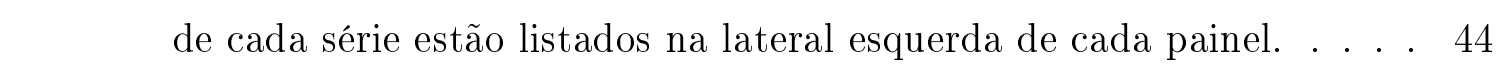


4.2 Séries de tempo dos dados totais da componente do vento paralelo \begin{tabular}{|l|}
\hline à costa do banco de dados atmosférico (linhas pretas) e dados co- \\
\hline letados em estações meteorológicas oceânicas (linhas vermelhas) na \\
\hline Plataforma Continental Sudeste. Os locais representativos de cada \\
\hline série estão listados na lateral esquerda de cada painel. . . . . . . . . . . 44
\end{tabular}

4.3 Séries de tempo dos dados totais da componente do vento perpendi\begin{tabular}{|c|}
\hline cular à costa do banco de dados atmosférico (linhas pretas) e dados \\
\hline coletados em estações meteorológicas costeiras (linhas vermelhas) na \\
\hline Plataforma Continental Sudeste. Os locais representativos de cada \\
\hline série estão listados na lateral esquerda de cada painel. . . . . . . . . . . 45
\end{tabular}

4.4 Séries de tempo dos dados totais da componente do vento paralelo à costa do banco de dados atmosférico (linhas pretas) e dados coletados em estações meteorológicas costeiras (linhas vermelhas) na Plataforma Continental Sudeste. Os locais representativos de cada

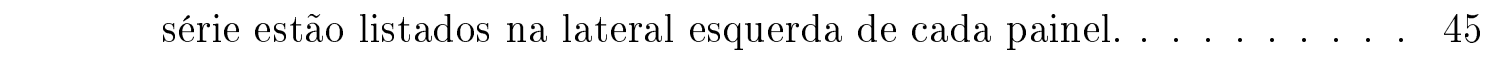

4.5 Séries de tempo dos dados totais de pressão atmosférica do banco de dados atmosférico (linhas pretas) e dados coletados em estações meteorológicas oceânicas (linhas vermelhas) na Plataforma Continen\begin{tabular}{|c|}
\hline tal Sudeste. Os locais representativos de cada série estão listados na \\
\hline
\end{tabular} lateral esquerda de cada painel. . . . . . . . . . . . . . . 46

4.6 Séries de tempo dos dados totais de pressão atmosférica do banco de dados atmosférico (linhas pretas) e dados coletados em estações meteorológicas costeiras (linhas vermelhas) na Plataforma Continen\begin{tabular}{|c|}
\hline tal Sudeste. Os locais representativos de cada série estão listados na \\
\hline
\end{tabular} lateral esquerda de cada painel. . . . . . . . . . . 46

4.7 Séries de tempo dos dados subinerciais do componente do vento perpendicular à costa do banco de dados atmosférico (linhas pretas) e dados coletados em estações meteorológicas oceânicas (linhas verme\begin{tabular}{|c|}
\hline lhas) na Plataforma Continental Sudeste. Os locais representativos \\
\hline
\end{tabular}

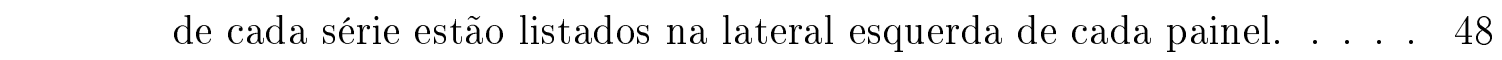

4.8 Séries de tempo dos dados subinerciais do componente do vento per\begin{tabular}{|c|}
\hline pendicular à costa do banco de dados atmosférico (linhas pretas) e \\
\hline dados coletados em estações meteorológicas costeiras (linhas verme- \\
\hline lhas) na Plataforma Continental Sudeste. Os locais representativos \\
\hline de cada série estão listados na lateral esquerda de cada painel. . . . . 48
\end{tabular} 
4.9 Séries de tempo dos dados subinerciais do componente do vento pa\begin{tabular}{|l|}
\hline ralelo à costa do banco de dados atmosférico (linhas pretas) e dados \\
\hline coletados em estações meteorológicas oceânicas (linhas vermelhas) na \\
\hline Plataforma Continental Sudeste. Os locais representativos de cada \\
\hline série estão listados na lateral esquerda de cada painel. . . . . . . . . . . 49
\end{tabular}

4.10 Séries de tempo dos dados subinerciais do componente do vento paralelo à costa do banco de dados atmosférico (linhas pretas) e dados coletados em estações meteorológicas costeiras (linhas vermelhas) na \begin{tabular}{|l|}
\hline Plataforma Continental Sudeste. Os locais representativos de cada \\
\hline
\end{tabular}

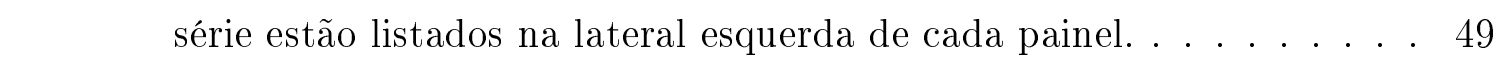

4.11 Séries de tempo dos dados subinerciais de pressão atmosférica do \begin{tabular}{|c|}
\hline banco de dados atmosférico (linhas pretas) e dados coletados em esta- \\
\hline ções meteorológicas oceânicas (linhas vermelhas) na Plataforma Con- \\
\hline tinental Sudeste. Os locais representativos de cada série estão listados \\
\hline na lateral esquerda de cada painel. . . . . . . . . . . . . . . . . . . . . 50
\end{tabular}

4.12 Séries de tempo dos dados subinerciais de pressão atmosférica do banco de dados atmosférico (linhas pretas) e dados coletados em \begin{tabular}{|c|}
\hline estações meteorológicas costeiras (linhas vermelhas) na Plataforma \\
\hline Contina
\end{tabular} Continental Sudeste. Os locais representativos de cada série estão listados na lateral esquerda de cada painel. . . . . . . . . . . . . 50

4.13 Energia cinética média para as simulações de aquecimento do modelo \begin{tabular}{|c|c|}
\hline numérico. São apresentados somente os resultados para as $350 \mathrm{~h}$ \\
\hline
\end{tabular} iniciais de simulação. . . . . . . . . . . . . . . . 56

4.14 Séries de tempo de elevação total da superfície livre do mar modelada \begin{tabular}{|c|}
\hline (Experimento 1A - linha preta) e observada (linha vermelha) durante \\
\hline
\end{tabular} \begin{tabular}{|c|}
\hline o verão de 2003. Os locais representativos de cada série estão listados \\
\hline
\end{tabular} na lateral esquerda de cada painel. . . . . . . . . . . . . . . 57

4.15 Séries de tempo de elevação total da superfície livre do mar mode\begin{tabular}{|c|}
\hline lada (Experimento 1B - linha preta) e observada (linha vermelha) \\
\hline
\end{tabular} durante o inverno de 2004. Os locais representativos de cada série estão listados na lateral esquerda de cada painel. . . . . . . . . . . . . 57

4.16 Séries de tempo de elevação subinercial da superfície livre do mar mo\begin{tabular}{|c|}
\hline delada (Experimento 1A - linha preta) e observada (linha vermelha) \\
\hline
\end{tabular} durante o verão de 2003. Os locais representativos de cada série estão listados na lateral esquerda de cada painel. . . . . . . . . . . . . 58

4.17 Séries de tempo de elevação subinercial da superfície livre do mar mo\begin{tabular}{|c|}
\hline delada (Experimento 1B - linha preta) e observada (linha vermelha) \\
\hline
\end{tabular} durante o inverno de 2004. Os locais representativos de cada série estão listados na lateral esquerda de cada painel. . . . . . . . . . . . 58 
4.18 Vento médio (nível $10 \mathrm{~m}$ ) para o verão (painel da esquerda) e para o inverno (painel da direita). . . . . . . . . . . . . . . . 61

4.19 Variância média (cores $\mathrm{em} \mathrm{m}^{2} . \mathrm{s}^{-2}$ ) da componente zonal do vento para o verão (painel da esquerda) e para o inverno (painel da direita). 62

4.20 Variância média (cores $\mathrm{em}^{2} \cdot \mathrm{s}^{-2}$ ) da componente meridional do \begin{tabular}{|c|}
\hline vento o verão (painel da esquerda) e para o inverno (painel da di- \\
\hline
\end{tabular} reita). . . . . . . . . . . . . . 62

4.21 Temperatura atmosférica média em ${ }^{\circ} \mathrm{Cno}$ nível de $0 \mathrm{~m}$, para o verão

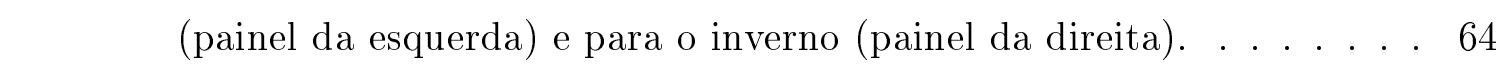

4.22 Variância (cores em $\left.\left({ }^{\circ} \mathrm{C}\right)^{2}\right)$ da temperatura atmosférica no nível $0 \mathrm{~m}$ \begin{tabular}{|c|c|}
\hline para o verão (painel da esquerda) e para o inverno (painel da direita). 64 \\
\hline
\end{tabular}

4.23 Pressão atmosférica média (cores em hPa) para o verão (painel da

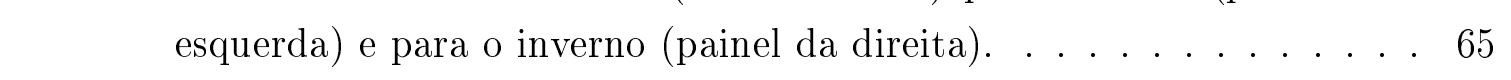

4.24 Variância da pressão atmosférica (cores em $\mathrm{hPa}^{2}$ ) para o verão (painel

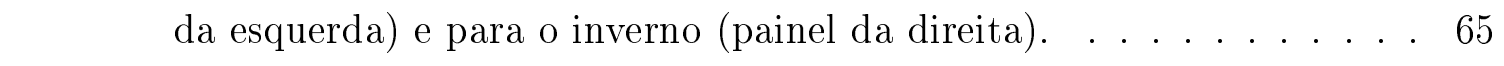

4.25 Frente fria média de verão que percorre toda a extensão da PCSE. Nos painéis superiores, vetores velocidade do vento em instantes de acordo com os subtítulos. No painel da segunda linha, de cima para baixo, variação temporal do vetor vento nos pontos demarcados em azul \begin{tabular}{|c|}
\hline (PSC), verde (PSP) e vermelho (PRJ) de acordo com os pontos nos \\
\hline mapas. Para
\end{tabular} \begin{tabular}{|c|}
\hline mapas. Para estes pontos também é apresentada a variação temporal \\
\hline da pressão atmosférica (painel da terceira linha de cima para baixo)
\end{tabular} e da temperatura atmosférica superficial (painel inferior). . . . . . . . 68

4.26 Frente fria média de verão que não percorre toda a extensão da PCSE. Nos painéis superiores, vetores velocidade do vento em instantes de acordo com os subtítulos. No painel da segunda linha, de cima para \begin{tabular}{|c|}
\hline baixo, variação temporal do vetor vento nos pontos demarcados em \\
\hline
\end{tabular} \begin{tabular}{|c|}
\hline azul (PSC), verde (PSP) e vermelho (PRJ) de acordo com os pontos \\
\hline
\end{tabular} nos mapas. Para estes pontos também é apresentada a variação temporal da pressão atmosférica (painel da terceira linha de cima para

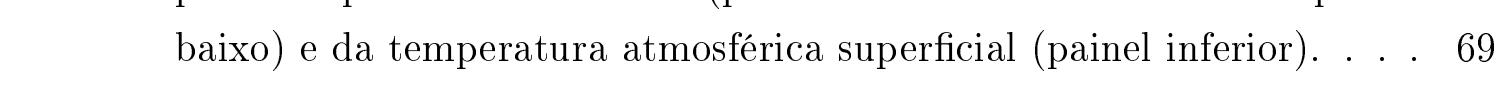

4.27 Frente fria média de inverno que percorre toda a extensão da PCSE.

\begin{tabular}{|c|}
\hline Nos painéis superiores, vetores velocidade do vento em instantes de \\
\hline acordo com os subtítulos. No painel da segunda linha, de cima para \\
\hline baixo, variação temporal do vetor vento nos pontos demarcados em \\
\hline azul (PSC), verde (PSP) e vermelho (PRJ) de acordo com os pontos \\
\hline nos mapas. Para estes pontos também é apresentada a variação tem- \\
\hline poral da pressão atmosférica (painel da terceira linha de cima para \\
\hline baixo) e da temperatura atmosférica superficial (painel inferior). . . . 70 \\
\hline
\end{tabular}


4.28 Frente fria média de inverno que não percorre toda a extensão da PCSE. Nos painéis superiores, vetores velocidade do vento em instantes de acordo com os subtítulos. No painel da segunda linha, de cima para baixo, variação temporal do vetor vento nos pontos de-

\begin{tabular}{|c|}
\hline marcados em azul (PSC), verde (PSP) e vermelho (PRJ) de acordo \\
\hline com os pontos nos mapas. Para estes pontos também é apresentada \\
\hline a variação temporal da pressão atmosférica (painel da terceira linha \\
\hline de cima para baixo) e da temperatura atmosférica superficial (painel \\
\hline inferior). . . . . . . . . . . . . . . . . . . . . . 71
\end{tabular}

4.29 Vetores velocidade subinercial do vento para o verão de 2003 , de acordo com os locais descritos à esquerda dos gráficos. O vetor de referência está localizado no canto superior esquerdo. O norte aponta - para cima. . . . . . . . . . . . . . . 73

4.30 Vetores velocidade subinercial do vento para o inverno de 2004 , de \begin{tabular}{|c|}
\hline acordo com os locais descritos à esquerda dos gráficos. O vetor de \\
\hline
\end{tabular} \begin{tabular}{|c|}
\hline referência está localizado no canto superior esquerdo. O norte aponta \\
\hline
\end{tabular} para cima. . . . . . . . . . . . . . . . . . 74

4.31 Isolinhas dos espectros de potência para a componente do vento perpendicular à costa para o verão de 2003 (superior) e inverno de 2004 (inferior), em função da distância ao longo da costa (ordenadas) e do período (abcissas). São apresentadas as potências mínimas com confiabilidade estatística de $95 \%$ e 10,5 graus de liberdade. . . . . . 76

4.32 Isolinhas dos espectros de potência para a componente do vento pa\begin{tabular}{|l|}
\hline ralelo à costa para o verão de 2003 (superior) e inverno de 2004 (in- \\
\hline ferior), em função da distância ao longo da costa (ordenadas) e do \\
\hline período (abcissas). São apresentadas as potências mínimas com con- \\
\hline fiabilidade estatística de $95 \%$ e 10,5 graus de liberdade. . . . . . . . . 76
\end{tabular}

4.33 Pressão atmosférica subinercial no verão de 2003 nos locais descritos a à esquerda dos gráficos. . . . . . . . . . . . . . . . . 77

4.34 Pressão atmosférica subinercial no inverno de 2004 nos locais descritos - à esquerda dos gráficos. . . . . . . . . . . . . . . 78

4.35 Isolinhas dos espectros de potência para pressão atmosférica para o \begin{tabular}{|l|}
\hline verão de 2003 (superior) e inverno de 2004 (inferior), em função da \\
\hline \hline distância ao longo da costa (ordenadas) e do período (abcissas). São \\
\hline apresentadas as potências mínimas com confiabilidade estatística de \\
\hline 95\% e 10,5 graus de liberdade. . . . . . . . . . . . . . 79
\end{tabular}

4.36 Nível do mar subinercial modelado no verão de 2003 (Experimento

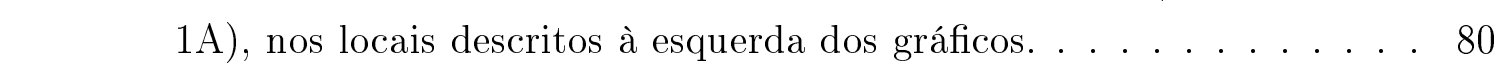


4.37 Nível do mar subinercial modelado no inverno de 2004 (Experimento 1B), nos locais descritos à esquerda dos gráficos. . . . . . . . . . . 81

4.38 Isolinhas dos espectros de potência para a oscilação da superfície livre do mar para o verão de 2003 (superior) e inverno de 2004 (inferior), em função da distância ao longo da costa (ordenadas) e do período

(abcissas). São apresentadas as potências mínimas com confiabilidade
estatística de $95 \%$ e 10,5 graus de liberdade. . . . . . . . . . . . . . . 82

4.39 Corrente verticalmente integrada (vetores) e nível do mar (cores) subi-

\begin{tabular}{|c|}
\hline nerciais para instantes de tempo (descritos no título dos painéis) para \\
\hline passagem de frente fria em período de verão, modeladas no Experi- \\
\hline mento 2A. Os vetores foram reamostrados espacialmente para facilitar \\
\hline a visualização. . . . . . . . . . . . . . . . . . . . . . . . . 84
\end{tabular}

4.40 Corrente verticalmente integrada (vetores) e nível do mar (cores) subinerciais para instantes de tempo (descritos no título dos painéis) para passagem de frente fria em período de inverno, modeladas no Experimento 2B. Os vetores foram reamostrados espacialmente para facilitar a visualização. . . . . . . . . . . . . . . . 85

4.41 Corrente verticalmente integrada (vetores) e nível do mar (cores) subinerciais para instantes de tempo (descritos no título dos painéis) para passagem de frente fria em período de verão que não percorrem toda a extensão da PCSE, modeladas no Experimento 3A. Os vetores foram reamostrados espacialmente para facilitar a visualização. . . . . 86

4.42 Corrente verticalmente integrada (vetores) e nível do mar (cores) su\begin{tabular}{|c|}
\hline binerciais para instantes de tempo (descritos no título dos painéis) \\
\hline para passagem de frente fria em período de inverno que não percor- \\
\hline rem toda a extensão da PCSE, modeladas no Experimento 3B. Os \\
\hline vetores foram reamostrados espacialmente para facilitar a visualizacão. 87
\end{tabular}

5.1 Resultados dos métodos estatísticos de comparação entre dados totais coletados e o BDA. O painel superior mostra as comparações para a componente do vento perpendicular à costa, o central para a componente do vento paralela à costa e o painel inferior a comparação para - a pressão atmosférica. . . . . . . . . . . . . . . . 89

5.2 Resultados dos métodos estatísticos de comparação entre dados subinerciais coletados e o BDA. O painel superior mostra as comparações para a componente do vento perpendicular à costa, o central para a componente do vento paralela à costa e o painel inferior a comparação para a pressão atmosférica. . . . . . . . . . . . . . . . . 90 90 
5.3 Resultados dos métodos estatísticos de comparação entre dados totais coletados e o BDO (experimentos numéricos). O painel superior mostra a comparação para a elevação da superfície do mar, no verão, e o painel inferior para a elevação da superfície do mar no inverno . . 91

5.4 Resultados dos métodos estatísticos de comparação entre dados su-

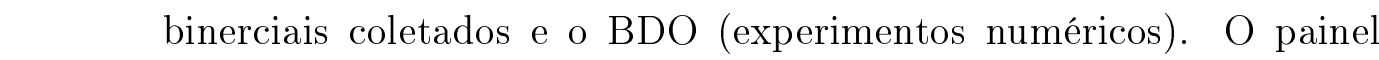
superior mostra a comparação para a elevação da superfície do mar, \begin{tabular}{|c|}
\hline no verão, e o painel inferior para a elevação da superfície do mar no \\
\hline
\end{tabular}

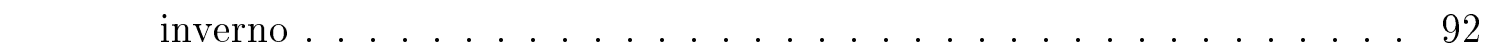

5.5 No painel (a) tempo de deslocamento (eixo das ordenadas) e localização geográfica (eixo das abscissas) das FF médias. Em (b) magnitude da velocidade de deslocamento (eixo das ordenadas) das FF médias em função do tempo de deslocamento (eixo das abcissas). . . . . . . . 96

5.6 Nos painéis em superiores skill médio da componente zonal do vento, entre a FF média de verão (esquerda) e todas as demais identificadas e entre a FF média de inverno (direita) e todas as demais identifica\begin{tabular}{|c|}
\hline das. Os painéis inferiores são similares aos superiores, contudo para \\
\hline
\end{tabular}

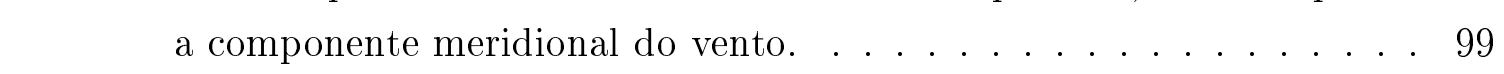

5.7 Elevação subinercial da superfície do mar modelada para passagem \begin{tabular}{|c|}
\hline de frente fria média no verão (experimento $2 \mathrm{~A}$ ), de acordo com os \\
\hline
\end{tabular} - locais descritos à esquerda dos gráficos. . . . . . . . . . . . . . . 101

5.8 Elevação subinercial da superfície do mar modelada para passagem de fria fria média no inverno (experimento 2B), de acordo com os locais

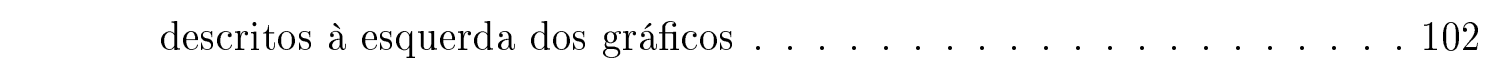

5.9 Elevação subinercial da superfície do mar modelada para passagem de frente fria média que não percorre toda a extensão da Plataforma \begin{tabular}{|c|}
\hline Continental Sudeste no verão (experimento 3A), de acordo com os \\
\hline
\end{tabular} locais descritos à esquerda dos gráficos. . . . . . . . . . . . . . . . 103

5.10 Elevação subinercial da superfície do mar para passagem de frente fria média que não percorre toda a extensão da Plataforma Conti\begin{tabular}{|c|}
\hline nental Sudeste no inverno (experimento 3B), de acordo com os locais \\
\hline
\end{tabular} - descritos à esquerda dos gráficos. . . . . . . . . . . . . . . . . 104

5.11 Isopletas de elevação do nível do mar (em $\mathrm{m}$ ) nos locais descritos no eixo vertical à esquerda, ao longo dos dias de simulação (eixo \begin{tabular}{|c|}
\hline horizontal) dos cenários de frente fria média e frente fria média que \\
\hline não percorre toda a extensão da Plataforma Continental Sudeste no \\
\hline verão (dois painéis superiores), e dos cenários de frente fria média \\
\hline e frente fria média que não percorre toda a Plataforma Continental \\
\hline Sta
\end{tabular} Sudeste no inverno (dois painéis inferiores). . . . . . . . . . 105 
5.12 Elevação máxima do nível do mar subinercial na costa para cada experimento com frente frias médias (cores) em cada um dos locais destacados no eixo horizontal. . . . . . . . . . . . . . . . 107

5.13 Correlação entre a variação do nível do mar em São Francisco do Sul (quadrado preto) com o restante do domínio, sendo mostrada

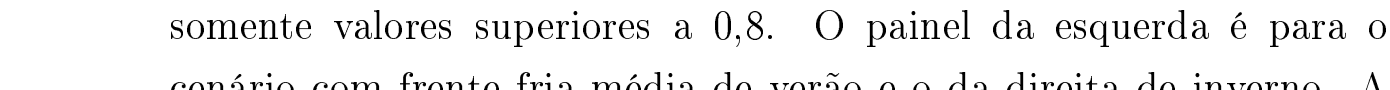
cenário com frente fria média de verão e o da direita de inverno. A correlação apresentada é a máxima obtida em todos os lags positivos, com confiabilidade estatística de 95\%. . . . . . . . . . . . . . 107

5.14 Correlação entre a variação do nível do mar em São Francisco do Sul (quadrado preto) com o restante do domínio, sendo mostrados somente valores superiores a 0,7. O painel da esquerda é para o cenário com frente fria média que não percorre toda a extensão da PCSE no verão e o da direita no inverno. A correlação apresentada é a máxima obtida em todos os lags positivos, com confiabilidade estatística de $95 \%$. . . . . . . . . . . . . . . 108

5.15 Elevação subinercial da superfície do mar desde a costa (esquerda nos painéis) até a quebra da PCSE (direita nos painéis) para passagem de FF média no verão (Experimento 2A), para os instantes descritos nos títulos dos painéis, e as radiais de acordo com a Figura $\mid 3.6$ | . . 110

5.16 Elevação subinercial da superfície do mar desde a costa (esquerda nos painéis) até a quebra da PCSE (direita nos painéis) para passagem de FF média no inverno (Experimento 2B), para os instantes descritos

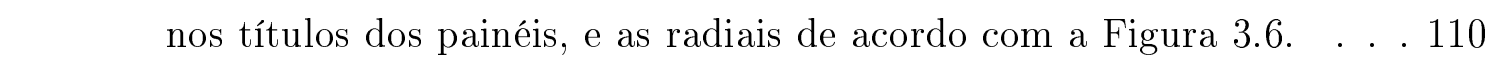

5.17 Elevação subinercial da superfície do mar desde a costa (esquerda nos painéis) até a quebra da PCSE (direita nos painéis) para passagem de FF média que não percorre toda a extensão da PCSE no verão (Experimento 3A), para os instantes descritos nos títulos dos painéis, e as radiais de acordo com a Figura 3.6 . . . . . . . . . . . . . . 111

5.18 Elevação subinercial da superfície do mar desde a costa (esquerda nos painéis) até a quebra da PCSE (direita nos painéis) para passagem de FF média que não percorre toda a extensão da PCSE no inverno \begin{tabular}{|c|}
\hline (Experimento 3B), para os instantes descritos nos títulos dos painéis, \\
\hline
\end{tabular} e as radiais de acordo com a Figura $\mid 3.6$. . . . . . . . . . . . . . . 111

5.19 Média temporal da energia potencial por unidade de área horizontal \begin{tabular}{|c|}
\hline$\left(J . m^{-2}\right)$ para os cenários de ventos reais de verão (esquerda, Experi- \\
\hline
\end{tabular} mento 1A) e de inverno (direita, Experimento 1B). . . . . . . . . 112 
5.20 Correlação entre a variação subinercial do nível do mar na costa e a componente do vento perpendicular à costa nos locais listados no eixo vertical. O eixo horizontal representa a defasagem (lags) calculados. O painel superior é para o cenário de ventos reais no verão (experimento 1A) e o inferior de ventos reais no inverno (experimento 1B). É mostrada somente correlação mínima com confiabilidade estatística

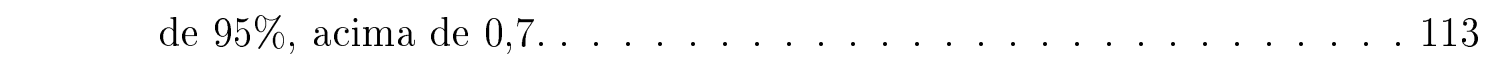

5.21 Correlação entre a variação subinercial do nível do mar na costa e a componente do vento paralela à costa nos locais listados no eixo vertical. O eixo horizontal representa a defasagem (lags) calculados. O painel superior é para o cenário de ventos reais no verão (experimento 1A) e o inferior de ventos reais no inverno (experimento 1B). É mostrada somente correlação mínima com confiabilidade estatística

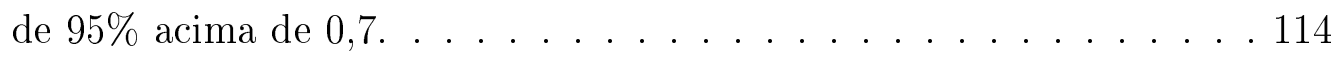

5.22 Correlação, para o período de verão, entre a variação subinercial da superfície livre do mar do local indicado pela linha horizontal preta e a componente do vento paralela à costa dos demais locais indicados no eixo vertical. O eixo horizontal indica o lag em dias. São apresentadas somente as correlações acima de 0,6 com confiabilidade estatística mínima de 95\% . . . . . . . . . . . . . . 116

5.23 Correlação, para o período de inverno, entre a variação subinercial da superfície livre do mar do local indicado pela linha horizontal preta e a componente do vento paralela à costa dos demais locais indicados no eixo vertical. O eixo horizontal indica o lag em dias. São apresentadas somente as correlações acima de 0,6 com confiabilidade estatística mínima de $95 \%$. . . . . . . . . . . . . . 117

5.24 Correlação, para o período de verão, entre a variação subinercial da superfície livre do mar do local indicado pela linha horizontal preta e a componente do vento perpendicular à costa dos demais locais indicados no eixo vertical. O eixo horizontal indica o lag em dias. São apresentadas somente as correlações acima de 0,6 com confiabilidade

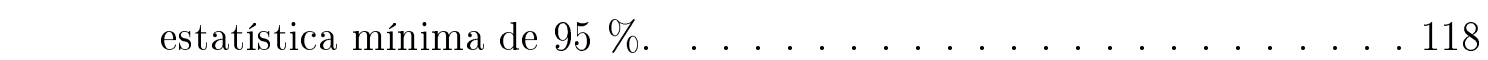

5.25 Correlação, para o período de inverno, entre a variação subinercial da superfície livre do mar do local indicado pela linha horizontal preta e a componente do vento perpendicular à costa dos demais locais indicados no eixo vertical. O eixo horizontal indica o lag em dias. São apresentadas somente as correlações acima de 0,6 com confiabilidade

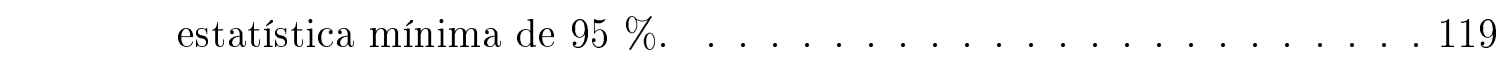


5.26 Séries de tempo de elevação subinercial da superfície livre do mar modelada (Experimento 1A - linha preta - sem vento e com forçante externa) e observada (linha vermelha) durante o verão de 2003. Os

locais representativos de cada série estão listados na lateral esquerda de cada painel. . . . . . . . . . . . . . . . . 121

5.27 Séries de tempo de elevação subinercial da superfície livre do mar modelada (Experimento 1A - linha preta - com vento e com forçante externa) e observada (linha vermelha) durante o verão de 2003. Os locais representativos de cada série estão listados na lateral esquerda de cada painel. . . . . . . . . . . . . . . . . 121

5.28 Isolinhas dos espectros de potência para a oscilação da superfície livre do mar para o verão de 2003, em função da distância ao longo da costa (ordenadas) e do período (abcissas), para o experimento 1A acrescido da forçante externa. São apresentadas as potências mínimas com confiabilidade estatística de $95 \%$ e 10,5 graus de liberdade. . . . . . . 123

5.29 Isolinhas que representam a diferença entre os espectros de potência do experimento 1A com e sem acréscimo de forçante externa, para a oscilação da superfície livre do mar para o verão de 2003 em função da distância ao longo da costa (ordenadas) e do período (abcissas). São apresentadas as potências mínimas com confiabilidade estatística de $95 \%$ e 10,5 graus de liberdade. . . . . . . . . . . . . . . . . . 123

5.30 Regiões de formação e propagação de OPC na PCSE. As setas indicam os ventos favoráveis para a formação de OPC na PCSE e o sentido de deslocamento destas após sua formação. . . . . . . . . . 126 


\section{Lista de Tabelas}

1.1 Propriedades termohalinas das massas de água da Plataforma Continental Sudeste. Fonte: Miranda $[(1982)$ e Castro $[1996)]$. . . . . . . 16

3.1 Propriedades dos dados provenientes de estações utilizados para va\begin{tabular}{|c|}
\hline lidar o banco de dados atmosférico (NCEP-DOE AMIP II) utilizado \\
\hline
\end{tabular} neste estudo. . . . . . . . . . . . . . . . . 31

3.2 Experimentos numéricos propostos para compor o BDO. VR representa vento real, VM vento médio, PFF passagem de frente fria e FFD passagem de frente fria que não percorre toda a extensão da PCSE. . . . . . . . . . . . . . . . . 39

3.3 Propriedades dos dados observados utilizados para validar o banco de dados oceânico utilizado neste estudo. . . . . . . . . . . . . . . 41

4.1 Estimativas estatísticas dos dados coletados em estações meteorológicas oceânicas (coletado) e do banco de dados atmosférico (NCEPDOE AMIP II). Per. é a componente do vento perpendicular à costa; \begin{tabular}{|c|}
\hline Par. é a componente do vento paralela à costa; Pressão atm. é a \\
\hline
\end{tabular} pressão atmosférica. . . . . . . . . . . . . . 51

4.2 Estimativas estatísticas dos dados coletados em estações meteorológicas costeiras (coletado) e do banco de dados atmosférico (NCEP-DOE AMIP II). Per. é a componente do vento perpendicular à costa; Par. é a componente do vento paralela à costa; Pressão atm. é a pressão atmosférica . . . . . . . . . . . . . . . 52

4.3 Correlação mínima com $95 \%$ de confiabilidade, skill e NRMS entre as séries coletadas por estações meteorológicas costeiras e oceânicas e o banco de dados atmosférico. Per. é a componente do vento perpendicular à costa; Par. é a componente do vento paralela à costa; Pressão atm. é a pressão atmosférica. . . . . . . . . . . . . . . 54

4.4 Estimativas estatísticas dos dados de elevação da superfície livre do mar coletados em marégrafos (coletado) e do banco de dados oceânico

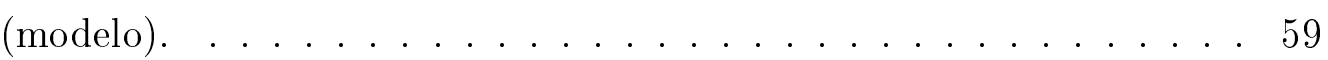


4.5 Correlação mínima com $95 \%$ de confiabilidade, skill e NRMS entre as séries coletadas por marégrafos e as modeladas nos Experimentos 1A (verão) e 1B (Inverno). Sub. significa subinercial. . . . . . . . . . 60

4.6 Estimativa estatísticas das FF identificadas em período de verão nos \begin{tabular}{|c|}
\hline pontos SUL (S), NORTE (N) e aquelas que não percorreram toda a \\
\hline
\end{tabular} extensão da PCSE (D). . . . . . . . . . . . . . 66 66

4.7 Estimativa estatísticas das FF identificadas em período de inverno nos \begin{tabular}{|c|}
\hline pontos SUL $(\mathrm{S})$, NORTE (N) e aquelas que não percorreram toda a \\
\hline
\end{tabular} extensão da PCSE (D). . . . . . . . . . . . . . 66 66

5.1 Parâmetros estatísticos comparativos entre o número de frentes frias identificadas em período de verão nos pontos SUL (S), NORTE (N)

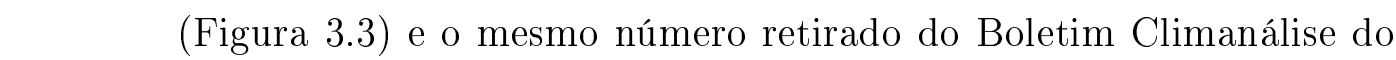
CPTEC/INPE. Total refere-se ao número total de frentes frias entre 1996 e 2011, Média é a média mensal para esses mesmos anos e Desvio

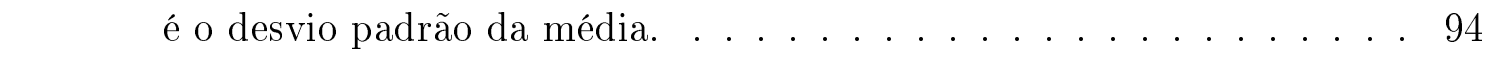

5.2 Parâmetros estatísticos comparativos entre o número de frentes frias identificadas em período de inverno nos pontos SUL (S), NORTE (N) \begin{tabular}{|r|r|r|}
\hline (Figura & $3.3)$ e o mesmo número retirado do Boletim Climanálise do \\
\hline \hline CPTEC
\end{tabular} CPTEC/INPE. Total refere-se ao número total de frentes frias entre 1996 e 2011, Média é a média mensal para esses mesmos anos e Desvio é o desvio padrão da média. . . . . . . . . . . . . . . . . . . . . . 94

5.3 Correlação mínima (95\% de confiabilidade), skill e NRMS entre as séries coletadas por marégrafos e as modeladas nos Experimentos 1A (V), 1A sem vento e com forçante externa (FE) e 1A com vento e forçante externa $(\mathrm{V}+\mathrm{FE}) . \ldots \ldots . \ldots . . \ldots 122$

5.4 Direção em graus do vento dominante que provoca perturbações no nível do mar na Plataforma Continental Sudeste. . . . . . . . . . . . . 124

5.5 Porcentagem da variância subinercial explicadas pelos eventos com períodos entre $3-5,7-9$ e $17-19$ dias. . . . . . . . . . . . . . . 125 


\section{Capítulo 1}

\section{Introdução}

A Plataforma Continental (PC) é uma feição fisiográfica que circunda os continentes, tendo topografia relativamente plana em direção ao oceano profundo, e sendo limitada por uma região de acentuada inclinação, denominada quebra da PC Coutinho 2005). Os processos dinâmicos na PC são influenciados por algumas características típicas: barreira imposta ao fluxo pela presença da costa, menores profundidades (assim o atrito de fundo é importante) e largura relativamente pequena quando comparada com a dimensão ao longo da costa.

Oscilações subinerciais (OS) ou submaregráficas (períodos de dias a semanas) nos campos de velocidade, elevação da superfície livre do mar, temperatura, salinidade e densidade são fenômenos típicos de PC. Essas oscilações são, na maior parte das vezes, geradas pelas variações sinóticas (também período de dias as semanas) da tensão de cisalhamento do vento. Em geral, quanto mais larga a PC e quanto mais energéticas as variações sinóticas do vento, maiores serão as amplitudes das OS na água do mar situadas nas regiões interna e média da PC, principalmente em latitudes médias.

As OS num ponto da PC são, na verdade, resposta das águas às variações sinóticas locais e remotas da tensão de cisalhamento do vento. Variações locais dos ventos, principalmente da componente quase paralela à costa, causam variações da componente quase perpendicular à costa do transporte de deriva do vento. A divergência desse transporte na costa força variações na elevação da superfície do mar e, consequentemente, na força do gradiente de pressão. Essa força, por sua vez, é responsável

pelas correntes geostróficas quase paralelas à costa, chamadas "jatos-costeiros" (Csanady 1977). Consequentemente, variações sinóticas da tensão de cisalhamento do vento ocasionam, algumas poucas dezenas de horas depois, ou num intervalo de tempo da ordem do período inercial local, OS nos campos hidrotermodinâmicos da água do mar.

Variações remotas dos ventos podem, através da geração de vorticidade relativa nas águas que se deslocam quase perpendicularmente à costa em continuidade ao 
transporte de deriva do vento, formando o "transporte de retorno", excitar ondas semi-geostróficas que se propagam ao longo da costa. Localmente, a passagem dessas ondas é observada na forma de OS que apresentam baixa correlação e coerência com o vento local.

Essas ondas semi-geostróficas, denominadas Ondas de Plataforma Continental (OPC) (Robinson 1964), são confinadas na PCS pela conservação da vorticidade potencial e apresentam comprimentos de onda maiores ou iguais a $1000 \mathrm{~km}$ e períodos subinerciais em latitudes médias (LeBlond \& Mysak 1977). Além disso, o balanço geostrófico entre a força do gradiente de pressão perpendicular à costa e a corrente paralela à costa faz com que OPC sejam unidirecionais, propagando-se com a costa à esquerda (direita) no hemisfério sul (norte).

A primeira observação do OPC foi efetuada por Hamon (1962) durante estudo na costa leste australiana, detectando um intervalo de tempo entre as variações do nível do mar correlacionadas entre duas estações separadas por $500 \mathrm{~km}$ ao longo da costa. Este fenômeno foi interpretado como uma onda de baixa frequência se propagando para o norte deixando a costa à esquerda. Este autor também observou que esse fenômeno era restrito à zona costeira, visto que em registros simultâneos realizados em uma estação afastada da costa não foi observada a presença de tal onda. Desde então, a partir de dados de elevação da superfície do mar e de correntes foram encontradas evidências da presença de OPC ao longo da costa do Peru (Romea \& Smith 1983, Brink 1982); da Austrália (Freeland et al. 1986, Eliot \& Pattiaratchi 2010); do México (Enfield \& Allen 1983, Martinez \& Allen 2004); de New Jersey (Hamon 1976, Yankovsky \& Garvine 1998), do Oregon (Cutchin \& Smith 1973. Kundu \& Allen 1976) e Washington (Battisti \& Hickey 1984); da África do Sul (Schumann \& Brink 1990, Schummann 1983); da China (Dake \& Jilan 1987); do Mar Mediterrâneo (Jordi et al. 2005); na costa leste da América do Sul (Jordi et al. 2005) e da Plataforma Continental Sudeste do Brasil (Castro 1985, Castro \& Lee 1995, Dottori \& Castro 2009, Rahy 2006, Campos et al. 2010).

Robinson (1964) propôs que as OPC poderiam ser formadas devido à variações espaciais e temporais no campo de pressão atmosférica. Hamon (1976) destacou a importância do campo de ventos associada à esta variação de pressão atmosférica. Adams \& Buchwald (1969) comprovaram que o atrito do vento é o maior responsável para a geração destas ondas e Gill \& Schumann (1974) mostraram que, mesmo com a presença da forçante tensão de cisalhamento do vento, as OPC não seriam produzidas se não houvesse inclinação de fundo, a costa, e a consequente geração de vorticidade relativa.

A explicação física do processo de geração das OPC é que a tensão do cisalhamento de vento paralelo à costa gera transporte perpendicular à costa na camada de Ekman superficial. Por continuidade, um fluxo compensatório no sentido oposto 
deste transporte ocorre em toda a coluna de água, com velocidades inclusive nas camadas mais profundas. Quando esse fluxo cruza as isóbatas, mudanças na vorticidade relativa local são geradas por estiramento do tubo de vórtice. Esta geração de OPC pode ser descritas inicialmente a partir das equações de águas rasas, linearizadas, no caso homogêneo ( $\bar{\rho}=$ constante, onde $\rho$ é a densidade):

$$
\begin{gathered}
\frac{\partial u}{\partial t}-f_{0} v=-g \frac{\partial \eta}{\partial x}-\frac{1}{\bar{\rho}} \frac{\partial P_{a}}{\partial x}+\frac{X_{s}}{H_{0}} \\
\frac{\partial v}{\partial t}+f_{0} u=-g \frac{\partial \eta}{\partial y}-\frac{1}{\bar{\rho}} \frac{\partial P_{a}}{\partial y}+\frac{Y_{s}}{H_{0}} \\
\frac{\partial \eta}{\partial t}+\frac{\partial}{\partial x}\left(H_{0} u\right)+\frac{\partial}{\partial y}\left(H_{0} v\right)=0
\end{gathered}
$$

onde $x$ e $y$ são as direções horizontais perpendicular e paralela à costa, respectivamente; $u$ e $v$ são as componentes de velocidade nas direções $x$ e $y$, respectivamente; $t$ é o tempo; $f_{0}$ é a frequência inercial, suposta constante; $g$ é a aceleração da gravidade; $\eta$ é a elevação da superfície do mar sobre o nível de repouso, situado em $z=0$, com eixo $z$ apontando para cima; $H_{0}$ é a profundidade local; $P_{a}$ é a pressão atmosférica e:

$$
\begin{aligned}
& X_{s}=\frac{\tau_{s x}}{\bar{\rho}} \\
& Y_{s}=\frac{\tau_{s y}}{\bar{\rho}}
\end{aligned}
$$

e $\tau_{s x}$ e $\tau_{s y}$ são as tensões de cisalhamento do vento de acordo com os eixos coordenados $x$ e $y$, respectivamente.

A Equação da Continuidade (1.3) pode ser simplificada quando:

$$
\frac{f_{0}^{2} L^{2}}{g \bar{H}}<<1
$$

onde $L$ é a largura da $\mathrm{PC}, \bar{H}$ é a profundidade média da $\mathrm{PC}$, resultando, segundo Gill \& Schumann (1974), em:

$$
\frac{\partial}{\partial x}\left(H_{0} u\right)+\frac{\partial}{\partial y}\left(H_{0} v\right)=0
$$

Combinando a Equaçãa 1.7 com as componentes horizontais da Equação do Movimento $1.1 \mathrm{e} 1.2$ chegamos a seguinte Equação da Vorticidade para $H_{0}=H_{0}(x)$, 
considerando que não há variação da topografia na direção paralela à costa:

$$
\frac{\partial}{\partial t}\left(\frac{\partial v}{\partial x}-\frac{\partial u}{\partial y}\right)-\frac{f_{0} u}{H_{0}} \frac{\partial H_{0}}{\partial x}=\underbrace{\frac{1}{H_{0}}\left(\frac{\partial Y_{s}}{\partial x}-\frac{\partial X_{s}}{\partial y}\right)}_{I}-\underbrace{\frac{1}{H_{0}^{2}}\left(Y_{s} \frac{\partial H_{0}}{\partial x}\right)}_{I I}
$$

Ainda segundo Gill \& Schumann (1974), a primeira parcela do segundo membro $(I)$, proporcional a tensão de cisalhamento do vento é menor do que a segunda parcela desse mesmo membro $(I I)$, proporcional ao produto entre a tensão de cisalhamento do vento paralela à costa e o gradiente topográfico perpendicular à costa. Esse fato comprova que o rotacional da tensão de cisalhamento do vento não é importante na geração da vorticidade relativa na PC em larga escala e, consequentemente, não é um mecanismo gerador de OPC. Além disso a ausência de $P_{A}$ na Equação 1.8 mostram que variações da pressão atmosférica não são eficientes pra a geração de OPC.

\section{1 Área de Estudo}

A área de estudo desta Tese de Doutorado é a Plataforma Continental Sudeste (PCSE), que é compreendida por dois acidentes geográficos costeiros: Cabo Frio (RJ) e Cabo de Santa Marta (SC) (Figura 1.1), margeando a costa sudeste brasileira em aproximadamente $1.100 \mathrm{~km}$. A porção central da PCSE possui a maior largura, com aproximadamente $230 \mathrm{~km}$, e os extremos norte e sul as partes mais estreitas (50 e $70 \mathrm{~km}$, respectivamente), totalizando uma área de cerca de $150.000 \mathrm{~km}^{2}$ (Zembruski 1979). A profundidade da PCSE varia desde $0 \mathrm{~m}$ até aproximadamente $200 \mathrm{~m}$ (com a profundidade da quebra da PC variando desde $120 \mathrm{~m}$ ), com as isobatimétricas apresentando direção quase paralela à costa.

Além das características termohalinas e hidrodinâmicas intrínsecas à PCSE, os ventos sazonais (escala temporal anual) e sinóticos forçam movimentos energéticos por toda a largura da PCSE. Assim, sequencialmente, apresentamos a descrição da meteorologia sobre a PCSE e suas principais características termohalinas e hidrodinâmicas, relevantes para o trabalho apresentado nesta Tese de Doutorado. 

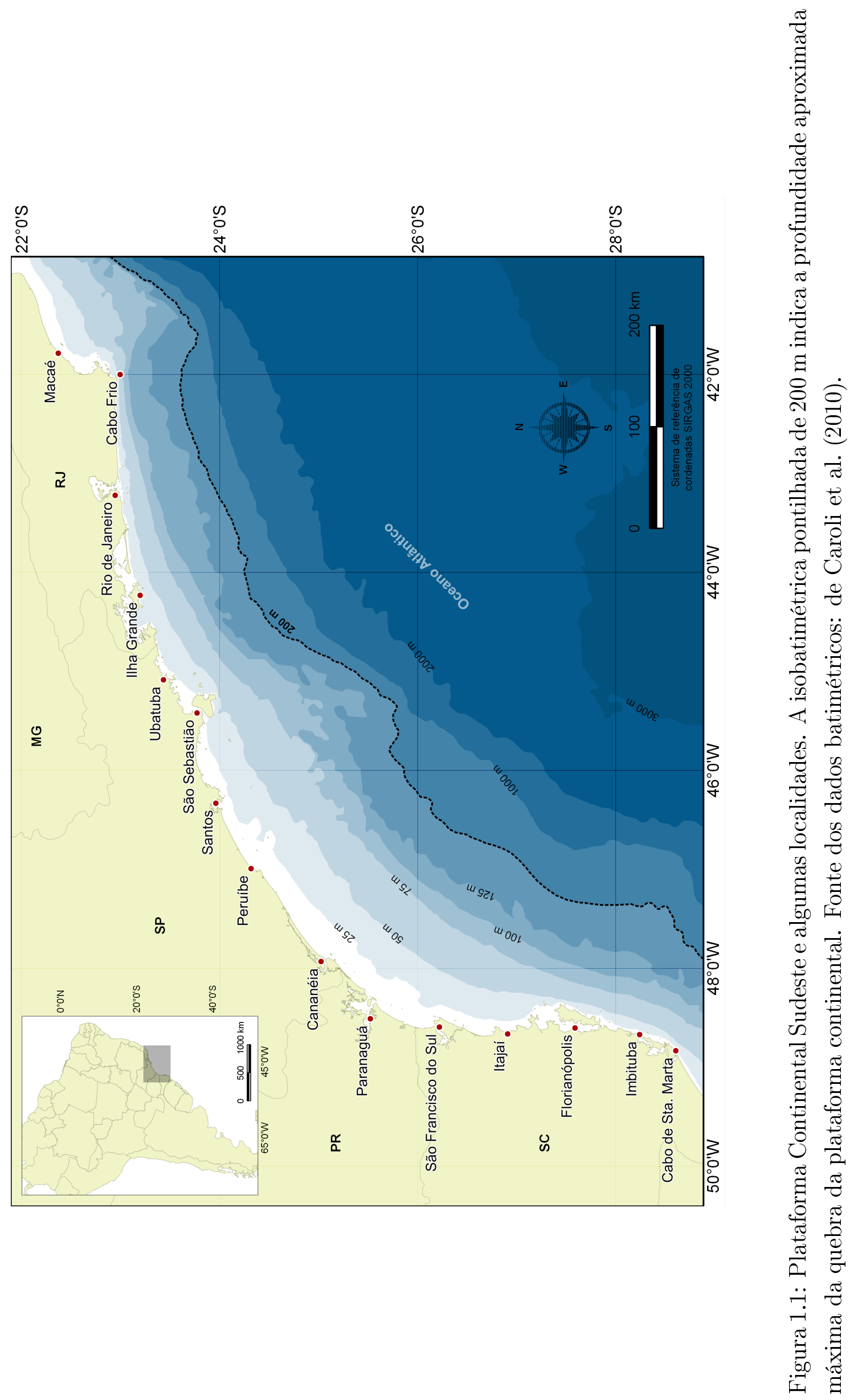


\subsubsection{A meteorologia sobre a Plataforma Continental Sudeste}

A meteorologia na área de estudo é influenciada pela presença de dois sistemas de macroescala: o Anticiclone Subtropical do Atlântico Sul (ASAS) e o Anticiclone Subtropical do Pacífico Sul - ASPS. O primeiro atua diretamente sobre a PCSE. Esses sistemas de alta pressão são corresponsáveis por parte das condições de tempo sobre o continente sul-americano, pois do posicionamento deles dependem as penetrações de massas de ar provenientes do sul e as gerações de sistemas de mesoescala continentais (Varejão-Silva 2006). Nas Figuras 1.2 e 1.3 são apresentados os posicionamentos dos referidos anticiclones nos meses de janeiro e julho, sendo estes meses representativos das estações verão e inverno, respectivamente. Estas figuras foram confeccionadas com dados de pressão atmosférica da Reanálise NCEP-DOE AMIP II (Kanamitsua et al. 2002), do período entre 1968 e 1996.

O ASAS apresenta variação de posicionamento entre o verão e o inverno: no mês de janeiro, seu centro encontra-se posicionado mais próximo ao continente africano e no mês de julho mais próximo ao continente sul-americano. Assim, o ASAS está mais distante da PCSE nos meses de verão e mais próximo nos meses de inverno. Na PCSE, portanto, os ventos de macroescala têm origem nordeste-leste, e as maiores pressões ocorrem nos meses de inverno. Estas condições padrão de tempo sofrem influências de perturbações ondulatórias que modificam as condições meteorológicas na PCSE. Dentre tais perturbações destacam-se: frentes (frias, quentes e estacionárias), ciclones extratropicais e anticiclones polares. Castro (1996) menciona que as frentes frias $(\mathrm{FF})$ são as principais perturbações meteorológicas que influenciam a hidrodinâmica sobre a PCSE.

As FF que afetam a PCSE são geradas em altas latitudes e se caracterizam por movimentos no sentido polo-equador (sul para norte), embora também existam deslocamentos oeste-leste que promovem uma trajetória final predominante sudoeste-nordeste, com pequenas variações sazonais em torno dessa trajetória. No verão, as FF deslocam-se predominantemente de sul-sudoeste para norte-nordeste. No inverno, seus deslocamentos tendem a ser de oeste-sudoeste para leste-nordeste (Rodrigues et al. 2004).

Na situação em que a massa de ar frio não consegue avançar sobre a massa de ar quente, surge a frente estacionária. A precipitação associada a este sistema é geralmente fraca e de origem estratiforme. Durante o verão as FF podem se manter sobre a área de estudo devido à presença de vórtices ciclônicos em altos níveis, na região nordeste do Brasil (Varejão-Silva 2006). 


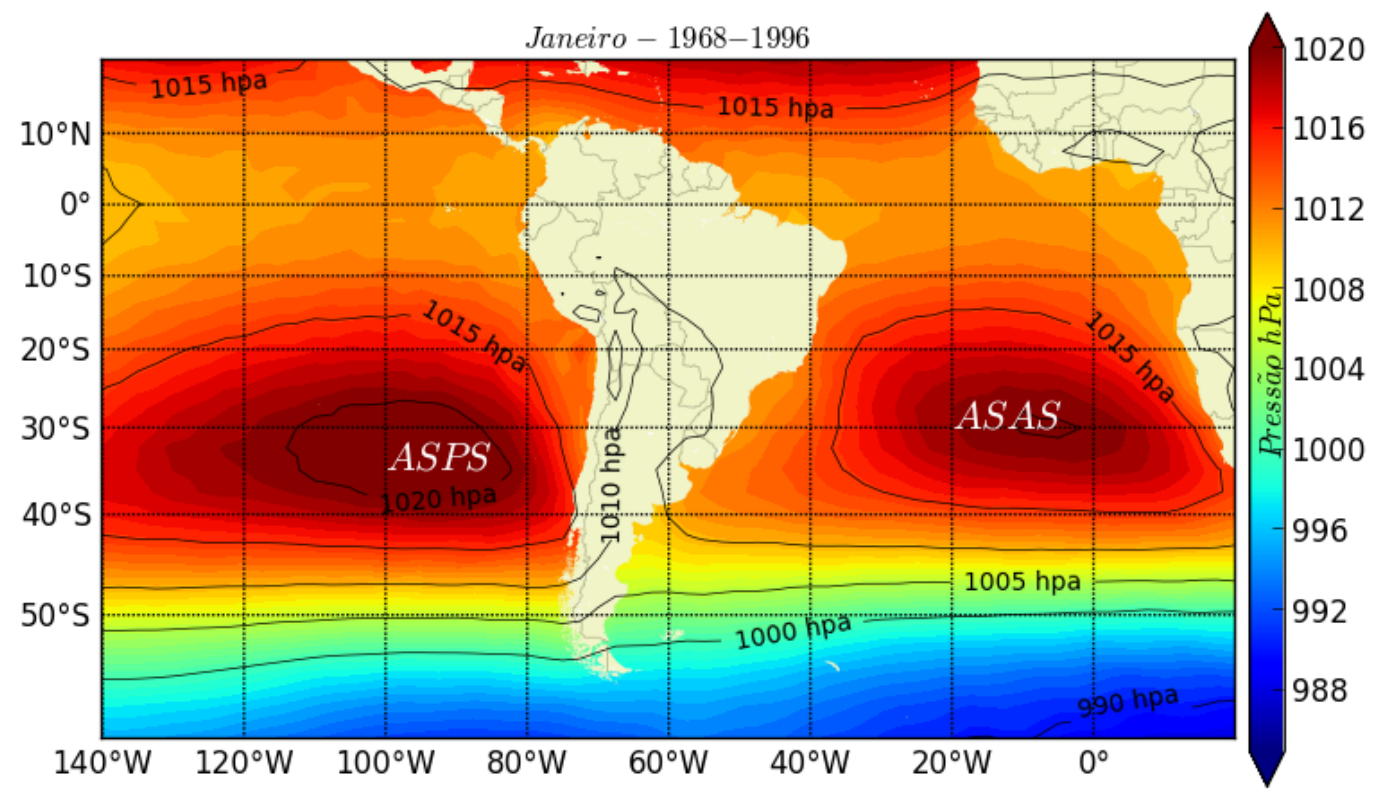

Figura 1.2: Pressão atmosférica indicando o posicionamento dos sistemas Anticiclone Subtropical do Pacífico Sul (ASPS) e do Anticiclone Subtropical do Atlântico Sul (ASAS) no verão. Fonte de dados: Reanálise NCEP-DOE AMIP II (Kanamitsua et al. 2002).

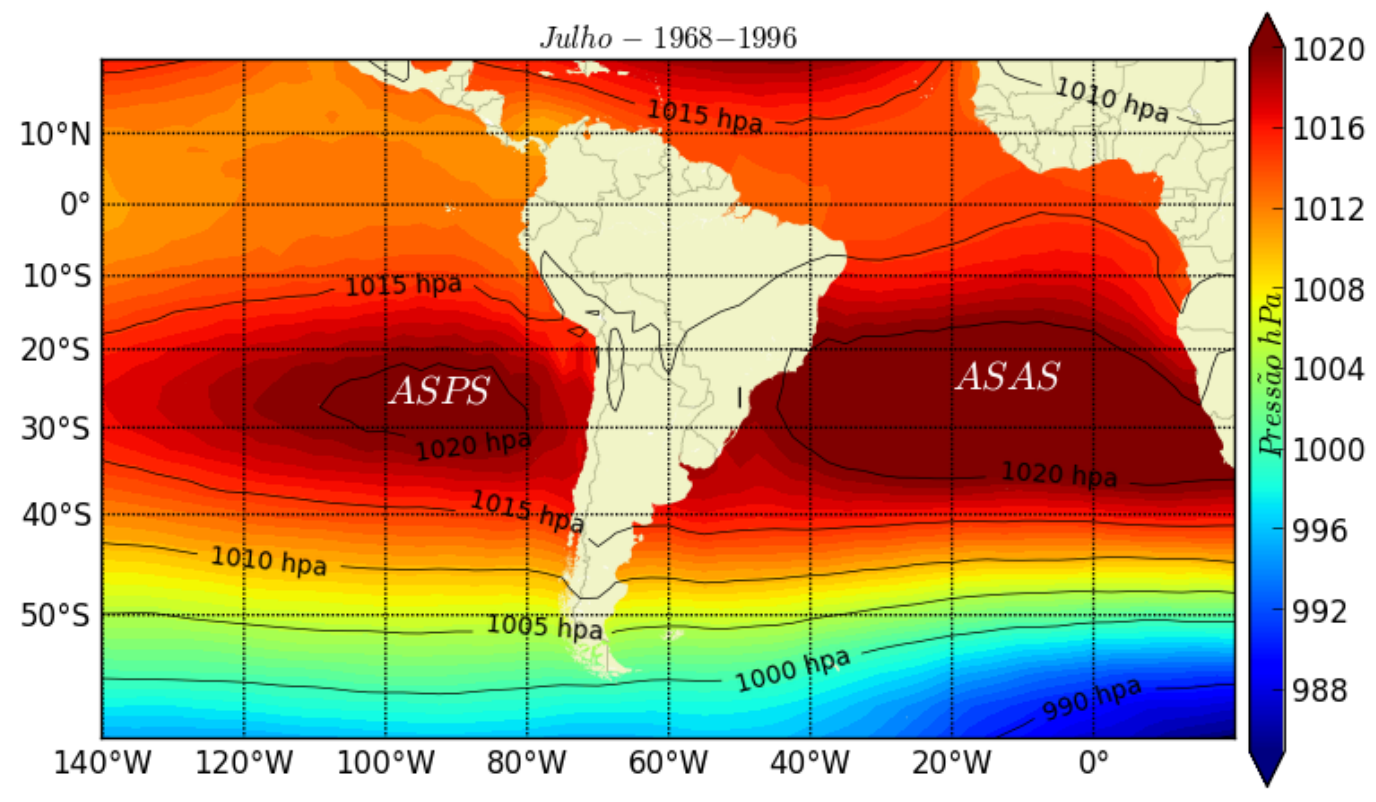

Figura 1.3: Pressão atmosférica indicando o posicionamento dos sistemas Anticiclone Subtropical do Pacífico Sul (ASPS) e do Anticiclone Subtropical do Atlântico Sul (ASAS) no inverno. Fonte de dados: Reanálise NCEP-DOE AMIP II (Kanamitsua et al. 2002). 
Para exemplificar as variações atmosféricas devido à passagem de uma FF sobre a PCSE são apresentadas as Figuras 1.4 a 1.6, que mostram imagens de satélite para o período entre 18/08/2011 e 24/08/2011, campos de pressão atmosférica e ventos a $10 \mathrm{~m}$ para o mesmo período provenientes da reanálise do NCEP-DOE AMIP II (Kanamitsua et al. 2002), e variação do vento a $10 \mathrm{~m}$, pressão atmosférica e temperatura atmosférica nas porções sul, central e norte da PCSE. Nas imagens de satélite da Figura 1.4 a FF pode ser identificada pela faixa de nuvens orientada no sentido sudeste-noroeste próxima à PCSE. Nestas figuras, o painel (a), que é representativo do dia 18/08/2011, mostra extensa faixa de nuvens cobrindo a região sul-sudeste do Brasil. Na Figura 1.5, no dia 18/08/2011, os ventos na região sul-sudeste do Brasil foram de origem nordeste-leste e um centro de baixa pressão atmosférica esteve presente ao sul desta região. A Figura 1.6 mostra que neste dia os ventos em todas as porções da PCSE foram de origem nordeste, com pressão atmosférica em declínio e temperatura estável. Nos dias subsequentes, as imagens de satélite da Figura 1.4 mostram o avanço da estrutura de nuvem em direção nordeste, e a Figura 1.5 mostra o avanço do centro de baixa pressão atmosférica sobre a região da PCSE e alteração do campo de ventos de nordeste-leste para sul-sudoeste. Esse aspecto é melhor verificado em todas as porções da PCSE na Figura 1.6, onde é clara a inversão dos vento. A pressão atmosférica atingiu seu mínimo no dia anterior à mudança do vento e, após, sofreu gradativo aumento. A temperatura atmosférica entrou em declínio juntamente com a inversão dos ventos. Após a entrada da FF sobre a PCSE, as imagens de satélite (Figura 1.4b a 1.4f) mostram que as nuvens se dissiparam ao norte da área de estudo e a Figura 1.5, para os mesmos dias, mostra que toda a região foi ocupada por um centro de alta pressão atmosférica, com ventos mudando gradativamente de sul/sudoeste para nordeste/leste. Na Figura 1.6 é possível perceber que toda a PCSE sofreu influência de ventos do quadrante sul por aproximadamente 4 dias, a partir de 19/08/2011, e após este período, a pressão atmosférica retornou à valores próximos aos iniciais. A temperatura atmosférica durante a passagem da $\mathrm{FF}$ sofreu maior variação na porção sul da PCSE (amplitude de $6^{\circ}$ Caproximadamente), com declínio concomitante com a alteração dos padrões de ventos. A porção norte da PCSE sofreu uma variação térmica de aproximadamente $4^{\circ} \mathrm{Cdurante}$ a passagem da FF.

Para exemplificar a passagem de uma FF que não percorre toda a PCSE são apresentadas as Figuras 1.7 a 1.9. A primeira mostra imagens de satélite para o período entre 01/02/2011 e 05/02/2011, a segunda campos de pressão atmosférica e ventos a $10 \mathrm{~m}$ para o mesmo período, provenientes da reanálise do NCEP-DOE AMIP II (Kanamitsua et al. 2002), e a terceira apresenta a variação do vento à 10 $\mathrm{m}$, pressão atmosférica e temperatura atmosférica nas porções sul, central e norte da PCSE. 

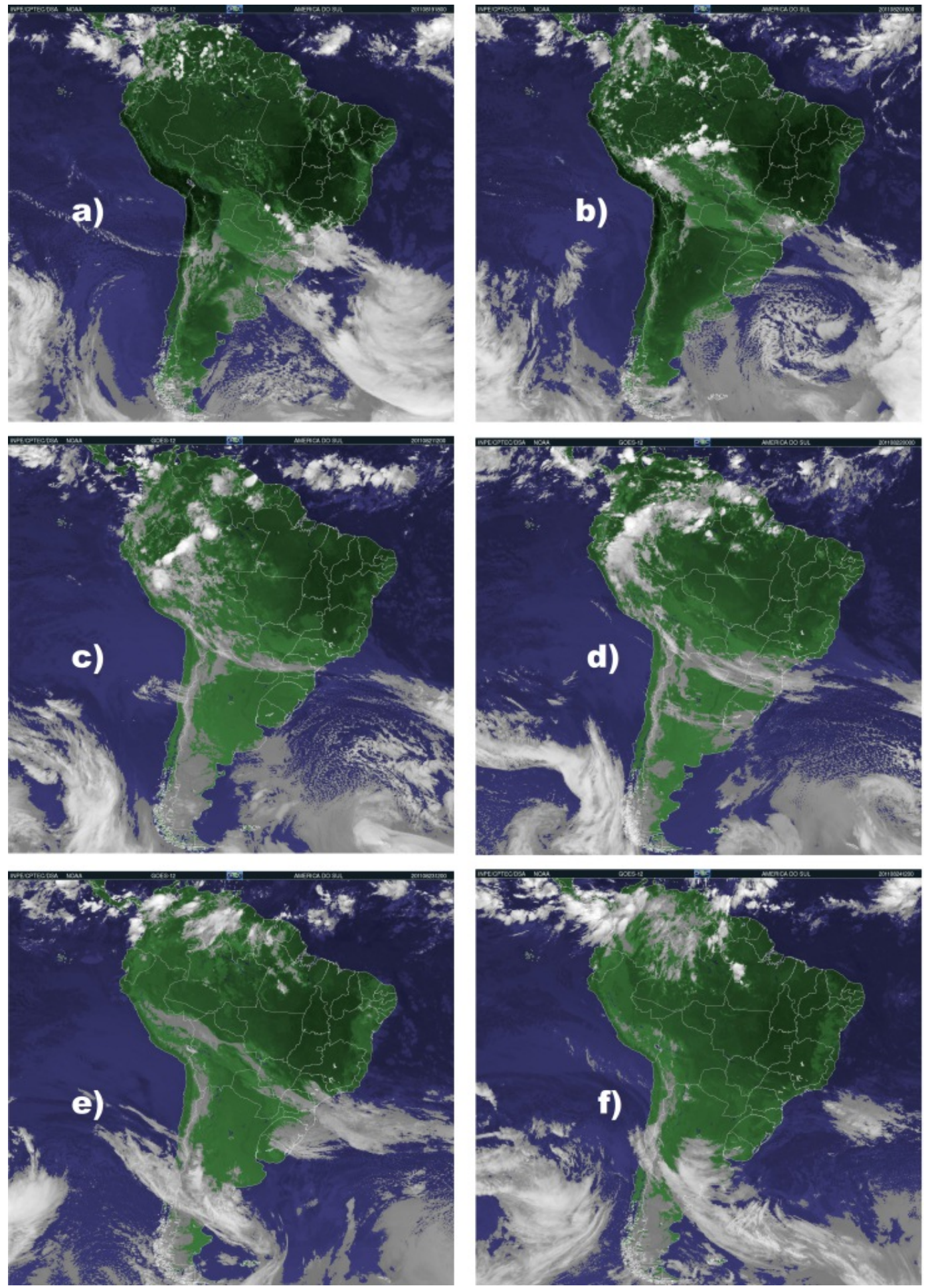

Figura 1.4: Imagens de satélite na banda do visível exemplificando uma frente fria que percorreu toda a Plataforma Continental Sudeste. O painel (a) é referente ao dia 18/08/2011, o (b) ao dia 19/08/2011, (c) 20/08/2011, (d) 21/08/2011, (e) 23/08/2011 e (f) 24/08/2011. Fonte: CPTEC/INPE. 

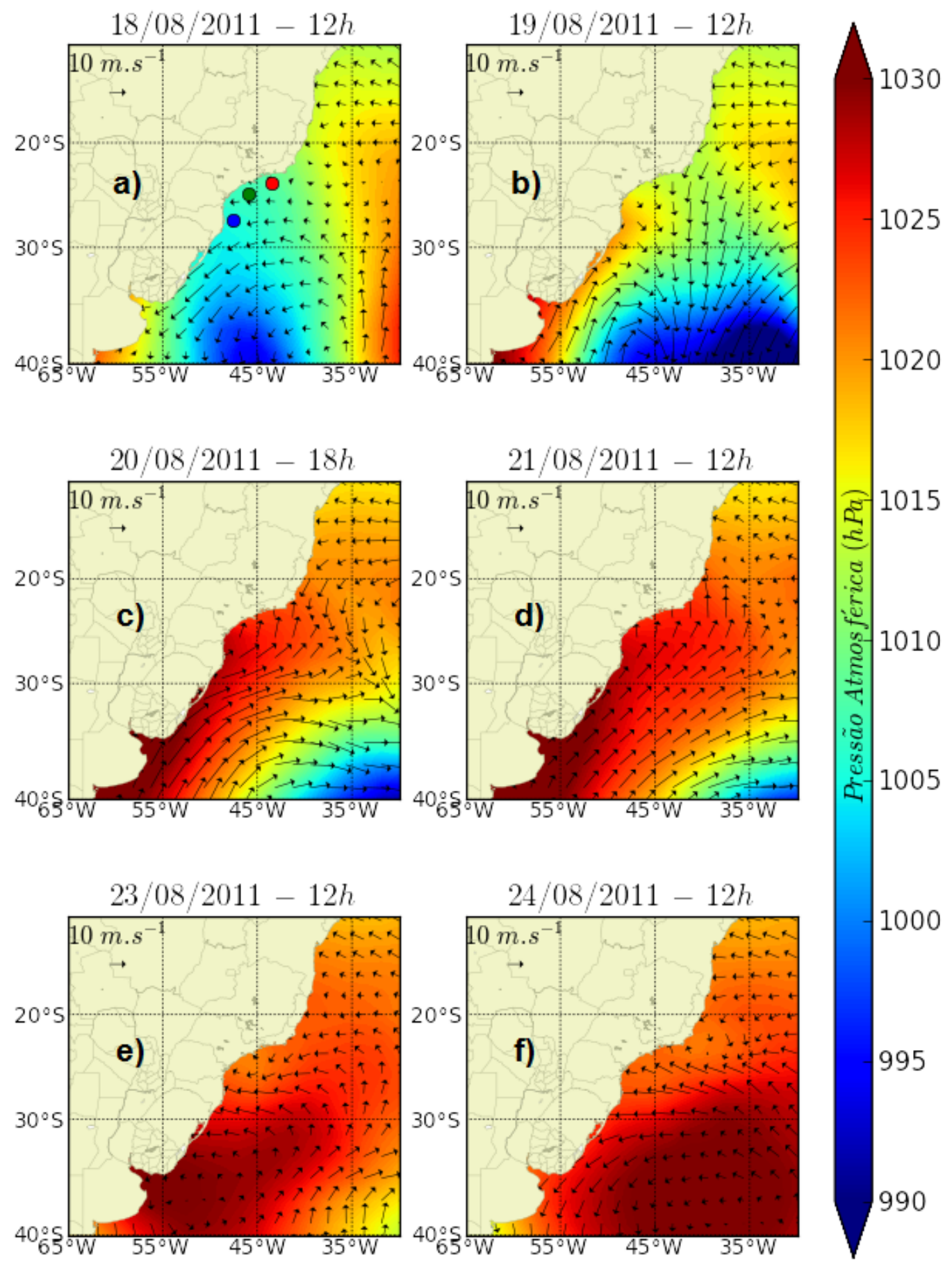

Figura 1.5: Pressão atmosférica (hPa - cores) e vento à $10 \mathrm{~m}$ (vetores) de um exemplo de uma frente fria sobre a Plataforma Continental Sudeste. O painel (a) é referente ao dia 18/08/2011, o (b) ao dia 19/08/2011, (c) 20/08/2011, (d) 21/08/2011, (e) $23 / 08 / 2011$ e (f) $24 / 08 / 2011$. Os três pontos no painel (a) referem-se a posições utilizadas na Figura 1.6. Fonte de dados: Reanálise NCEP-DOE AMIP II (Kanamitsua et al. 2002). 

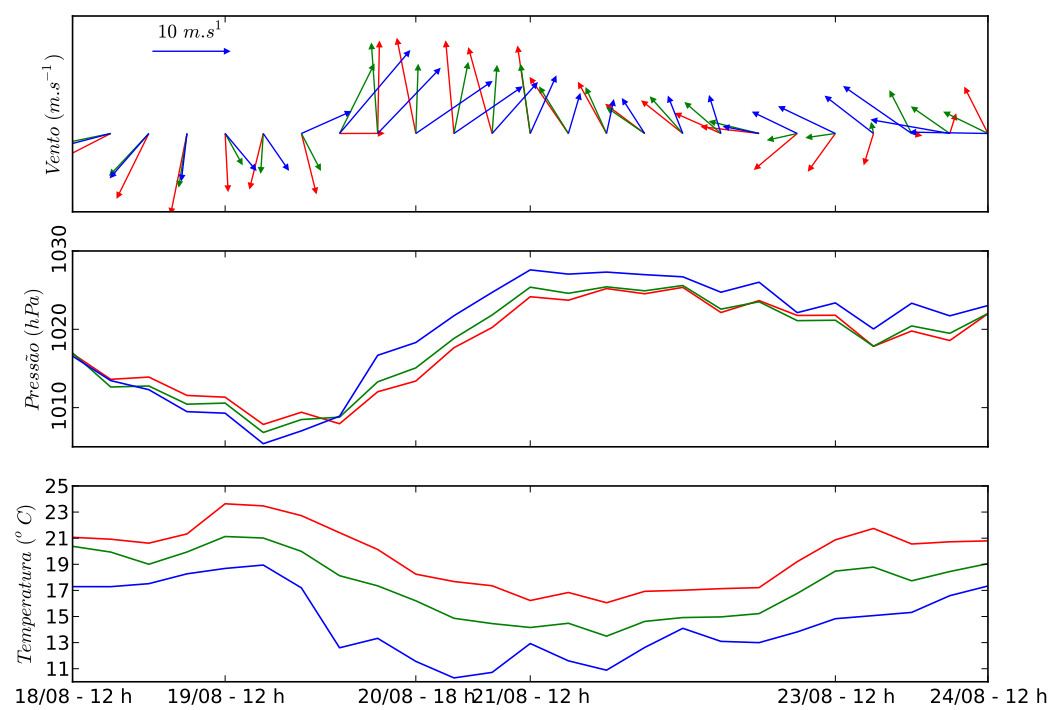

Figura 1.6: Variação do vento à $10 \mathrm{~m}$ (painel superior), pressão atmosférica (painel central) e temperatura superficial (painel inferior) de um exemplo de frente fria sobre a Plataforma Continental Sudeste. As cores de cada linha representam séries nos pontos de mesma cor apresentados no painel superior esquerdo da Figura 1.5. Fonte de dados: Reanálise NCEP-DOE AMIP II (Kanamitsua et al.|2002).

Como no exemplo anterior, nas imagens de satélite da Figura 1.7 a FF pode ser identificada pela faixa de nuvens orientada no sentido sudeste-noroeste próxima à área de estudo. Nestas imagens é possível identificar que a banda de nuvens se deslocou desde a região sul do Brasil e não percorreu toda a extensão da PCSE, deslocando-se para o largo. Este deslocamento é mais evidente na Figura 1.8, onde é possível identificar a variação espacial da área de baixa pressão atmosférica, que atingiu a região da PCSE no dia 01/02/2011 (painel b). Esta banda de baixa pressão ficou retida sobre a PCSE até aproximadamente o dia 03/02/2011 (painel d), e nos dias subsequentes o campo de pressão e ventos retornaram aos padrões iniciais. Ventos provenientes de sul atingiram a porção sul e central da PCSE durante o período de deslocamento do centro de baixa pressão. Sobre a PCSE, a Figura 1.9 mostra que apenas nas porções sul e central os ventos giraram devido à passagem da FF. As porções central e sul sofreram ação de ventos de sul-sudoeste por aproximadamente 2,5 dias e, após este período, toda a PCSE é dominada novamente por ventos de nordeste. A pressão e a temperatura atmosféricas são alteradas de forma significativa da PCSE. Nas porções central e norte a temperatura atmosférica praticamente se mantém inalterada no período de propagação da FF na porção sul da PCSE. Na porção sul o giro do vento marca as alterações da temperatura atmosférica: um 
dia anterior ao giro ocorre aumento e, a partir do momento do giro, declínio. A amplitude térmica total é de cerca de $4^{\circ} \mathrm{C}$ durante a passagem da FF.

Stech \& Lorenzzetti (1992) elaboraram um modelo conceitual de passagem de FF sobre a PCSE (Figura 1.10) baseando-se em cartas meteorológicas sinóticas e imagens termais do satélite GOES. Segundo os autores, o deslocamento típico da FF é de sudoeste para nordeste, com velocidade aproximada de $500 \mathrm{~km} /$ dia. No setor quente os ventos têm intensidade média de $5 \mathrm{~m} / \mathrm{s}$, giram de nordeste para noroeste com a aproximação da FF e, no setor frio, os ventos têm intensidade média de $8 \mathrm{~m} / \mathrm{s}$ e direção predominante de sudoeste, com rotação em sentido anti-horário, mudando para direção sudeste cerca de $24 \mathrm{~h}$ após a passagem da FF.

Um modelo mais recente e com maior detalhamento das características transientes da passagem de FF sobre a PCSE foi proposto por Coelho (2007). O autor analisou cartas sinóticas do período entre 1998 e 2005, identificando FF que percorreram toda a PCSE. Foram selecionadas 12 FF e suas velocidades de propagação calculadas admitindo-se uma propagação linear de sudoeste para nordeste. O autor concluiu que a velocidade média de propagação das FF é mais rápida no verão do que no inverno $(782,2 \mathrm{~km} /$ dia para a primeira). 

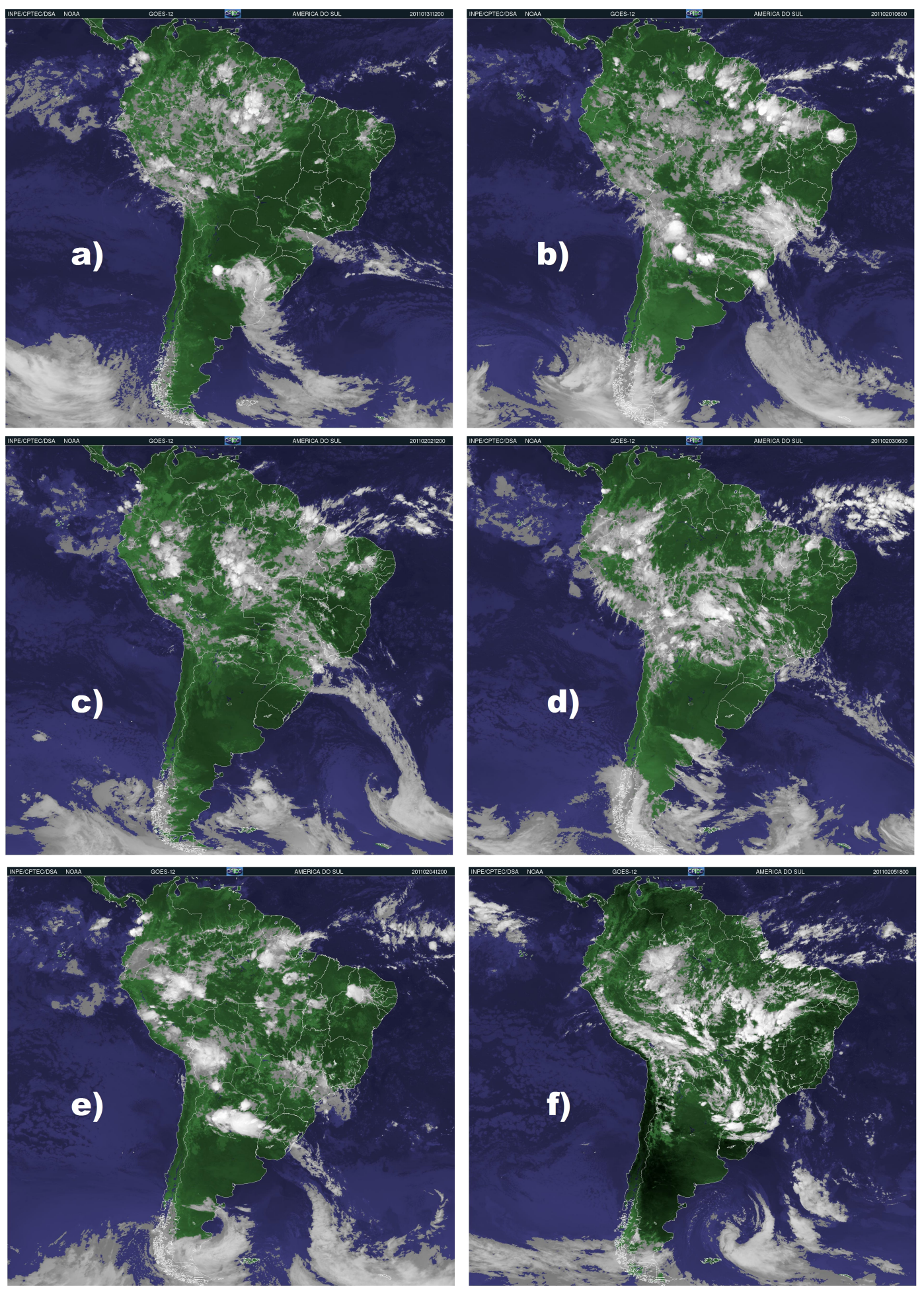

Figura 1.7: Imagens de satélite na banda do visível exemplificando uma frente fria que não percorreu toda a extensão da PCSE. O painel (a) é referente ao dia 31/01/2011, o (b) ao dia 01/02/2011, (c) 02/02/2011, (d) 03/02/2011, (e) 04/02/2011 e (f) 05/02/2011. Fonte: CPTEC/INPE. 

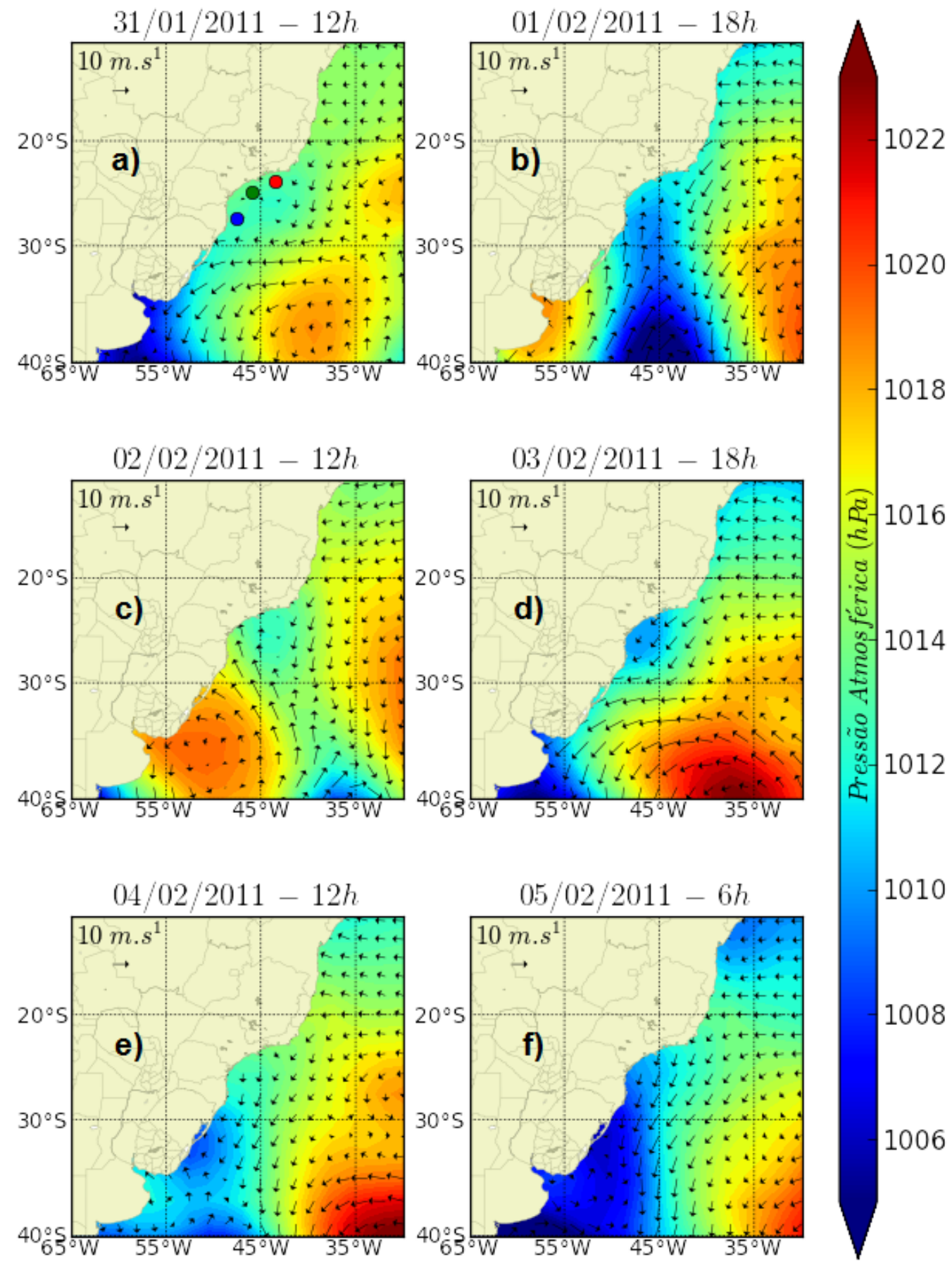

Figura 1.8: Pressão atmosférica (hPa - cores) e vento à $10 \mathrm{~m}$ (vetores) de um exemplo de frente fria que não percorreu toda a extensão da PCSE. O painel (a) é referente ao dia 31/01/2011, o (b) ao dia 01/02/2011, (c) 02/02/2011, (d) 03/02/2011, (e) 04/02/2011 e (f) 05/02/2011. Os três pontos no painel (a) referem-se a posições utilizadas na 1.9. Fonte de dados: Reanálise NCEP-DOE AMIP II (Kanamitsua et al. 2002). 

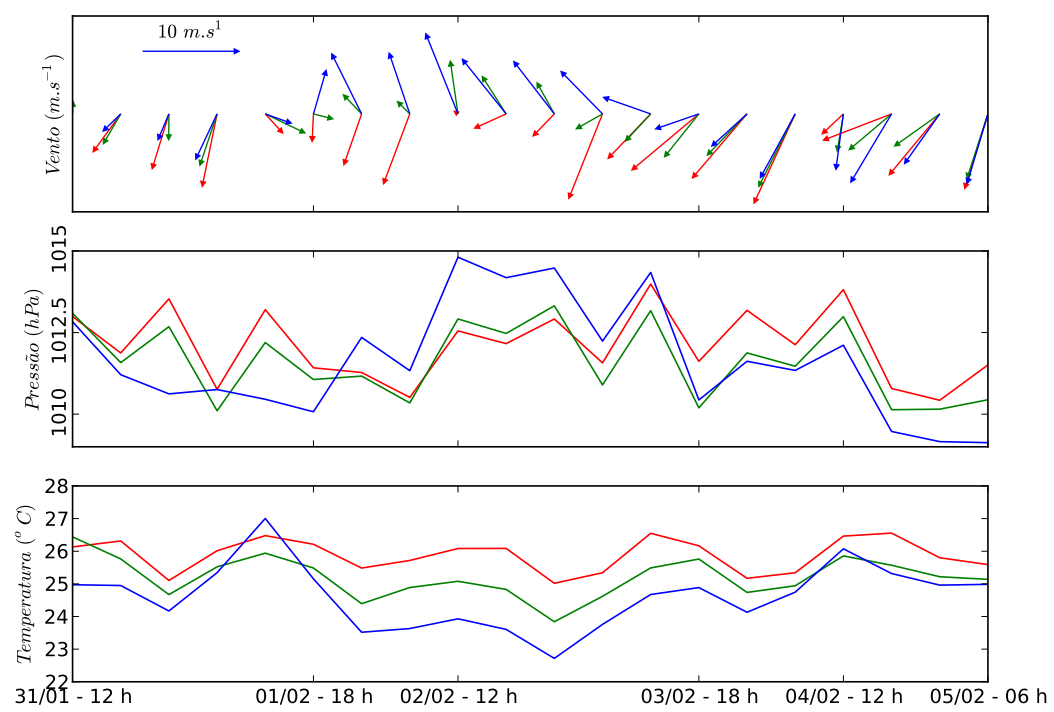

Figura 1.9: Variação do vento à $10 \mathrm{~m}$ (painel superior), pressão atmosférica (painel central) e temperatura superficial (painel inferior) de um exemplo de frente fria que não percorreu toda a extensão da PCSE. As cores de cada linha representam séries nos pontos de mesma cor apresentados no painel superior esquerdo da Figura 1.8 . Fonte de dados: Reanálise NCEP-DOE AMIP II (Kanamitsua et al. 2002).

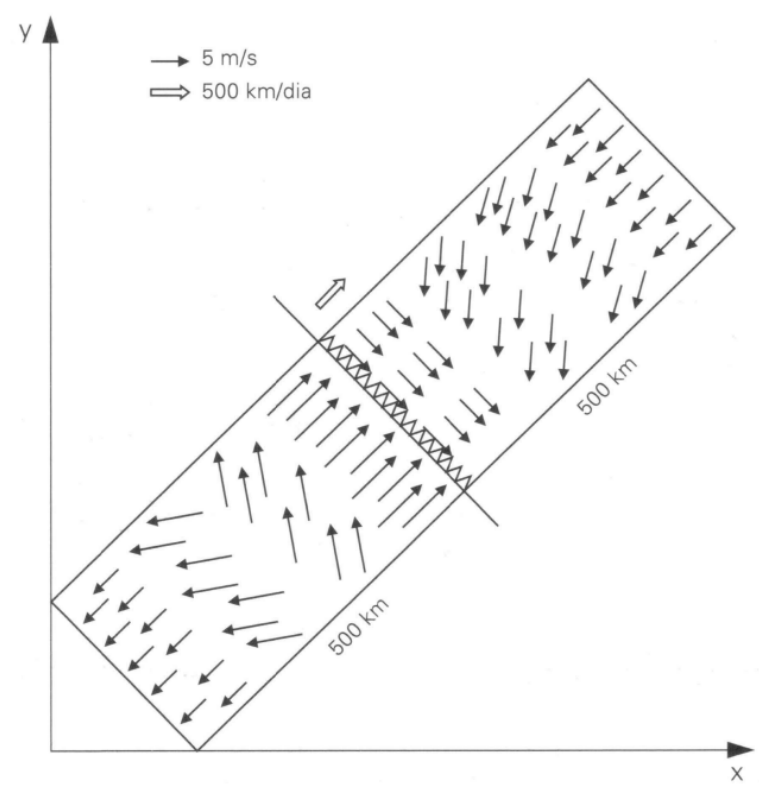

Figura 1.10: Modelo conceitual de passagem de frente fria sobre a Plataforma Continental Sudeste para o inverno, de acordo com Stech \& Lorenzzetti (1992) 


\subsubsection{A hidrografia da Plataforma Continental Sudeste}

A PCSE pode ser compartimentada a partir de critérios dinâmicos definidos por Castro (1996) para a região norte de SP. Tais critérios foram estendidos para toda a

PCSE por Rezende (2003) para o período de verão. As regiões definidas por Castro (1996) são:

- Plataforma Continental Interna (PCI): localizada entre a costa e a Frente Térmica Profunda (FTP), que é a região de separação entre águas com forte influência das massas de água Água Costeira (AC) e Água Central do Atlântico Sul (ACAS). A localização da FTP, durante o verão, está entre 10-30 km da costa, sobre as isóbatas de 20-40 m. No inverno, esta frente se localiza a 40-80 $\mathrm{km}$ da costa, sobre as isóbatas de 50-70 m;

- Plataforma Continental Média (PCM): localiza-se entre a FTP e a Frente Halina Superficial (FHS), que é a separação entre águas com forte influência das massas de água AC e Água Tropical (AT). No verão, estende-se deste 10$30 \mathrm{~km}$ da costa até $60-80 \mathrm{~km}$, sobre as isóbatas de 20-40 m e 70-90 m. No inverno, ocupa a faixa entre 40-60 km e 60-80 km da costa;

- Plataforma Continental Externa (PCE): estende-se desde a FHS até a quebra da PC.

Trabalhos anteriores como de Emilson (1962), Miranda (1982), Miranda (1985), Castro et al. (1987) e Miranda \& Katsuragawa (1991), estabeleceram que as massas de água que ocupam a PCSE são resultantes da mistura entre AT, ACAS e AC. A AT e ACAS apresentam índices termohalinos bem definidos (Tabela 1.1), diferente da AC, que é caracterizada por baixas salinidades, sendo resultado da mistura da descarga continental com as demais águas da PCSE.

Tabela 1.1: Propriedades termohalinas das massas de água da Plataforma Continental Sudeste. Fonte: Miranda (1982) e Castro (1996)

\begin{tabular}{c|c|c} 
Massa de Água & Temperatura & Salinidade \\
\hline ACAS & $6<\mathrm{T}<20$ & $34,6<\mathrm{S}<36,0$ \\
AT & $\mathrm{T}>20$ & $\mathrm{~S}>36,4$
\end{tabular}

Rezende (2003) apresentou a mais completa climatologia de massas de água para a PCSE, para o período de verão. A Figura 1.11 mostra o diagrama T-S destacando a presença das massas de água AT e ACAS na PCSE. Rezende (2003) apresentou ainda a distribuição horizontal e vertical média das propriedades temperatura e salinidade para toda a PCSE nos meses de verão (Figuras 1.13 e 1.12). As distribuições médias de temperatura apresentadas por Rezende (2003) mostram que 
sobre a PCSE, em superfície, a temperatura média apresenta valores superiores a $27^{\circ} \mathrm{Cem}$ duas regiões: ao largo da porção da PCSE compreendida entre os Cabos de São Tomé e Frio; e em seu centro, próximo a Santos e São Sebastião. Mínimos de temperatura são observados nas proximidades dos Cabos Frio $\left(19,6^{\circ} \mathrm{C}\right)$ e de Imbituba $\left(24,5^{\circ} \mathrm{C}\right)$, sinalizando, respectivamente, as influências do afloramento da ACAS e da presença de águas provenientes do sul do Brasil. A área sob influência do afloramento da ACAS na superfície estende-se até as proximidades da Ilha de São Sebastião, e nela são observados os maiores valores de gradiente horizontal de temperatura (aproximadamente $1^{\circ} \mathrm{C} / 10 \mathrm{~km}$, em Cabo Frio). Nos níveis inferiores se observa a tendência das isotermas se alinharem com as isobatimétricas. A distribuição da temperatura média de verão sobre o fundo da PCSE revela a presença de fortes gradientes horizontais em sua porção interna, até as imediações da isobatimétrica de $40 \mathrm{~m}$.

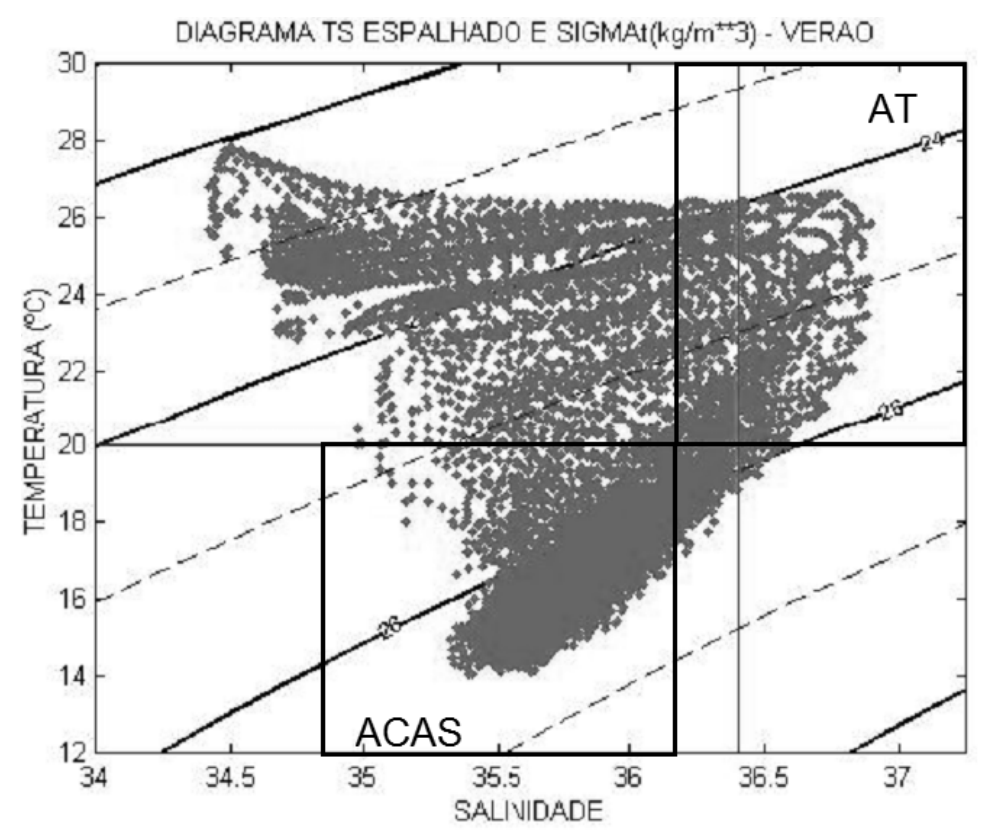

Figura 1.11: Diagrama T-S de verão para a Plataforma Continental Sudeste a partir de dados históricos observacionais. ACAS: Água Central do Atlântico Sul; AT: Água Tropical. Fonte: adaptado de Rezende 2003)

Sobre a salinidade, Rezende (2003) concluiu que a porção central costeira da PCSE apresenta águas superficiais menos salinas. No trecho compreendido entre Cananéia e São Sebastião os valores de salinidade média são inferiores a 34,5, aumentando em direção à quebra da PCSE. Nas imediações da isobatimétrica de 100 m, a salinidade média é da ordem de 36,0. As isohalinas acompanham, em geral, a configuração das isobatimétricas, muito embora a região norte da PCSE se apresente mais salina $(35,4$ a 36,2$)$ do que sua região sul $(34,7$ a 36,0), talvez devido à ação 
de águas mais frias e menos salinas provenientes do sul do Brasil. Os maiores gradientes horizontais de salinidade superficial ocorrem nas imediações da isobatimétrica de 100 m, sendo mais intensos das imediações de São Sebastião para o sul (cerca de $0,3 / 10 \mathrm{~km})$ do que na região norte.

Para o período de inverno os trabalhos climatológicos são mais escassos, destacando-se Castro \& Miranda (1998) que apresentaram distribuição superficial de temperatura e salinidade para esta estação (Figura 1.14 e Figura 1.15). Comparativamente ao período de verão, estas figuras mostram que nesta época do ano não é registrado o afloramento médio da ACAS na porção norte da PCSE, e as águas na porção sul são mais frias. Já a distribuição de salinidade é semelhante, com valores levemente superiores para a estação de inverno.

Dentre as principais características da estrutura termohalina apresentadas, se destacam e os mínimos de temperatura superficial: em situação de verão, os menores valores de temperatura média $\left(<21^{\circ} \mathrm{C}\right)$ ocorrem próximo a Cabo Frio, em razão da ressurgência costeira (afloramento na superfície da ACAS); já em período de inverno este mínimo ocorre nas imediações do Cabo de Santa Marta $\left(<18^{\circ} \mathrm{C}\right)$, evidenciando a ação de águas mais frias provenientes do sul do Brasil.

Com relação à salinidade superficial, valores médios acima de 36 são encontrados na borda exterior da PCSE, tanto no verão quanto no inverno, indicando a dominância da AT nessa região, nas duas estações. No verão, os menores valores ocorrem na porção interna da PCSE, notadamente em sua parte central $(<33)$; no inverno, a PCI apresenta valores médios de salinidade em torno de 34. Durante o inverno, as águas mais frias que provêm de sul são também relativamente menos salinas (34). 

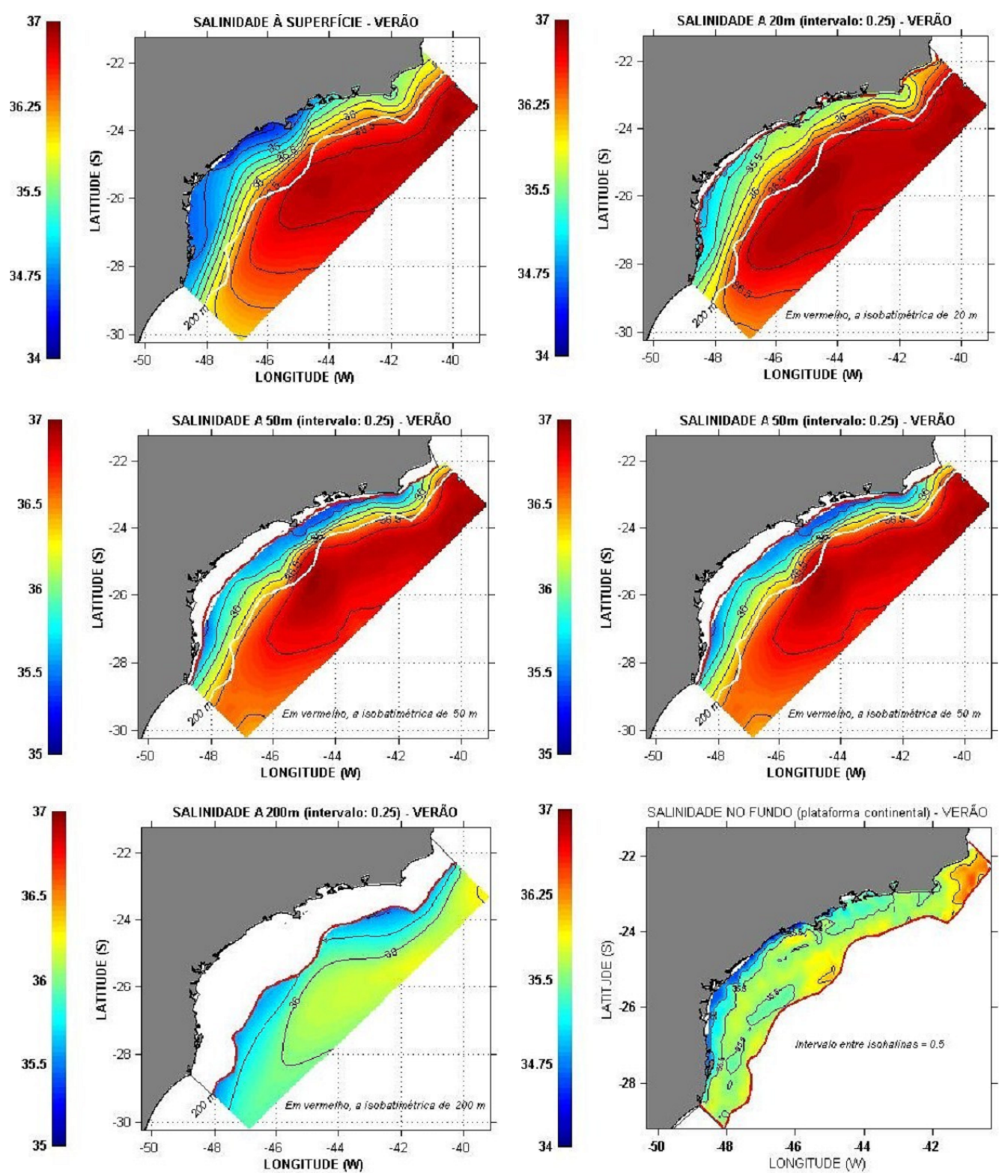

Figura 1.12: Seções horizontais de salinidade média, em superfície (superior esquerdo), $20 \mathrm{~m}$ (superior direito), $50 \mathrm{~m}$ (centro esquerdo), $100 \mathrm{~m}$ (centro direita), $200 \mathrm{~m}$ (inferior esquerdo) e no fundo (inferior direito) da Plataforma Continental Sudeste. Fonte: adaptado de Rezende (2003) 

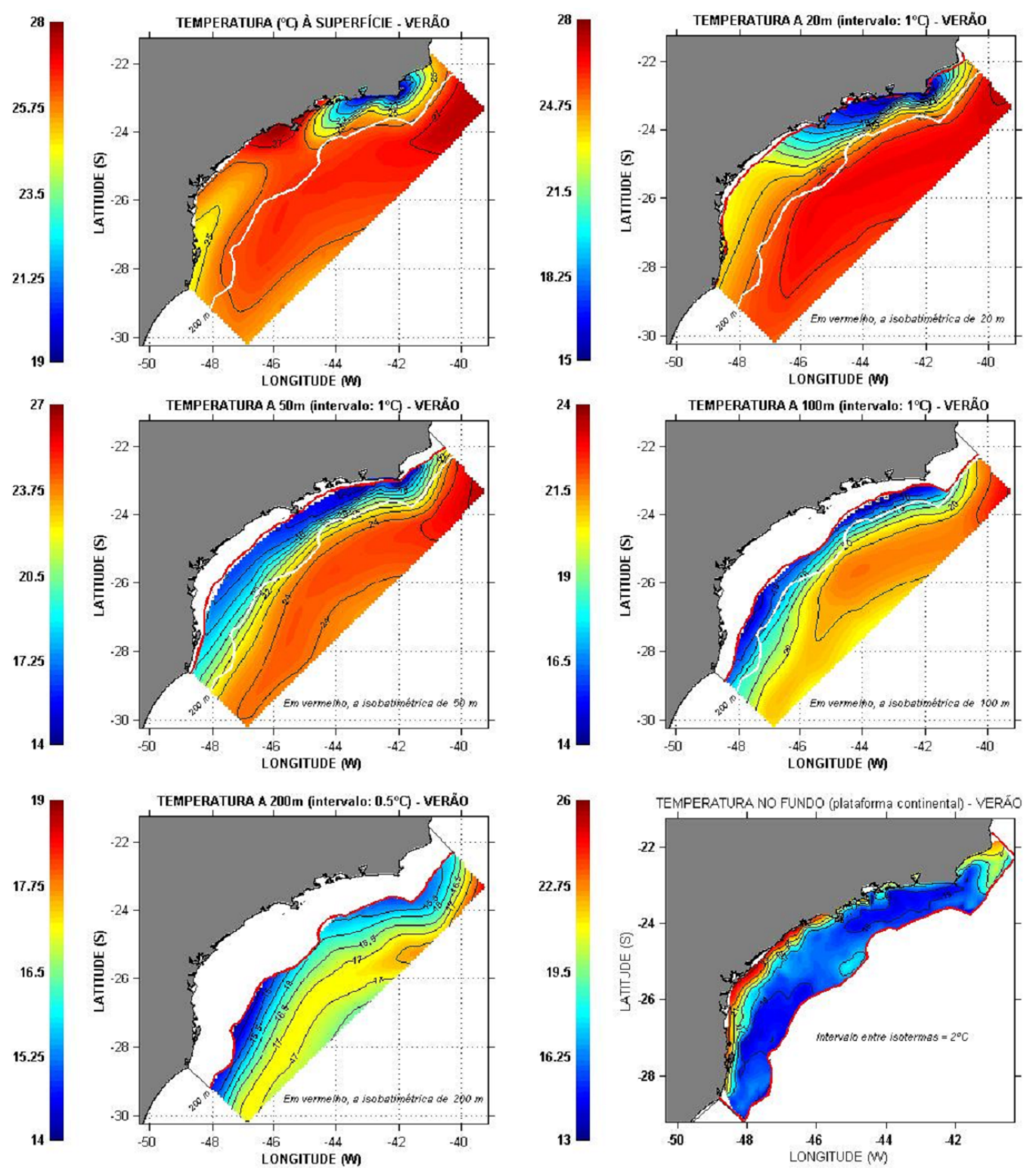

Figura 1.13: Seções horizontais de temperatura média, em superfície (superior esquerdo), $20 \mathrm{~m}$ (superior direito), $50 \mathrm{~m}$ (centro esquerdo), $100 \mathrm{~m}$ (centro direita), $200 \mathrm{~m}$ (inferior esquerdo) e no fundo (inferior direito) da Plataforma Continental Sudeste. Fonte: adaptado de Rezende (2003) 


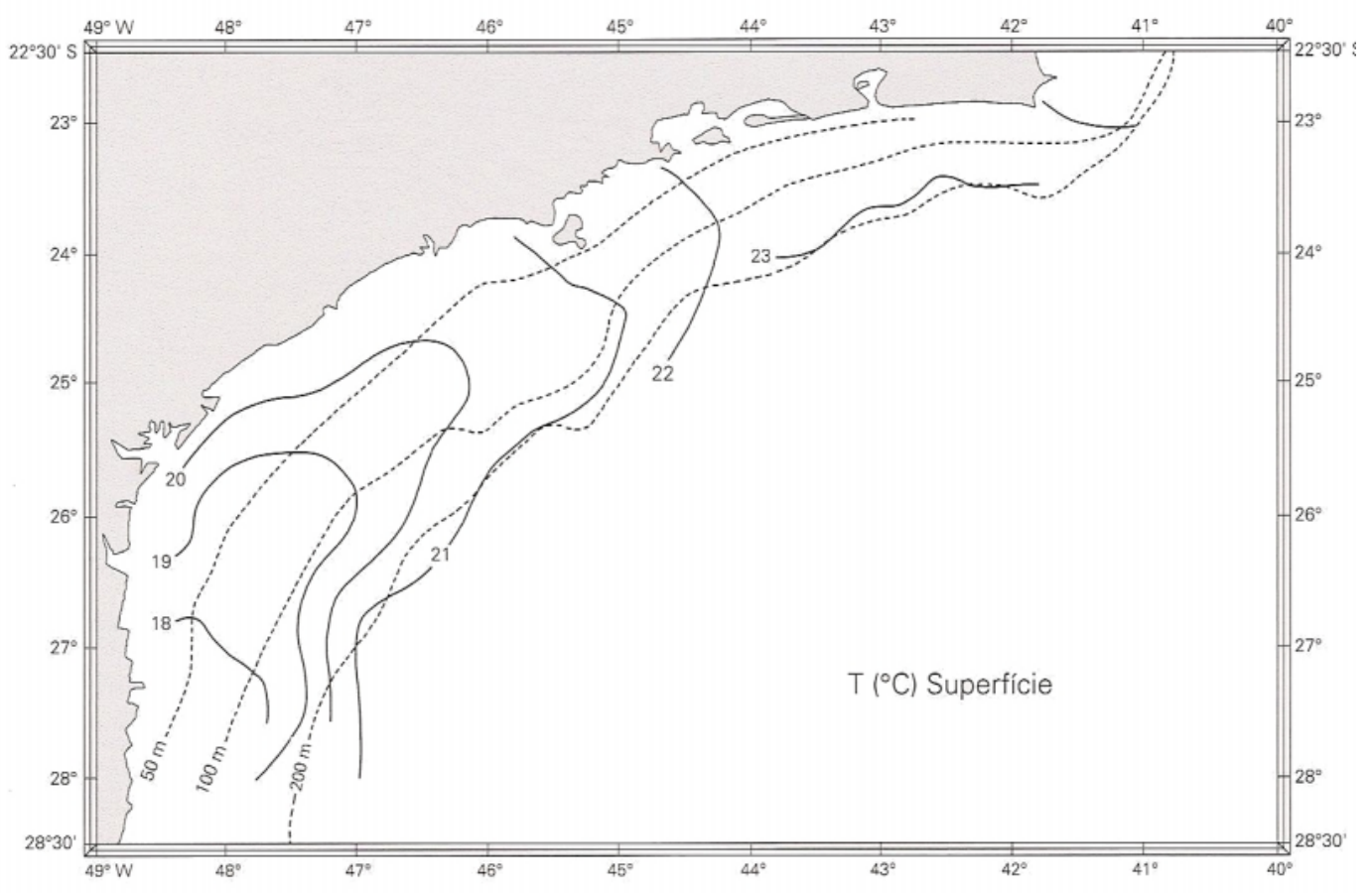

Figura 1.14: Distribuição horizontal superficial de temperatura média para a Plataforma Continental Sudeste em período de inverno. Fonte: Castro \& Miranda (1998)

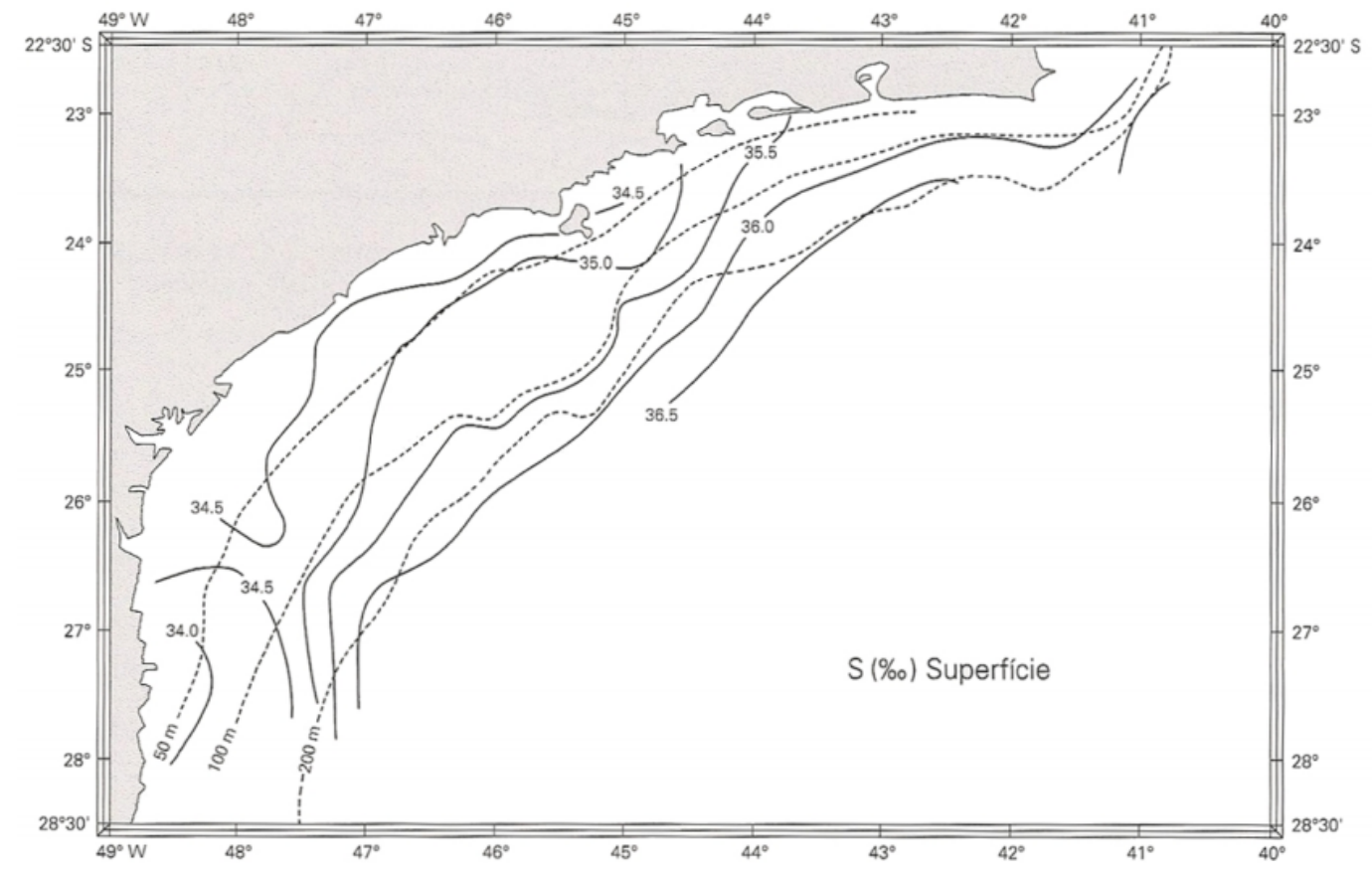

Figura 1.15: Distribuição horizontal superficial de salinidade média para a Plataforma Continental Sudeste em período de inverno. Fonte: Castro \& Miranda (1998) 


\subsubsection{As correntes na Plataforma Continental Sudeste}

Na PCSE as correntes ocorrem devido a combinação de diversas forçantes: marés, ventos, variações do campo de massa e a Corrente do Brasil (CB), cada qual atuando em regiões diferentes e em distintas escalas espaciais e temporais. Os movimentos subinerciais são aqueles forçados pelos ventos médios, ventos de passagem de FF, variações laterais do campo de massa e o escoamento da CB. Além disso, OPC podem trazer às partes central e norte da PCSE influências do vento remoto como forçante para estes fluxos (Castro et al. 2014).

Focando esta descrição para os movimentos subinerciais, as Seções seguintes descrevem os movimentos nos três compartimentos dinâmicos da PCSE: PCI, PCM e PCE.

\section{Plataforma Continental Interna}

Na PCI da PCSE as correntes subinerciais são forçadas principalmente por gradientes de pressão devido à descargas estuarinas e pela tensão de cisalhamento do vento. Segundo Castro (1996), neste compartimento dinâmico as porções mais largas da PCSE não sofrem influência direta da CB.

Como descrito na Seção 1.1.1, na ausência de sistemas meteorológicos frontais, os ventos de leste-nordeste, que fazem parte o ASAS, são os dominantes sobre a PCSE. Esta direção predominante dos ventos associada à orientação da costa ocasiona, em sequência, divergência unilateral do transporte de deriva do vento na costa, rebaixamento da superfície livre do mar, gradientes de pressão essencialmente barotorópicos perpendiculares à costa e correntes geostróficas deixando a costa à direita, na forma de jato costeiro (Csanady 1977). Para os gradientes de pressão devido à descargas estuarinas, as Figuras 1.12 e 1.15 mostram que na PCI são observadas baixas salinidades, principalmente na porção entre Cananéia e São Sebastião durante o verão. Segundo Castro et al. (2014), modelos teóricos (McClimans 1986) mostram que a força do gradiente de pressão quase perpendicular à costa, devida ao fluxo de flutuabilidade associado à estrutura quase horizontal de salinidade, força correntes geostróficas deixando a costa à esquerda. Ou seja, principalmente no verão e ao longo da costa de SP, quando e onde os gradientes de salinidade na PCI são mais intensos, se estabelece uma competição entre a tensão de cisalhamento do vento médio sazonal e a salinidade média sazonal, ambos impulsionando correntes quase paralelas à costa em sentidos opostos (Castro et al. 2014). Assim, dependendo da porção da PCSE e da estação do ano, a direção sazonal média das correntes na PCI pode ser diferente.

Estudando as correntes no litoral de SP, Moreira (1998) encontrou correntes mais frequentes para norte-leste (costa à esquerda) na porção ao sul de São Sebas- 
tião. No mesmo período, contudo na porção ao norte de São Sebastião, as correntes mais frequentes apontaram no sentido oposto, sul-sudoeste, deixando a costa à direita. Exceto no verão, estas correntes apresentaram baixo cisalhamento vertical. Na porção ao norte de São Sebastião, durante o verão foram observadas correntes em superfície apontando para norte-leste (costa à esquerda) e no fundo para sulsudoeste (costa à direita). Para esta região ao norte de São Sebastião na costa de $\mathrm{SP}$, Castro (1996) também encontrou correntes deixando a costa à direita, principalmente no inverno e alto cisalhamento vertical em período de verão. Em dois dos três verões analisados as correntes predominantes apontaram para sul-sudoeste, mas em um deles a direção predominante foi oposta. Para a região ao sul de São Sebastião na costa de SP, Mazzini (2009) também encontrou fluxos predominantes deixando a costa à esquerda. Ao largo de Cabro Frio, Santos (2009) encontrou predominância de correntes sentido leste-sudoeste (costa à esquerda), porém com alta variabilidade subinercial.

Numericamente (Caldas 1978, Rezende 2003, Coelho 2007, Ruffato 2011) confirmaram essas observações para o litoral de SP, e apresentaram alguns outros resultados para as demais regiões da PCI. Analisando somente as correntes médias de verão forçadas exclusivamente pelos gradientes de pressão associados aos gradientes de densidade, Coelho (2007) encontrou correntes deixando a costa à esquerda desde a região de Paranaguá até Cabo Frio. Somando-se a forçante tensão de cisalhamento do vento devido à $\mathrm{ASAS}$, correntes deixando a costa à esquerda foram observadas somente desde Cananéia até o Rio de Janeiro. Rezende (2003) e Ruffato (2011) também encontraram inversão do fluxo em algumas partes da PCI quando o vento típico do ASAS é imposto sobre os fluxos oriundos dos gradientes de pressão associados aos gradientes de densidade.

Além destas correntes médias sazonais, diversos autores encontraram frequentes inversões das correntes em escala de tempo subinercial, que estão associadas à passagens de FF. Conforme apresentado na Seção 1.1.1, os ventos provenientes destes sistemas possuem direção oposta aos do ASAS forçando jatos costeiros na PCI deixando a costa à esquerda. Assim, durante estes eventos, a tensão de cisalhamento do vento soma-se ao gradiente de pressão devido às descargas estuarinas. Numericamente, Coelho (2007) verificou que com a passagem de FF as correntes giram anticiclonicamente deixando a costa à esquerda. Stech \& Lorenzzetti (1992) também avaliaram a contribuição do vento sinótico local sobre a PCSE através de experimento de modelagem matemática numérica. Estes autores encontraram resposta da corrente acompanhando o deslocamento da forçante. Dottori \& Castro (2009) analisando dados coletados e modelos semi-analíticos encontraram também resposta subinercial aproximadamente em fase com o vento. Para o norte de SC e Cabo Frio, Truccolo et al. (2006) e Santos (2009) também encontraram resposta ao 
vento sinótico local.

Além da resposta ao vento local, a variabilidade subinercial das correntes na PCI pode ter alta contribuição de OPC, conforme estudos de Castro (1985), Camargo \& Harari (1994), Castro \& Lee (1995), Uaissone (2004), Rahy (2006), Menezes (2007), Dottori \& Castro (2009), Campos et al. (2010). Campos et al. (2010) atribuíram os eventos extremos observados em Santos, de uma análise de 40 anos, à ação de ventos remotos localizados ao sul. Uaissone (2004), Menezes (2007), Rahy (2006) encontraram baixa correlação entre a elevação do nível do mar e correntes com o vento local, reforçando a hipótese apresentada por Castro \& Lee (1995) da importância da forçante vento remoto. Na porção sul da PCSE, tanto Melo et al. (2003) quanto Filippo et al. (2012), também observaram elevações anômalas da superfície do mar, sendo estas atribuídas a fenômenos ocorridos nas costas da Argentina e Uruguai.

\section{Plataforma Continental Média}

Segundo Castro et al. (2014), na maior parte da PCM as correntes subinerciais são forçadas principalmente pela tensão de cisalhamento do vento, por gradientes de pressão devidos à estratificação de densidade e ocasionalmente pela CB. Os trabalhos nesta porção da PCM indicam dominância da forçante tensão de cisalhamento do vento, com a CB sendo observada nas áreas mais estreitas da PCSE. Já as correntes em resposta às forças dos gradientes de pressão de densidade estão restritas à porção sul da PCSE, durante o inverno, devido à intrusão de água mais fria proveniente do sul do Brasil, conforme apresentado na Seção 1.1.2 (Figura 1.14).

Ao largo de Ubatuba, Castro (1996) observou correntes médias para sul-oeste (costa à direita) em todos os níveis. Resultados similares ao largo de Santos foram obtidos nas observações de Moreira (1998), Souza (2000) e Mazzini (2009). Na região de Cabo Frio, Santos (2009) encontrou, durante o inverno, movimentos médios em superfície para oeste (costa à esquerda) e para o verão com sentido oposto. Na camada de fundo este autor encontrou correntes para oeste (costa à esquerda) em ambas épocas do ano.

Correntes médias obtidas por experimentos numéricos na PCM também mostraram a ação dos ventos associados ao ASAS, com correntes fluindo para sul (costa à direita) (Castro 1985, Rezende 2003, Coelho 2007, Ruffato 2011). Coelho (2007) conseguiu distinguir as correntes opostas da PCM com relação às da PCI na porção entre Santos e Rio de Janeiro.

Tanto os estudos observacionais quanto os numéricos indicam que os ventos oriundos do quadrante sul, associados à $\mathrm{FF}$, forçam correntes para norte (costa à esquerda). Moreira (1998), Souza (2000) e Mazzini (2009), em dados coletados ao largo de Santos, encontraram inversões da corrente, com intervalos entre 5 e 14 dias, mais frequêntes durante o inverno, atribuindo à maior frequência de FF du- 
rante esta época do ano. Considerações similares foram realizadas por Alves (1992) ao largo de Ubatuba. Coelho (2007) indicou que entre o Cabo de Santa Marta e Ubatuba as correntes oriundas dos ventos associados à FF são mais intensas, supostamente atribuída à maior intensidade e persistência da componente do vento paralela à costa.

Além do vento local, Pimenta et al. (2006) na porção sul da PCSE verificaram que a componente remota também pode ser importante para a variabilidade da corrente paralela à costa. Stech \& Lorenzzetti (1992) fizeram também a mesma consideração, sugerindo a propagação de OPC pela PCSE.

\section{Plataforma Continental Externa}

Os trabalhos apresentados até o momento indicam que a CB é a forçante dominante das correntes subinerciais na PCE da PCSE. Alguns trabalhos também ressaltam a importância da tensão de cisalhamento do vento (Castro et al.|2014).

Ao largo de Santos, Moreira (1998), Souza (2000) e Dottori \& Castro (2009) verificaram correntes médias fluindo para sul-sudoeste (costa à direita) em toda a coluna de água. Poucas inversões das correntes foram verificadas por estes autores, sendo estas atribuídas a presença de meandro ou vórtice da $\mathrm{CB}$ na região. Neste local, Dottori \& Castro (2009) encontraram baixa correlação entre os ventos sinóticos e a corrente subinercial. Para a região de Cabo Frio, Santos (2009) encontrou na camada superficial, tanto no verão quanto no inverno, correntes médias para oeste (costa à direita) e na camada de fundo para leste (costa à esquerda). Este autor atribuiu maior influência da CB no período de verão.

Castro et al. (2014) em análises preliminares de fundeios ao largo de Ubatuba, Cabo Frio e Rio de Janeiro encontraram movimentos médios para sudoeste (costa à direita) somente ao largo de Ubatuba. Ao largo do Rio de Janeiro estes autores observaram alta variabilidade das correntes subinerciais, com valores médios com baixa significância estatística. Esta alta variabilidade é atribuída à ação de meandros ou vórtices da CB. Em Cabo Frio foram observados movimentos deixando à costa à direita somente na camada superficial. Na camada de fundo das três localidades os fluxos são para nordeste-leste (costa à esquerda), similarmente ao descrito por Santos (2009).

Dottori \& Castro (2009) analisaram, ao largo de Santos, a oscilação da superfície do mar na costa e na PCE da PCSE e verificaram que as variações subinerciais são muito menores ao largo, concluindo que a resposta da águas ao vento sinótico é confinada na PC.

Desta maneira, a Figura 1.16 apresenta, esquematicamente, as divisões dinâmicas da PCSE, mostrando quais são as massas de água em cada compartimento e as principais forçantes para as correntes subinerciais. 


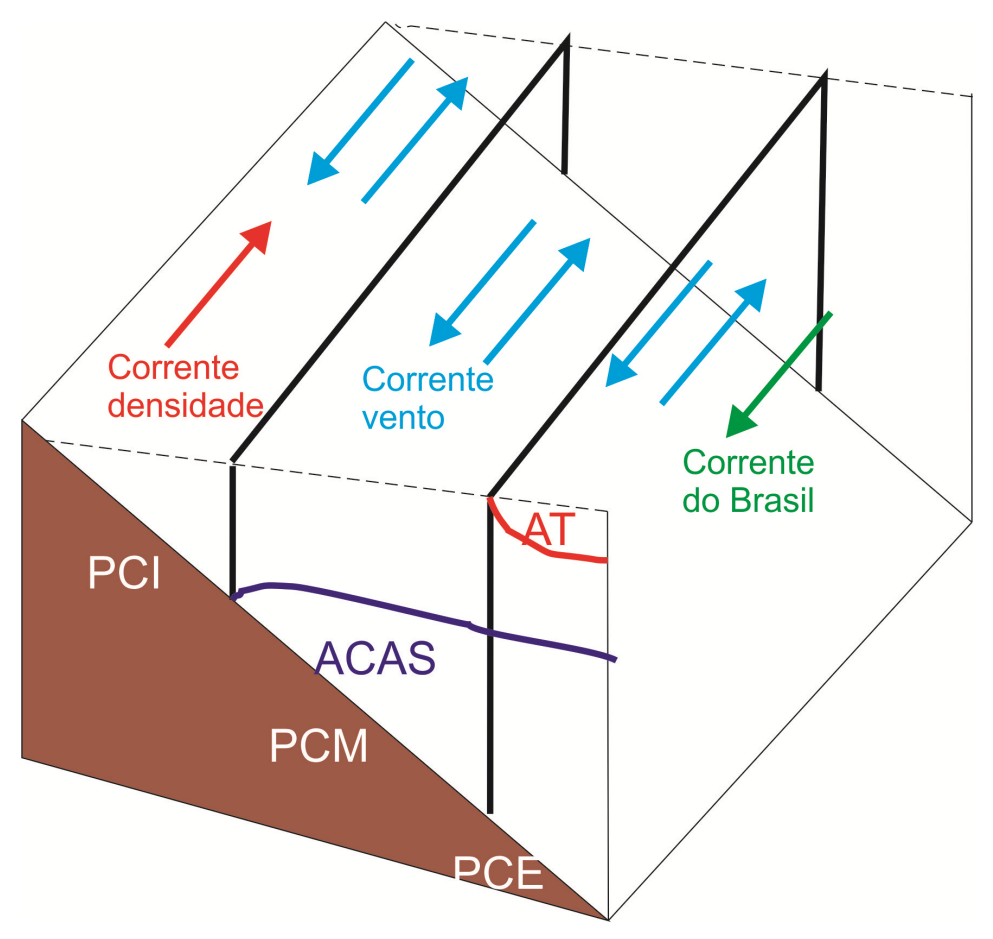

Figura 1.16: Esquema da compartimentação dinâmica da Plataforma Continental Sudeste. PCI: plataforma continental interna; PCM: plataforma continental média; PCE: plataforma continental externa; ACAS: Água Central do Atlântico Sul; AT: Água Tropical. A seta vermelha indica corrente gerada por gradiente de densidade, as setas azuis correntes forçadas pelo vento sinótico e a seta verde a Corrente do Brasil. Fonte: Adaptado de Castro (1996). 


\section{Capítulo 2}

\section{Hipótese Científica e Objetivos}

Os estudos hidrodinâmicos na PCSE indicam que em todos os compartimentos dinâmicos ocorrem oscilações subinerciais (OS), sendo que os forçados pela tensão de cisalhamento do vento são mais energéticos na PCI e na PCM. Entretanto, tanto para a PCI quanto para a PCM, a importância relativa das variabilidades sinóticas da tensão de cisalhamento do vento local e remota sobre a elevação da superfície do mar ainda não foi determinada. Alguns autores, como Castro (1985), Camargo \& Harari (1994), Castro \& Lee (1995), Melo et al. (2003), Uaissone (2004), Rahy (2006), Menezes (2007), Dottori \& Castro (2009), Campos et al. (2010) e Filippo et al. (2012) atribuíram à componente remota certas OS que não são explicadas pelo vento local.

Assim, a hipótese científica desta Tese de Doutorado é que as OS na PCSE são forçadas tanto pela variabilidade sinótica da tensão do cisalhamento do vento local, quanto do vento remoto, e que estas OS podem se propagar em forma de OC.

Portanto, o objetivo principal deste trabalho é quantificar a importância relativa das componentes local e remota do vento sobre as OS na PCSE.

Para cumprir o objetivo principal, alguns objetivos específicos foram propostos:

- Validar um banco de dados de velocidade do vento e pressão atmosférica para a região da PCSE;

- Criar e validar um banco de dados de variação do nível do mar para a região da PCSE;

- Estudar as FF que percorrem toda a extensão da PCSE comparadas a fenômenos que não percorrem toda a extensão da PCSE, definindo uma climatologia para ambas;

- Identificar as características principais das OPC que se propagam na PCSE e forçam as OS. 


\section{Capítulo 3}

\section{Metodologia}

Uma ferramenta comumente utilizada em estudos meteoceanográficos é o emprego de métodos numéricos para a solução das equações governantes que, quando aplicados e validados de forma correta, podem gerar um banco de dados robusto, visando suprir a carência de dados coletados in situ. Assim, para esta Tese de Doutorado, a modelagem numérica computacional foi escolhida como sendo a ferramenta base para obtenção de dados para o estudo das OS na PCSE. Ambas as componentes atmosférica e oceânica, utilizadas neste estudo são oriundas de simulações computacionais. É importante destacar que para a devida validação destas bases numéricas, foram selecionados dados coletados diretamente na região da PCSE, e estes comparados e validados com os dados resultantes dos modelos utilizados. A Figura 3.1 resume a metodologia utilizada

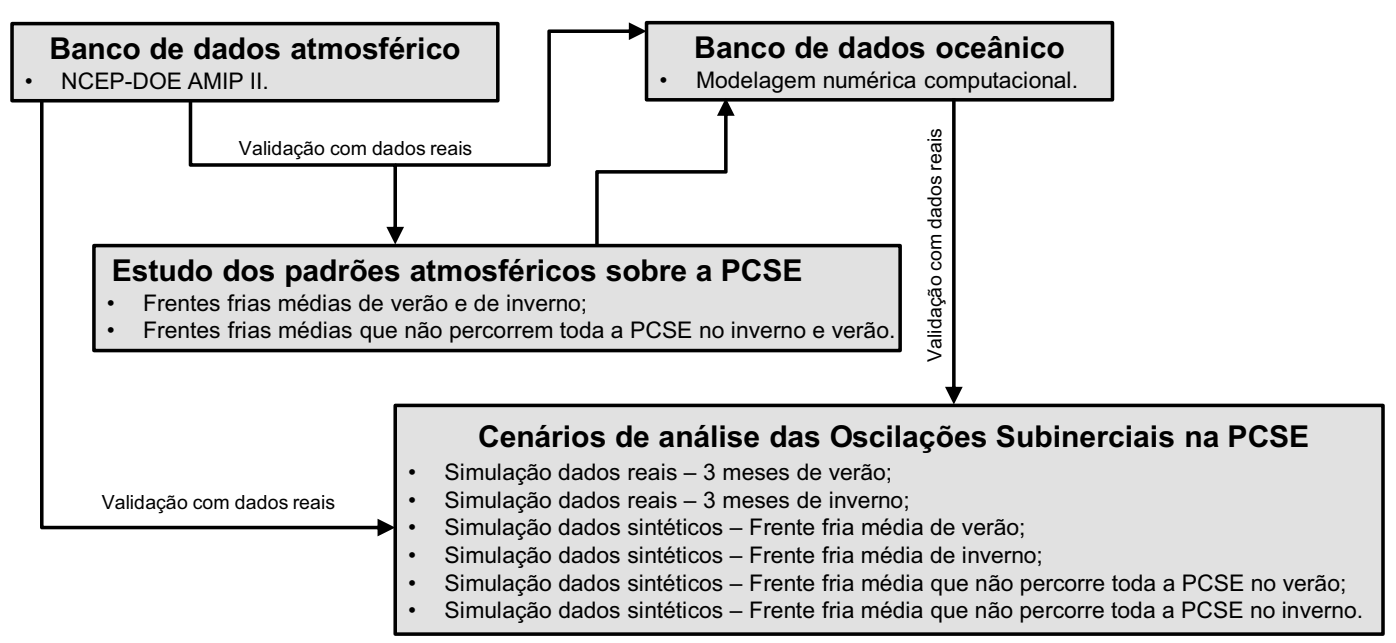

Figura 3.1: Metodologia utilizada nesta tese de doutorado para estudo das oscilações subinerciais na Plataforma Continental Sudeste.

A Figura 3.1 também mostra que os cenários de análise das OS na PCSE são oriundos de dois bancos de dados distintos: atmosférico (BDA) e oceânico (BDO). 
O BDA subsidia o estudo dos padrões de ventos sobre a PCSE, onde as FF têm destaque. Tanto o BDA quanto o estudo dos padrões de ventos alimentam o BDO. Ao final, 6 cenários de análise de OS na PCSE são propostos, provenientes de ambos bancos de dados.

Importante ressaltar que os meses de verão aqui considerados correspondem ao período entre janeiro e março e os meses de inverno ao período entre julho e setembro.

\subsection{Banco de dados atmosférico}

Para a componente atmosférica do estudo (temperatura, ventos e pressão atmosférica), existem diversos modelos de referência no mundo que disponibilizam dados de previsões e de reanálises. Foram avaliados diversos bancos de dados e o que melhor se adequou à região de estudo foram os dados da reanálise do National Centers for Environmental Prediction/Department of Energy Atmospheric Model Intercomparison Project II (NCEP-DOE AMIP II) dos Estados Unidos da América. Maiores detalhes sobre este projeto podem ser obtidos em Kanamitsua et al. (2002).

Deste banco de dados foram utilizados dados de vento a $10 \mathrm{~m}$ de altura, pressão atmosférica e temperatura atmosférica superficial. A distribuição utilizada é de escala global, com resolução espacial de $2,5^{\circ}$ e resolução temporal de $6 \mathrm{~h}$. Para o estudo dos padrões de ventos sobre a PCSE e nas simulações numéricas hidrodinâmicas foram utilizados dados abrangendo o período entre 01/01/1982 e 31/12/2011, totalizando 30 anos. Para a validação deste banco de dados também foram utilizados dados do ano de 2012.

Os dados desta reanálise foram comparados com dados coletados em estações meteorológicas nas regiões costeira e oceânica da PCSE. As características, quanto à localização, origem, abrangência espacial e propriedades de coleta dos dados atmosféricos utilizados estão apresentados na Tabela 3.1. A localização geográfica destas estações meteorológicas está disponível na Figura 3.2. Estes dados de estações foram escolhidos de acordo com a representatividade temporal (mínimo de 1 mês de coleta de dados de maneira ininterrupta) e local de coleta (abrangência sul, central e norte da PCSE, em área oceânica e costeira). Como o BDA tem uma abrangência temporal relativamente grande, e foi utilizado para o estabelecimento de padrões médios atmosféricos sobre a PCSE, foram utilizados dados coletados para a sua validação em diversos períodos, e assim não obrigatoriamente todas as série coletadas possuem a mesma abrangência temporal.

Os dados atmosféricos de estações selecionados para validar o BDA sofreram o seguinte tratamento:

- Foram utilizados para validação somente dados de velocidade (intensidade e direção) dos ventos e pressão atmosférica; 
- Os dados de velocidade do vento foram decompostos em componentes paralela e perpendicular à costa, de acordo com o local de análise;

- Não foram utilizadas séries de dados com intervalos de amostragem superior a $6 \mathrm{~h}$;

- As séries de tempo sofreram tratamento estatístico de remoção de dados espúrios onde, supondo uma distribuição normal gaussiânica, foram removidos das séries valores inferiores a média menos 3 vezes o desvio padrão, ou aqueles valores superiores à média mais 3 vezes o desvio padrão, preservando desta maneira 99\% dos dados (Emery \& Thomson 2001);

- Todas as séries de tempo das estações foram reamostradas em intervalos regulares de $1 \mathrm{~h}$, por método de interpolação linear.

Após o tratamento realizado sobre os dados de estação conforme descrito, foram criadas séries de dados do banco do NCEP-DOE AMIP II nos locais de coleta de dados (estações), por meio de interpolação espacial linear. Estas séries pontuais foram, então, interpoladas em intervalos regulares de $1 \mathrm{~h}$. As séries de tempo coletadas em estações e as do banco de dados do NCEP-DOE AMIP II foram comparadas por meio de análise gráfica e estatística. As comparações estatísticas foram realizadas por meio de análise de médias, mínimo, máximos, amplitudes e variância das séries. Além disso, as séries foram submetidas a análises estatísticas comparativas de Correlação (Corr), Skill $(S)$ e Coeficiente de Ajuste (NRMS) .

A Corr é a medida padronizada da relação linear entre duas variáveis. Ela é calculada através da covariância $(C o v)$ e dos desvios padrões $(D P)$ das séries analisadas:

$$
\operatorname{Corr}\left(X_{o b s}, X_{\text {mod }}\right)=\frac{\operatorname{Cov}\left(X_{o b s}, X_{\text {mod }}\right)}{D P\left(X_{o b s}\right) * D P\left(X_{\text {mod }}\right)}
$$

onde, $X_{o b s}$ é o valor de comparação (estação), $X_{m o d}$ é o valor a ser comparado (NCEP-DOE AMIP II). A covariância (Cov) é dada por:

$$
\operatorname{Cov}\left(X_{o b s}, X_{m o d}\right)=\frac{\sum_{i=1}^{n}\left(X_{o b s_{i}}-\overline{X_{o b s}}\right)\left(X_{m o d_{i}}-\overline{X_{m o d}}\right)}{n}
$$

com $n$ sendo o número total de observações, $\overline{X_{o b s}}$ o valor médio de comparação (estação) e o $\overline{X_{m o d}}$ é o valor médio a ser comparado (NCEP-DOE AMIP II). DP, desvio padrão, é dado por:

$$
D P(X)=\sqrt{\sum_{i=1}^{n} \frac{X_{i}-\overline{X^{2}}}{n}} .
$$




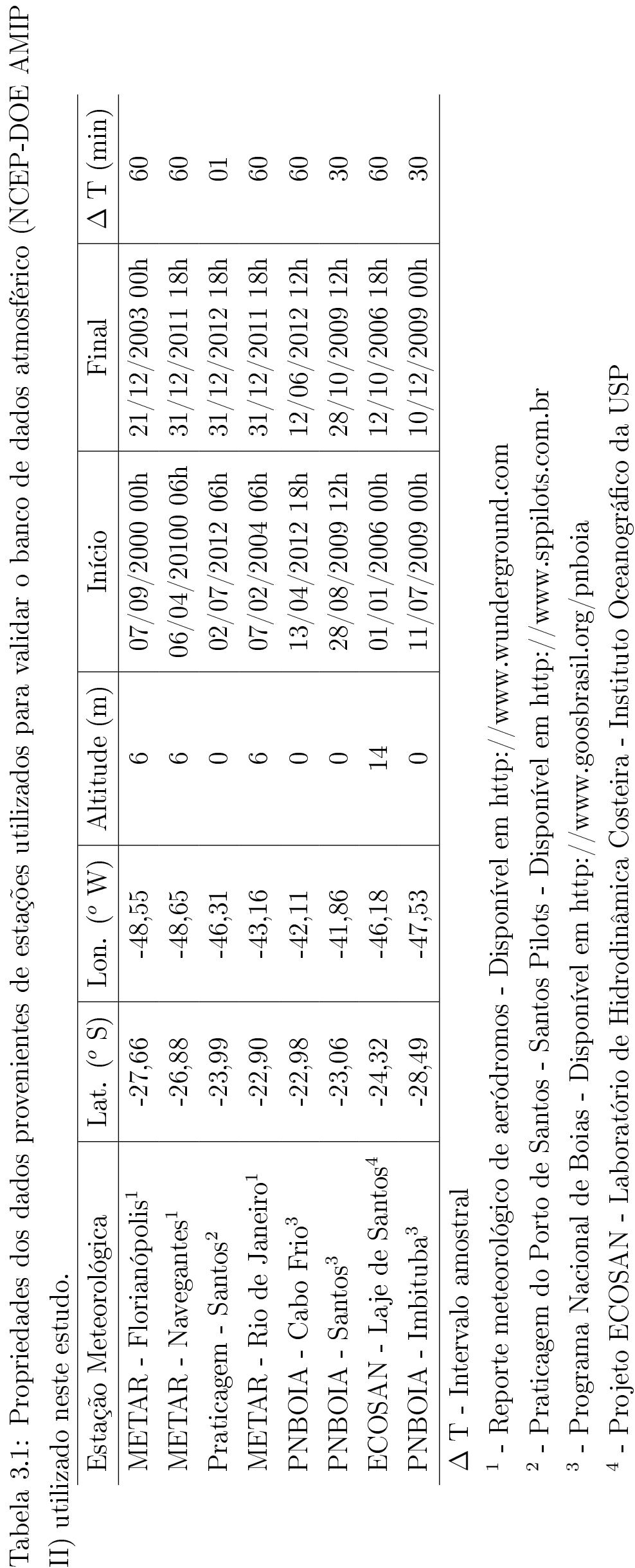




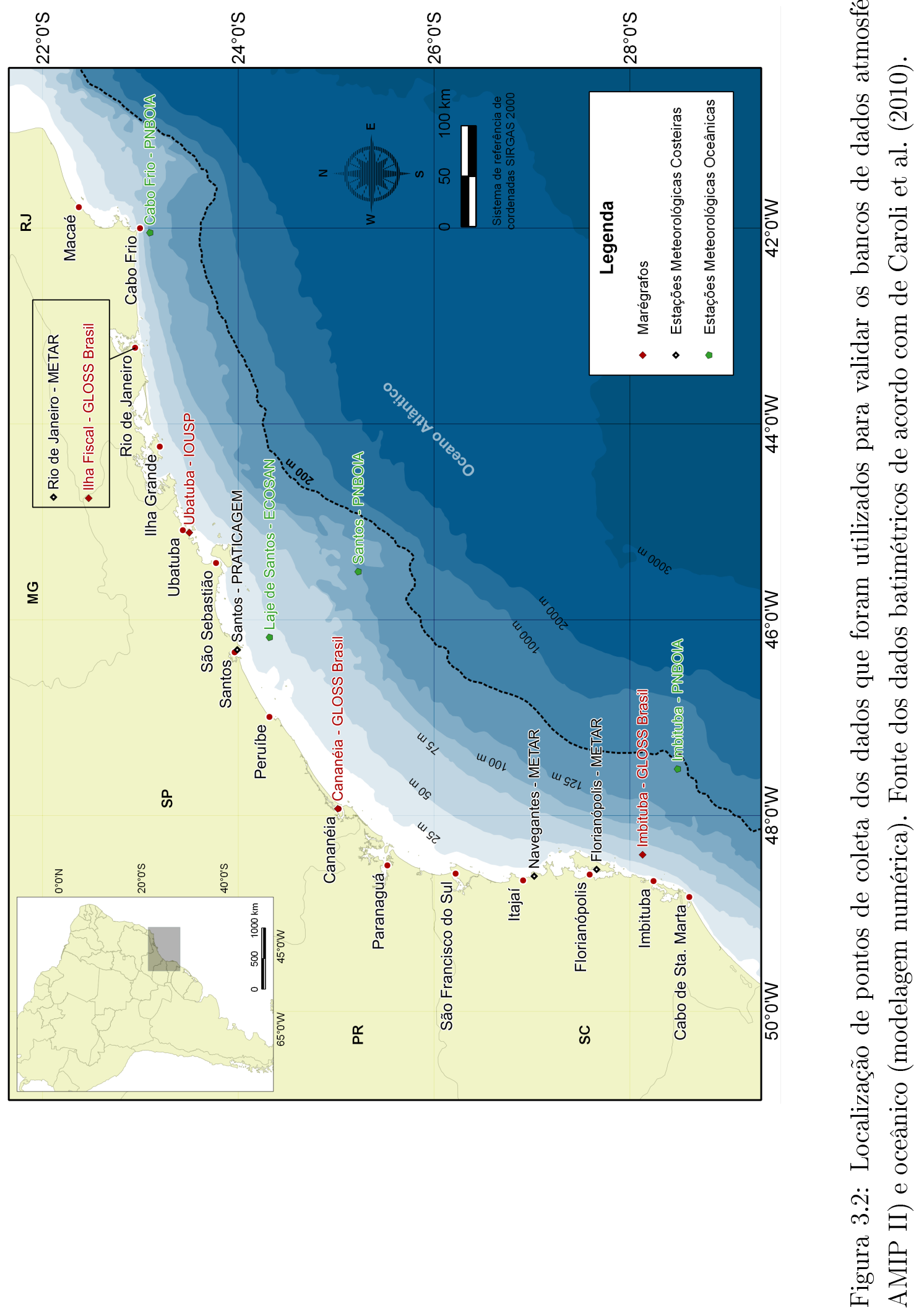


O método estatístico denominado Skill (S), desenvolvido por Wilmott (1981) e descrito por Warner et al. (2005), compara duas grandezas escalares e é dado por:

$$
S=1-\frac{\sum\left|X_{\text {mod }}-X_{o b s}\right|^{2}}{\sum\left(\left|X_{\text {mod }}-\left(\overline{X_{o b s}}\right)\right|+\left|X_{o b s}-\left(\overline{X_{o b s}}\right)\right|\right)^{2}}
$$

Quando $S=1$ há concordância total entre os resultados modelados e as observações. No outro extremo, quando $S=0$ a concordância é nula.

O NRMS pode ser utilizado para qualquer série escalar e é baseado em Hess \& Bosley (1992), cuja formulação é frequentemente utilizada na literatura científica para a comparação de duas séries com periodicidades relativamente definidas. $\mathrm{O}$ coeficiente é definido pela normalização do erro quadrático médio (Equações 3.5 e 3.6) e o resultado aparece em percentagem (quanto maior a percentagem, maior o erro).

$$
\begin{gathered}
N R M S=\frac{R M S}{\overline{X_{o b s}}} \\
R M S=\sqrt{\frac{\sum_{i=1}^{n}\left(X_{o b s}-X_{m o d}\right)^{2}}{n}}
\end{gathered}
$$

Para a análise dos processos subinerciais utilizamos um filtro passa-baixa, com frequência de corte de $40 \mathrm{~h}$, do tipo Lanczos quadrático descrito em detalhes em Walters \& Heston (1982). Na região da PCSE o período inercial é próximo a 29 h. Assim as séries de tempo submetidas a esta filtragem retém a maior parte dos processos subinerciais.

Séries de dados das componentes da velocidade do vento e pressão atmosférica provenientes do BDA sofreram análise espectral. Esta análise foi conduzida de acordo com a teoria descrita em Emery \& Thomson (2001). Para estimar o número de graus de liberdade utilizado na análise foi utilizada relação proposta por Elgar (1987), diretamente proporcional ao intervalo amostral, chegando ao valor de 10,5.

\subsection{Estudo dos padrões atmosféricos sobre a Plata- forma Continental Sudeste}

Neste estudo foi proposto verificar qual o padrão de ventos sobre a PCSE. Estes ventos são provenientes do ASAS e de FF. De acordo com o apresentado no Capítulo 1. os ventos provenientes do ASAS são os ventos médios que afetam a PCSE e as FF são os eventos sinóticos que alteram a hidrodinâmica da PCSE. Assim, neste estudo foi utilizado o BDA apresentado na Seção 3.1. contemplando 30 anos (NCEP-DOE AMIP II). 
Para a obtenção dos campos médios atmosféricos de ventos, pressão atmosférica e temperatura atmosférica superficial, foi estimada a média temporal simples para os meses de verão e de inverno. Para estudar as FF que passam sobre a PCSE foi proposto um método objetivo de identificação de FF. O método aqui desenvolvido está de acordo com a combinação de métodos propostos por Cavalcanti \& Kousky (2003), Rodrigues et al. (2004), e Andrade (2007). Esta metodologia consiste em identificar, em alguns pontos de grade do BDA, o intervalo temporal da passagem de FF. Para a identificação do momento de tais passagens foram utilizadas as seguintes premissas:

- Componente norte-sul do vento positiva (indicando vento proveniente de sul);

- Variação da pressão atmosférica negativa no dia anterior a virada do vento de sul (indicando queda de pressão);

- Variação negativa da temperatura superficial entre o dia anterior e dois dias após a virada de vento do sul (identificando queda de temperatura).

Como foi identificado que na região da PCSE podem ocorrer FF que percorrem toda sua extensão e outras que não percorrem toda esta distância, foi proposta a identificação das FF em três pontos distintos, cujas posições geográficas estão apresentadas na Figura 3.3, conjuntamente à grade de dados da reanálise NCEPDOE AMIP II. Estes dados representam os pontos mais próximos aos extremos norte e sul da PCSE e um ponto central, cujas coordenadas geográficas são:

- SUL $\left(29,5^{\circ} \mathrm{S}, 48,75^{\circ} \mathrm{W}\right)$ - Região ao sul da PCSE (próximo à fronteira SC/RS);

- CENTRO $\left(25,75^{\circ} \mathrm{S}, 45,00^{\circ} \mathrm{W}\right)$ - Região central da PCSE;

- NORTE $\left(22,00^{\circ} \mathrm{S}, 39,5^{\circ} \mathrm{W}\right)$ - Região norte da PCSE (próximo à fronteira $\mathrm{RJ} / \mathrm{ES})$.

Assim, os intervalos temporais em que as premissas listadas anteriormente são válidas indicam que a atmosfera da PCSE está sobre a influência de FF. Situações em que a identificação de FF ocorre nos três pontos indicam eventos que percorreram toda a extensão da PCSE. Já eventos que foram identificados no ponto SUL, mas não foram observadas no ponto CENTRAL e NORTE, indicam FF que não percorreram toda a extensão da PCSE. Eventos que foram registrados somente nos pontos SUL e CENTRAL não foram considerados como eventos que não percorreram toda a extensão da PCSE pois, devido à escala espacial deste fenômeno, as modificações atmosféricas são semelhantes àquelas que percorrem toda a extensão da PCSE. Assim, estas FF também foram classificadas como sendo FF que percorreram toda a extensão da PCSE. Portanto, FF identificadas nos pontos SUL e CENTRO ou SUL, 
CENTRO e NORTE foram classificadas como FF que percorreram toda a PCSE. Já as FF que foram identificadas somente no ponto SUL foram classificadas como FF que não percorrem toda a extensão da PCSE. A partir dos campos de ventos, pressão e temperatura das $\mathrm{FF}$ foram obtidos fenômenos médios de verão e inverno através da média temporal nos períodos selecionados.

Após obtidas as FF climatológicas e o padrão atmosférico sobre a PCSE, os valores foram interpolados em uma grade regular de $0,5^{\circ}$ × $0,5^{\circ}$ abrangendo a área entre $30^{\circ} \mathrm{S}$ e $22^{\circ} \mathrm{S} ; 50^{\circ} \mathrm{W}$ e $40^{\circ} \mathrm{W}$ (região da PCSE), com objetivo de melhor visualização e análise dos resultados. Para analisar temporalmente as FF, foram propostos três pontos, localizados nas seguintes coordenadas:

- $\operatorname{PSC}\left(27,5^{\circ} \mathrm{S}, 48,0^{\circ} \mathrm{W}\right)$ - Região sul da PCSE (próximo à costa de $\mathrm{SC}$ );

- PSP $\left(24,5^{\circ} \mathrm{S}, 46,5^{\circ} \mathrm{W}\right)$ - Região central da PCSE (próximo à costa de SP);

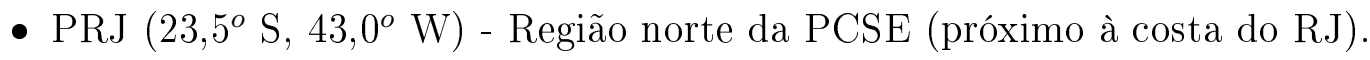

Tanto a grade de interpolação quanto os pontos selecionados estão mostrados na Figura 3.3 .

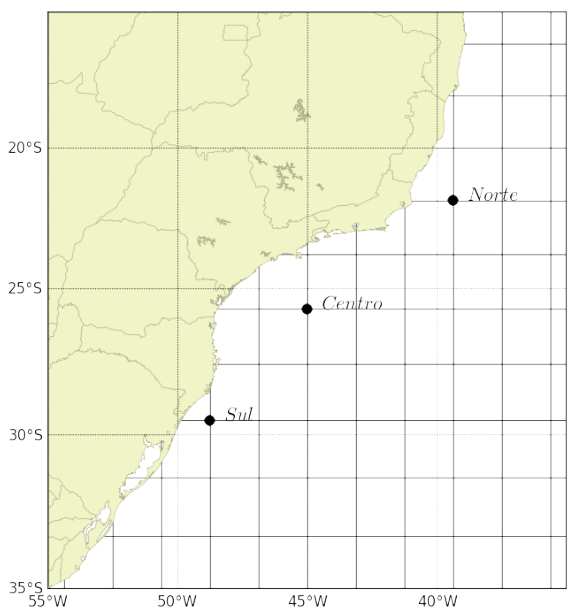

(a)

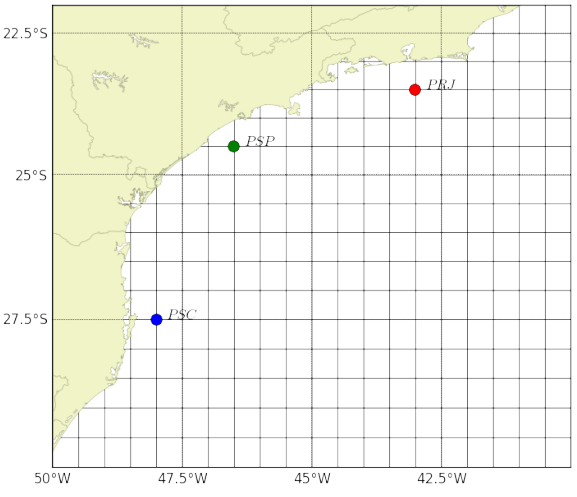

(b)

Figura 3.3: Grade da reanálise NCEP-DOE AMIP II e os três pontos de análise de passagens de frentes frias (painel (a)). O painel (b) mostra a grade de interpolação e os pontos de análise das frentes frias médias obtidas pelo estudo de padrões de ventos sobre a Plataforma Continental Sudeste.

Alguns períodos de passagens de FFs foram selecionados aleatoriamente e comparados com cartas cartas sinóticas da Marinha do Brasil. As variações dos campos 
de ventos, pressão atmosférica e temperatura foram comparados com dados da literatura. A quantidade de FF identificada também foi validada com literatura especializada, como CPTEC/INPE (1996) do Centro de Previsão de Tempo e Estudos Climáticos do Instituto de Pesquisas Espaciais.

Estes campos médios de ventos e pressão atmosférica provenientes do ASAS, FF médias que percorrem toda a extensão da PCSE e FF médias que não percorrem toda a extensão da PCSE, foram utilizados como forçantes das simulações numéricas que compõem o BDO.

\subsection{Experimentos numéricos}

Nos experimentos numéricos que compuseram o BDO foi utilizado o modelo hidrodinâmico DELFT3D - FLOW 4.00.00 (Deltares 2010). Este é um modelo de simulação multidimensional que calcula escoamentos e transportes não estacionários forçados por descargas fluviais, marés e processos meteorológicos. Este modelo emprega uma grade horizontal curvilínea, e suporta como coordenadas verticais a transformação conhecida na literatura por sigma $(\sigma)$ introduzida por Phillips (1957), resultando numa representação suave da topografia de fundo. Este modelo resolve as equações hidrodinâmicas aproximadas para águas rasas discretizadas em diferenças finitas. A configuração das variáveis na grade é do tipo Arakawa-C, com os pontos de pressão (nível) localizados no centro das células e as componentes de velocidade situadas nas faces, de forma perpendicular. Maiores detalhes sobre as equações e a implementação em diferenças finitas podem ser obtidos em Deltares (2010) e de forma resumida no Apêndice A desta Tese de Doutorado.

O modelo de fechamento turbulento utilizado nas simulações numéricas foi o $k-\epsilon$ (Uittenbogaard et al. 1992). Os coeficientes de viscosidade e difusividade horizontal utilizados variaram de acordo com a resolução da grade de $10 \mathrm{~m}^{2} . \mathrm{s}^{-1}$ a $100 \mathrm{~m}^{2} . \mathrm{s}^{-1}$. Para a vertical, estes valores foram de $10^{-4} \mathrm{~m}^{2} \cdot \mathrm{s}^{-1}$ e $7 \times 10^{-4} \mathrm{~m}^{2} \cdot \mathrm{s}^{-1}$, respectivamente. Estes valores foram testados dentro das recomendações de Deltares (2010) e de acordo com os estudos de Martinez \& Allen (2004), Pereira et al. (2005) e validados a partir da comparação com dados coletados na PCSE.

A grade horizontal curvilínea empregada (Figura 3.4) compreende toda a extensão da PCSE, atingindo o talude continental adjacente e parte do sopé continental, até a profundidades de $2000 \mathrm{~m}$ (profundidades superiores à $2000 \mathrm{~m}$ foram consideradas iguais a este valor). São consideradas também as Baías Norte e Sul de Florianópolis, a Baía de Paranaguá, de Cananéia, Canais do Porto de Santos e de São Vicente, Canal de São Sebastião, Baía de Ilha Grande e da Guanabara.

A grade contém $202 \times 329$ pontos nas direções horizontais (totalizando 52375 pontos molhados) com resolução de cerca de $1500 \mathrm{~m}$ na região da PCI, entre $2000 \mathrm{~m}$ 
e 4000 m na PCM e cerca de 5000 m na região da quebra da PCSE. Nas regiões oceânicas adjacentes a resolução mínima empregada foi de $16000 \mathrm{~m}$. Na direção vertical foram utilizados 50 níveis, com resolução variando de acordo com a Figura 3.5. A batimetria empregada foi a descrita por de Caroli et al. (2010), combinando medições diretas, cartas náuticas digitalizadas e dados provenientes de satélites.

No domínio numérico foram introduzidas três bordas abertas: norte, sul e oceano adjacente. Nestas, a componente tangencial da velocidade foi considerada nula, assumindo-se que o fluxo é normal. Para reduzir a reflexão de ondas curtas, nestas bordas foi implementada a solução proposta por Engquist \& Majda (1977) e Engquist \& Majda (1979), que necessita da prescrição do parâmetro $\alpha$ (aqui utilizado como 100, de acordo com Deltares (2010)). Nestas bordas foi simulada a co-oscilação da maré astronômica a partir das componentes de marés obtidas do modelo global TPXO 7.2 (Egbert \& Erofeeva 2002), para os harmônicos $\mathrm{M}_{2}, \mathrm{~S}_{2}, \mathrm{~N}_{2}, \mathrm{~K}_{2}, \mathrm{~K}_{1}, \mathrm{O}_{1}$, $\mathrm{P}_{1}, \mathrm{Q}_{1}, M_{4}, M_{S 4}$ e $M_{N 4}$. Para a condição de borda para o fundo oceânico foi utilizada a formulação de White Colebrook's (Colebrook \& White 1937), com coeficiente de atrito uniforme de $0,03 \mathrm{~m}^{1 / 2} \cdot \mathrm{s}^{-1}$, representando o solo como areia. Na condição de borda de superfície a tensão de cisalhamento foi determinada de acordo com expressão quadrática descrita por Smith \& Banke (1975a) com coeficiente de arrasto do vento constante de 0,0012. Estes valores foram avaliados e adequados de acordo com as análises de comparação com dados observados.

Para a determinação do campo inicial e condição de borda termohalina consideramos que, principalmente na PCI e PCE, a variação espacial do campo de massa (componente baroclínica) do oceano interfere na circulação em escala subinercial, de acordo como o descrito na Seção 1. Na PCI, principalmente durante o verão, ocorre a presença de pluma de água menos salina, principalmente nas porção entre Cananéia e São Sebastião, e na PCE existe a CB. Como os movimentos gerados por estas variações laterais do campo de massa têm frequência subinercial, e as OS aqui estudadas nesta Tese de Doutorado possuem a mesma classe de período, para que neste estudo possamos identificar somente alterações provocadas pelo vento, optamos por negligenciar as variações laterais do campo de massa. Assim, nas simulações aqui desenvolvidas para compor o BDO as correntes subinerciais devido aos gradientes laterais de densidade, principalmente na PCI e na PCE, não são consideradas. Para efetivar esta simplificação, o campo de massa foi considerado horizontalmente homogêneo, com estratificação de massa dependente somente da profundidade. Desta maneira, utilizamos o perfil médio de temperatuea e salinidade (Figura 3.5) da climatologia World Ocean Atlas 2009 - WOA09 (Locarnini et al. (2010); Antonov et al. (2010)), com resolução de 0,25 na região da PCSE. Estes mesmos perfis foram introduzidos nas bordas abertas do domínio modelado. 


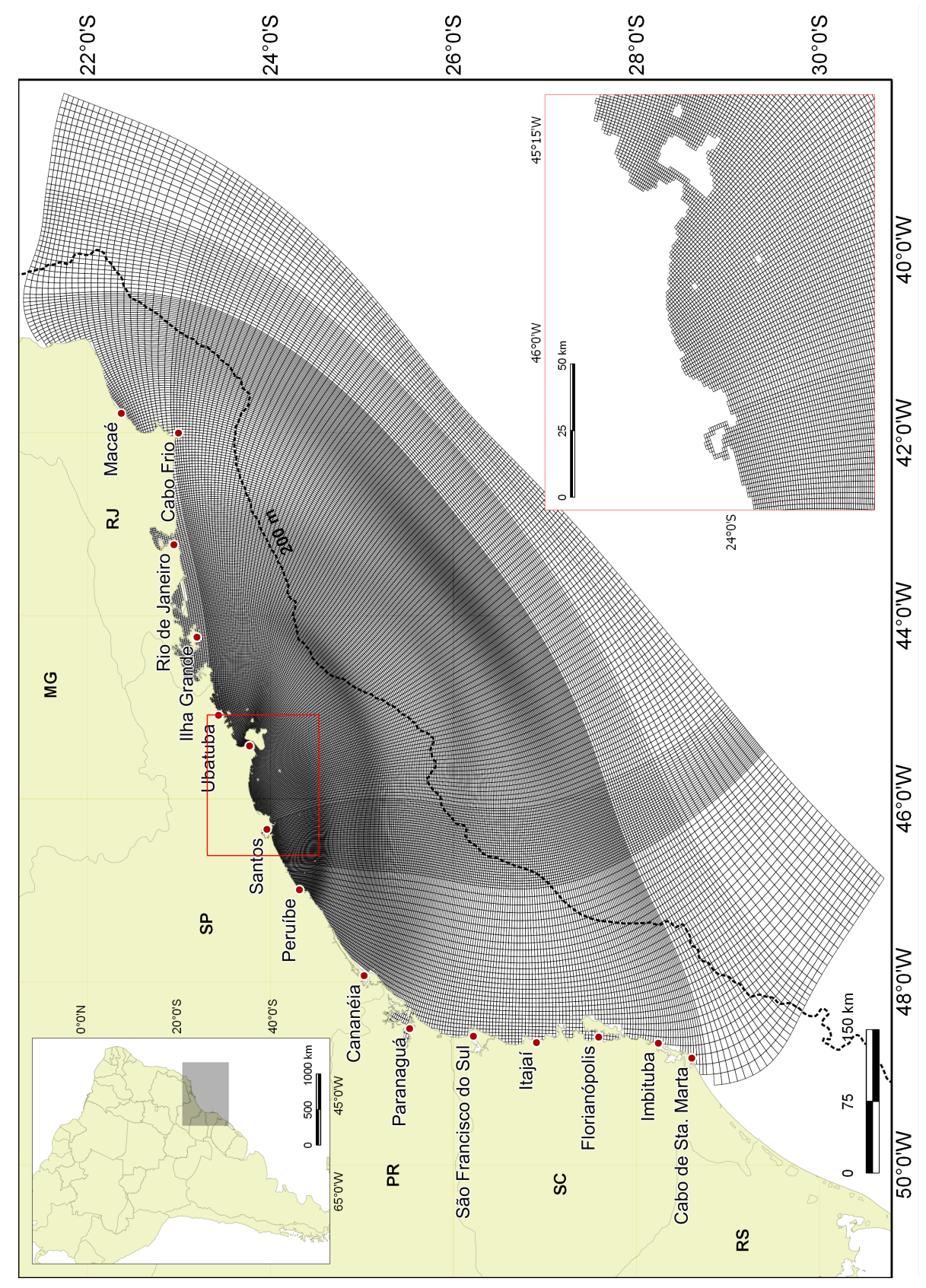



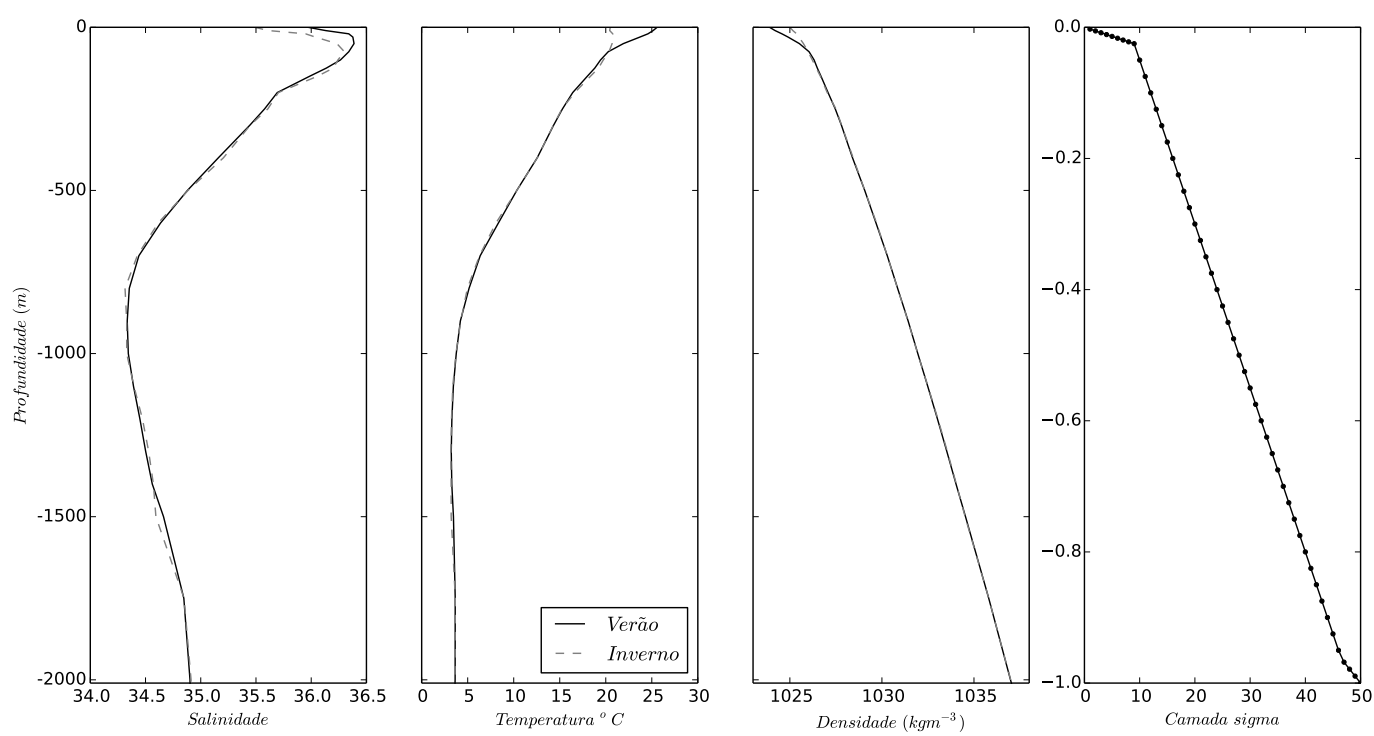

Figura 3.5: Da esquerda para a direita: perfil vertical de salinidade, temperatura e densidade utilizados nos experimentos numéricos (linha preta perfil anual, vermelha verão e azul inverno). No painel da direita a distribuição vertical da coordenadas sigma introduzidas no modelo.

Combinando os campos de massa sazonais de verão e inverno com a componente atmosférica, os experimentos numéricos propostos para compor o BDO estão apresentados na Tabela 3.2 .

Tabela 3.2: Experimentos numéricos propostos para compor o BDO. VR representa vento real, VM vento médio, PFF passagem de frente fria e FFD passagem de frente fria que não percorre toda a extensão da PCSE.

\begin{tabular}{|c|c|c|c|}
\hline Exp. & Marés & Campo TS & Ventos \\
\hline $1 \mathrm{~A}$ & \multirow{6}{*}{ Presente } & Verão & VR Verão \\
\hline $1 \mathrm{~B}$ & & Inverno & VR Inverno \\
\hline $2 \mathrm{~A}$ & & Verão & VM Verão + PFF Verão \\
\hline $2 \mathrm{~B}$ & & Inverno & VM Inverno + PFF Inverno \\
\hline $3 \mathrm{~A}$ & & Verão & VM Verão + FFD Verão \\
\hline $3 \mathrm{~B}$ & & Inverno & VM Inverno + FFD Inverno \\
\hline
\end{tabular}

Inicialmente o modelo foi integrado por 30 dias com os campos de massa de verão e de inverno sem a forçante vento. Estes experimentos, inicializados com campos de elevação da superfície livre do nível do mar e velocidades iguais a zero, foram estabilizados e, o resultado final das simulações foram utilizados como condição inicial para os experimentos $1 \mathrm{~A}$ a $3 \mathrm{~B}$, de acordo com a sazonalidade. A estabilização destes experimentos foi analisada a partir do cálculo de energia cinética média proposto 
por Miller \& Lee (1995):

$$
\bar{K}=\frac{1}{A} \iint \bar{\rho}\left[\frac{\left(u^{2}+v^{2}\right.}{2}\right] d x d y
$$

onde, $\bar{K}$ é a energia cinética média e $A$ é a área do domínio modelado.

Os experimentos 1A e 1B foram forçados com ventos reais, para o período entre 01/01/2003 até 31/03/2003 (experimento 1A) e entre 01/07/2004 e 30/09/2004 (experimento 1B). Estes períodos foram os selecionados por serem os períodos com dados medidos disponíveis na região da PCSE.

Os experimentos 2 ( $\mathrm{A}$ e B) e 3 (A e B) foram integrados num total de 12 dias. Os dois primeiros dias foram forçados pelos ventos médios sazonais, simulando desta maneira a presença ininterrupta dos ventos provenientes do ASAS. No instante de tempo $48 \mathrm{~h}$ ocorre a entrada de FF média obtida por este estudo, sendo que neste momento os ventos que começam a ser alterados devido a este fenômeno estão na região de Imbituba (limite sul da PCSE).

A validação do BDO foi realizada da mesma forma que para o BDA: busca por dados disponíveis coletados na PCSE. Esta busca ficou centrada em dados de elevação do nível do mar em diversos pontos da costa da PCSE. Neste caso, diferentemente da validação do BDA, deu-se preferência para diferentes locais com a mesma abrangência temporal. As características, quanto à coordenadas, origem, abrangência espacial e propriedades de coleta dos dados oceanográficos obtidos estão apresentados na Tabela 3.3, e a localização geográfica na Figura 3.2 .

As séries obtidas que apresentaram intervalos de coleta inferiores à $6 \mathrm{~h}$ foram interpoladas. Os dados de elevação do nível do mar sofreram os mesmos tipos de tratamentos estatísticos descritos para os dados atmosféricos, com exceção da reamostragem, que neste caso foi realizada com intervalos regulares de $1 \mathrm{~h}$ (intervalo de tempo escolhido para compor o BDO).

Após o tratamento dos dados conforme descrito acima, a partir das simulações realizadas com o modelo hidrodinâmico foram criadas séries de tempo nos locais de coleta de dados. As séries coletadas e as do modelo hidrodinâmicos foram comparadas da mesma maneira que na confecção do BDA: por meio de análise gráfica e estatística (médias, mínimo, máximos, amplitudes e variância das séries). As séries também foram submetidas a análises estatísticas comparativas de correlação (Corr), Skill $(S)$ e o Coeficiente de Ajuste (NRMS).

Utilizamos o mesmo filtro passa-baixa descrito para as análises do BDA para a análise dos movimentos em frequência subinercial. As análises espectrais realizadas nas séries do BDO também seguiram a mesma metodologia descrita para o BDA. 


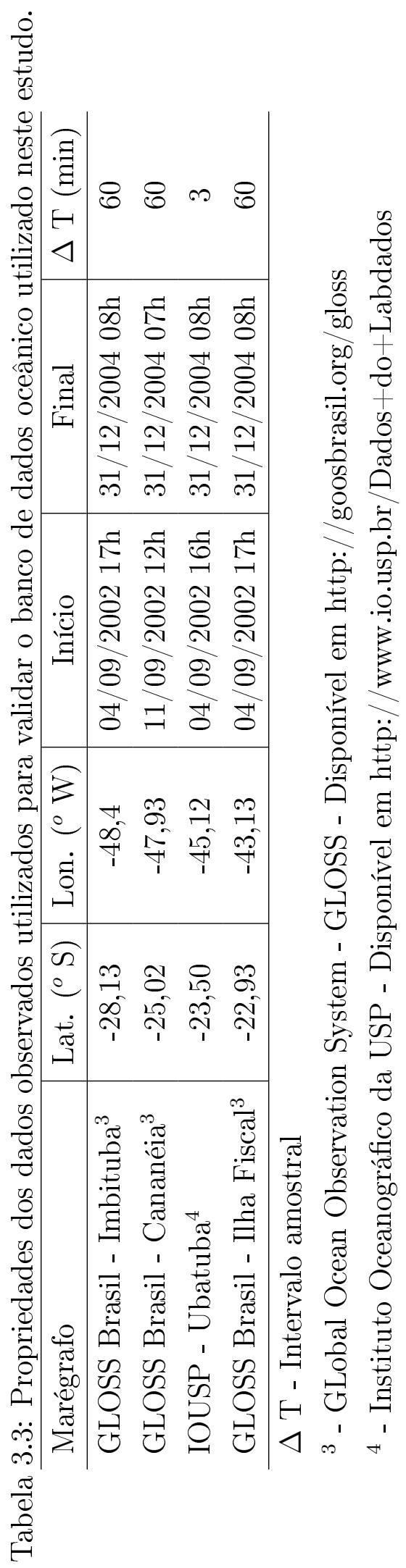




\subsection{Análises de Oscilações Subinerciais na Plata- forma Continental Sudeste}

Para a análise das OS na PCSE serão discutidos os resultados dos cenários apresentados na Tabela 3.2. Esta discussão ficou centrada nas correlações entre nível do mar e ventos, locais ou remotos. Em algumas discussões é necessária a interpretação dos resultados ao longo de radiais desde a costa até a quebra da PCSE. A localização geográfica de tais radiais é apresentada na Figura 3.6. Nesta figura também são apresentadas as direções dos eixos coordenados em várias localidades do litoral da PCSE. Este eixos são necessários para o alinhamento das componentes zonal $(u)$ e meridional $(v)$ do vento com a costa, tendo desta forma componentes perpendiculares e paralelas à costa, respectivamente.

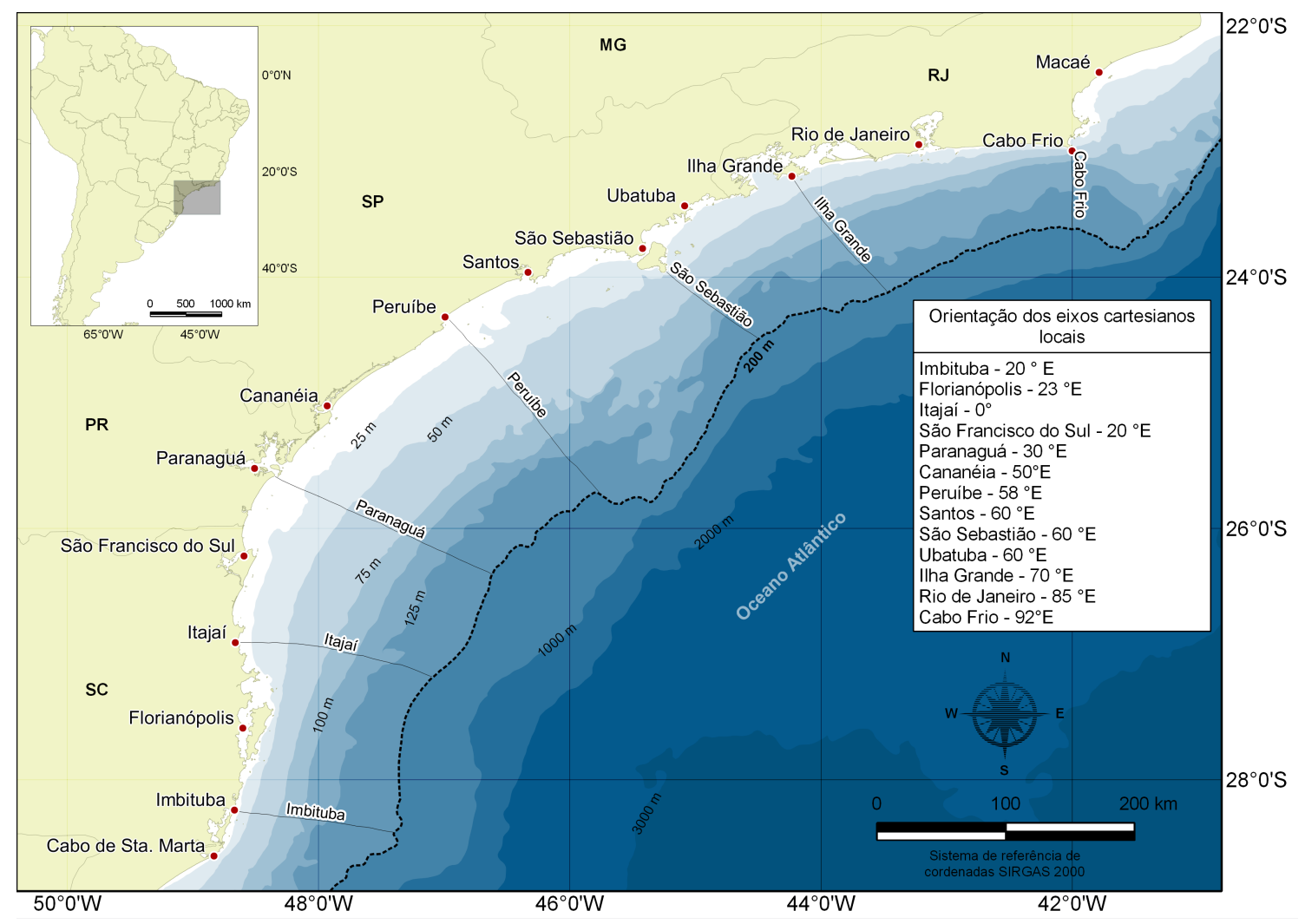

Figura 3.6: Localização das radiais quase perpendiculares à batimetria da Plataforma Continental Sudeste. No quadro, em destaque, a orientação dos eixos cartesianos locais adotados nas análises das Oscilações Subinerciais. 


\section{Capítulo 4}

\section{Resultados}

Neste capítulo são apresentados os resultados obtidos. A primeira e a segunda Seções são dedicadas à validação do BDA e BDO por meio de comparação com dados reais. A terceira Seção trás os resultados sobre o estudo desenvolvido para o entendimento do padrão atmosférico sobre a PCSE. Já as seções seguintes mostram os resultados dos cenários utilizados para se analisar as OS na PCSE.

\subsection{Validação do Banco de Dados Atmosférico}

Para validar o BDA foram colecionadas 8 séries de dados de estações, conforme apresentado na Tabela 3.1 e Figura 3.2. As séries de dados totais das componentes do vento paralela e perpendicular à costa, bem como de pressão atmosférica, aparecem nas Figuras 4.1 a 4.12 .

A análise visual comparativa entra as séries de dados totais das componentes do vento perpendicular e paralela à costa, para a região oceânica (Figuras 4.1 e 4.2), indica razoável concordância entre as séries coletadas em estações e o BDA. Em todos os locais é possível identificar que os dados coletados em estações apresentam maior variabilidade que os do BDA. Para a região costeira (Figuras 4.3 e 4.4), por serem séries mais extensas, a comparação visual fica prejudicada; contudo é possível notar novamente que as séries medidas em estações são mais variáveis que as séries do BDA. Essas variações têm alta frequência.

Para as séries de dados totais de pressão atmosférica, a análise visual entre os dados do BDA, tanto com as estações oceânicas (Figuras 4.5) quanto com as estações costeiras (Figura 4.6), indica uma boa similaridade. Diferentemente da análise visual das componentes de velocidade do vento, para a pressão atmosférica mesmo as oscilações de alta frequência são similares. Inclusive nas séries mais longas, estações costeiras (Figura 4.6), é possível identificar boa similaridade entre as séries. 


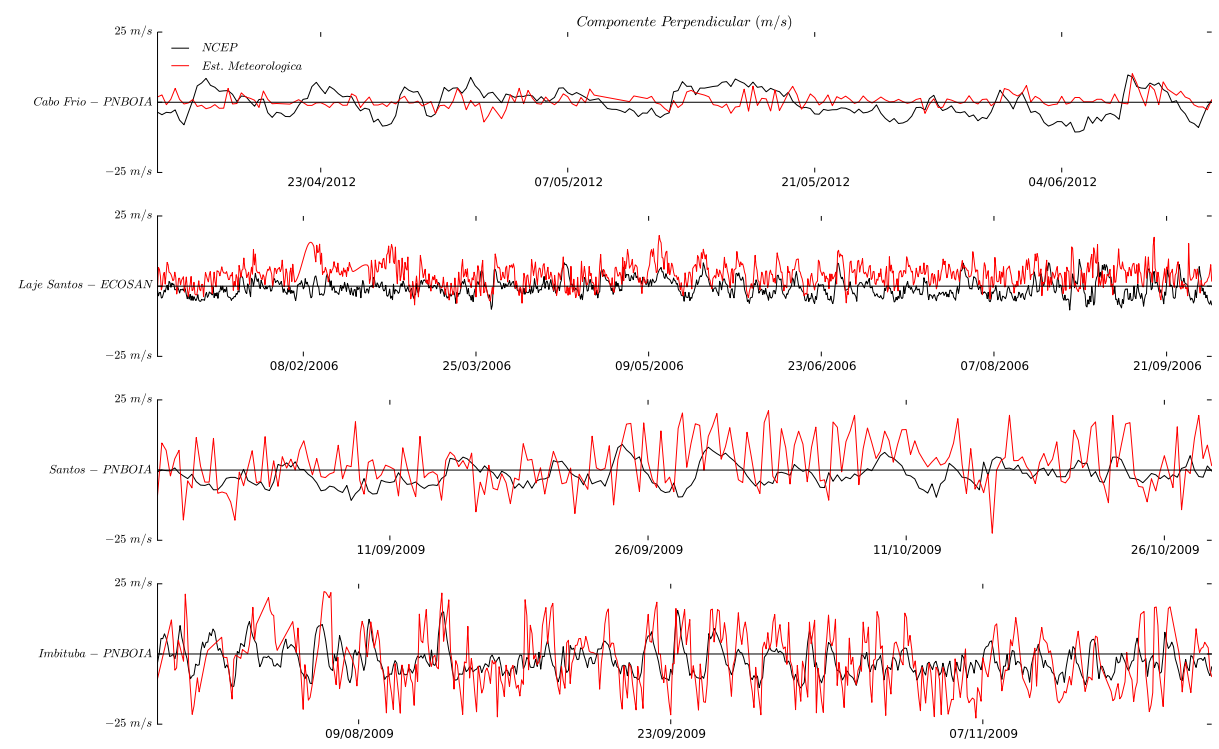

Figura 4.1: Séries de tempo dos dados totais da componente do vento perpendicular à costa do banco de dados atmosférico (linhas pretas) e dos dados coletados em estações meteorológicas oceânicas (linhas vermelhas) na Plataforma Continental Sudeste. Os locais representativos de cada série estão listados na lateral esquerda de cada painel.

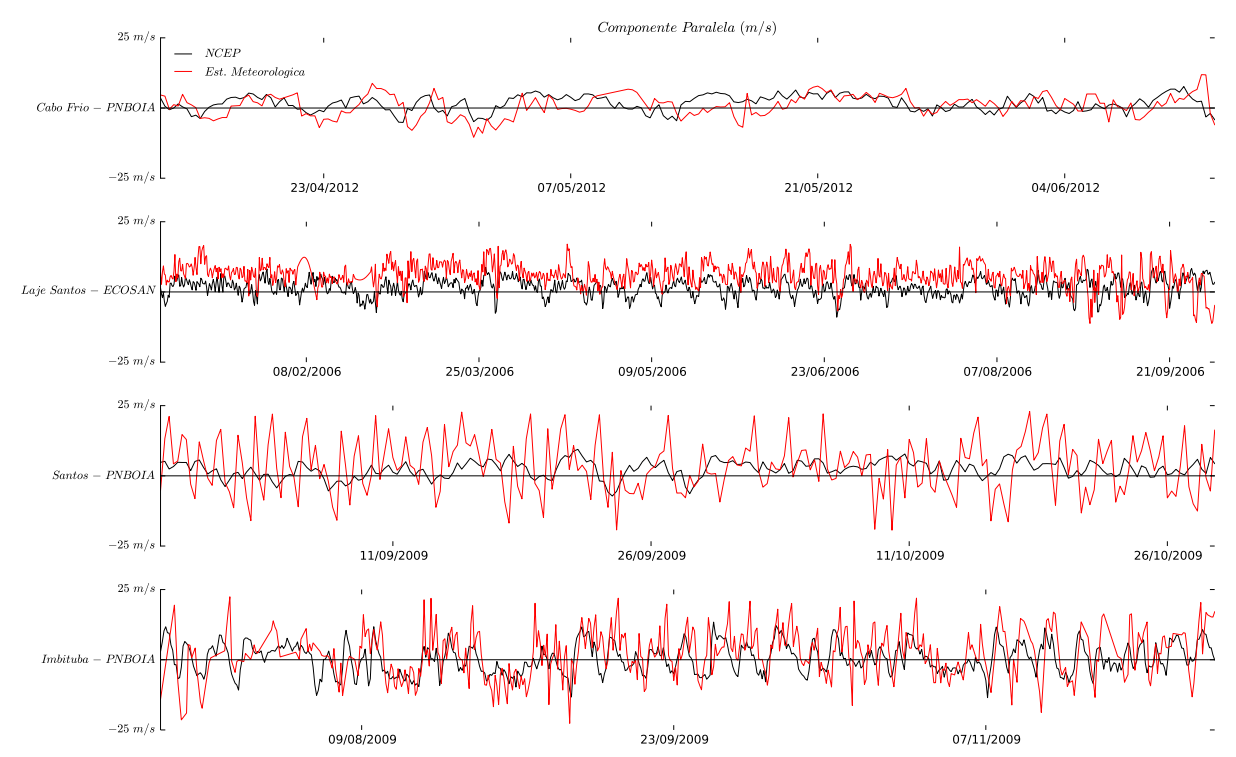

Figura 4.2: Séries de tempo dos dados totais da componente do vento paralelo à costa do banco de dados atmosférico (linhas pretas) e dados coletados em estações meteorológicas oceânicas (linhas vermelhas) na Plataforma Continental Sudeste. Os locais representativos de cada série estão listados na lateral esquerda de cada painel. 


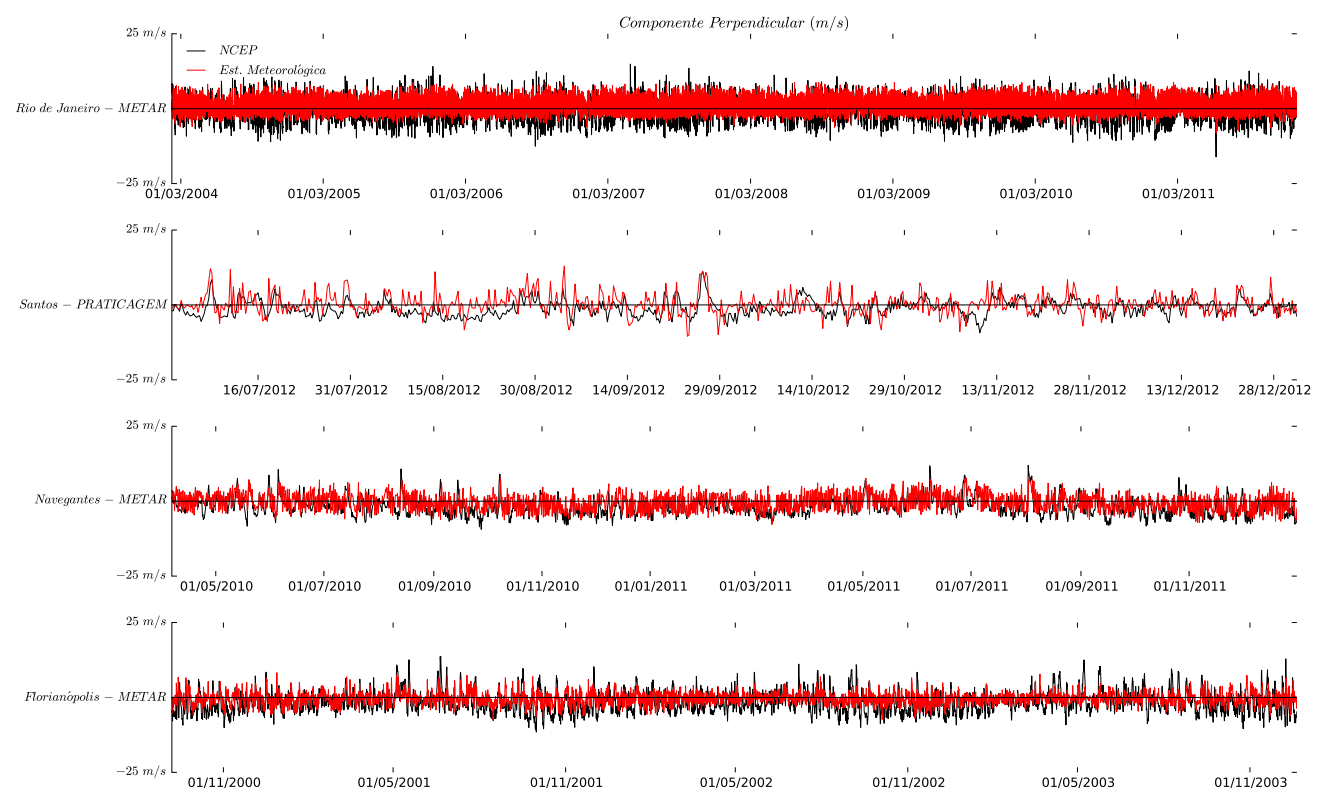

Figura 4.3: Séries de tempo dos dados totais da componente do vento perpendicular à costa do banco de dados atmosférico (linhas pretas) e dados coletados em estações meteorológicas costeiras (linhas vermelhas) na Plataforma Continental Sudeste. Os locais representativos de cada série estão listados na lateral esquerda de cada painel.

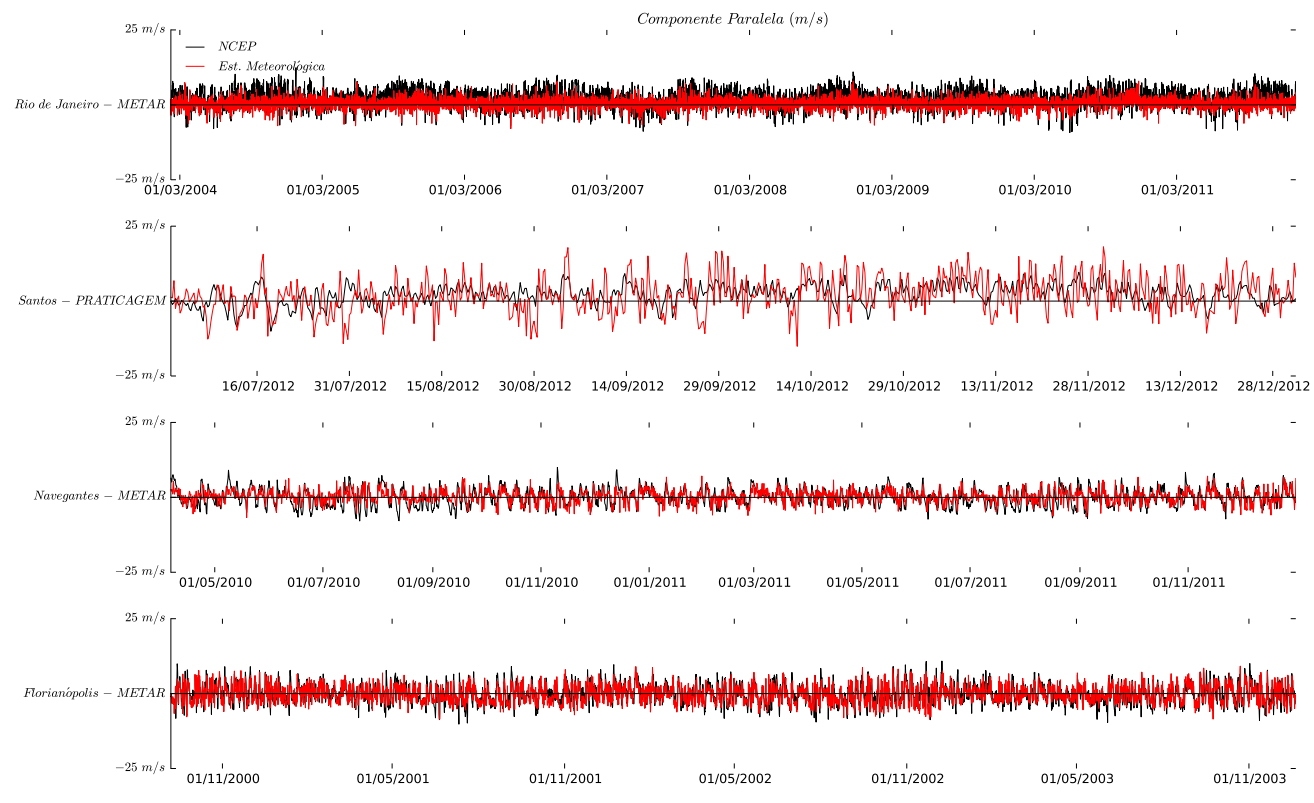

Figura 4.4: Séries de tempo dos dados totais da componente do vento paralelo à costa do banco de dados atmosférico (linhas pretas) e dados coletados em estações meteorológicas costeiras (linhas vermelhas) na Plataforma Continental Sudeste. Os locais representativos de cada série estão listados na lateral esquerda de cada painel. 


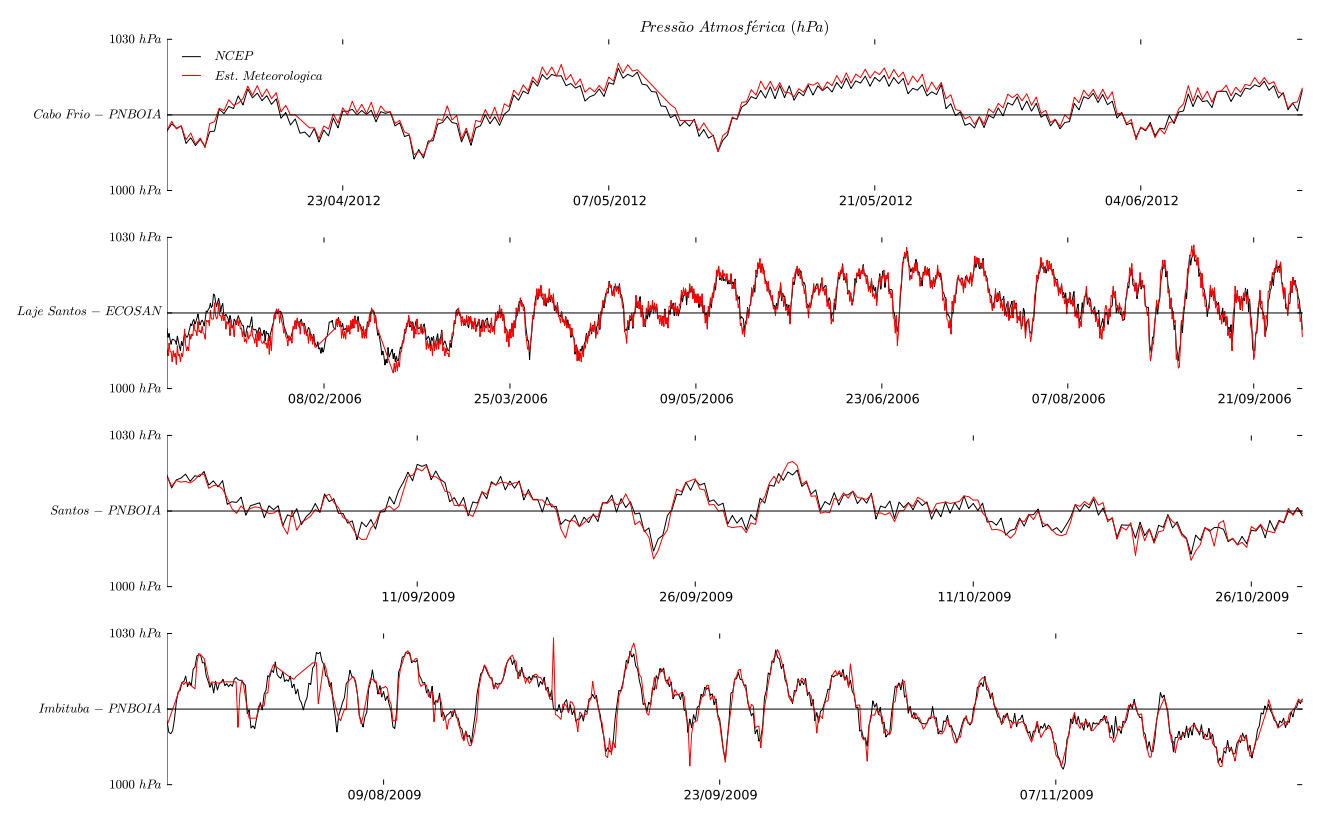

Figura 4.5: Séries de tempo dos dados totais de pressão atmosférica do banco de dados atmosférico (linhas pretas) e dados coletados em estações meteorológicas oceânicas (linhas vermelhas) na Plataforma Continental Sudeste. Os locais representativos de cada série estão listados na lateral esquerda de cada painel.

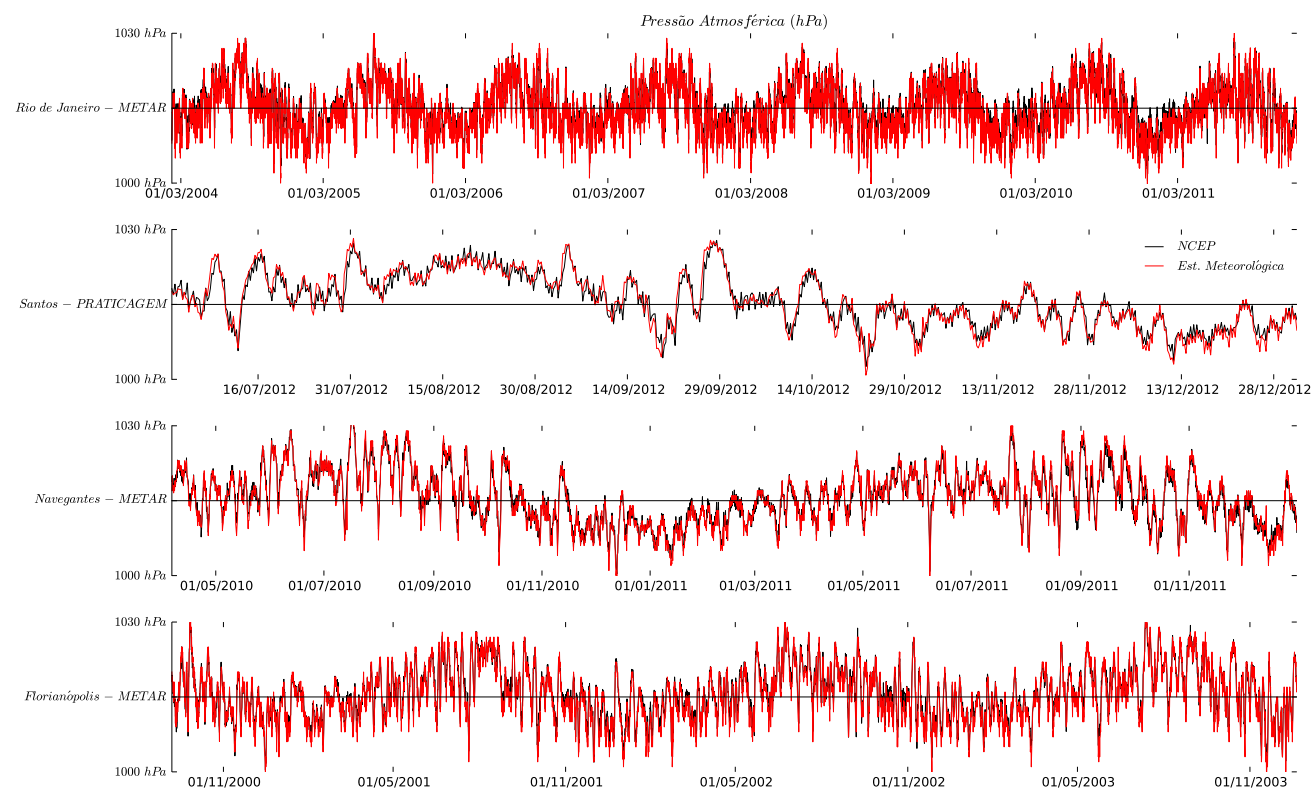

Figura 4.6: Séries de tempo dos dados totais de pressão atmosférica do banco de dados atmosférico (linhas pretas) e dados coletados em estações meteorológicas costeiras (linhas vermelhas) na Plataforma Continental Sudeste. Os locais representativos de cada série estão listados na lateral esquerda de cada painel. 
Para os dados subinerciais, a comparação visual entre as séries das componentes de velocidade do vento perpendicular e paralela à costa do BDA, tanto com as estações oceânicas (Figura 4.7 e 4.9) quanto com as estações costeiras (Figura $4.8 \mathrm{e}$ 4.10), é razoável. Na região oceânica a comparação entre os dados de estações e do BDA das componentes paralela e perpendicular à costa (Figuras 4.7 e 4.9) indica que os dados coletados em estações são mais intensos em Santos - PNBOIA e em Imbituba - PNBOIA. Em Cabo Frio - PNBOIA os extremos aparecem nas séries do BDA. Na Laje de Santos - ECOSAN os valores extremos positivos aparecem nos dados coletados em estações e os extremos negativos no BDA. Para a região costeira (Figura 4.8 e 4.10), exceto em Santos - PRATICAGEM, a comparação entre as série mostra que, em módulo, a série do BDA tem valores máximos. Em Santos PRATICAGEM os extremos positivos são superiores na série proveniente de estações e os extremos negativos na série do BDA. Ainda para a região costeira, a comparação das séries da componente paralela à costa apresenta as mesmas características da comparação das séries da componente perpendicular à costa, exceto em Santos - PRATICAGEM, que na componente paralela à costa os extremos positivos e negativos são observados na série proveniente de estações.

As comparações visuais entre os dados subinerciais de estações e do BDA de pressão atmosférica, tanto na região oceânica (Figura 4.11) quanto na região costeira (Figura 4.12 indica boa semelhança. Tanto as oscilações quanto os valores extremos são semelhantes em ambas as séries.

As Tabelas 4.1 e 4.2 mostram as análises estatísticas básicas das séries apresentadas nas Figuras 4.1 a 4.12, para as regiões oceânica e costeira, respectivamente. Da Tabela 4.1 é possível inferir que a porção subinercial do espectro é mais representativa para os dados do BDO do que para os coletados em estações, confirmando a análise visual das séries, que indicou que nas séries brutas os dados coletados em estações possuem mais variância, associadas à altas frequências, que os dados do BDA. Para a componente do vento perpendicular à costa na região oceânica, as séries do BDA indicam que em todos os locais cerca de $90 \%$ da variância é atribuída às frequências subinercias. Para as séries coletadas em estações, em Cabo Frio PNBOIA e em Santos - PRATICAGEM, estes valores são inferiores a 50\% (49 e $42 \%$, respectivamente) e na Laje de Santos - ECOSAN e em Imbituba - PNBOIA inferiores a $80 \%$ (71 e 78\%, respectivamente). Para a componente do vento paralela à costa na região oceânica, as menores variâncias explicadas pelas frequências subinerciais foram mínimas em Santos - PNBOIA, tanto nos dados do BDA (79\%) quanto na estação (37\%). Para os demais locais o BDA apresenta valores de variância atribuída à componente subinercial superior a $80 \%$ e os dados coletados em estações superiores a $70 \%$. 


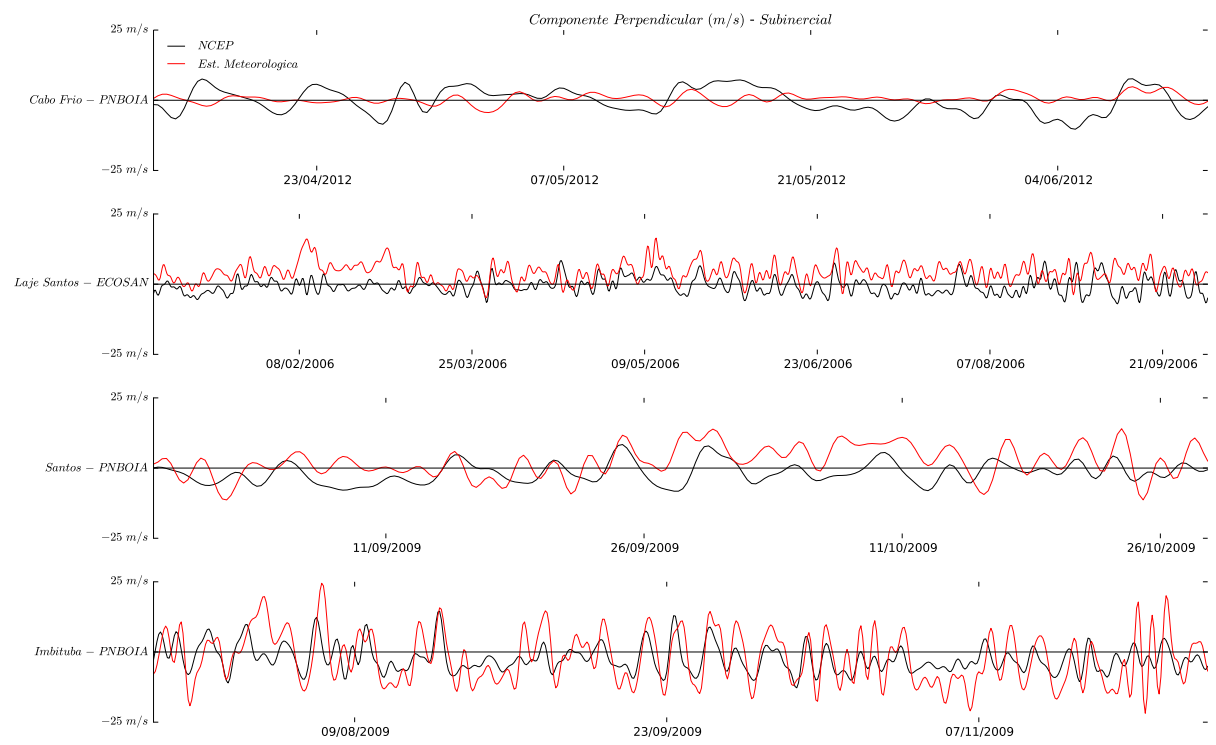

Figura 4.7: Séries de tempo dos dados subinerciais do componente do vento perpendicular à costa do banco de dados atmosférico (linhas pretas) e dados coletados em estações meteorológicas oceânicas (linhas vermelhas) na Plataforma Continental Sudeste. Os locais representativos de cada série estão listados na lateral esquerda de cada painel.

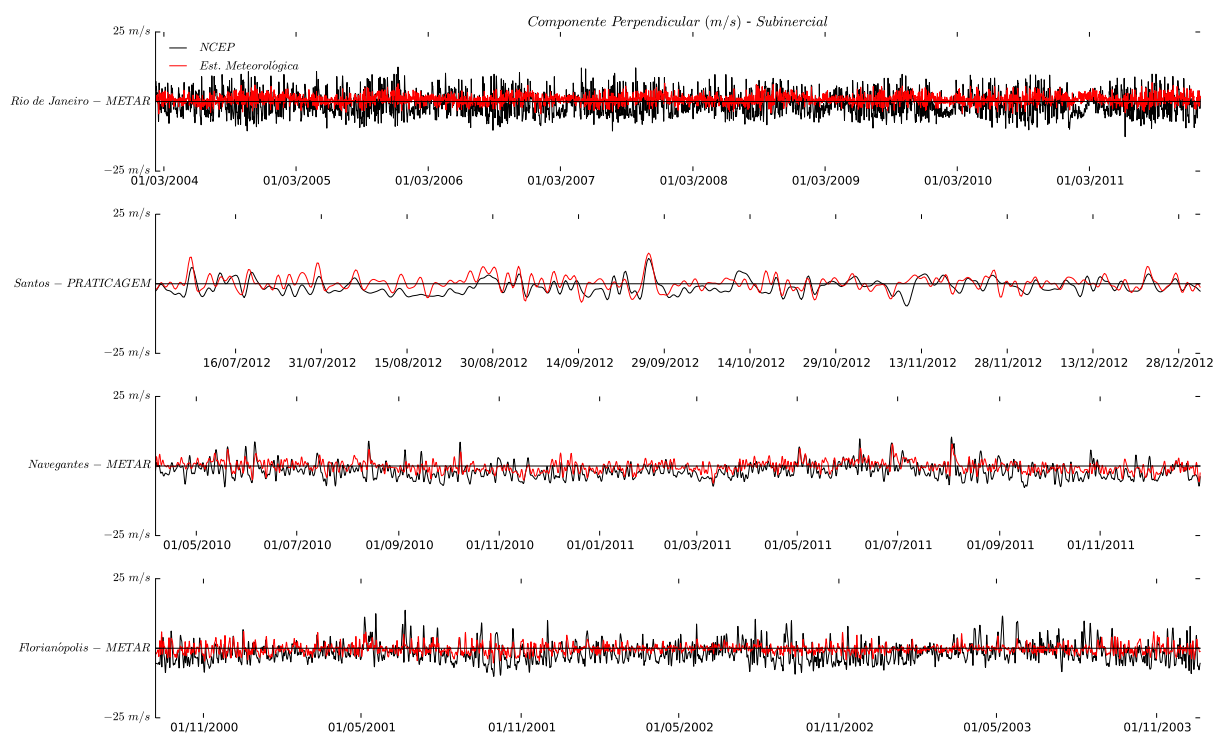

Figura 4.8: Séries de tempo dos dados subinerciais do componente do vento perpendicular à costa do banco de dados atmosférico (linhas pretas) e dados coletados em estações meteorológicas costeiras (linhas vermelhas) na Plataforma Continental Sudeste. Os locais representativos de cada série estão listados na lateral esquerda de cada painel. 


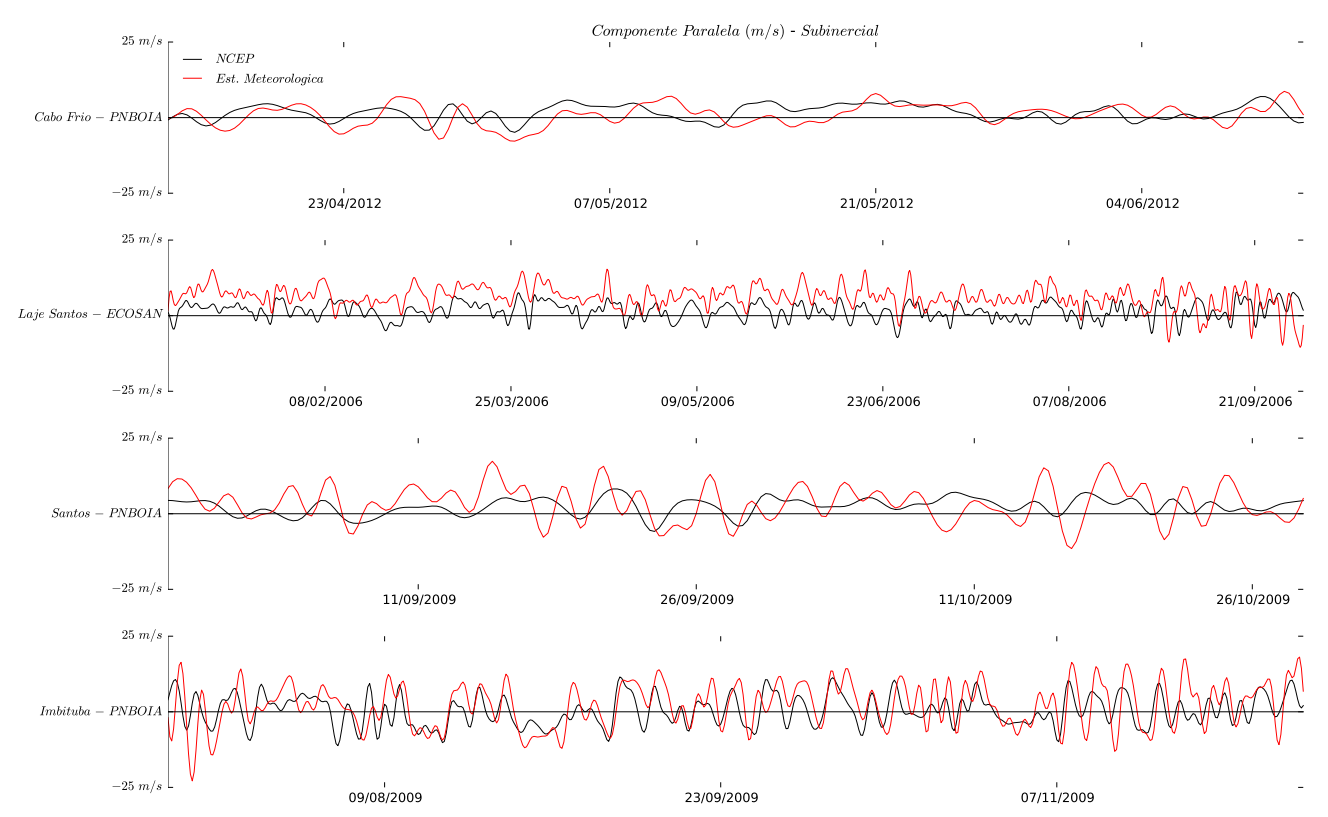

Figura 4.9: Séries de tempo dos dados subinerciais do componente do vento paralelo à costa do banco de dados atmosférico (linhas pretas) e dados coletados em estações meteorológicas oceânicas (linhas vermelhas) na Plataforma Continental Sudeste. Os locais representativos de cada série estão listados na lateral esquerda de cada painel.

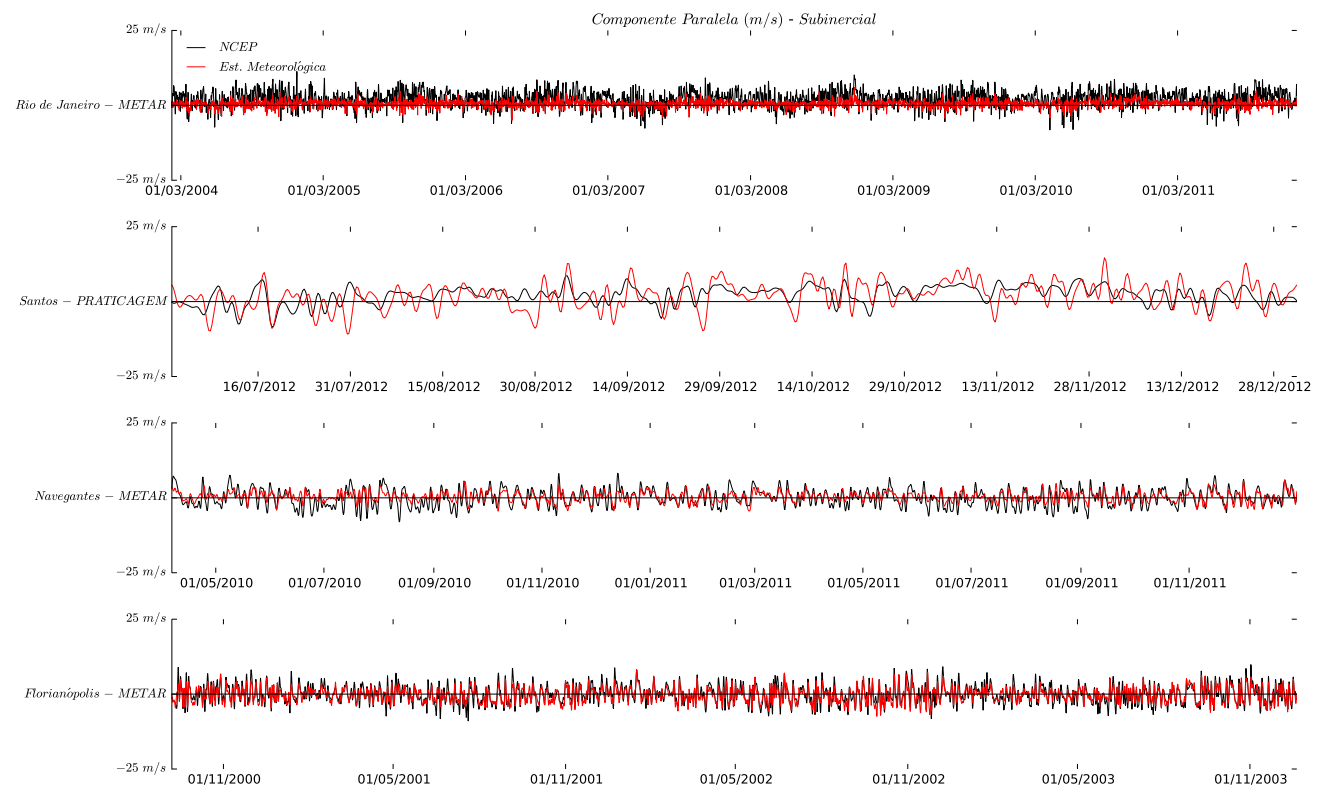

Figura 4.10: Séries de tempo dos dados subinerciais do componente do vento paralelo à costa do banco de dados atmosférico (linhas pretas) e dados coletados em estações meteorológicas costeiras (linhas vermelhas) na Plataforma Continental Sudeste. Os locais representativos de cada série estão listados na lateral esquerda de cada painel. 


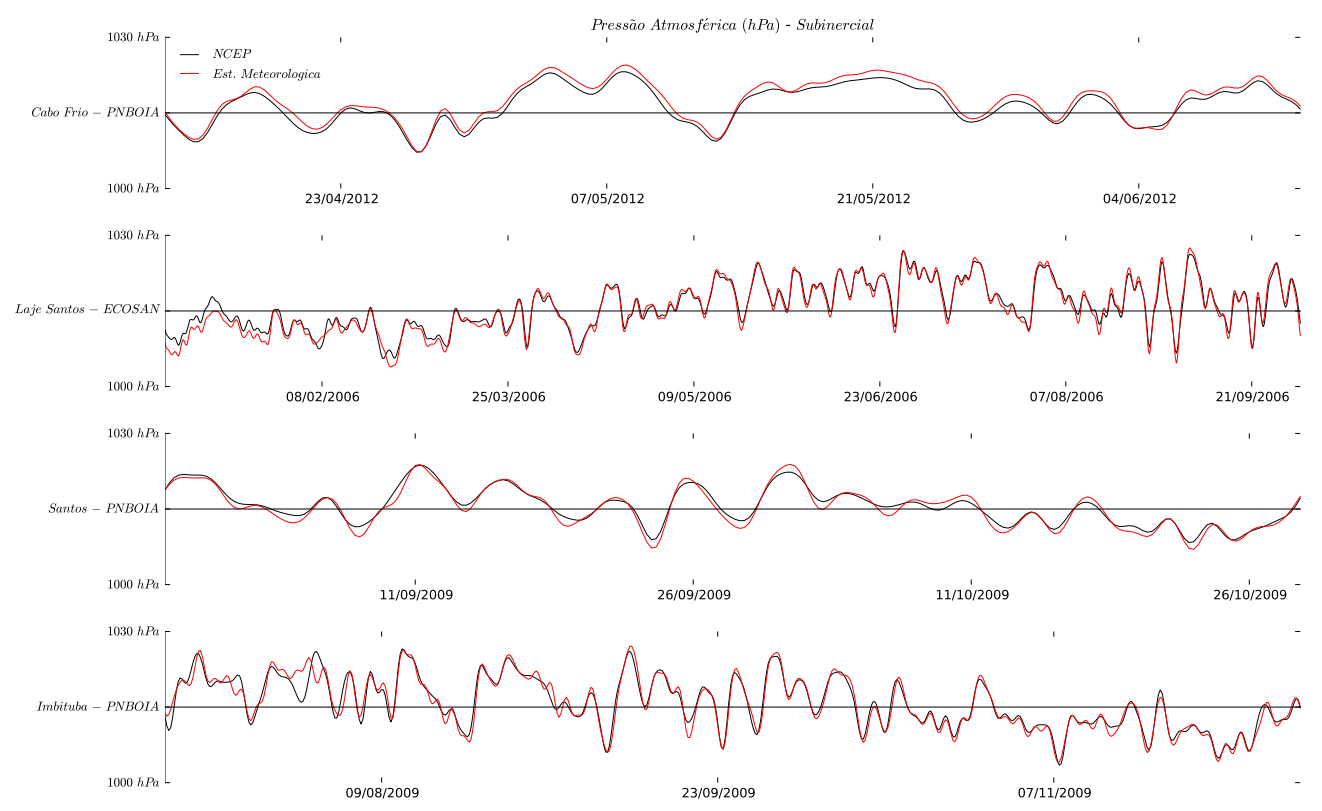

Figura 4.11: Séries de tempo dos dados subinerciais de pressão atmosférica do banco de dados atmosférico (linhas pretas) e dados coletados em estações meteorológicas oceânicas (linhas vermelhas) na Plataforma Continental Sudeste. Os locais representativos de cada série estão listados na lateral esquerda de cada painel.

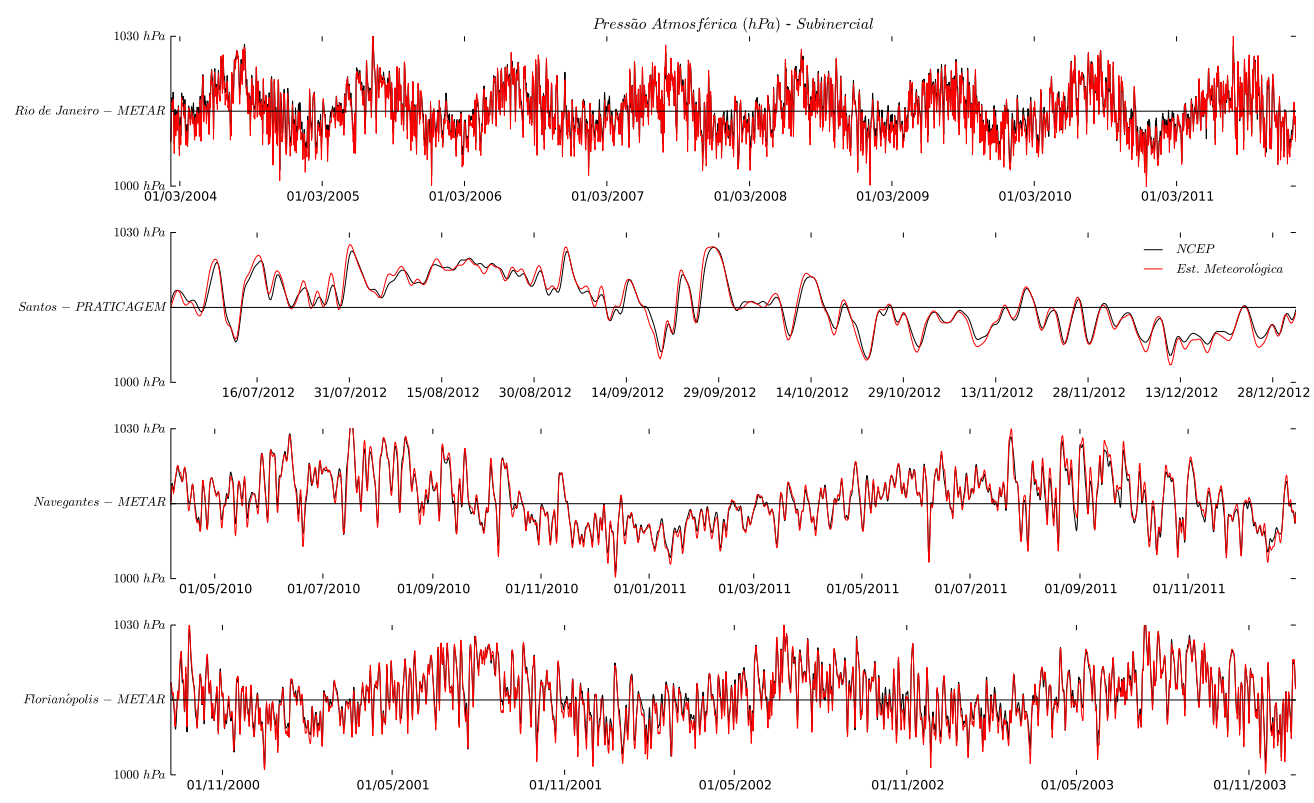

Figura 4.12: Séries de tempo dos dados subinerciais de pressão atmosférica do banco de dados atmosférico (linhas pretas) e dados coletados em estações meteorológicas costeiras (linhas vermelhas) na Plataforma Continental Sudeste. Os locais representativos de cada série estão listados na lateral esquerda de cada painel. 
Tabela 4.1: Estimativas estatísticas dos dados coletados em estações meteorológicas oceânicas (coletado) e do banco de dados atmosférico (NCEP-DOE AMIP II). Per. é a componente do vento perpendicular à costa; Par. é a componente do vento paralela à costa; Pressão atm. é a pressão atmosférica.

\begin{tabular}{|c|c|c|c|c|c|c|}
\hline \multirow{3}{*}{$\begin{array}{l}\text { Origem do dado } \\
\text { Parâmetro }\end{array}$} & \multicolumn{3}{|c|}{ NCEP } & \multicolumn{3}{|c|}{ Coletado } \\
\hline & \multicolumn{2}{|c|}{ Vento $(\mathrm{m} / \mathrm{s})$} & \multirow{2}{*}{$\begin{array}{c}\text { Pressão } \\
\text { atm. (hPa) }\end{array}$} & \multicolumn{2}{|c|}{$\operatorname{Vento}(\mathrm{m} / \mathrm{s})$} & \multirow{2}{*}{$\begin{array}{c}\text { Pressão } \\
\text { atm. (hPa) }\end{array}$} \\
\hline & Per. & Par. & & Per. & Par. & \\
\hline Localização & \multicolumn{6}{|c|}{ Cabo Frio - PNBOIA } \\
\hline Média & $-0,3$ & 1,7 & 1016,5 & 0,6 & 1 & 1017,4 \\
\hline Mínimo & $-10,6$ & $-5,1$ & 1006,2 & -7 & $-10,4$ & 1007,0 \\
\hline Máximo & 9,7 & 7,7 & 1024,3 & 10,2 & 11,9 & 1025,2 \\
\hline Amplitude & 20,3 & 12,8 & 18,0 & 17,2 & 22,3 & 18,2 \\
\hline Variância & 21,6 & 7,7 & 15,1 & 5,3 & 15 & 16,9 \\
\hline Variância - subinercial & 20 & 6,5 & 14,1 & 2,6 & 11,9 & 15,9 \\
\hline Porcentagem subinercial & 92,6 & 85,1 & 93,7 & 49 & 79,2 & 94,2 \\
\hline Localização & \multicolumn{6}{|c|}{ Laje de Santos - ECOSAN } \\
\hline Média & $-0,7$ & 1,6 & 1016,0 & $-0,8$ & 1,1 & 1010,6 \\
\hline Mínimo & $-8,5$ & $-9,0$ & 1004,7 & $-11,7$ & $-16,2$ & 998,1 \\
\hline Máximo & 9,6 & 8,8 & 1027,2 & 13,1 & 12,0 & 1023,5 \\
\hline Amplitude & 18,1 & 17,8 & 22,5 & 24,8 & 28,2 & 25,4 \\
\hline Variância & 9,4 & 9,3 & 21,3 & 16,1 & 19,4 & 25,3 \\
\hline Variância - subinercial & 8,2 & 7,8 & 20,7 & 11,4 & 14,1 & 24,3 \\
\hline Porcentagem subinercial & 88,1 & 83,5 & 97,1 & 70,9 & 72,9 & 95,8 \\
\hline Localização & \multicolumn{6}{|c|}{ Santos - PNBOIA } \\
\hline Média & $-1,7$ & 2,4 & 1015,5 & 2,4 & 3,5 & 1015,2 \\
\hline Mínimo & $-10,8$ & $-7,2$ & 1006,4 & $-22,5$ & $-19,4$ & 1005,2 \\
\hline Máximo & 9,1 & 9,4 & 1024,3 & 21,2 & 22,9 & 1024,8 \\
\hline Amplitude & 19,9 & 16,6 & 17,8 & 43,7 & 42,3 & 19,6 \\
\hline Variância & 15,1 & 9,1 & 13,5 & 71,8 & 93,9 & 15,7 \\
\hline Variância - subinercial & 13,4 & 7,2 & 12,2 & 30,0 & 34,3 & 14,7 \\
\hline Porcentagem subinercial & 89,1 & 79,2 & 90,9 & 41,8 & 36,5 & 93,6 \\
\hline Localização & \multicolumn{6}{|c|}{ Imbituba - PNBOIA } \\
\hline Média & $-2,4$ & 0,4 & 1015,8 & $-2,1$ & 2,3 & 1015,7 \\
\hline Mínimo & $-12,1$ & $-13,5$ & 1003,1 & $-22,8$ & $-22,7$ & 1003,6 \\
\hline Máximo & 15,5 & 13,4 & 1026,7 & 22,2 & 22,4 & 1029,1 \\
\hline Amplitude & 27,7 & 26,9 & 23,7 & 45,0 & 45,1 & 25,5 \\
\hline Variância & 25,1 & 27,2 & 25,3 & 101,7 & 68,8 & 27,9 \\
\hline Variância - subinercial & 22,7 & 24,8 & 24,6 & 79,8 & 51,3 & 26,9 \\
\hline Porcentagem subinercial & 90,3 & 91,3 & 97,4 & 78,5 & 74,5 & 96,3 \\
\hline
\end{tabular}


Tabela 4.2: Estimativas estatísticas dos dados coletados em estações meteorológicas costeiras (coletado) e do banco de dados atmosférico (NCEP-DOE AMIP II). Per. é a componente do vento perpendicular à costa; Par. é a componente do vento paralela à costa; Pressão atm. é a pressão atmosférica

\begin{tabular}{|c|c|c|c|c|c|c|}
\hline \multirow{3}{*}{$\begin{array}{l}\text { Origem do dado } \\
\text { Parâmetro }\end{array}$} & \multicolumn{3}{|c|}{ NCEP } & \multicolumn{3}{|c|}{ Coletado } \\
\hline & \multicolumn{2}{|c|}{ Vento $(\mathrm{m} / \mathrm{s})$} & \multirow{2}{*}{$\begin{array}{l}\text { Pressão } \\
\text { atm. (hPa) }\end{array}$} & \multicolumn{2}{|c|}{ Vento $(\mathrm{m} / \mathrm{s})$} & \multirow{2}{*}{$\begin{array}{l}\text { Pressão } \\
\text { atm. (hPa) }\end{array}$} \\
\hline & & Par. & & Per. & Par. & \\
\hline Localização & \multicolumn{6}{|c|}{ Rio de Janeiro - METAR } \\
\hline Média & $-0,7$ & 2,1 & 1015,5 & 0,8 & 0,5 & 1014,7 \\
\hline Mínimo & $-16,1$ & $-9,3$ & 1000,4 & $-8,2$ & $-7,9$ & 997,0 \\
\hline Máximo & 14,9 & 12,4 & 1030,8 & 8,7 & 7,9 & 1031,0 \\
\hline Amplitude & 31,0 & 21,7 & 30,3 & 16,9 & 15,9 & 34,0 \\
\hline Variância & 16,4 & 8,1 & 20,3 & 8,5 & 2,5 & 24,3 \\
\hline Variância - subinercial & 14,6 & 6,5 & 19,4 & 2,3 & 1,2 & 22,9 \\
\hline Porcentagem subinercial & 89,0 & 80,8 & 95,3 & 26,7 & 47,7 & 94,2 \\
\hline Localização & \multicolumn{6}{|c|}{ Santos - PRATICAGEM } \\
\hline Média & $-1,1$ & 2,2 & 1015,7 & 0,3 & 2,0 & 1015,7 \\
\hline Mínimo & $-9,3$ & $-10,1$ & 1002,5 & $-10,5$ & $-15,1$ & 1000,8 \\
\hline Máximo & 11,1 & 9,6 & 1027,8 & 13,0 & 18,1 & 1028,2 \\
\hline Amplitude & 20,4 & 19,7 & 25,3 & 23,4 & 33,2 & 27,4 \\
\hline Variância & 7,3 & 10,4 & 26,4 & 11,5 & 35,6 & 30,7 \\
\hline Variância - subinercial & 6,1 & 8,5 & 24,9 & 6,2 & 19,4 & 29,7 \\
\hline Porcentagem subinercial & 83,9 & 81,8 & 94,5 & 53,6 & 54,5 & 96,8 \\
\hline Localização & \multicolumn{6}{|c|}{ Navegantes - METAR } \\
\hline Média & $-1,7$ & 0,0 & 1015,8 & $-0,1$ & 0,4 & 1015,8 \\
\hline Mínimo & $-9,4$ & $-7,9$ & 1000,3 & $-7,7$ & $-6,8$ & 999,0 \\
\hline Máximo & 11,9 & 10,0 & 1032,5 & 8,0 & 7,1 & 1033,0 \\
\hline Amplitude & 21,3 & 17,9 & 32,1 & 15,7 & 13,9 & 34,0 \\
\hline Variância & 8,1 & 8,7 & 27,0 & 8,1 & 4,6 & 30,6 \\
\hline Variância - subinercial & 7,1 & 7,9 & 25,8 & 3,3 & 2,8 & 29,4 \\
\hline Porcentagem subinercial & 87,7 & 91,4 & 95,6 & 40,9 & 60,9 & 96,2 \\
\hline Localização & \multicolumn{6}{|c|}{ Florianópolis - METAR } \\
\hline Média & $-1,6$ & $-0,1$ & 1015,9 & $-0,2$ & $-0,2$ & 1015,4 \\
\hline Mínimo & $-11,6$ & $-10,2$ & 1000,3 & $-7,3$ & $-8,5$ & 998,0 \\
\hline Máximo & 13,7 & 10,9 & 1031,9 & 8,2 & 9,2 & 1033,0 \\
\hline Amplitude & 25,3 & 21,1 & 31,6 & 15,6 & 17,7 & 35,0 \\
\hline Variância & 12,1 & 10,1 & 24,5 & 4,1 & 8,1 & 29,1 \\
\hline Variância - subinercial & 11,0 & 8,7 & 23,9 & 2,4 & 5,6 & 28,0 \\
\hline Porcentagem subinercial & 90,6 & 85,9 & 97,4 & 58,3 & 68,7 & 96,1 \\
\hline
\end{tabular}


Nas séries em região oceânica do BDA as frequências subinerciais são mais significativas para a variância total na componente do vento perpendicular à costa (exceto em Imbituba - PNBOIA) e nas séries das estações mais importante na componente do vento paralela à costa em Cabo Frio - PNBOIA e na Laje de Santos - ECOSAN, e mais importante na componente do vento perpendicular à costa em Santos - PNBOIA e em Imbituba - PNBOIA. Tanto as séries em região oceânica de pressão atmosférica do BDA quanto das estações têm mais de $90 \%$ da variâncias atribuídas às frequências subinercias.

Na região costeira (Tabela 4.2), novamente as séries coletadas em estações apresentam menor porcentagem de variância atribuída à banda subinercial do espectro quanto comparado aos valores calculados para as séries do BDA. As porcentagens de variância explicada na região costeira pelas frequências subinerciais na componente do vento perpendicular (paralela) à costa é superior a 80\% (80\%) nas séries do BDA, enquanto que para os dados coletados em estações são sempre inferiores a $60 \%$ (70\%). Nas séries coletadas em estações (BDA), as frequências subinerciais são mais importantes para a componente do vento paralela (perpendicular) à costa. As séries da componente do vento paralela à costa coletada em estações mostram que as frequências subinerciais são mais importantes para a variância total na porção sul (Florianópolis - METAR, 69\%) do que na porção norte (Rio de Janeiro - METAR $48 \%$ ). Este fato também foi observado para as séries do BDA contudo, em Navegantes - METAR (92\%) esta importância é mais acentuada que em Florianópolis METAR (86\%). Para a pressão atmosférica, as estimativas estatísticas corroboram as similaridades entre as séries do BDA e àquelas coletadas em estações. Novamente, as porcentagens da variância atribuídas às frequências subinercias são similares para as séries coletadas em estações e as do BDA e em todos os locais mais de $90 \%$ da variância da pressão atmosférica é atribuída às frequências subinerciais.

Para quantificar a similaridade estatística entre as séries coletadas em estações e as que fazem parte do BDA, calculamos a correlação, skill e o NRMS (Tabela 4.3). Para as séries totais, as correlações para as componentes dos ventos foram todas inferiores a 0,50. Imbituba - PNBOIA foi a localidade que apresentou a melhor correlação entre as séries (0,44 e 0,34 para as componentes do vento perpendicular e paralelas à costa). Os menores valores foram obtidos em Santos - PNBOIA $(0,04$ e 0,05 para as componentes do vento perpendicular e paralela à costa). De modo geral as correlações na região costeira foram superiores às calculadas para a região oceânica. As correlações entre as séries de pressão atmosférica foram superiores a 0,93 em todos os locais. As séries subinercias tiveram valores de correlação superiores aos obtidos pelas séries totais, em todos os locais e em ambas as componentes do vento. Em Navegantes - METAR a correlação entre as séries da componente do vento paralela à costa foi de 0,81 . As correlações calculadas para as séries de pressão 
atmosférica foram próximas a 1,00.

Tabela 4.3: Correlação mínima com $95 \%$ de confiabilidade, skill e NRMS entre as séries coletadas por estações meteorológicas costeiras e oceânicas e o banco de dados atmosférico. Per. é a componente do vento perpendicular à costa; Par. é a componente do vento paralela à costa; Pressão atm. é a pressão atmosférica.

\begin{tabular}{|c|c|c|c|c|c|c|}
\hline & \multicolumn{3}{|c|}{ Série Total } & \multicolumn{3}{|c|}{ Série Subinercial } \\
\hline & \multicolumn{2}{|c|}{ Vento } & \multirow{2}{*}{$\begin{array}{c}\text { Pressão } \\
\text { Atm. }\end{array}$} & \multicolumn{2}{|c|}{ Vento } & \multirow{2}{*}{$\begin{array}{c}\text { Pressão } \\
\text { Atm. }\end{array}$} \\
\hline & Per. & Par. & & Per. & Par. & \\
\hline \multicolumn{7}{|c|}{ Correlação } \\
\hline Cabo Frio - PNBOIA & 0,03 & 0,13 & 0,98 & 0,04 & 0,15 & 0,99 \\
\hline Laje de Santos - ECOSAN & 0,26 & 0,19 & 0,97 & 0,30 & 0,21 & 0,98 \\
\hline Santos - PNBOIA & 0,04 & 0,05 & 0,93 & 0,22 & 0,04 & 0,98 \\
\hline Imbituba - PNBOIA & 0,44 & 0,34 & 0,93 & 0,54 & 0,44 & 0,96 \\
\hline Rio de Janeiro - METAR & 0,20 & 0,39 & 0,97 & 0,42 & 0,53 & 0,98 \\
\hline Santos - PRATICAGEM & 0,35 & 0,30 & 0,96 & 0,48 & 0,36 & 0,98 \\
\hline Navegantes - METAR & 0,31 & 0,63 & 0,98 & 0,38 & 0,81 & 0,99 \\
\hline Florianópolis - METAR & 0,38 & 0,51 & 0,98 & 0,54 & 0,69 & 0,99 \\
\hline \multicolumn{7}{|c|}{ Skill } \\
\hline Cabo Frio - PNBOIA & 0,38 & 0,53 & 0,98 & 0,35 & 0,55 & 0,98 \\
\hline Laje de Santos - ECOSAN & 0,58 & 0,53 & 0,80 & 0,62 & 0,56 & 0,80 \\
\hline Santos - PNBOIA & 0,50 & 0,32 & 0,97 & 0,62 & 0,42 & 0,99 \\
\hline Imbituba - PNBOIA & 0,61 & 0,60 & 0,97 & 0,68 & 0,68 & 0,98 \\
\hline Rio de Janeiro - METAR & 0,53 & 0,62 & 0,98 & 0,57 & 0,64 & 0,98 \\
\hline Santos - PRATICAGEM & 0,64 & 0,57 & 0,98 & 0,71 & 0,63 & 0,99 \\
\hline Navegantes - METAR & 0,66 & 0,70 & 0,99 & 0,70 & 0,77 & 0,99 \\
\hline Florianópolis - METAR & 0,58 & 0,80 & 0,98 & 0,58 & 0,89 & 0,99 \\
\hline \multicolumn{7}{|c|}{ NRMS } \\
\hline Cabo Frio - PNBOIA & 0,29 & 0,19 & 0,06 & 0,51 & 0,23 & 0,06 \\
\hline Laje de Santos - ECOSAN & 0,17 & 0,17 & 0,22 & 0,17 & 0,16 & 0,23 \\
\hline Santos - PNBOIA & 0,22 & 0,24 & 0,07 & 0,27 & 0,21 & 0,05 \\
\hline Imbituba - METAR & 0,19 & 0,18 & 0,07 & 0,16 & 0,16 & 0,05 \\
\hline Rio de Janeiro - METAR & 0,28 & 0,19 & 0,04 & 0,34 & 0,24 & 0,04 \\
\hline Santos - PRATICAGEM & 0,15 & 0,17 & 0,05 & 0,16 & 0,16 & 0,04 \\
\hline Navegantes - METAR & 0,22 & 0,19 & 0,03 & 0,19 & 0,19 & 0,03 \\
\hline Florianópolis - METAR & 0,24 & 0,14 & 0,04 & 0,29 & 0,11 & 0,03 \\
\hline
\end{tabular}


Analisando-se o skill calculado para comparar as séries totais, apenas em Cabo Frio - PNBOIA - componente do vento perpendicular à costa, Santos - PNBOIA - componente do vento paralela à costa, os valores foram inferiores a 0,50 . Para a pressão atmosférica foram obtidos valores superiores à 0,97 em todas as estações, exceto para a Laje de Santos - ECOSAN que obteve 0,80. Para os dados subinerciais, exceto para a componente do vento perpendicular à costa em Cabo Frio PNBOIA, todas séries tiveram skill superior aos obtidos nas séries totais. Os valores de skill para a pressão atmosférica são idênticos em praticamente todos os locais nas comparações entre as séries totais e subinerciais.

Para o NRMS, tanto para as séries totais quanto subinerciais, apenas a componente do vento perpendicular à costa (subinercial) em Cabo Frio - PNBOIA obteve erro maior que $50 \%$. Em todas as outras localizações e propriedades o valor máximo obtido para o NRMS foi de $34 \%$ (componente do vento perpendicular à costa - subinercial - no Rio de Janeiro - METAR). Com exceção de Imbituba - PNBOIA, as séries do BDA são mais similares às das coletadas em estações na região costeira. Também, as comparações das séries da região centro-norte da PCSE mostraram valores estatísticos comparativos inferiores às séries da região sul da PCSE.

\subsection{Validação do Banco de Dados Oceânico}

Antes de apresentar os resultados de validação do BDO, a Figura 4.13 mostra a variação da energia cinética média dos experimentos utilizados para aquecimento do modelo, que foi idêntica para o verão e inverno. Nesta Figura são apresentados os valores obtidos para as $350 \mathrm{~h}$ horas inicias de simulação (os experimentos foram integrados por 30 dias). Observa-se que ocorre estabilização do modelo em aproximadamente $190 \mathrm{~h}$. Ao final dos 30 dias de simulação os campos gerados foram utilizados como condição inicial para os Experimentos 1A a 3B.

A variação temporal da elevação total da superfície livre do mar modelada nos Experimentos 1A (forçado por ventos reais de verão) e 1B (forçado por ventos reais de inverno) comparativamente com os dados coletados em marégrafos, é apresentada nas Figuras 4.14 e 4.15, respectivamente. Tanto em período de verão quanto de inverno as séries modeladas e observadas são semelhantes. Em ambas é possível identificar a variação entre períodos de sizígia e quadratura, com menores amplitudes para Imbituba - GLOSS Brasil e maiores para Cananéia - GLOSS Brasil. Para o inverno as discrepâncias entre as séries modeladas e observadas são maiores.

As séries subinerciais obtidas nos Experimentos 1A (Figura 4.16) e 1B (Figura 4.17) apresentaram alguma correlação visual com as séries observadas. Períodos com maiores variações do nível do mar são próximos em ambas as séries, com tendências a maiores amplitudes para as séries modeladas. Tanto para o verão quanto para o 
inverno, menores amplitudes foram observadas na série modelada no local Imbituba - GLOSS Brasil, quando comparado aos dados observados. Nos demais locais as amplitudes são semelhantes.

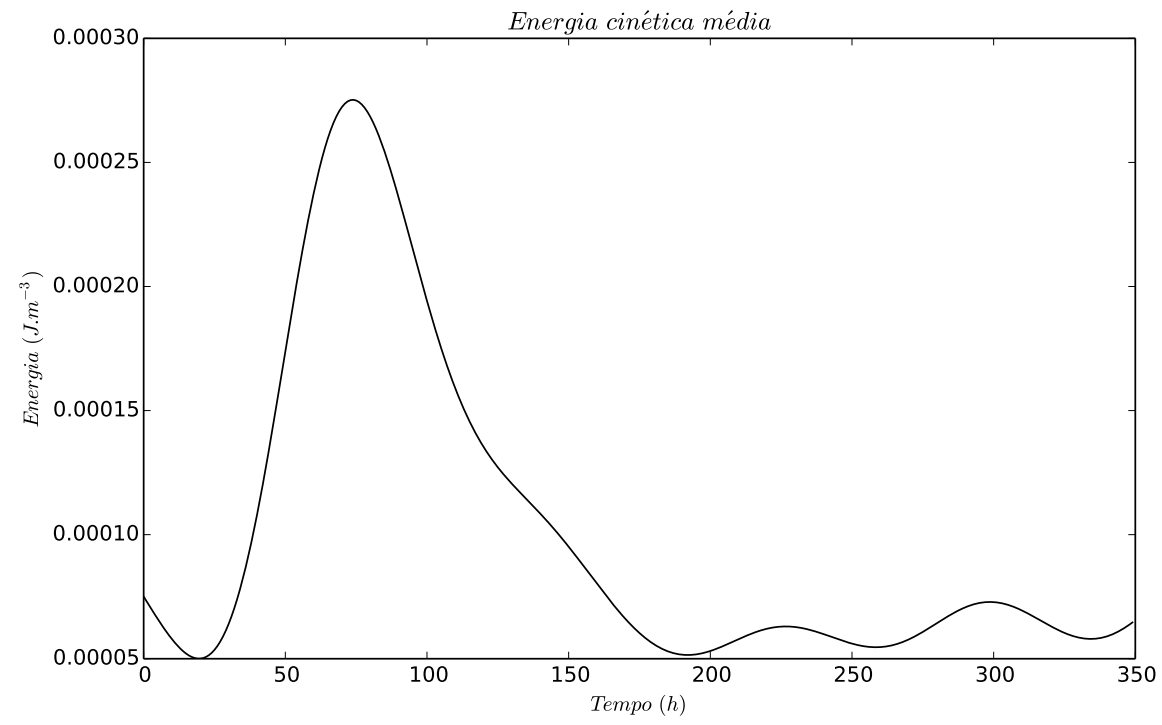

Figura 4.13: Energia cinética média para as simulações de aquecimento do modelo numérico. São apresentados somente os resultados para as $350 \mathrm{~h}$ iniciais de simulação.

A Tabela 4.4 mostra resultado de estimativas estatísticas das séries modeladas (Experimentos 1A e 1B) e medidas em marégrafos, em período de verão e inverno. Estas estimativas mostram que os valores máximo, mínimo, médio, de amplitude e variância das séries totais são próximos entre as séries modeladas e medidas. Para a banda subinercial, as variâncias estimadas são semelhantes entre as séries. As porcentagens de variância explicadas pelas OS são maiores nos dados modelados no Rio de Janeiro - GLOSS Brasil e Ubatuba - IOUSP, tanto no verão quanto no inverno. Em Cananéia - GLOSS Brasil, no verão a porcentagem de variância explicada pelas frequências subinerciais são semelhantes nas séries modeladas e medidas, e no período de inverno as séries modeladas apresentam maior porcentagem atribuída à banda subinercial do que as séries observadas. Em Imbituba - GLOSS Brasil, os dados coletados possuem maior porcentagem de variância explicada pelas frequências subinerciais do que os dados modelados, em ambas estações do ano. 


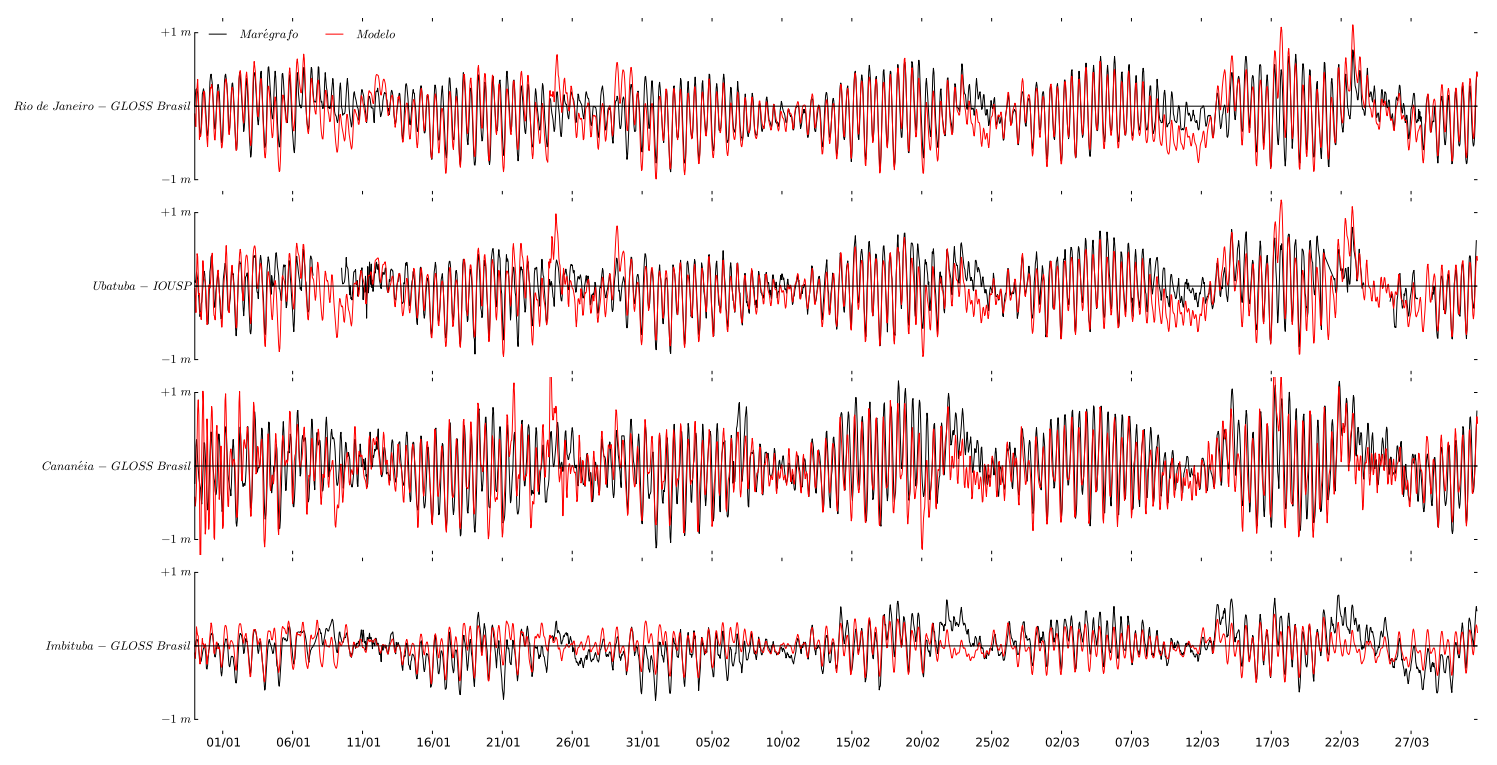

Figura 4.14: Séries de tempo de elevação total da superfície livre do mar modelada (Experimento 1A - linha preta) e observada (linha vermelha) durante o verão de 2003. Os locais representativos de cada série estão listados na lateral esquerda de cada painel.

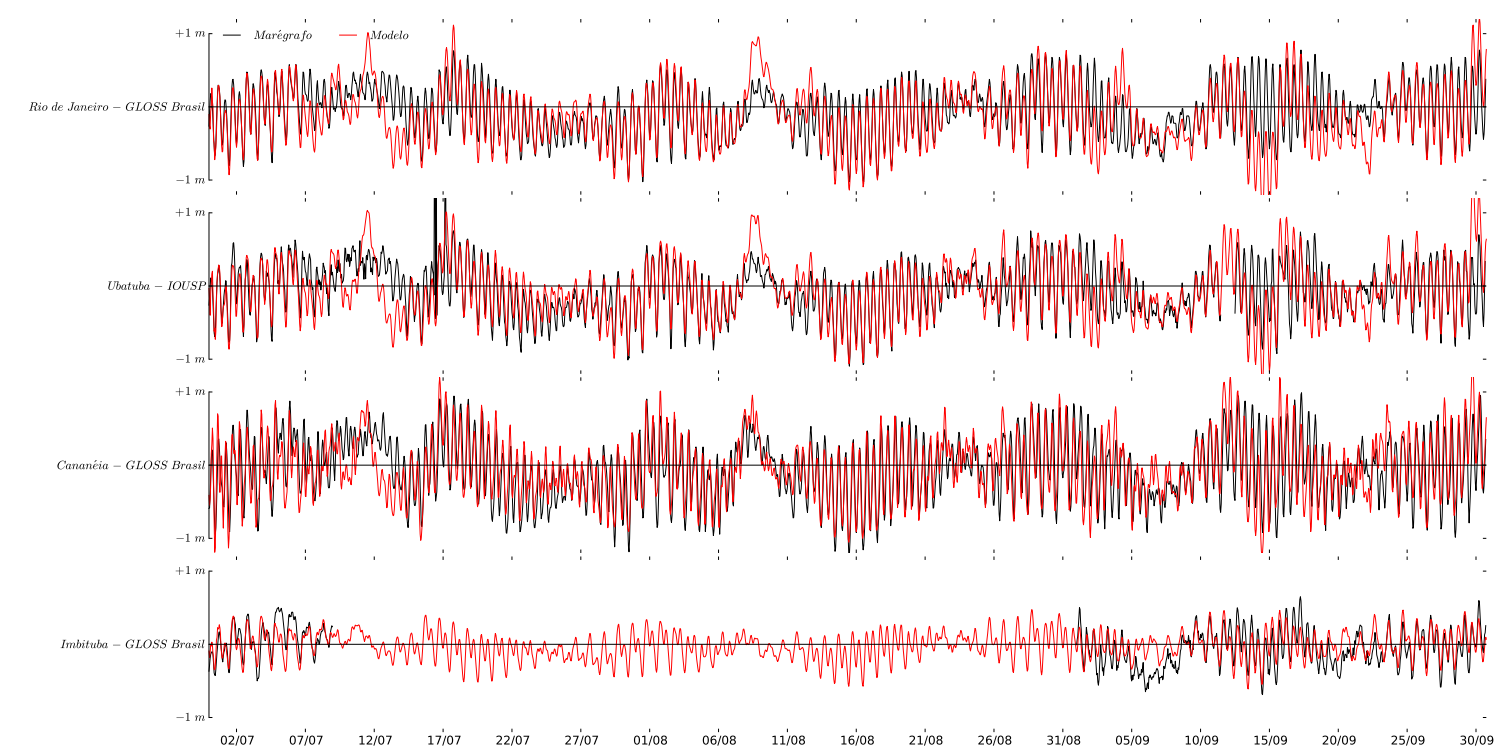

Figura 4.15: Séries de tempo de elevação total da superfície livre do mar modelada (Experimento 1B - linha preta) e observada (linha vermelha) durante o inverno de 2004. Os locais representativos de cada série estão listados na lateral esquerda de cada painel. 


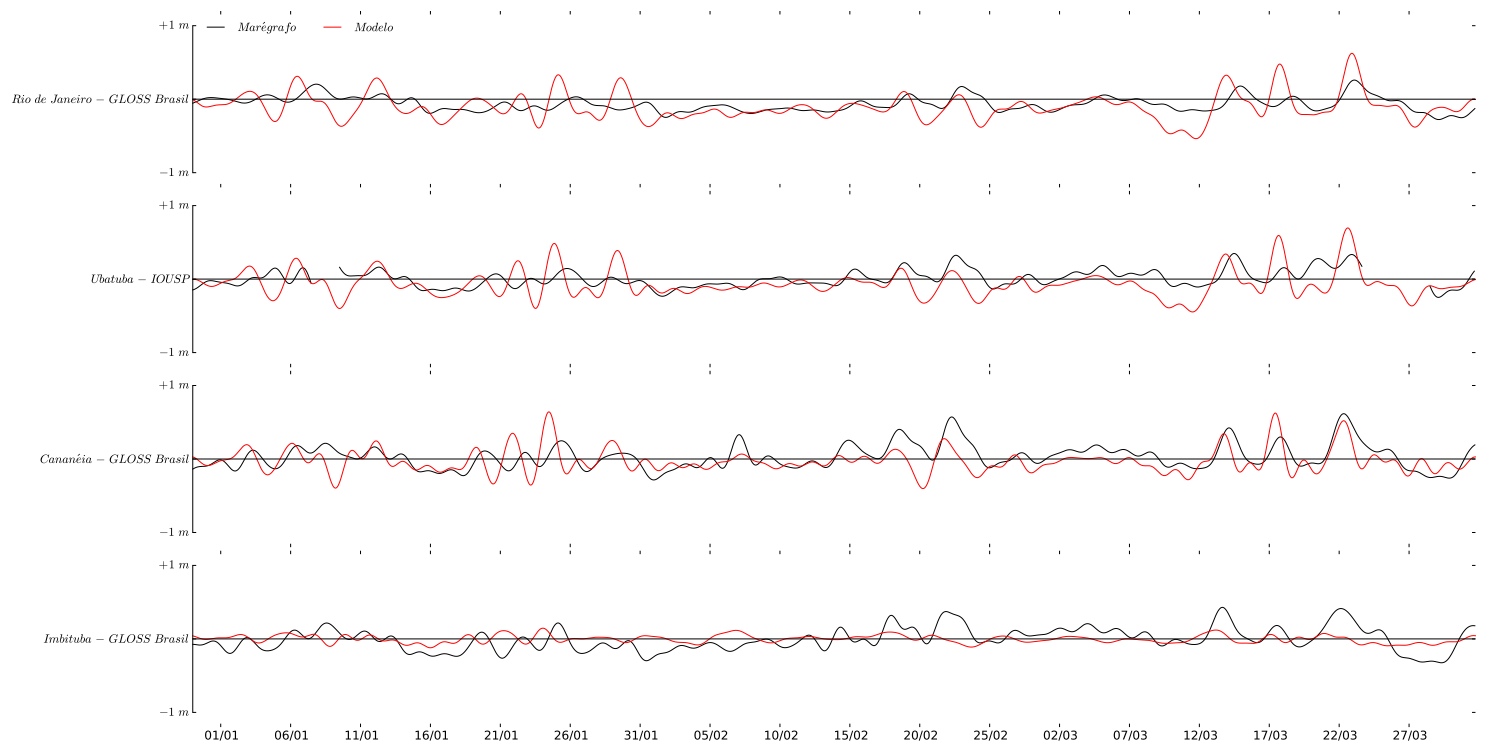

Figura 4.16: Séries de tempo de elevação subinercial da superfície livre do mar modelada (Experimento 1A - linha preta) e observada (linha vermelha) durante o verão de 2003. Os locais representativos de cada série estão listados na lateral esquerda de cada painel.

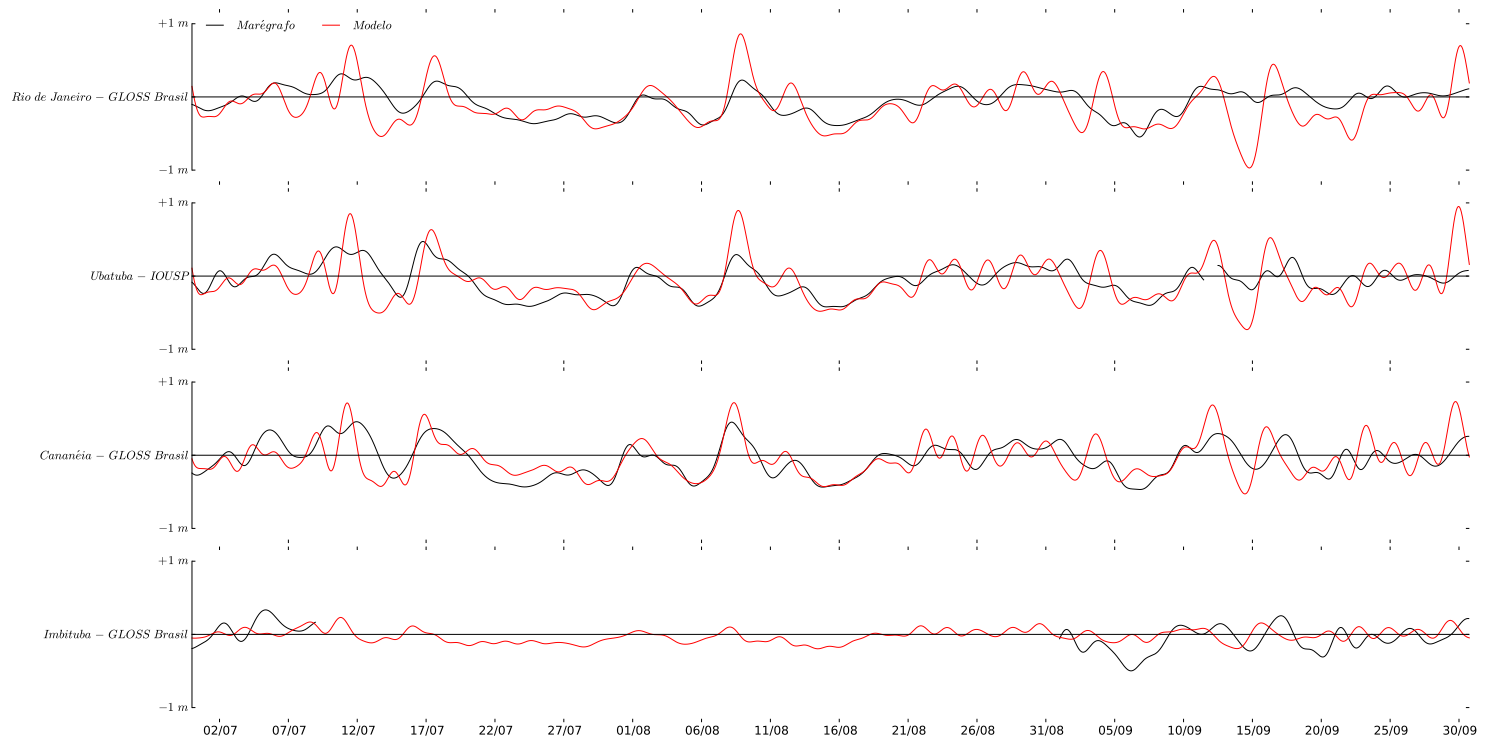

Figura 4.17: Séries de tempo de elevação subinercial da superfície livre do mar modelada (Experimento 1B - linha preta) e observada (linha vermelha) durante o inverno de 2004. Os locais representativos de cada série estão listados na lateral esquerda de cada painel. 
Tabela 4.4: Estimativas estatísticas dos dados de elevação da superfície livre do mar coletados em marégrafos (coletado) e do banco de dados oceânico (modelo).

\begin{tabular}{|c|c|c|c|c|}
\hline & \multicolumn{2}{|c|}{ Verão } & \multicolumn{2}{|c|}{ Inverno } \\
\hline & Modelo & Coletado & Modelo & Coletado \\
\hline \multicolumn{5}{|c|}{ Rio de Janeiro - GLOSS Brasil } \\
\hline Média (m) & $-0,10$ & $-0,07$ & $-0,11$ & $-0,07$ \\
\hline Mínimo (m) & $-0,99$ & $-0,89$ & $-1,53$ & $-1,02$ \\
\hline Máximo (m) & 1,11 & 0,77 & 1,22 & 0,78 \\
\hline Amplitude (m) & 2,10 & 1,66 & 2,75 & 1,80 \\
\hline Variância $\left(\mathrm{m}^{2}\right)$ & 0,11 & 0,09 & 0,16 & 0,12 \\
\hline Variância $\left(\mathrm{m}^{2}\right)$ - subinercial & 0,03 & 0,01 & 0,08 & 0,03 \\
\hline Porcentagem subinercial & 29,0 & 10,6 & 49,6 & 26,8 \\
\hline \multicolumn{5}{|c|}{ Ubatuba - IOUSP } \\
\hline Média (m) & $-0,06$ & 0,00 & $-0,07$ & $-0,06$ \\
\hline Mínimo (m) & $-0,96$ & $-0,92$ & $-1,36$ & $-1,10$ \\
\hline Máximo (m) & 1,17 & 0,80 & 1,56 & 2,61 \\
\hline Amplitude (m) & 2,13 & 1,73 & 2,92 & 3,71 \\
\hline Variância $\left(\mathrm{m}^{2}\right)$ & 0,11 & 0,09 & 0,16 & 0,13 \\
\hline Variância $\left(\mathrm{m}^{2}\right)$ - subinercial & 0,03 & 0,01 & 0,08 & 0,04 \\
\hline Porcentagem subinercial & 30,0 & 14,7 & 50,5 & 32,4 \\
\hline \multicolumn{5}{|c|}{ Cananéia - GLOSS Brasil } \\
\hline Média (m) & $-0,03$ & 0,03 & $-0,05$ & $-0,05$ \\
\hline Mínimo (m) & $-1,45$ & $-1,12$ & $-1,22$ & $-1,23$ \\
\hline Máximo (m) & 1,59 & 1,16 & 1,49 & 0,99 \\
\hline Amplitude (m) & 3,04 & 2,27 & 2,71 & 2,22 \\
\hline Variância $\left(\mathrm{m}^{2}\right)$ & 0,15 & 0,15 & 0,18 & 0,18 \\
\hline Variância $\left(\mathrm{m}^{2}\right)$ - subinercial & 0,03 & 0,03 & 0,06 & 0,05 \\
\hline Porcentagem subinercial & 17,2 & 17,6 & 34,7 & 28,5 \\
\hline \multicolumn{5}{|c|}{ Imbituba - GLOSS Brasil } \\
\hline Média (m) & 0,00 & $-0,01$ & $-0,02$ & $-0,04$ \\
\hline Mínimo (m) & $-0,52$ & $-0,74$ & $-0,61$ & $-0,69$ \\
\hline Máximo (m) & 0,43 & 0,69 & 0,47 & 0,65 \\
\hline Amplitude (m) & 0,95 & 1,43 & 1,09 & 1,34 \\
\hline Variância $\left(\mathrm{m}^{2}\right)$ & 0,03 & 0,05 & 0,03 & 0,07 \\
\hline Variância $\left(\mathrm{m}^{2}\right)$ - subinercial & 0,00 & 0,02 & 0,01 & 0,03 \\
\hline Porcentagem subinercial & 9,1 & 44,7 & 21,1 & 44,4 \\
\hline
\end{tabular}


A Tabela 4.5 quantifica, em termos de correlação, skill e NRMS, as diferenças entre as séries modeladas (Experimentos 1A e 1B) e medidas, em período de verão e inverno, tanto para as séries totais quanto as subinerciais. Para as séries totais, o skill tem valores superiores a 0,81 em todas os locais, tanto em período de verão quanto de inverno. O maior valor $(0,91)$ foi obtido no verão no Rio de Janeiro GLOSS Brasil, e o menor $(0,79)$ em Imbituba - GLOSS Brasil. Para estas séries totais, as correlações entre as séries modeladas e observadas variaram desde 0,69 em Imbituba - GLOSS Brasil e Cananéia - GLOSS Brasil a 0,85 no Rio de Janeiro GLOSS Brasil, ambos no verão. No inverno o maior valor $(0,79)$ foi obtido no Rio de Janeiro - GLOSS Brasil. Para o NRMS, os menores erros (9\%) foram obtidos no Rio de Janeiro - GLOSS Brasil (ambas as estações) e em Ubatuba - IOUSP (inverno). Os maiores erros (18\%) foram obtidos em Imbituba - GLOSS Brasil tanto no verão quanto de inverno. Para a porção subinercial do espectro das séries medidas e modeladas, o skill mínimo ocorreu na estação de Imbituba - GLOSS Brasil (0,36), em períodos de verão, e o máximo $(0,77)$ em Cananéia - GLOSS Brasil no inverno. Baixas correlações foram obtidas em Imbituba - GLOSS Brasil (0,14 no verão e 0,17 no inverno). As maiores correlações no verão $(0,62)$ e no inverno $(0,60)$ estiveram no Rio de Janeiro - GLOSS Brasil. Para o NRMS os maiores erros estiveram em Imbituba - GLOSS Brasil, com $58 \%$ no verão e $46 \%$ no inverno.

Tabela 4.5: Correlação mínima com $95 \%$ de confiabilidade, skill e NRMS entre as séries coletadas por marégrafos e as modeladas nos Experimentos 1A (verão) e 1B (Inverno). Sub. significa subinercial.

\begin{tabular}{l|cc|cc|cc}
\hline & \multicolumn{2}{c}{ Skill } & \multicolumn{2}{c}{ Correlação } & \multicolumn{2}{c}{ NRMS } \\
\hline & Total & Sub. & Total & Sub. & Total & Sub. \\
\hline \multicolumn{7}{c}{ Verão } \\
\hline Imbituba - GLOSS BRASIL & 0,81 & 0,36 & 0,69 & 0,14 & 0,18 & 0,58 \\
Cananéia - GLOSS BRASIL & 0,83 & 0,64 & 0,69 & 0,38 & 0,10 & 0,18 \\
Ubatuba - IOUSP & 0,88 & 0,57 & 0,78 & 0,33 & 0,10 & 0,16 \\
Rio de Janeiro - GLOSS BRASIL & 0,91 & 0,56 & 0,85 & 0,56 & 0,09 & 0,15 \\
\hline \multicolumn{7}{l}{ Inverno } \\
\hline Imbituba - GLOSS BRASIL & 0,79 & 0,40 & 0,67 & 0,17 & 0,18 & 0,46 \\
Cananéia - GLOSS BRASIL & 0,86 & 0,77 & 0,75 & 0,62 & 0,11 & 0,17 \\
Ubatuba - IOUSP & 0,86 & 0,73 & 0,76 & 0,60 & 0,09 & 0,14 \\
Rio de Janeiro - GLOSS BRASIL & 0,87 & 0,68 & 0,79 & 0,58 & 0,09 & 0,14 \\
\hline
\end{tabular}




\subsection{Estudo dos padrões atmosféricos sobre a Plata- forma Continental Sudeste}

\subsubsection{Campos médios}

O padrão médio de ventos para o verão e o inverno (Figura 4.18) mostra que a porção norte da PCSE está submetida a ventos de nordeste e regiões ao sul de leste. Na porção norte a intensidade média é de cerca de $5 \mathrm{~m} . \mathrm{s}^{1}$, enquanto que nas porções central e sul estes valores ficam próximos a $2 \mathrm{~m} . \mathrm{s}^{1}$. Os ventos médios no inverno são predominantemente de leste em toda a PCSE, com intensidades inferiores às obtidas no verão.

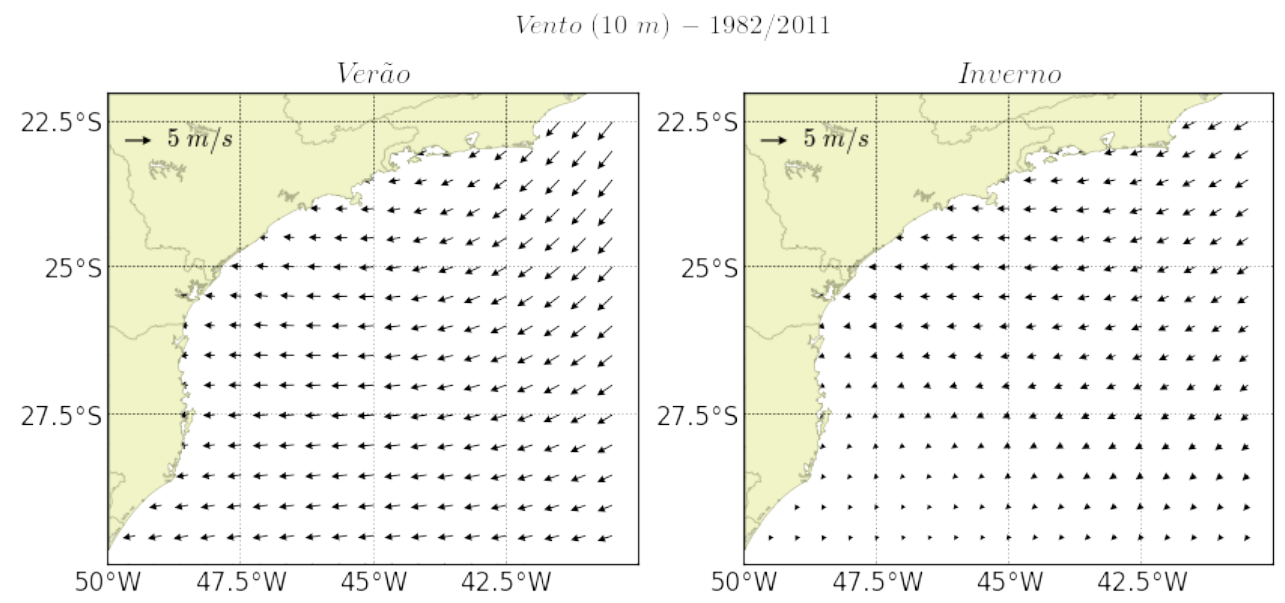

Figura 4.18: Vento médio (nível $10 \mathrm{~m}$ ) para o verão (painel da esquerda) e para o inverno (painel da direita).

A variância da componente zonal do vento no verão (Figura 4.19, painel da esquerda) é de aproximadamente $10 \mathrm{~m}^{2} . \mathrm{s}^{-2}$ em toda a PCSE, com menores valores na região costeira e maiores ao largo. No inverno, (Figura 4.19, painel da direita), os menores valores também ocorrem na região costeira; contudo, na porção mais externa e na região sul da PCSE os valores chegam a $30 \mathrm{~m}^{2} . \mathrm{s}^{-2}$, denotando maior variabilidade desta componente no inverno.

Para a componente meridional do vento, o inverno (Figura 4.20, painel da direita) também apresenta maior variância média do que o verão (Figura 4.20, painel da esquerda). Nas duas épocas os menores valores estão próximos à costa e os maiores ao largo. No verão, os valores variam entre $10 \mathrm{~m}^{2} \cdot \mathrm{s}^{-2}$ e $30 \mathrm{~m}^{2} \cdot \mathrm{s}^{-2}$, e no inverno entre 
$15 \mathrm{~m}^{2} \cdot \mathrm{s}^{-2}$ e $40 \mathrm{~m}^{2} \cdot \mathrm{s}^{-2}$.

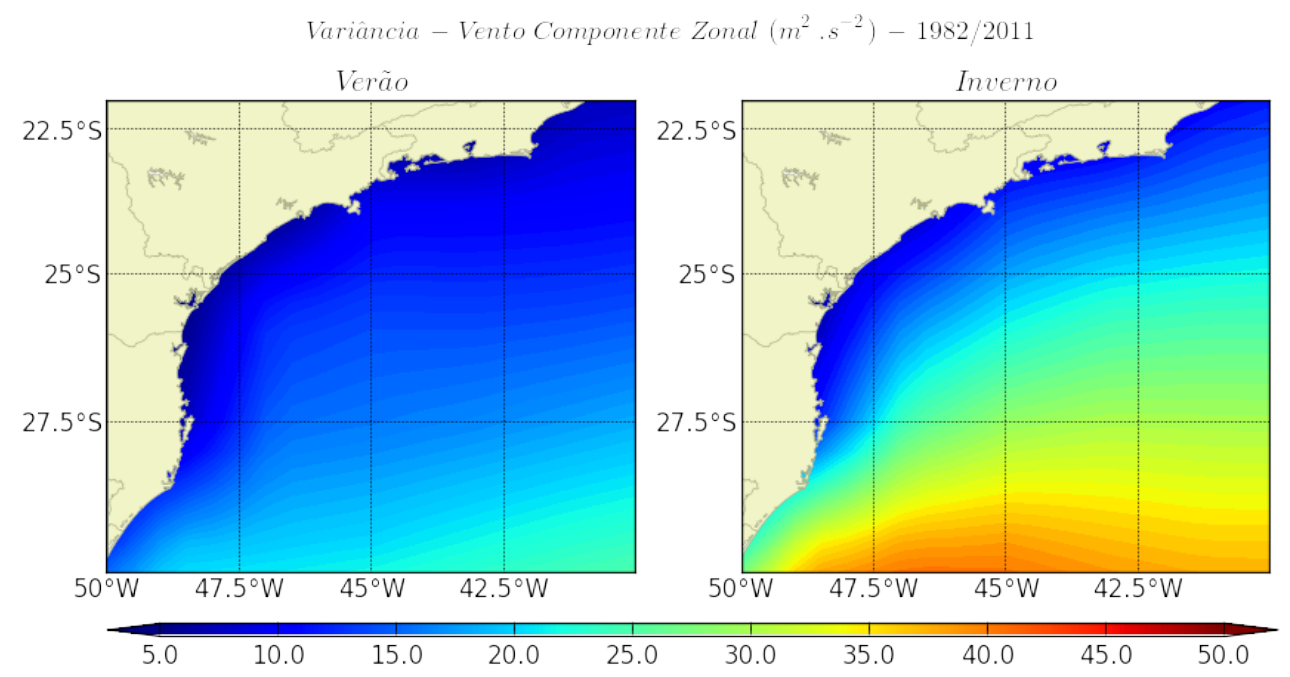

Figura 4.19: Variância média (cores em $\mathrm{m}^{2} . \mathrm{s}^{-2}$ ) da componente zonal do vento para o verão (painel da esquerda) e para o inverno (painel da direita).

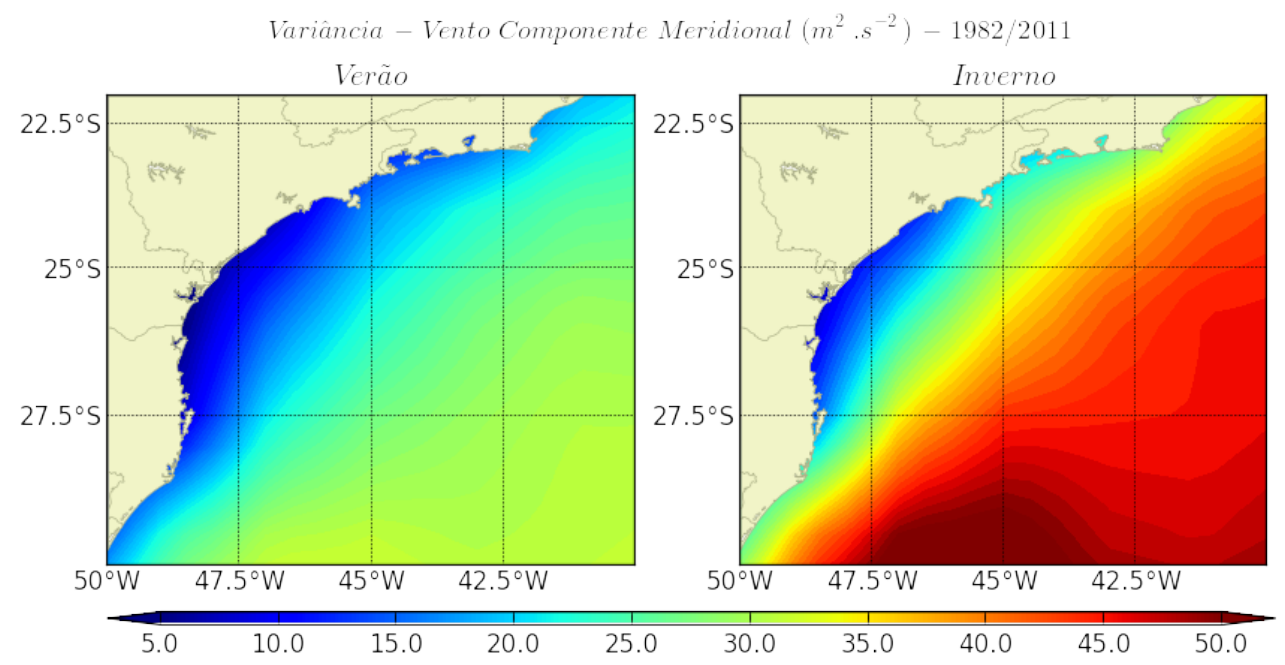

Figura 4.20: Variância média (cores em $\mathrm{m}^{2} . \mathrm{s}^{-2}$ ) da componente meridional do vento o verão (painel da esquerda) e para o inverno (painel da direita). 
A temperatura média atmosférica no verão (painel da esquerda da Figura 4.21) indica que a porção norte da PCSE é mais quente (cerca de $23,0^{\circ} \mathrm{C}$ ) do que a porção sul (cerca de $22,5^{\circ} \mathrm{C}$ ). Ainda, pode-se observar que nas proximidades da costa os valores médios são inferiores àqueles estimados ao largo. Para os meses de inverno (painel da direita da Figura 4.21) a relação entre maiores e menores valores na porção norte e sul, costeira e ao largo, são mantidas, contudo, com temperaturas inferiores. Nesta época do ano a porção norte tem temperatura média de $21,0^{\circ} \mathrm{Ce}$ a porção sul $17^{\circ} \mathrm{C}$.

Os campos de variância da temperatura superficial (Figura 4.22) mostram que os maiores valores estão próximos à costa e os menores ao largo. No verão, os maiores valores estão centrados na porção sul costeira da PCSE, com $8\left({ }^{\circ} \mathrm{C}\right)^{2}$; nas demais regiões os valores são próximos à $0\left({ }^{\circ} \mathrm{C}\right)^{2}$, denotando baixa variabilidade. Para o inverno a região costeira também apresenta maiores valores de variância do que a região ao largo, com máximos de $18\left({ }^{\circ} \mathrm{C}\right)^{2}$ na porção centro-sul do litoral da PCSE. Estes valores mostram maior variabilidade, principalmente na região costeira da PCSE, em período de inverno.

Para os campos médios de pressão atmosférica (Figura 4.23), há diferenças consideráveis entre as médias de verão (painel da esquerda) e de inverno (painel da direita). Tanto no verão quanto no inverno, a pressão atmosférica média é praticamente homogênea em toda a PCSE. No verão, o valor médio é de $1013 \mathrm{hPa}$, enquanto que no inverno este valor é de $1019 \mathrm{hPa}$. A variância associada a este campo médio (Figura 4.24) mostra que na porção sul da PCSE ocorre maior variabilidade que na porção norte. No verão (inverno) a variância da pressão atmosférica na porção sul da PCSE é de $15,0 \mathrm{hPa}^{2}\left(27,5 \mathrm{hPa}^{2}\right)$, enquanto que na porção norte é de $7,0 \mathrm{hPa}^{2}$ $\left(18,0 \mathrm{hPa}^{2}\right)$. Estes valores mostram que no inverno, em toda a PCSE ocorre maior variabilidade deste parâmetro e, em ambas estações do ano, a porção sul sofre mais variações que a porção norte da PCSE. 


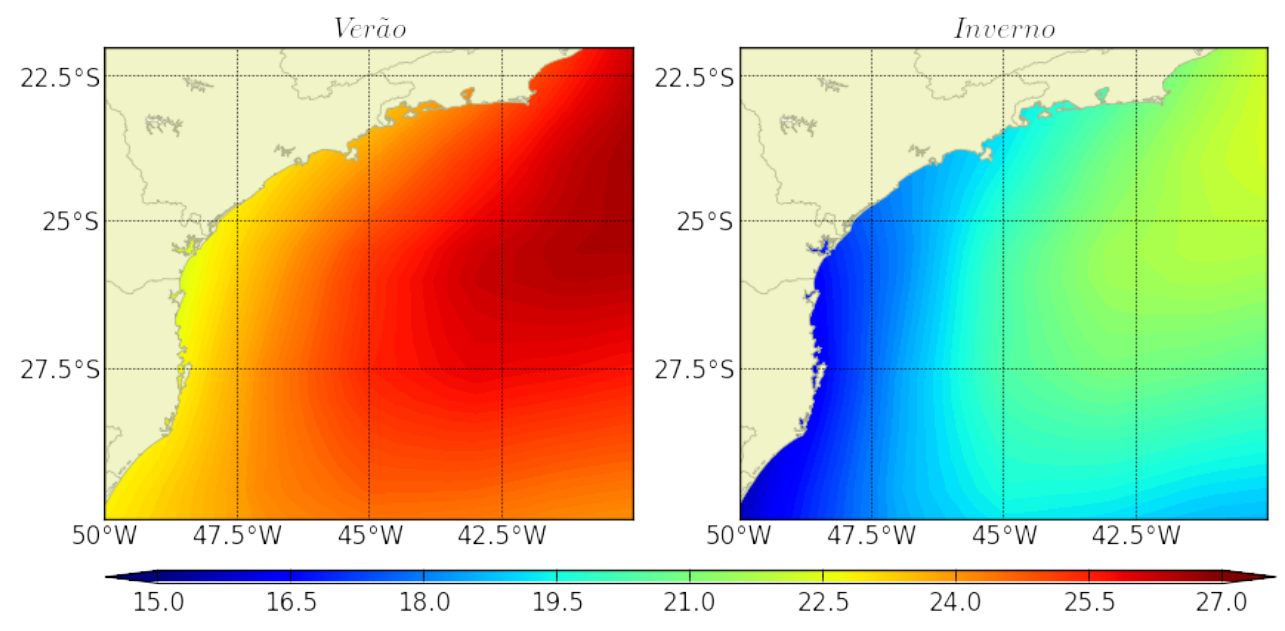

Figura 4.21: Temperatura atmosférica média em ${ }^{\circ} \mathrm{Cno}$ nível de $0 \mathrm{~m}$, para o verão (painel da esquerda) e para o inverno (painel da direita).

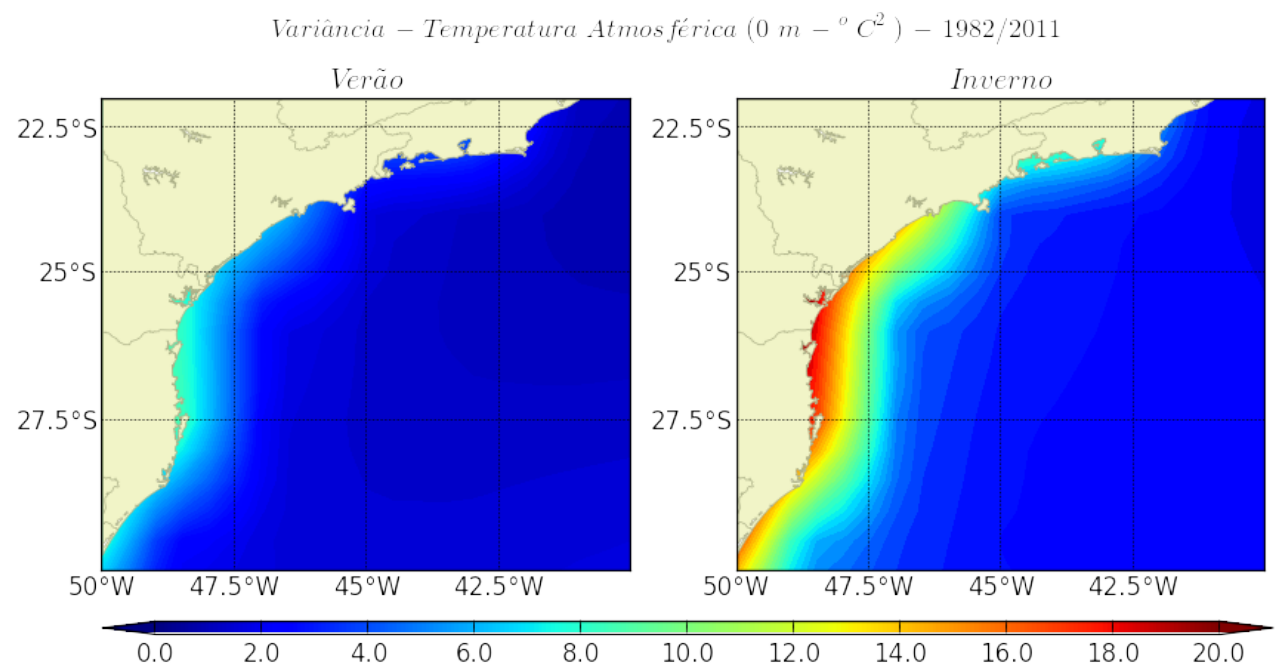

Figura 4.22: Variância (cores em $\left({ }^{\circ} \mathrm{C}\right)^{2}$ ) da temperatura atmosférica no nível $0 \mathrm{~m}$ para o verão (painel da esquerda) e para o inverno (painel da direita). 
Pressão Atmos férica $(0 m-h P a)-1982 / 2011$

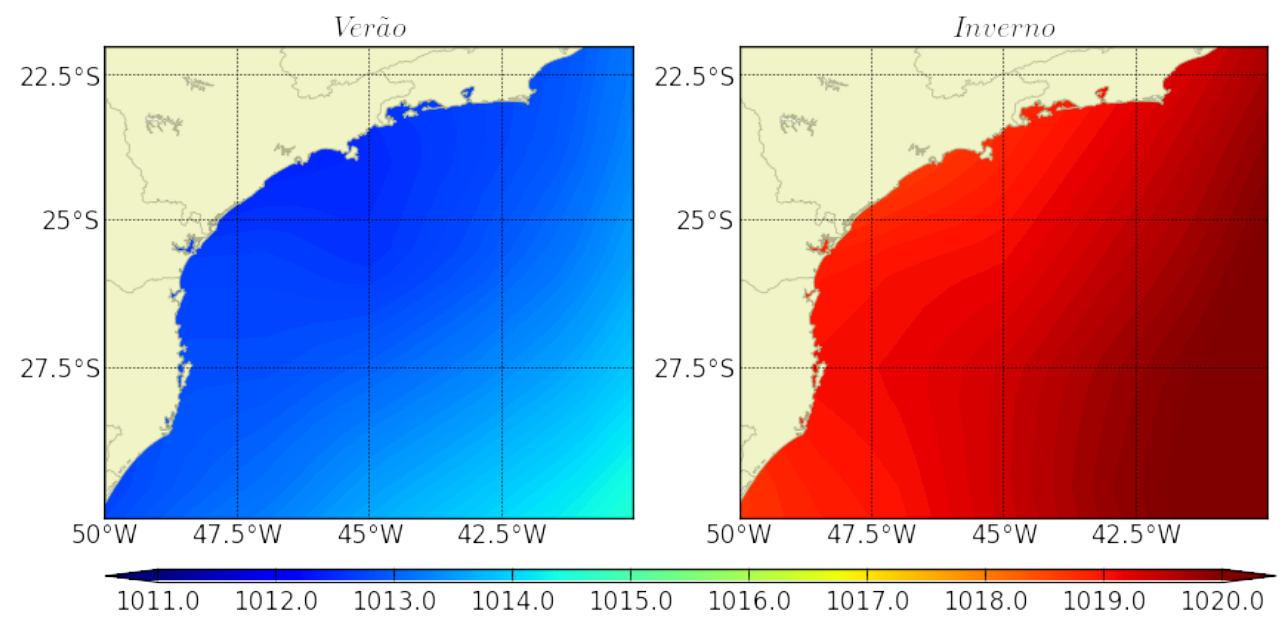

Figura 4.23: Pressão atmosférica média (cores em $\mathrm{hPa}$ ) para o verão (painel da esquerda) e para o inverno (painel da direita).

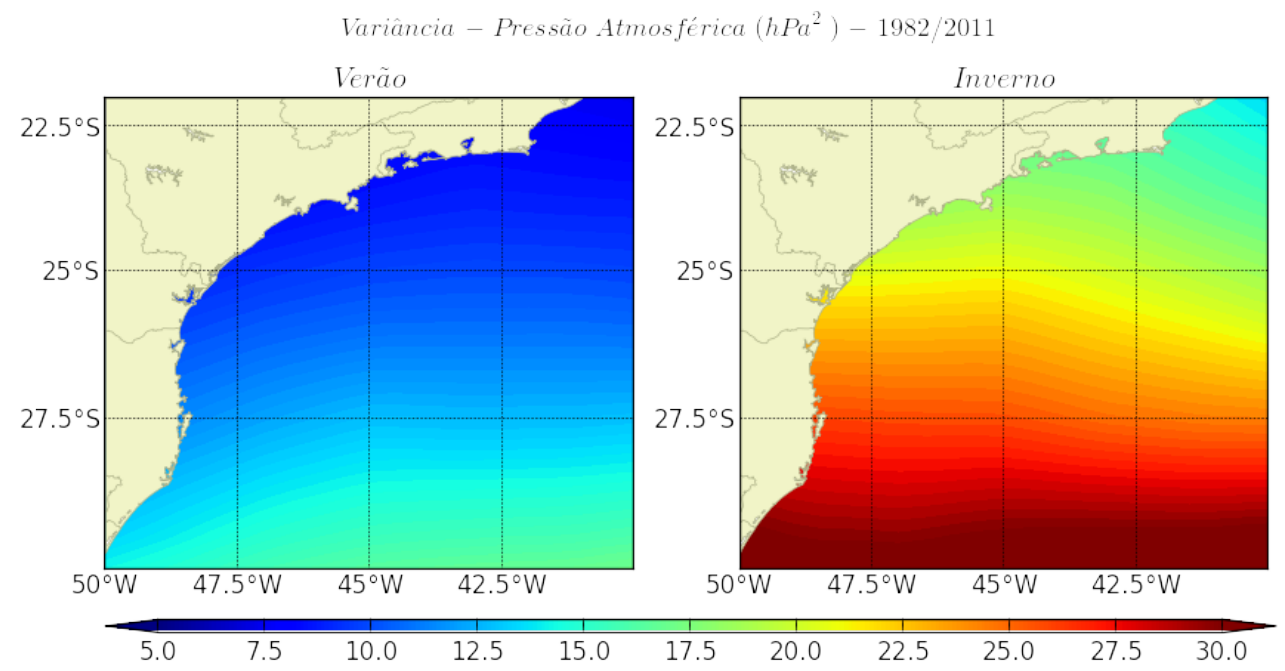

Figura 4.24: Variância da pressão atmosférica (cores em $\mathrm{hPa}^{2}$ ) para o verão (painel da esquerda) e para o inverno (painel da direita). 


\subsubsection{Perturbações sinóticas}

Analisando agora os resultados para as FF que passam pela PCSE, as Tabelas 4.6 e 4.7 mostram a quantidade de FF observadas nos pontos SUL (S) e NORTE (N) da PCSE (conforme Figura 3.3) e as que não percorreram toda a extensão da PCSE (D), nos meses de verão e inverno, respectivamente. Os resultados mostram que a quantidade média de FF que passam pelo ponto SUL não varia significativamente entre o verão e o inverno, com menor valor médio no mês de fevereiro $(3,0 \pm 1,1$ $\mathrm{FF})$ e maior no mês de março $(3,8 \pm 0,8 \mathrm{FF})$. Já para o ponto NORTE, a diferença entre a passagem de FF nos meses de verão e inverno é maior, sendo julho $(3,1 \pm 1,1$ $\mathrm{FF})$ e setembro $(3,1 \pm 0,9 \mathrm{FF})$ os meses com maiores média. Esta diferença entre os pontos SUL e NORTE reflete nas quantidades de FF que não percorreram toda a extensão da PCSE (D nas Tabelas 4.6 e 4.7) tanto no verão quanto no inverno. Em meses de verão o número médio de FF que não percorreram toda a extensão da PCSE é superior ao observado nos meses de inverno. A maior quantidade média de FF que não percorreram toda a extensão da PCSE foi observada no mês de janeiro $(2,5 \pm 0,7 \mathrm{FF})$ e ao menor em setembro $(0,4 \pm 0,5 \mathrm{FF})$. O valor somado de todas as FF que não percorreram toda a extensão da PCSE no verão obtido neste estudo é de $189 \mathrm{FF}$ e no inverno $55 \mathrm{FF}$.

Tabela 4.6: Estimativa estatísticas das FF identificadas em período de verão nos pontos SUL (S), NORTE (N) e aquelas que não percorreram toda a extensão da PCSE (D).

\begin{tabular}{|l|c|c|c|c|c|c|c|c|c|}
\cline { 2 - 10 } \multicolumn{1}{c|}{} & \multicolumn{9}{c|}{ Verão (1982-2011) } \\
\cline { 2 - 10 } \multicolumn{1}{c|}{} & \multicolumn{3}{c|}{ Janeiro } & \multicolumn{3}{c|}{ Fevereiro } & \multicolumn{3}{c|}{ Março } \\
\cline { 2 - 10 } & $\mathrm{S}$ & $\mathrm{N}$ & $\mathrm{D}$ & $\mathrm{S}$ & $\mathrm{N}$ & $\mathrm{D}$ & $\mathrm{S}$ & $\mathrm{N}$ & $\mathrm{D}$ \\
\hline Total & 106 & 30 & 76 & 90 & 28 & 62 & 113 & 62 & 51 \\
Média anual & 3,5 & 1,0 & 2,5 & 3,0 & 0,9 & 2,0 & 3,8 & 2,1 & 1,7 \\
Desvio padrão & 1,0 & 0,9 & 0,7 & 1,1 & 0,9 & 0,8 & 0,8 & 1,0 & 0,6 \\
\hline
\end{tabular}

Tabela 4.7: Estimativa estatísticas das FF identificadas em período de inverno nos pontos SUL (S), NORTE (N) e aquelas que não percorreram toda a extensão da PCSE (D).

\begin{tabular}{|l|c|c|c|c|c|c|c|c|c|}
\cline { 2 - 10 } \multicolumn{1}{c|}{} & \multicolumn{9}{c|}{ Inverno (1982-2011) } \\
\cline { 2 - 10 } \multicolumn{1}{c|}{} & \multicolumn{3}{c|}{ Julho } & \multicolumn{3}{c|}{ Agosto } & \multicolumn{3}{c|}{ Setembro } \\
\cline { 2 - 10 } & $\mathrm{S}$ & $\mathrm{N}$ & $\mathrm{D}$ & $\mathrm{S}$ & $\mathrm{N}$ & $\mathrm{D}$ & $\mathrm{S}$ & $\mathrm{N}$ & $\mathrm{D}$ \\
\hline Total & 108 & 92 & 16 & 108 & 81 & 27 & 105 & 93 & 12 \\
Média anual & 3,6 & 3,1 & 0,5 & 3,6 & 2,7 & 0,9 & 3,5 & 3,1 & 0,4 \\
Desvio padrão & 1,0 & 1,1 & 0,5 & 0,9 & 1,1 & 0,5 & 0,8 & 0,9 & 0,5 \\
\hline
\end{tabular}


A partir da identificação de todas as FF que passaram pela PCSE, foi possível obter as FF médias de verão, de inverno, tanto aquelas que passaram por toda a PCSE quanto aquelas que não percorreram toda esta extensão. A FF média de verão (Figura 4.25) é apresentada num intervalo de tempo de $192 \mathrm{~h}$, sendo que esta passa pelo Cabo de Santa Marta no instante 48h (nas primeiras 48 h são consideradas as características médias atmosféricas apresentadas nas Figuras 4.18, 4.23 e 4.21. Neste intervalo de tempo, os ventos na PCSE, inicialmente de nordeste, mudam de direção para sudoeste, sofrendo intensificação, em toda a extensão da PCSE em aproximadamente $24 \mathrm{~h}$. Os ventos voltam a ter origem nordeste no instante de tempo aproximado de $160 \mathrm{~h}$. A pressão atmosférica inicialmente sofre decréscimo em toda a PCSE e, no momento de virada do vento, apresenta aumento; o mínimo é registrado no instante de virada do vento. A diferença entre o máximo e o mínimo de pressão é de aproximadamente $5 \mathrm{hPa}$. A temperatura atmosférica apresenta decréscimo com a virada do vento, reduzindo cerca de $2,0{ }^{\circ} \mathrm{Cn}$ a porção sul da PCSE e 1,0 ${ }^{\circ} \mathrm{Cna}$ porção norte (PRJ).

Para a FF média de verão que não percorre toda a extensão da PCSE (Figura 4.26), na região sul (PSC) e central (PSP) da PCSE as propriedades atmosféricas são alteradas de forma semelhante à descrita para a FF que percorre toda a extensão da PCSE. A diferença ocorre na porção norte (PRJ), onde o vento de origem nordeste sofre desintensificação, a pressão atmosférica tem pouco decréscimo e não são observadas variações negativas significativas da temperatura.

Em situação de inverno, tanto a FF média (Figura 4.27) quanto àquela que não percorre toda a extensão da PCSE (Figura 4.28) apresentam características semelhantes às descritas para o período de verão (Figuras 4.25 e 4.26, respectivamente). Para a FF média, nos três pontos de observação, os ventos apresentam variação da direção de nordeste para sudeste e, finalmente, retornando a nordeste. As pressões têm queda no instante de inversão do vento e posterior aumento juntamente com o vento de sul, e as temperaturas decrescem de acordo com o aumento da intensidade do vento de sul. Comparativamente ao período de verão, no inverno a intensidade dos ventos de sul é superior, a variação da pressão atmosférica é próxima a $7 \mathrm{hPa}$ e a queda da temperatura na porção sul (norte) da PCSE é de aproximadamente $4^{\circ} \mathrm{C}\left(2,5^{\circ} \mathrm{C}\right)$. Para a FF média de inverno que não percorre toda a PCSE (Figura 4.28) diferentemente do observado em período de verão, o vento no ponto PRJ (porção norte da PCSE) sofre alteração, tendo sua origem alterada de nordeste para leste (não chegando a girar de sul) nos momentos posteriores às alteração dos ventos nos pontos ao sul (PSC e PSP). Contudo, neste ponto ao norte (PRJ), como na estação de verão, não ocorre alteração significativa na temperatura superficial atmosférica. 
$68-142$
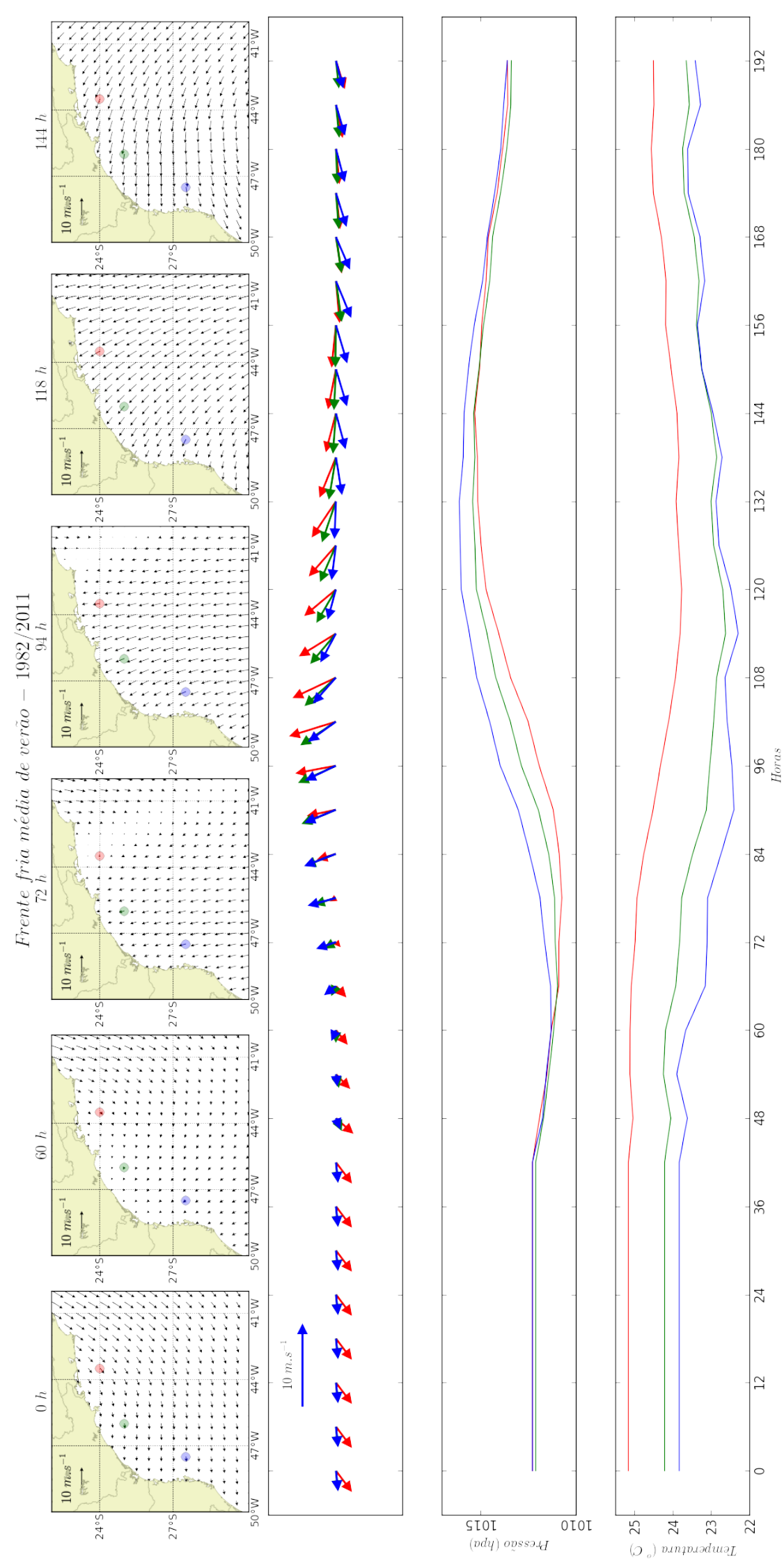

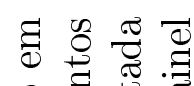

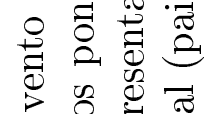

究

苋造

总完

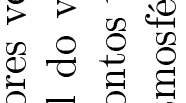

声需总

की

过

:

击

苗.

\%

됴

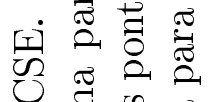

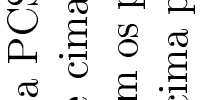

ช

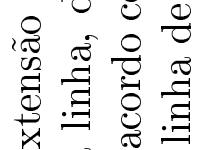

\%

㱐递

.

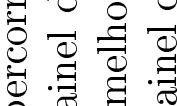

㫋

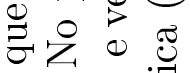

的金苞

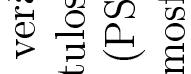

ช

范苛

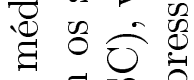

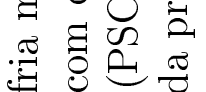

$\exists$ 둥

总䓵卷

ํํ के के

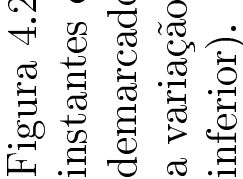



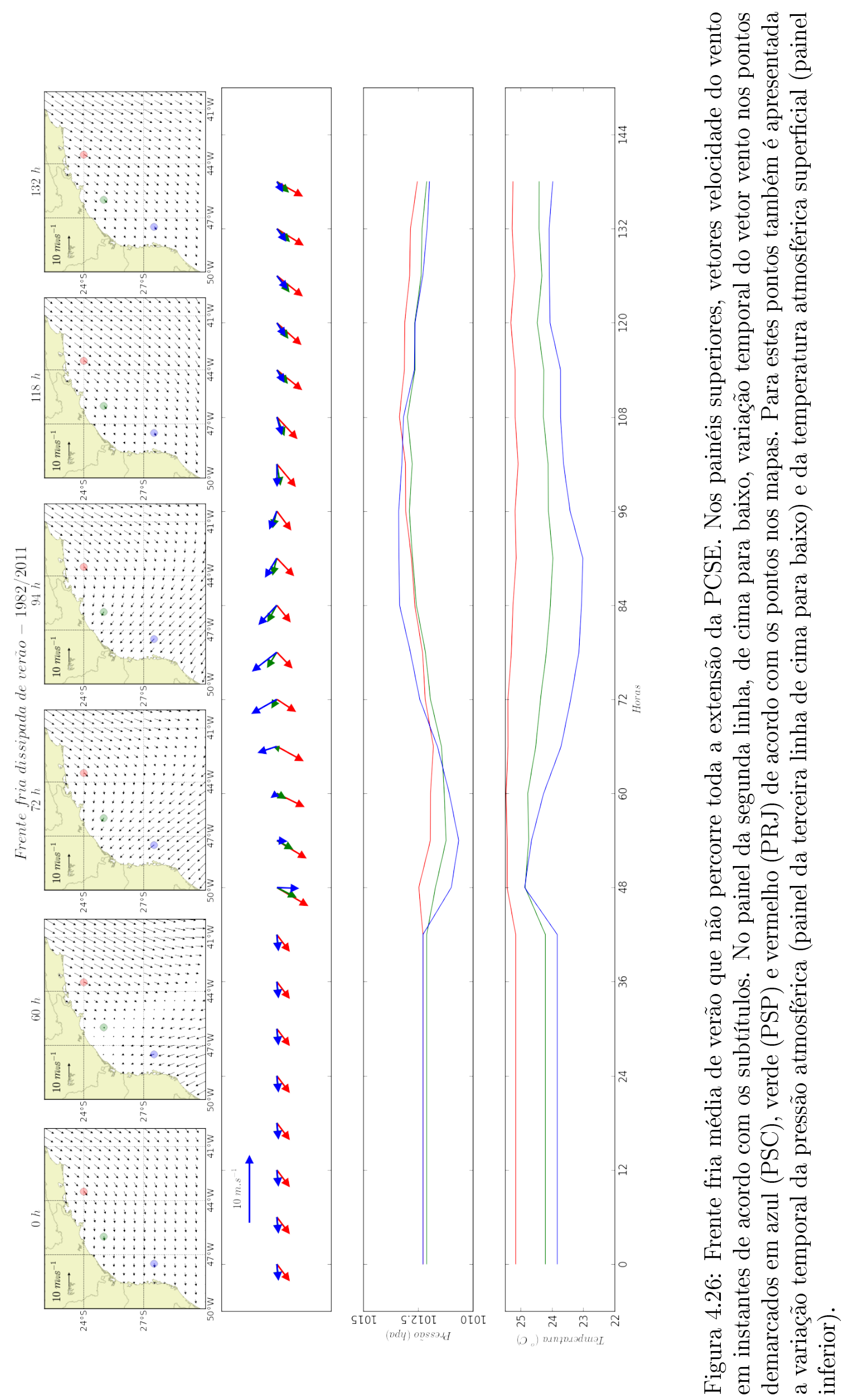


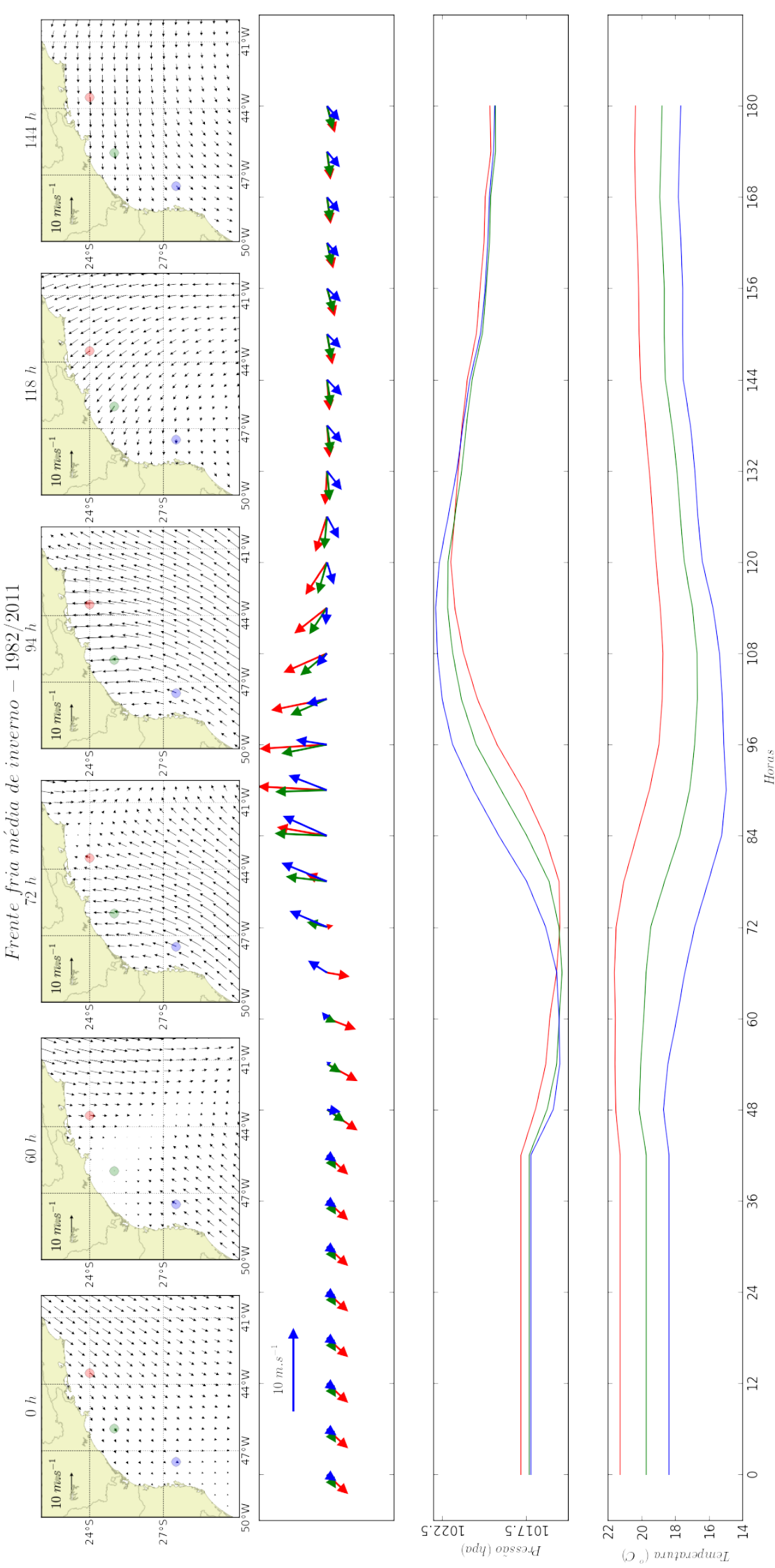

욜요

$\begin{array}{llll}1 & 0 & 0 \\ 0 & 0 & 0 \\ 0 & 0 & 0 \\ 0 & 0 & 0 & 0 \\ 0 & 0 & 0\end{array}$

类 00.

氜

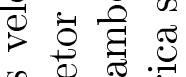

य

$\begin{array}{lll}0 & 0 \\ 0 & 0 & 0 \\ 0 & 0 & 0 \\ 0 & 0\end{array}$

के एँ

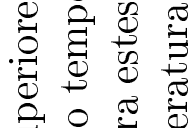

क्ष

蛇

.

告.

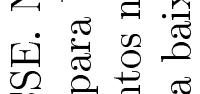

记

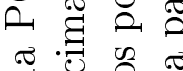

ซ

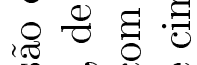

ปี ฮี

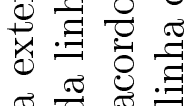

๘

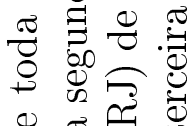

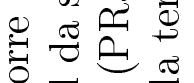

웡.

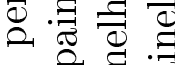

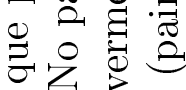

نे 0.

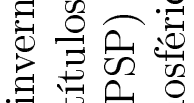

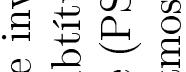

ข

:

घ

急记

苞苛

语

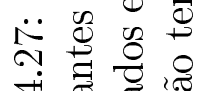

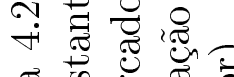

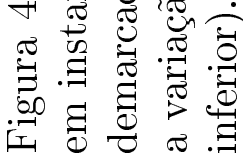



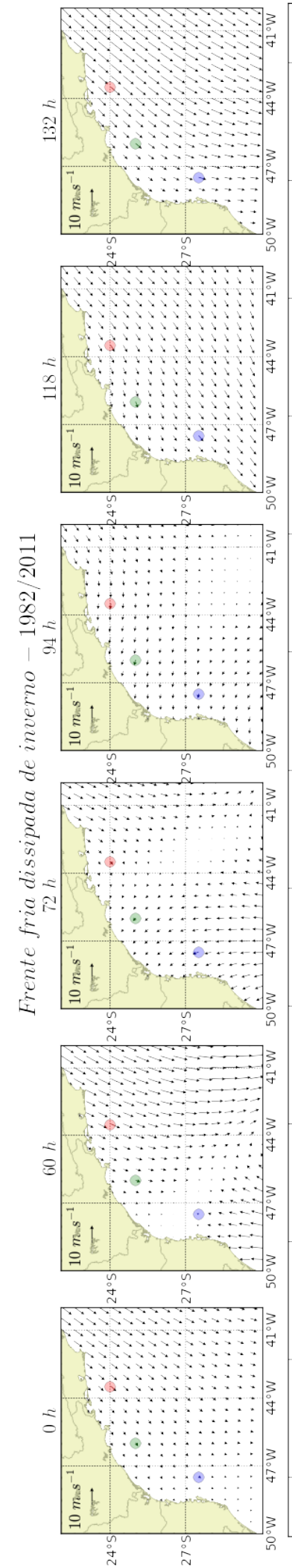

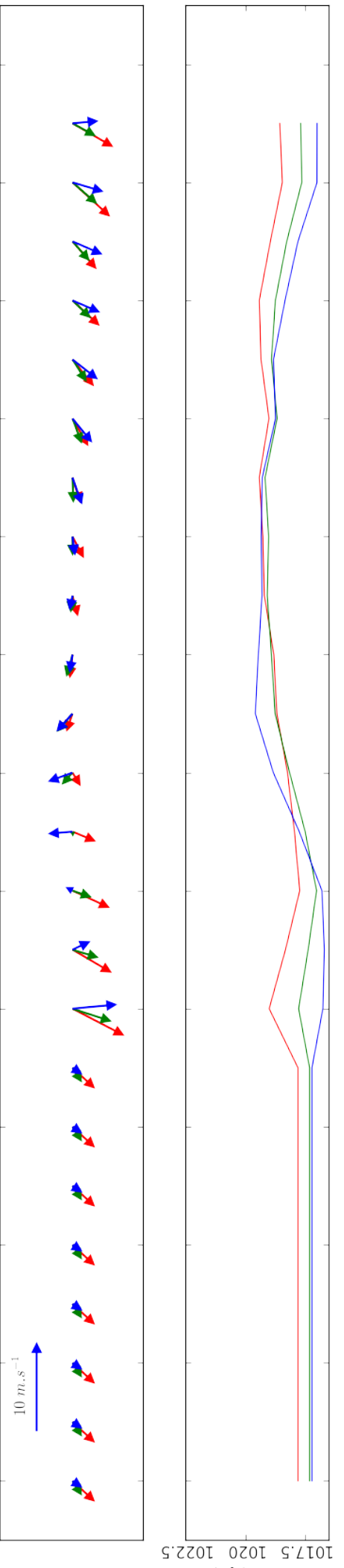

(vdy) ovssadd

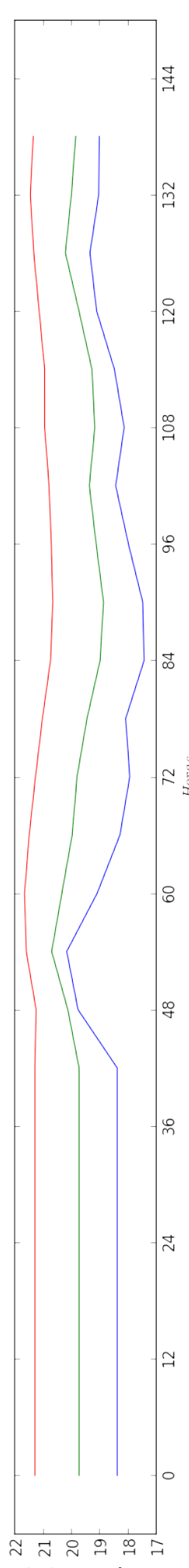

충ำ의

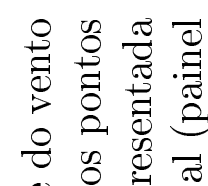

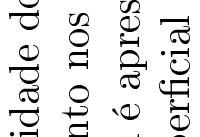

范

एं है हो

ये

宽

का

की

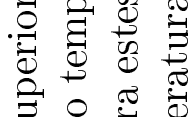

要若

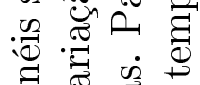

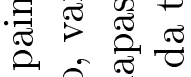

की 0 .

구웡

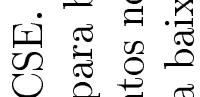

记芯泀

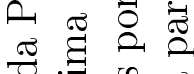

त) है क

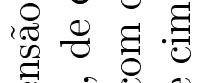

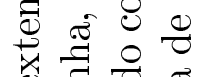

ब.

శี

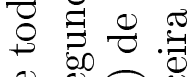

品

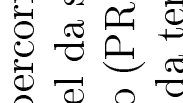

웜

饶

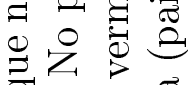

vن 0.0

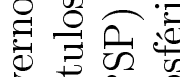

吾气急

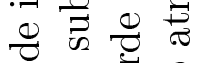

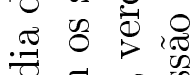

苞

율 융

苛范

卷

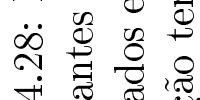

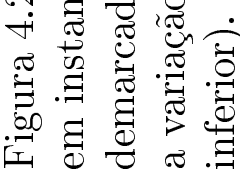




\subsection{Experimentos com ventos reais}

Nesta Seção estão apresentados os resultados referentes às simulações que tiveram como forçante os ventos e pressão atmosférica reais para os meses de verão de 2003 (Experimento 1A) e inverno de 2004 (Experimento 1B). Nesta Seção são analisadas as séries na banda subinercial do espectro. Inicialmente são dispostos os resultados atmosféricos (ventos e pressão atmosférica ) e posteriormente os resultados oceânicos (nível do mar).

Para o verão de 2003 (Figura 4.29), a inversão dos vetores velocidade de nordeste para sul-sudoeste indicam que em Cabo Frio ocorreu a passagem de 6 FF. Já em localidades mais ao sul, como Paranaguá, por exemplo, ocorreram 10 instantes de inversão da velocidade do vento. É possível notar que entre os dias 20/01/2003 e 15/03/2003 os ventos em Cabo Frio permaneceram praticamente sem rotação, diferentemente das localidades mais ao sul, que registraram inversões no vento, principalmente nas proximidades do dia 21/02/2003, desde Imbituba até Ubatuba. Já para o período de inverno de 2004 (Figura 4.30), as inversões de ventos foram semelhantes em todos os locais. Destaque somente para o período entre 21/09/2004 e 30/09/2004 quando, no Rio de Janeiro e em Cabo Frio, os ventos permaneceram praticamente sem mudança de direção, enquanto que nas estações mais ao sul há grande influência de ventos de leste. Neste período ocorreram aproximadamente 14 inversões do vento, de nordeste para sul/sudoeste. Ou seja, durante estes períodos de simulação os eventos de inversão dos ventos, típicos de passagens de FF sobre a PCSE, foram mais frequentes no inverno que no verão e, no verão, foram observados maior quantidade de eventos que alteraram o campo de ventos somente na porção sul-central da PCSE.

Avaliando-se os espectros de potência para a componente do vento perpendicular à costa (Figura 4.31) é possível notar que no verão, para a porção sul e norte da PCSE os períodos mais energéticos são aqueles superiores à 10 dias. Na região entre São Francisco e Peruíbe o período aproximado de 5 dias é o que apresenta a maior energia, contudo também inferior ao das outras localidades. No inverno períodos menores também apresentam máximos relativos de energia. O período entre 6-7 dias é bastante energético na porção da PCSE ao norte de Santos. Nesta região da PCSE períodos superiores à 15 dias também têm máximo relativos de energia. Para a porção central da PCSE o espectro é ruidoso, com máximos de energia relativa entre 5-8 dias e entre 10-30 dias. Para a porção sul da PCSE os períodos entre 5-12 dias e entre 17-40 dias são os mais energéticos. 


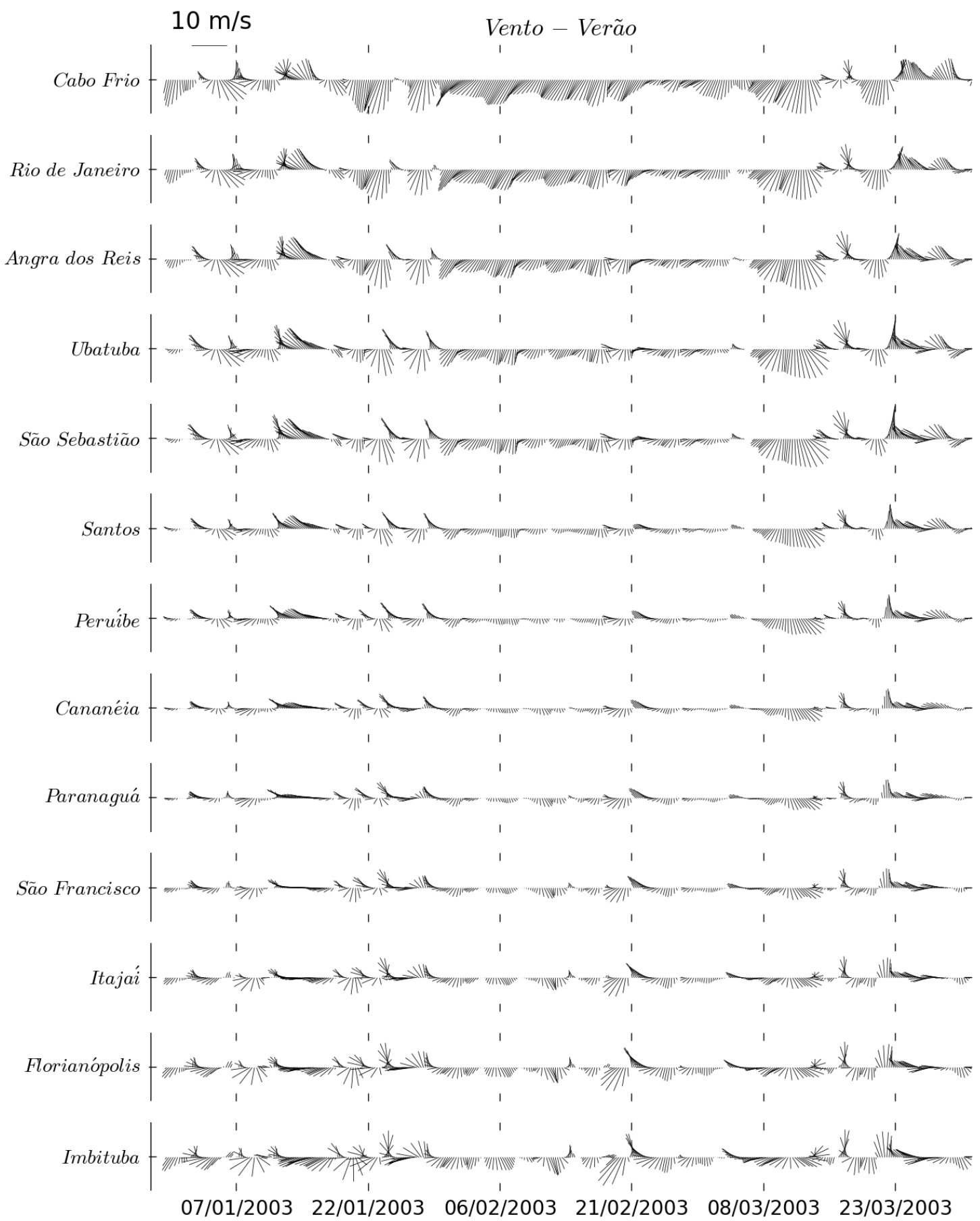

Figura 4.29: Vetores velocidade subinercial do vento para o verão de 2003, de acordo com os locais descritos à esquerda dos gráficos. O vetor de referência está localizado no canto superior esquerdo. O norte aponta para cima. 


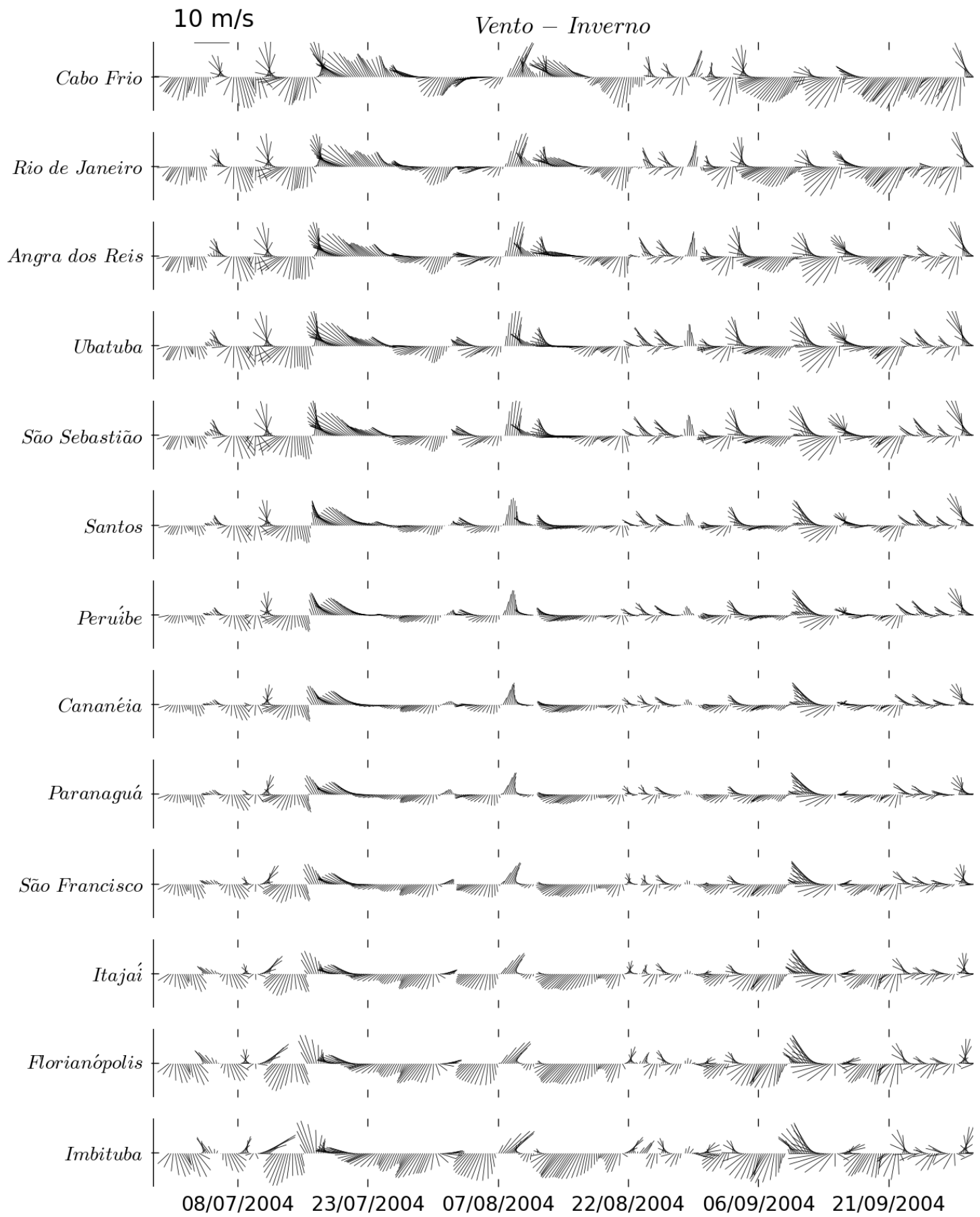

Figura 4.30: Vetores velocidade subinercial do vento para o inverno de 2004, de acordo com os locais descritos à esquerda dos gráficos. O vetor de referência está localizado no canto superior esquerdo. O norte aponta para cima. 
Para a componente do vento paralela à costa, o espectro de potência (Figura 4.32 mostra as maiores energias em períodos superiores a 3 dias, em toda a PCSE no verão e inverno. No verão, ao sul de Ilha Grande, períodos acima de 10 dias têm máximos relativos de energia e os períodos entre 4-6 dias em toda a PCSE. No inverno a faixa do espectro que tem máximo relativo de energia em toda a PCSE está centrada entre os períodos de 5-7 dias e, ao sul de São Francisco, os períodos mais energéticos estão entre 10-20 dias e, ao norte de Santos, os períodos mais energéticos são os superiores à 5 dias. Entre São Sebastião e Ilha Grande os períodos com máximos relativos de energia no inverno são os entre 6-7 dias e 20-40 dias.

Comparando os espectros das componentes do vento perpendicular e paralela à costa, no verão os períodos entre 5-8 dias, que são energéticos nos espectros de pressão atmosférica em toda a PCSE, também são energéticos na componente paralela à costa. No inverno o período entre 6-8 dias também é mais energético em ambas as componentes do vento e no espectro de pressão atmosférica.

A variação da pressão atmosférica na região é apresentada nas Figuras 4.33 e 4.34 para o verão de 2003 e inverno de 2004, respectivamente. As séries se destacam pela semelhança ao longo da costa, tanto no verão quanto no inverno. As localidades na porção sul da PCSE apresentam variações mais bruscas da pressão. Nota-se que os eventos de alteração de direção com ventos de sul com grandes intensidades são acompanhados de depressões no campo de pressão atmosférica, como exemplificado no verão para as datas de 07/01/2003, 20/01/2003 e 13/03/2003 e no período de inverno, 10/07/2004 e 05/09/2004. Destaca-se no inverno, também, um pico de elevada pressão atmosférica nas proximidades do dia 13/09/2004.

Nos espectros de potência da pressão atmosférica (Figura 4.35), para o verão, observam-se máximos de energia para os períodos de aproximadamente 5 dias, 8 dias e entre 15-40 dias. Para os locais ao sul de Cananéia, períodos entre 8-12 dias possuem máximos relativos de energia. Para o inverno, as maiores energias são observadas nos maiores períodos (maiores que 20 dias). Períodos entre 6-8 dias também são energéticos em todas as localidades. Ao sul de São Francisco, os períodos entre 6-14 dias possuem máximos relativos de energia. 

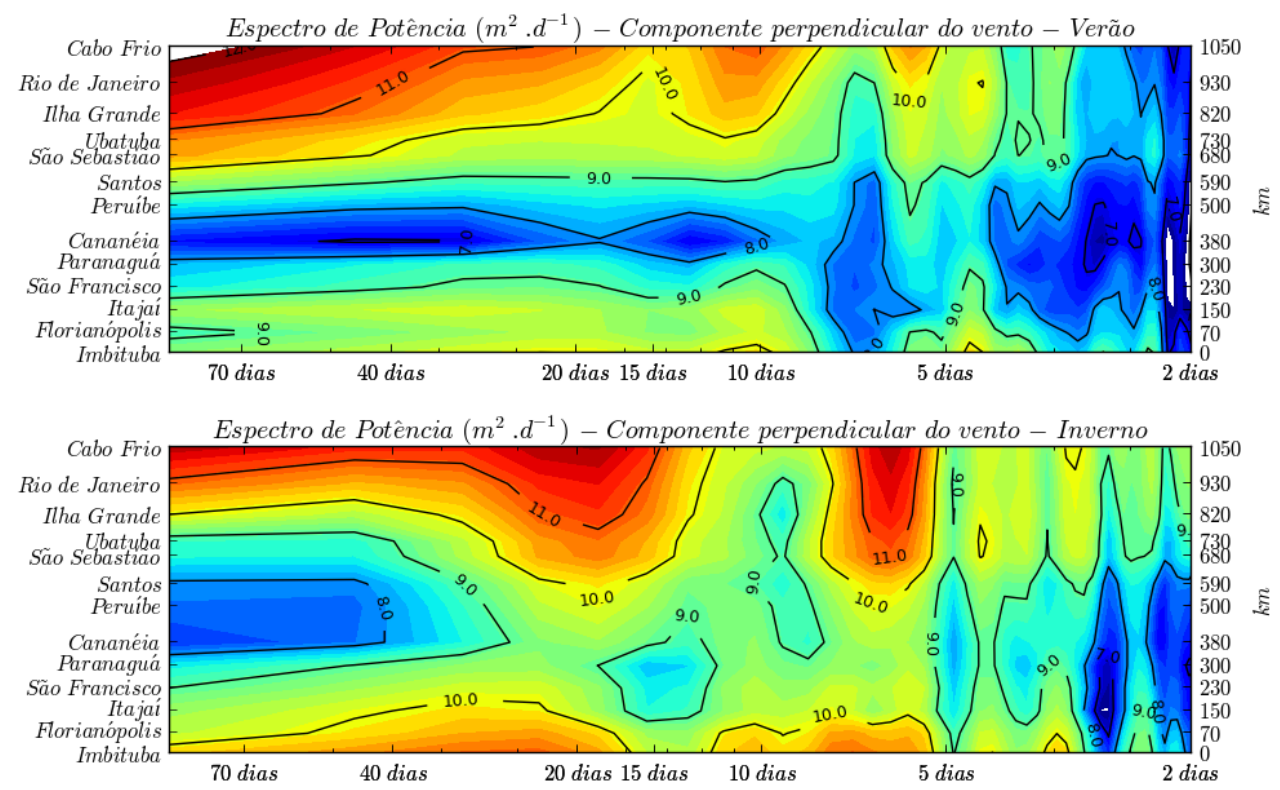

Figura 4.31: Isolinhas dos espectros de potência para a componente do vento perpendicular à costa para o verão de 2003 (superior) e inverno de 2004 (inferior), em função da distância ao longo da costa (ordenadas) e do período (abcissas). São apresentadas as potências mínimas com confiabilidade estatística de $95 \%$ e 10,5 graus de liberdade.
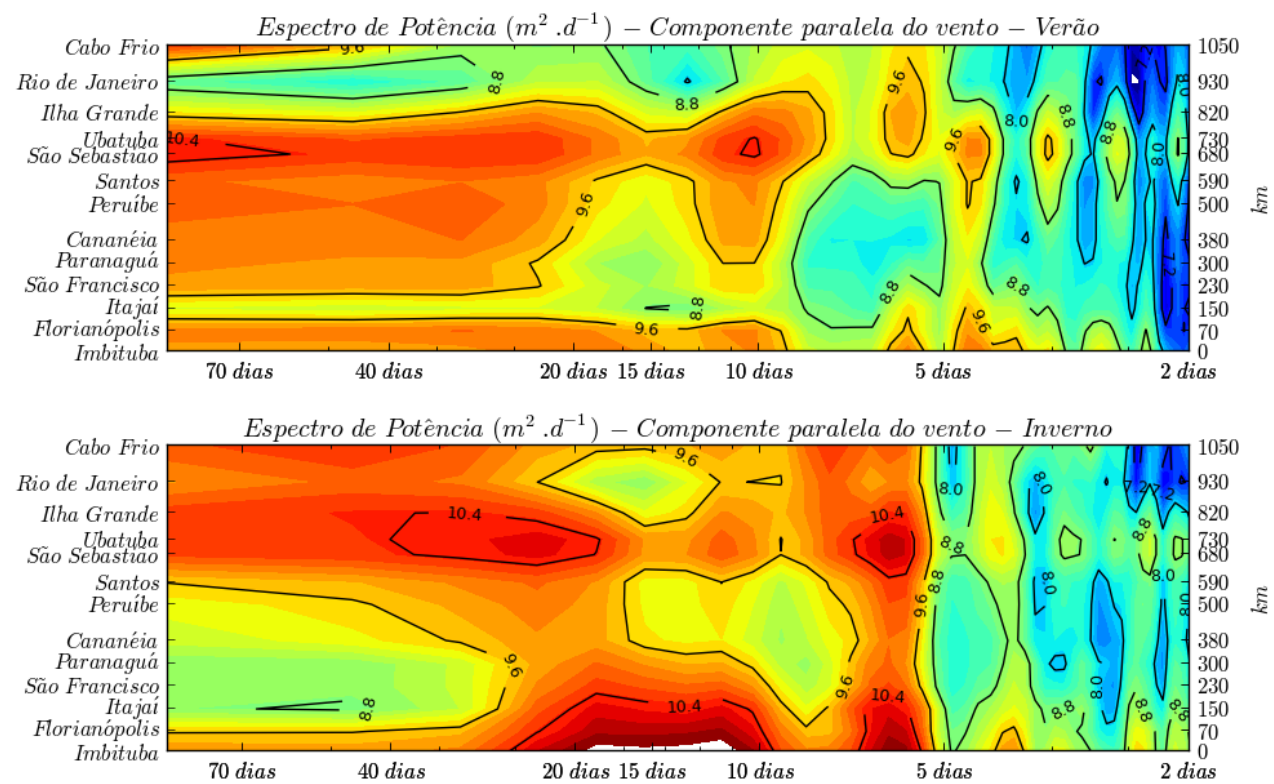

Figura 4.32: Isolinhas dos espectros de potência para a componente do vento paralelo à costa para o verão de 2003 (superior) e inverno de 2004 (inferior), em função da distância ao longo da costa (ordenadas) e do período (abcissas). São apresentadas as potências mínimas com confiabilidade estatística de $95 \%$ e 10,5 graus de liberdade. 


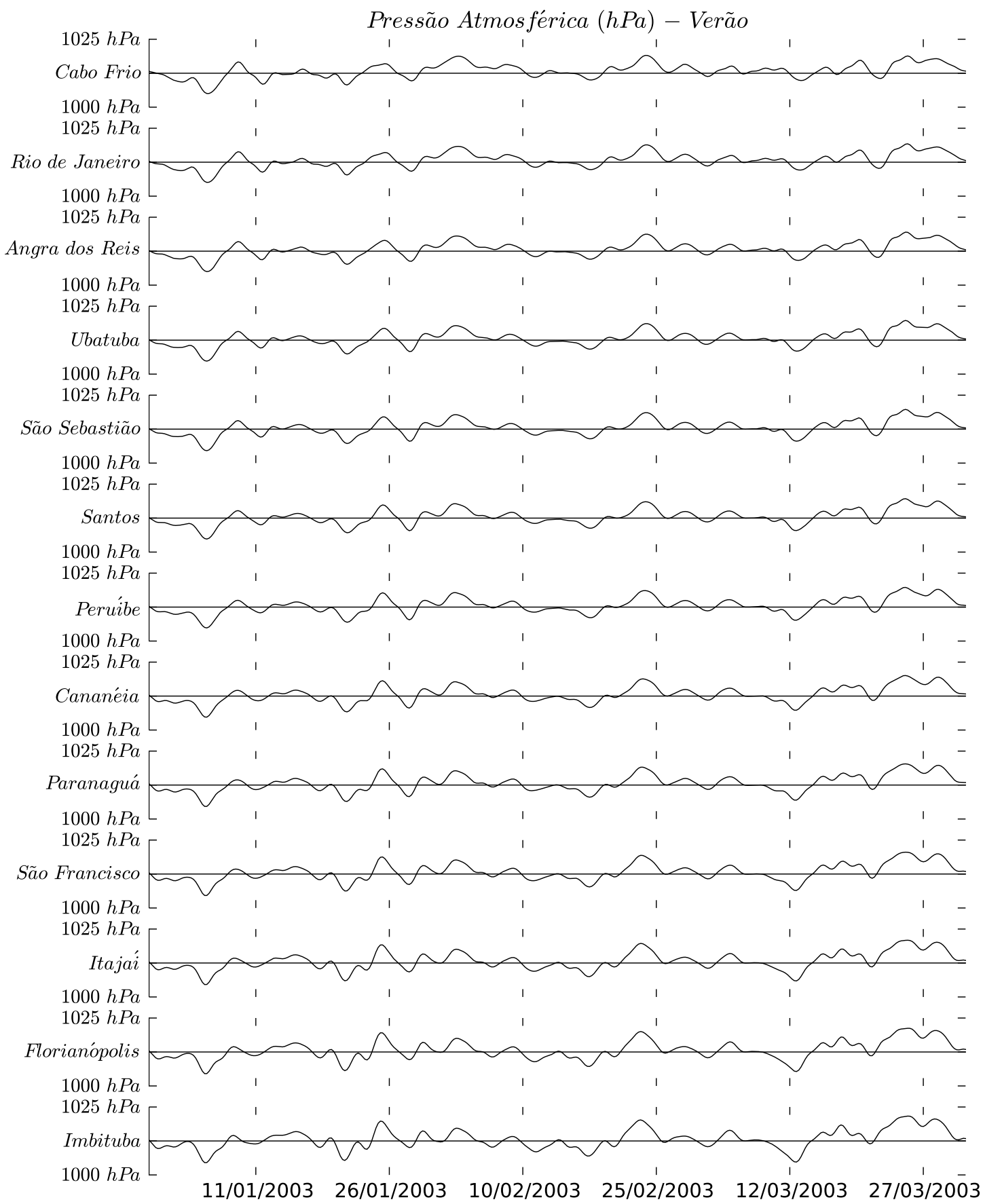

Figura 4.33: Pressão atmosférica subinercial no verão de 2003 nos locais descritos à esquerda dos gráficos. 


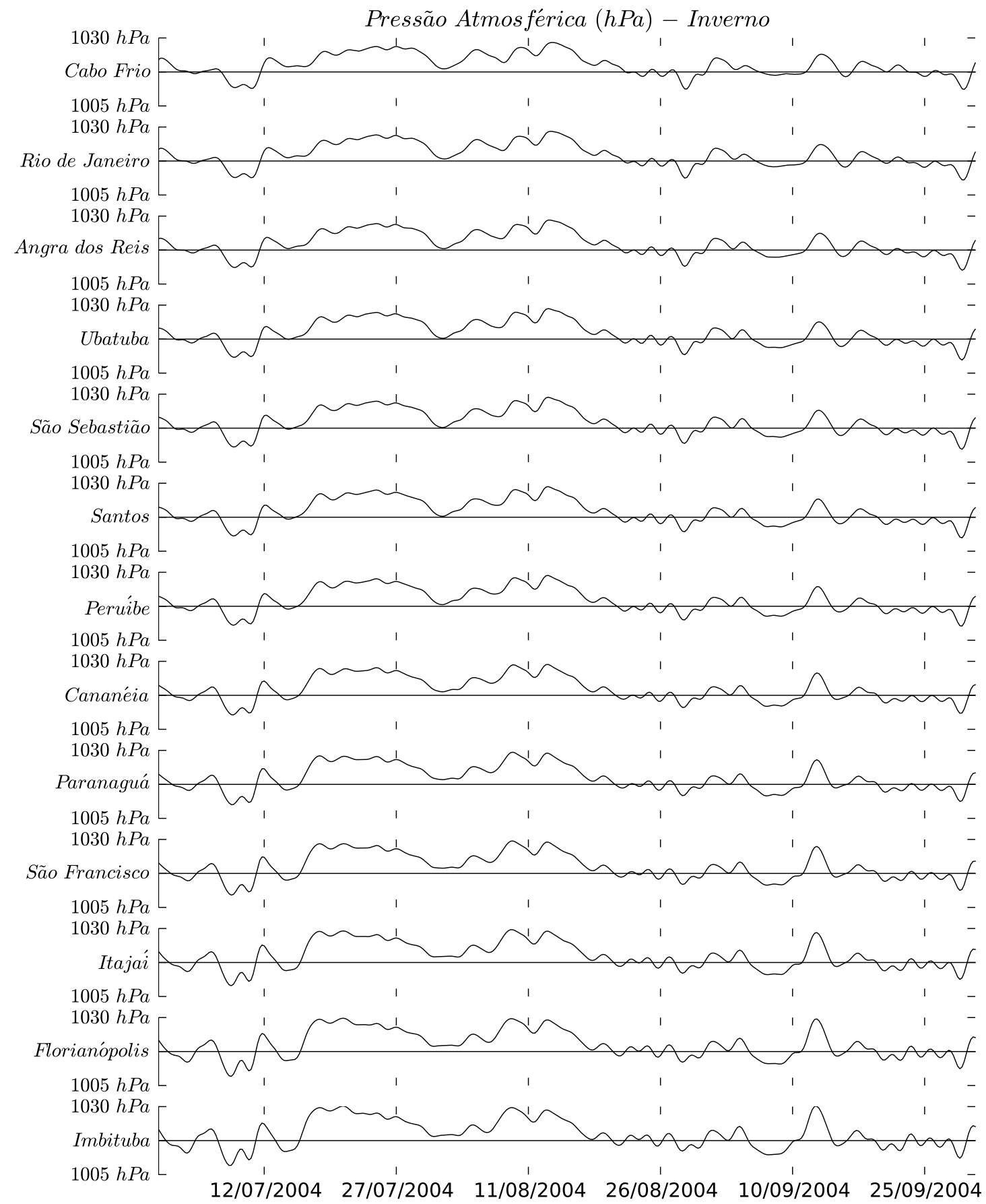

Figura 4.34: Pressão atmosférica subinercial no inverno de 2004 nos locais descritos à esquerda dos gráficos. 

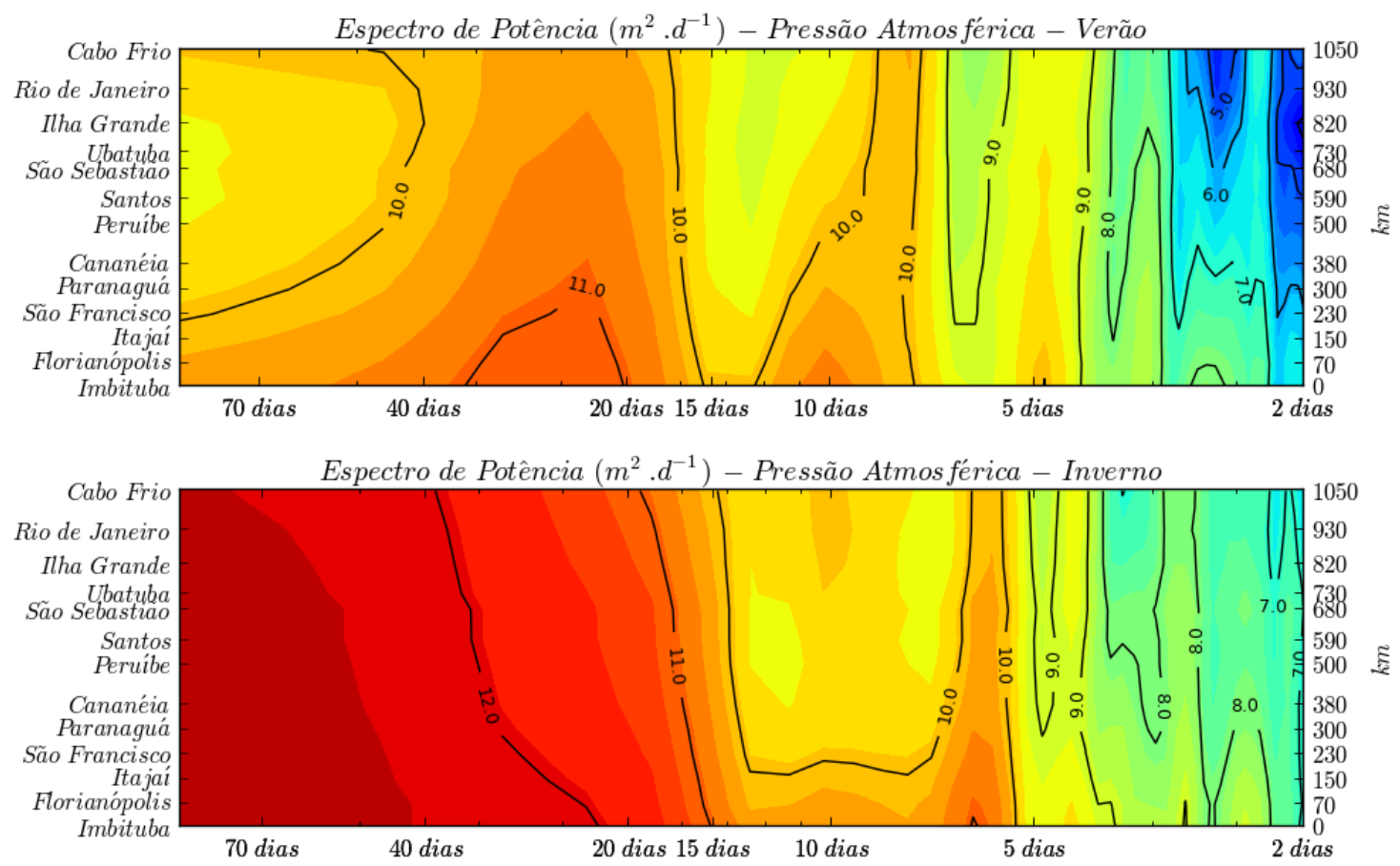

Figura 4.35: Isolinhas dos espectros de potência para pressão atmosférica para o verão de 2003 (superior) e inverno de 2004 (inferior), em função da distância ao longo da costa (ordenadas) e do período (abcissas). São apresentadas as potências mínimas com confiabilidade estatística de $95 \%$ e 10,5 graus de liberdade.

As variações subinerciais do nível do mar modeladas na costa da PCSE para o verão de 2003 (Figura 4.36) e para o inverno de 2004 (Figura 4.37) mostram maiores amplitudes para a região entre Cananéia e Santos; além disso, o inverno apresenta oscilações de maior amplitude do que o verão. Para ambas as estações do ano destaca-se a propagação das elevações do nível do mar, com eventos repetidos em todas as localidades, variando somente as amplitudes. No verão desta-se o período entre 14/01/2003 e 29/01/2003 com oscilações de grande amplitude, seguido por um período (até 15/03/2003) de relativa estabilidade. Nos 15 dias finais das séries foram modeladas, novamente, variação do nível do mar de grande amplitude. Para o período de inverno destacam-se 5 eventos de grande aumento do nível do mar (praticamente $1 \mathrm{~m}$, entre Peruíbe e São Sebastião), nos dias 12/07/2004, 18/07/2004, 09/08/2004, 13/09/2004 e 17/09/2004. Destacam-se, também, 3 eventos de rebaixamento do nível do mar, nos dias 14/07/2004, 14/08/204 e 14/09/2004. 


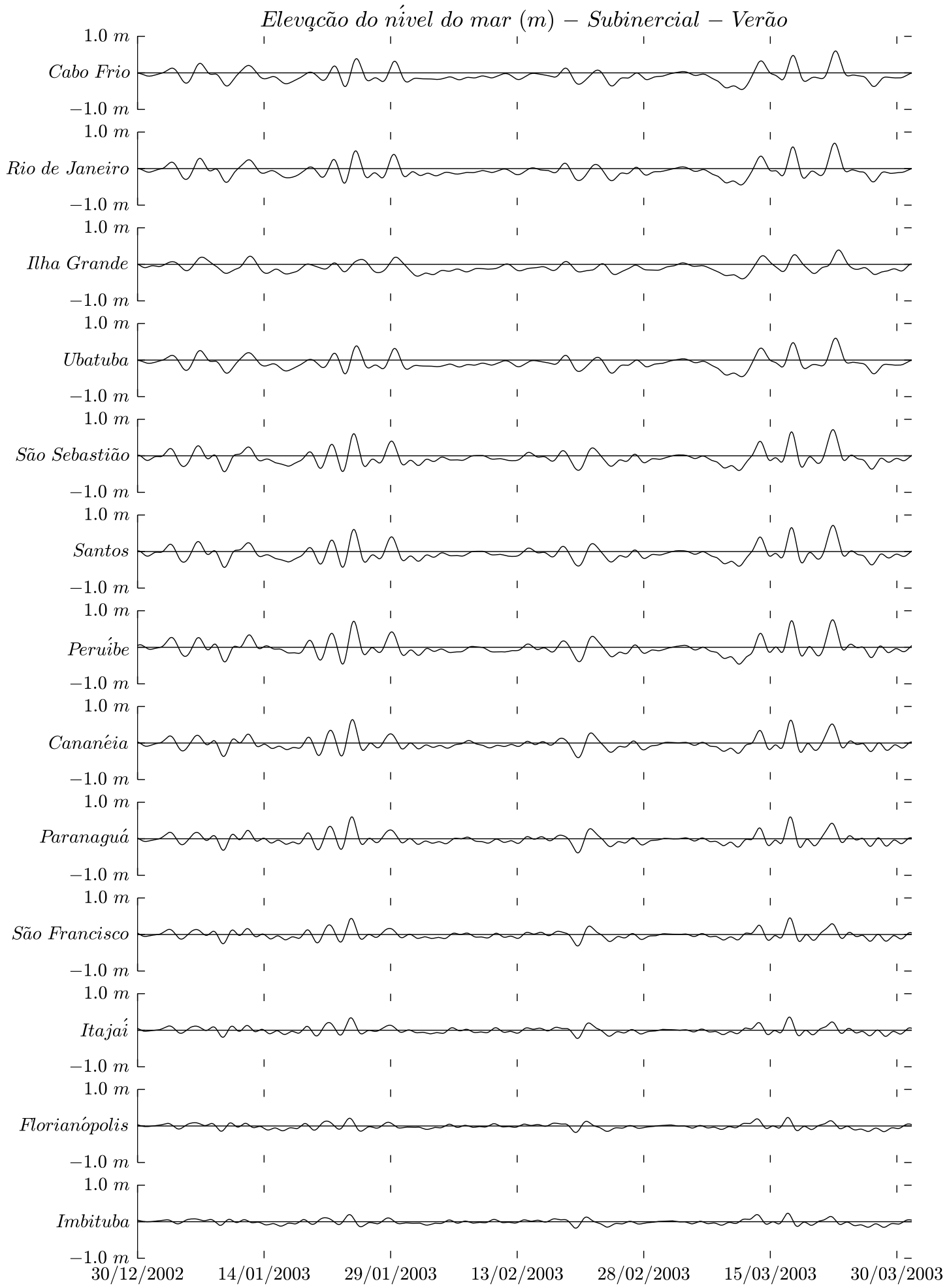

Figura 4.36: Nível do mar subinercial modelado no verão de 2003 (Experimento 1A), nos locais descritos à esquerda dos gráficos. 


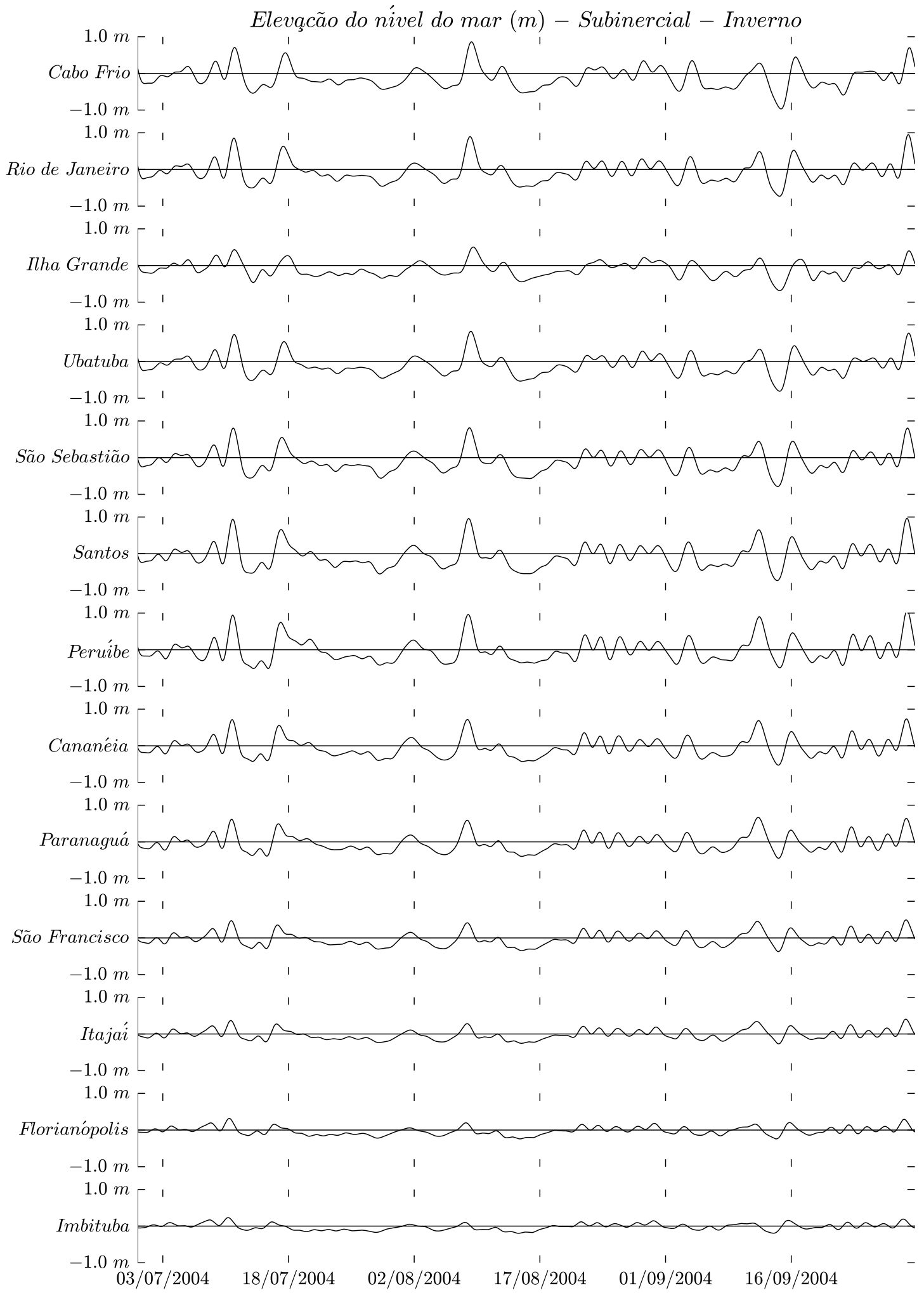

Figura 4.37: Nível do mar subinercial modelado no inverno de 2004 (Experimento 1B), nos locais descritos à esquerda dos gráficos. 
Para o espectro de potência da variação do nível do mar modelado na costa da PCSE (Figura 4.38), no verão, ao norte de Paranaguá, máximos de energia são observados para períodos de 3-5 dias, 7-9 dias e 17-19 dias, aproximadamente. Já pra o período de inverno, são destaque, para as localidades ao norte de São Francisco, os períodos de 3 dias, 4-5 dias e 5-8 dias. Exceto em Ilha Grande, ao norte de São Francisco os períodos de 10-20 dias tem destaque.
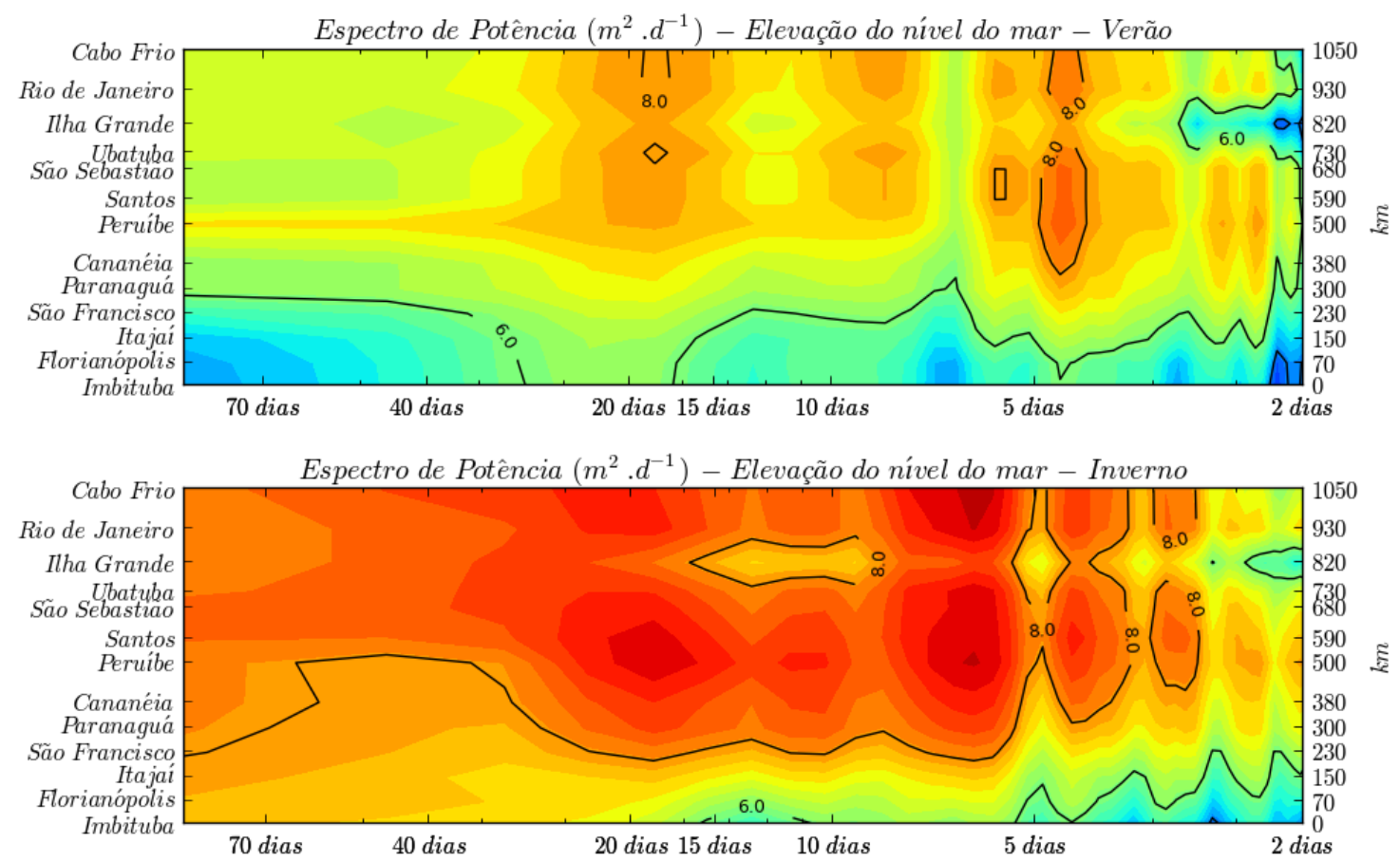

Figura 4.38: Isolinhas dos espectros de potência para a oscilação da superfície livre do mar para o verão de 2003 (superior) e inverno de 2004 (inferior), em função da distância ao longo da costa (ordenadas) e do período (abcissas). São apresentadas as potências mínimas com confiabilidade estatística de $95 \%$ e 10,5 graus de liberdade.

\subsection{Experimentos com passagens de frentes}

As variações subinerciais do nível do mar e das correntes verticalmente integradas resultantes dos Experimentos 2A e 2B (passagem de FF por toda a extensão da PCSE no verão e no inverno, respectivamente) são apresentadas nas Figuras $4.39 \mathrm{e}$ 4.40 .

Tanto para o experimento de verão quanto para o de inverno, a variação do nível do mar modelado durante a passagem da FF foi máxima nas proximidades da costa (máximos de $30 \mathrm{~cm}$ ), e apresentou decaimento em direção ao largo. As correntes verticalmente integradas inverteram a direção em toda a PCSE em aproximadamente $72 \mathrm{~h}$ (24 h após a FF passar por Imbituba). Foi modelada amplificação da 
oscilação do nível do mar conforme a FF se desloca para porção norte da PCSE, até aproximadamente a região de Peruíbe. O nível do mar e as correntes retornaram a valores comparáveis aos do início da simulação após 216 h (168 h após a FF passar por Imbituba).

Os resultados modelados para os experimentos com passagem de FF que não percorrem toda a extensão da PCSE, para o verão (Experimento 3A, Figura 4.41) e para o inverno (Experimentos 3B, Figura 4.42), mostram que a parte norte da PCSE é afetada indiretamente por essas perturbações atmosféricas sinóticas. As elevações positivas da superfície do mar, causadas por ventos do quadrante sul, propagam-se até o extremo norte da PCSE, associadas à inversão de sentido das correntes verticalmente integradas. Após a elevação positiva do nível do mar, ocorre a diminuição dessa elevação nas proximidades da costa, similarmente ao descrito para os experimentos que consideraram a passagem de FF por toda a extensão da PCSE (2A e 2B). As elevações positivas da superfície do mar atingem a porção norte da PCSE 24 h após a FF passar por Imbituba; as condições iniciais são restabelecidas após 216 h do início das simulações (168 h após a FF passar por Imbituba), evidenciando grande similaridade com os experimentos que simularam a passagem de FF por toda a extensão da PCSE, porém com amplitudes de elevações reduzidas. 

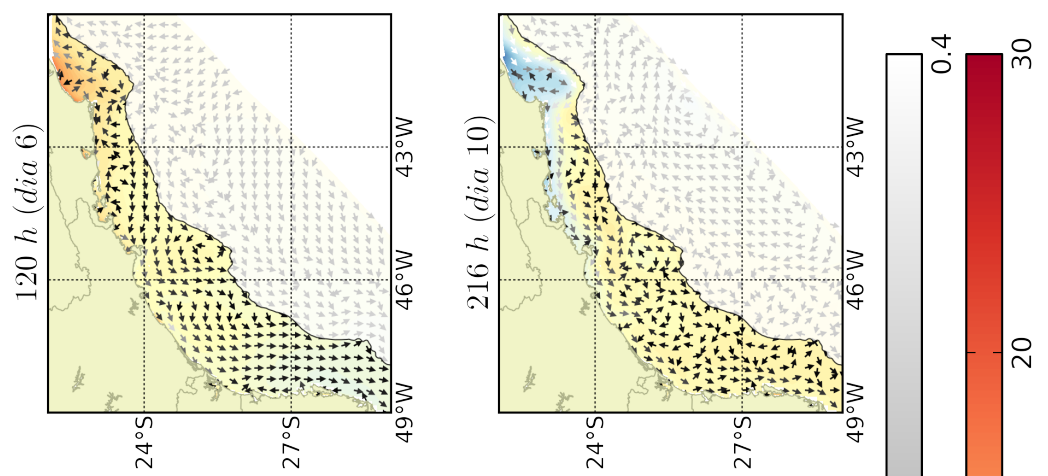

告

.

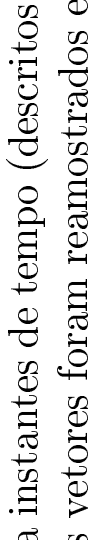
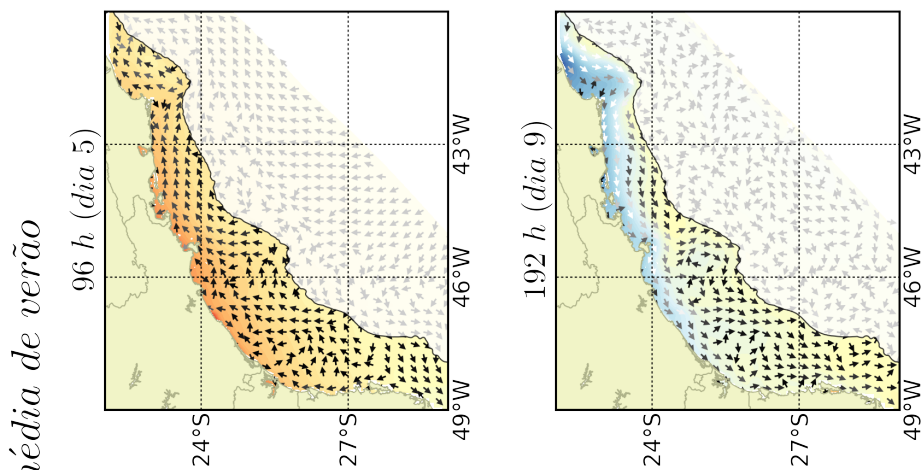

:

.

$\frac{\pi}{\pi}$

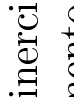

ज

क्ञ

๑

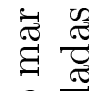
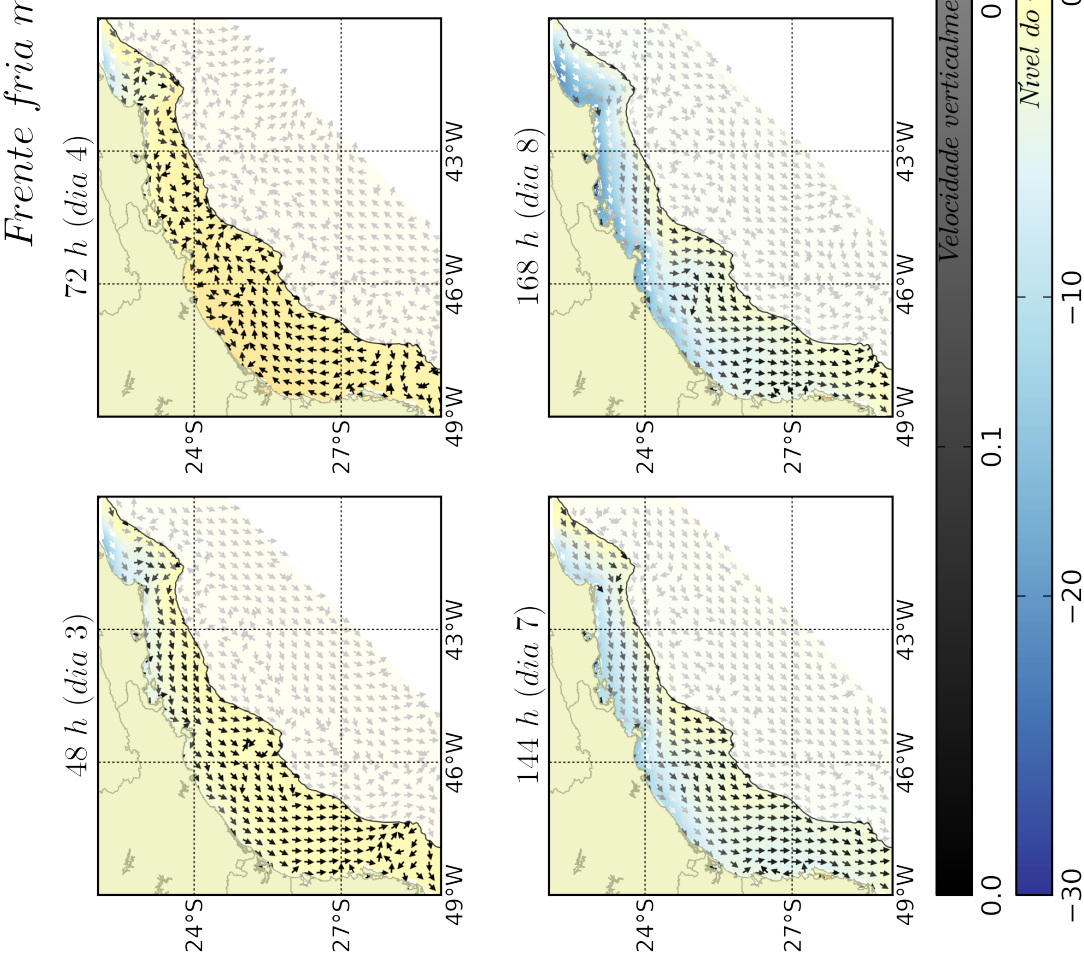

웜

坣

ช

क्ष

잉

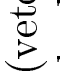

ซ్

50

.

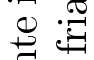

ฮี ญ

.

跑

○

青

ర

ค่

अ 2.

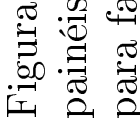



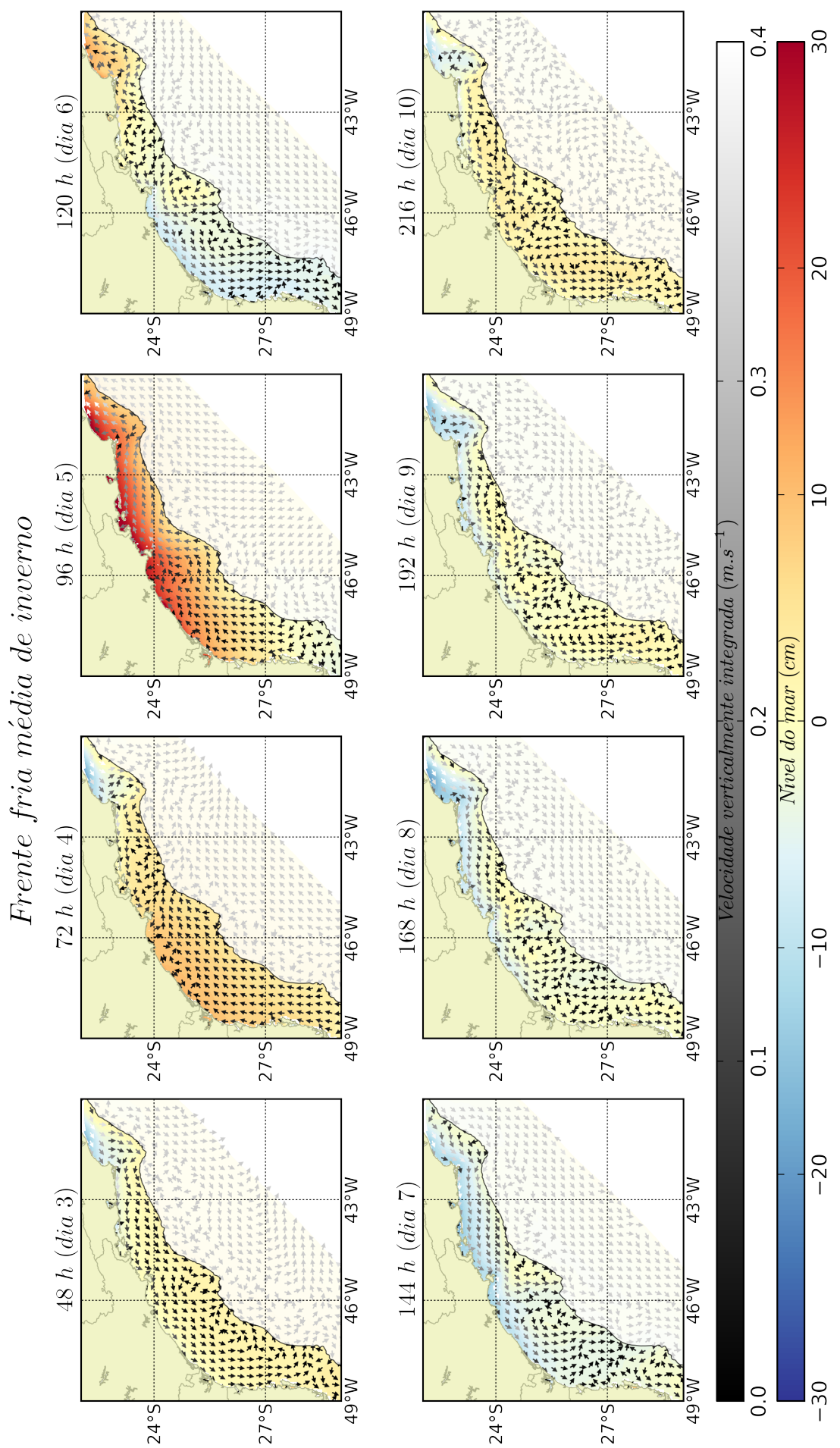

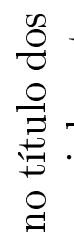

0
0
0
0
0
0

㐘

气્વ

ક્ง

ช

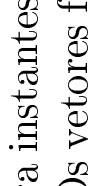

สँ

.

:

串

疍

ขี

过

䒕

웡

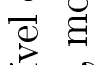

当。

.

递

웡

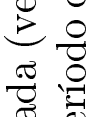

चु

\&

.$\Xi$

兄

छี

.

車

○ हृ

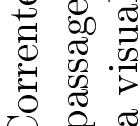

$\circlearrowright \quad \tilde{\sigma}$

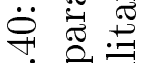

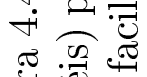

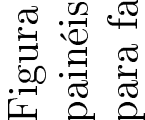



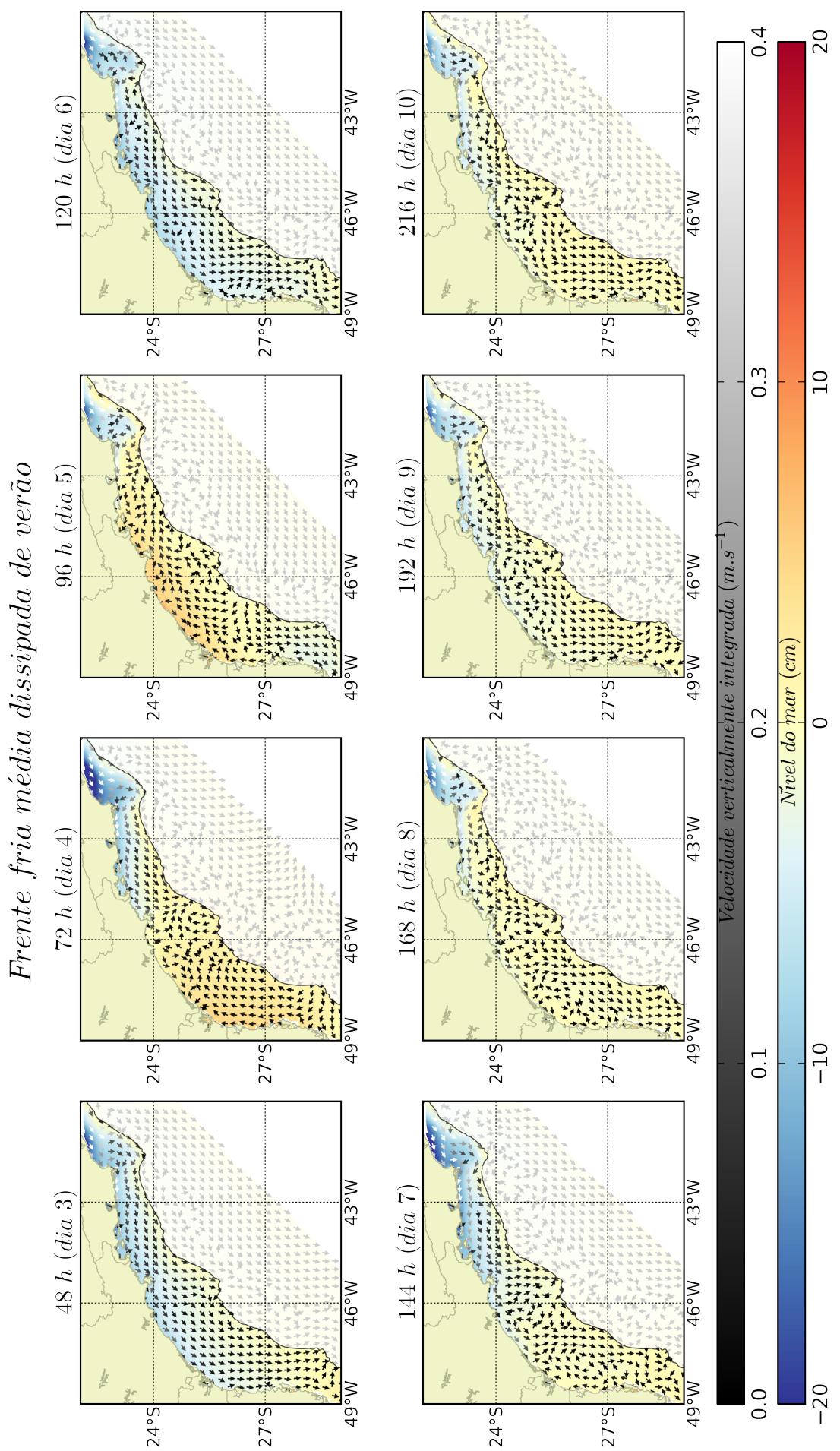

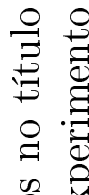

of

苞

弚 䨔

总

음

先 己

票

శี

. $\frac{\pi}{7}$

- 苞

光

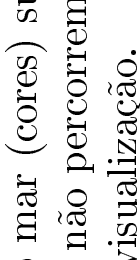

을

总

- $)$

đิ

유융

¿

चี ह

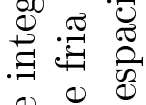

욤용

密

.

$=200$

怘 D

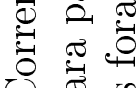

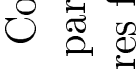

$\ddot{7} \overparen{0}$

मं :

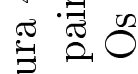
品 

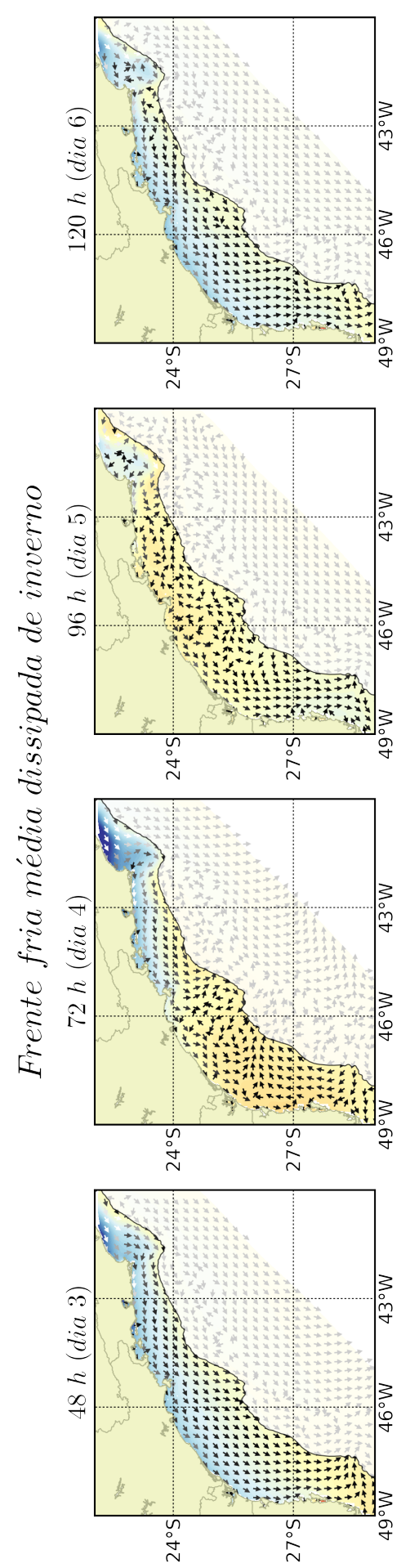
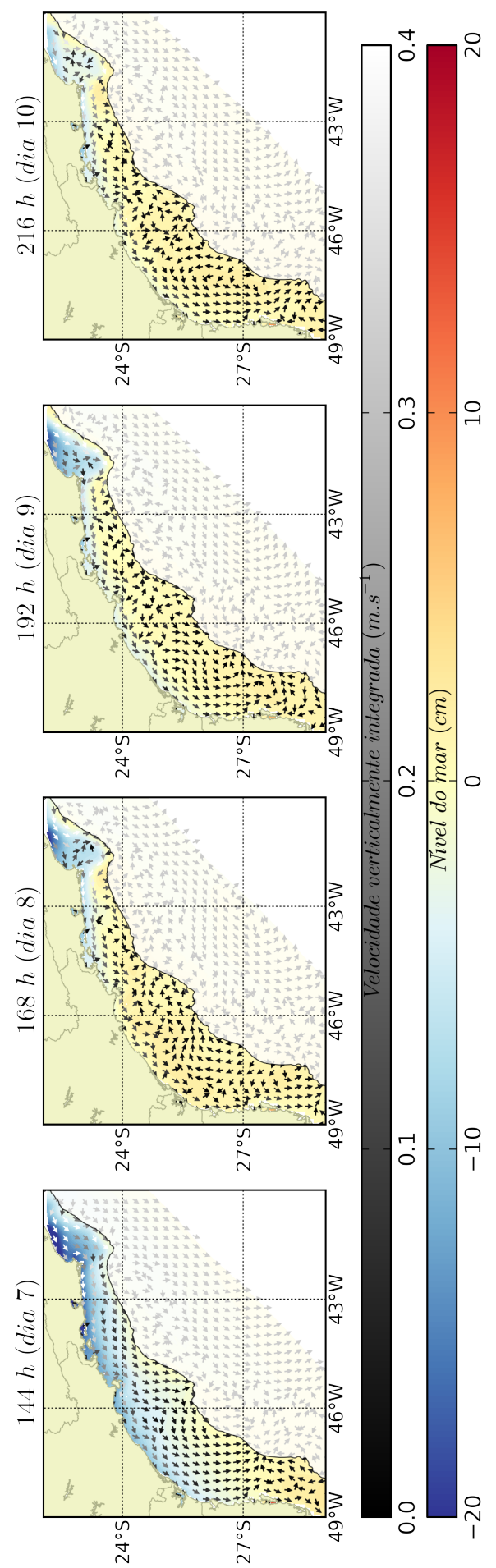

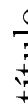

$\cong$

of

苞

异 क

융

Ð

응

己 च

范

.

䒕

疍

ن

Ðేّ

疍

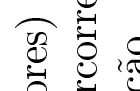

¿

丞

율

D

当苛:

(ี $)$

융

\&.

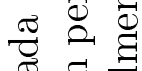

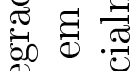

. 范苛

总怘

है

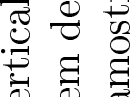

苟

唄

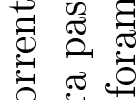

ঠं

$\ddot{\sim} \overparen{0}$

ㄱ:

$\stackrel{\varpi}{\Xi} \mathscr{0}$

if 


\section{Capítulo 5}

\section{Discussão}

\subsection{Bancos de dados atmosférico e oceânico}

Os resultados de comparação entre os dados meteorológicos coletados em estações e os do BDA mostraram boa correlação, tanto para as séries totais (Figura 5.1) quanto para a porção subinercial do espectro (Figura 5.2). As melhores concordâncias entre estes dois conjuntos foram obtidas para a pressão atmosférica, com grandes correlações em todas as localidades, tanto na faixa subinercial do espectro quanto na série total. Para as componentes da velocidade do vento, as séries subinerciais tiveram valores mais elevados de correlação, quando comparadas aos valores para as séries totais.

De modo geral os cálculos estatísticos de comparação entre o BDA e dados coletados apresentaram melhores resultados na região costeira do que na região oceânica, sobretudo para pressão atmosférica e para a componente do vento paralela à costa. As piores comparações foram obtidas na região oceânica ao largo de Santos (Santos - PNBOIA e Laje de Santos - ECOSAN); as correlações calculadas para a componente do vento perpendicular à costa foram superiores a 0,5 somente em Imbituba PNBOIA. Neste estudo obtivemos discrepâncias entre as direções dos ventos coletados em estações e as do BDA. Skielka (2007) realizou comparações entre dados da reanálise do NCEP e coletados em estações, mas na região oceânica nordeste do Brasil, encontrando grande similaridade entre as séries. Menezes (2007) e Cavalcante (2010) comparam dados de ventos coletados em estações costeiras do RJ com dados da reanálise do NCEP e também observaram discrepâncias na direção dos ventos. Estes dois últimos autores atribuíram tal diferença a efeitos orográficos inexistentes no modelo global. Costa (2010) utilizou quatro pontos de grade da reanálise do NCEP, a diferentes distâncias da costa do PR, para estudar a variação do nível do mar. Para os pontos mais próximos da região costeira os resultados obtidos pelo último autor não foram satisfatórios, levando-o a concluir que nas regiões costeiras a 
resolução do modelo global não é suficiente para resolver a influência do continente sobre a circulação atmosférica costeira. Esta interferência orográfica já havia sido observada por Castro \& Lee (1995)também em dados meteorológicos coletados na PCSE levando os autores a descartar dados de ventos das estações que apresentaram interferência orográfica por não serem representativos dos ventos sinóticos e de larga escala que forçam movimentos na PCSE.

É importante ressaltar que neste estudo foram utilizadas séries temporais de dados coletados em estações épocas diferente e com extensões distintas e, como mostrado na Tabela 3.1, as séries coletadas em estações costeiras são mais extensas (mínimo de 5 meses em Santos - PRATICAGEM e máximo de 7 anos no Rio de Janeiro - METAR) do que aquelas coletadas em estações oceânicas (mínimo de 2 meses em Santos - PNBOIA e máximo de 9 meses na Laje de Santos - ECOSAN). Portanto, a maior representatividade da realidade das séries para a região costeira com relação à oceânica, pode ter contribuído para que os resultados de comparação fossem melhores para a região costeira.

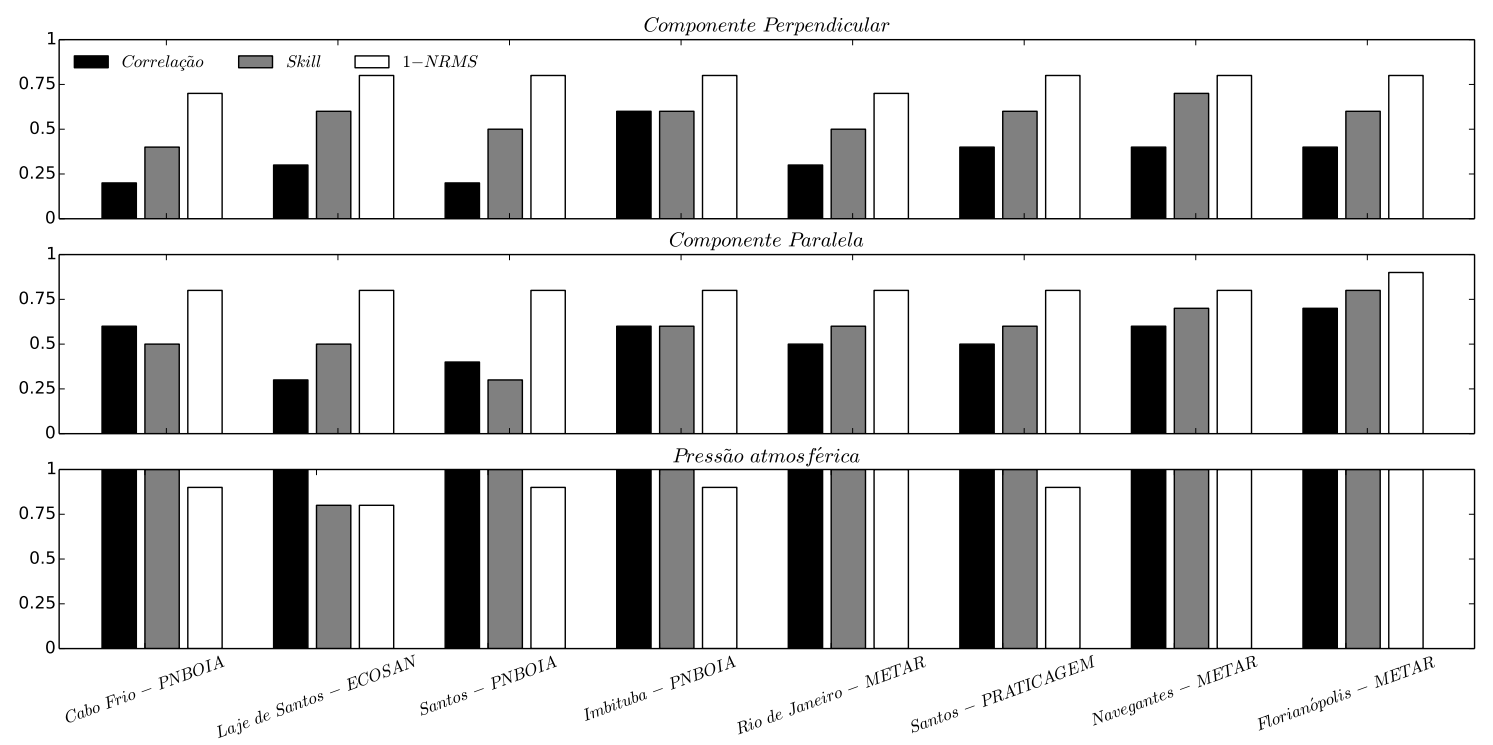

Figura 5.1: Resultados dos métodos estatísticos de comparação entre dados totais coletados e o BDA. O painel superior mostra as comparações para a componente do vento perpendicular à costa, o central para a componente do vento paralela à costa e o painel inferior a comparação para a pressão atmosférica. 


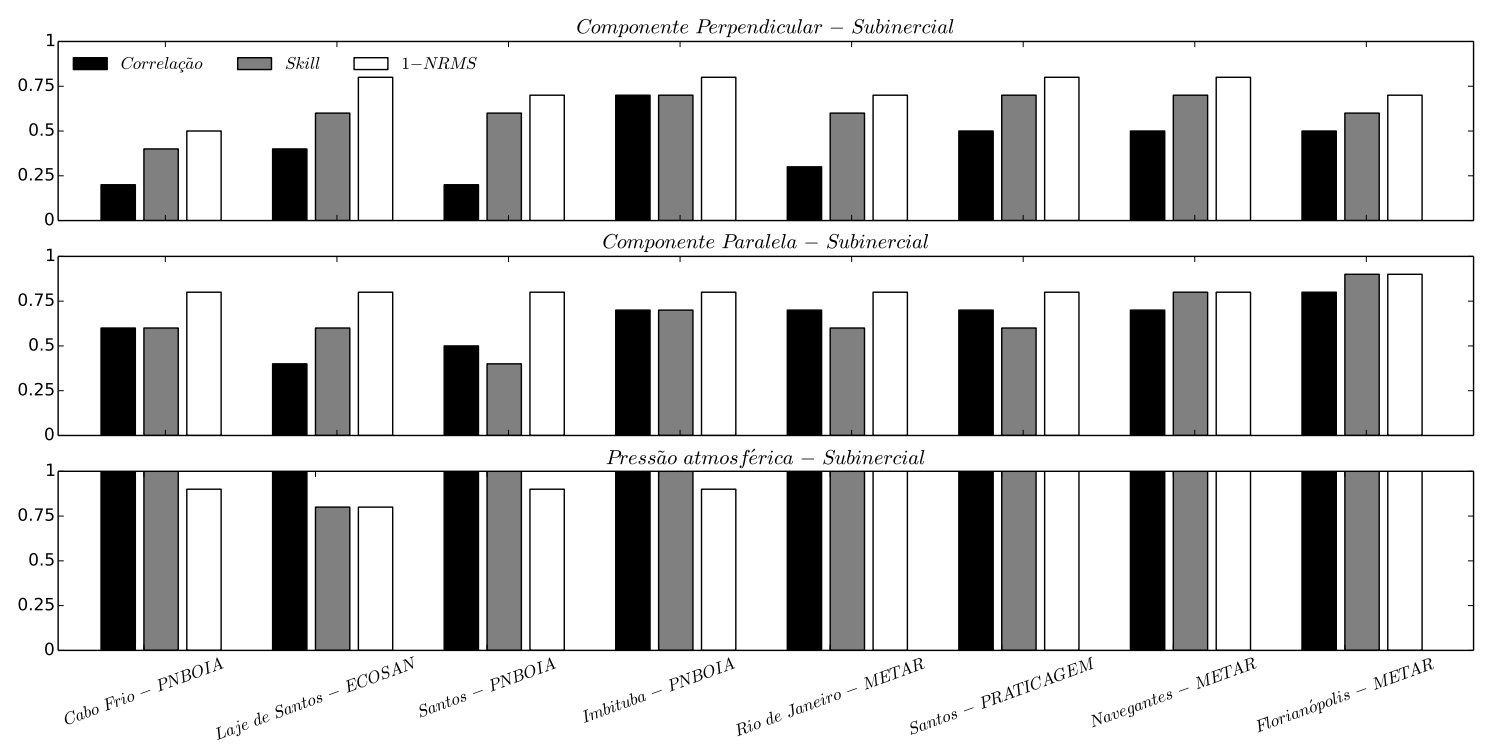

Figura 5.2: Resultados dos métodos estatísticos de comparação entre dados subinerciais coletados e o BDA. O painel superior mostra as comparações para a componente do vento perpendicular à costa, o central para a componente do vento paralela à costa e o painel inferior a comparação para a pressão atmosférica.

A comparação entre os valores extremos das componentes do vento paralela e perpendicular à costa, tanto na região costeira quanto na região oceânica, indicou que, exceto no Rio de Janeiro - METAR, os dados coletados em estações são mais intensos do que do BDA. Silva (2013) observou a mesma discrepância em valores extremos ao comparar dados da reanálise do NCEP com modelo atmosférico regional e dados observacionais na Bacia de Campos (norte da PCSE). Esta autora concluiu que os valores extremos da reanálise são inferiores aos do modelo regional (que melhor se aproximou dos dados coletados). Rao et al. (2002) e Vasques et al. (2009) concluíram que os dados da reanálise do NCEP não reproduzem corretamente a intensidade e orientação da Zona de Convergência do Atlântico Sul.

Em síntese, a extensa comparação entre dados coletados em estações e dados da reanálise NCEP-DOE AMIP II realizada neste trabalho apresentou índices satisfatórios; entretanto, é importante ressaltar que valores extremos da intensidade do vento nas direções perpendiculares à costa apresentam discrepância entre os dados coletados em estações e os do BDA. Contudo, como estamos analisando fenômenos meteorológicos de larga escala e escala sinótica, as comparações indicam que o BDA representa bem os fenômenos físicos nessas escalas sobre a PCSE, conforme também concluiu Andrade (2007). Este BDA, entretanto, deve ser utilizado com ressalvas em regiões costeiras ou em estudos de pequena escala.

A comparação estatística entre as séries totais de elevação da superfície do mara modeladas e observadas (Figura 5.3 indica boa correlação. Os valores mínimos para 
a correlação e skill foram superiores a 0,7 e,para NRMS os valores foram inferiores a 0,2. As comparações entre valores medidos e modelados na banda subinercial (Figura 5.4 foram inferiores às das séries totais, principalmente em Imbituba GLOSS Brasil. Nessa banda, os resultados de correlação variaram de 0,1 (Imbituba - GLOSS Brasil no verão) a 0,6 (Cananéia - GLOSS Brasil, Ubatuba - IOUSP e Rio de Janeiro - GLOSS Brasil no inverno).
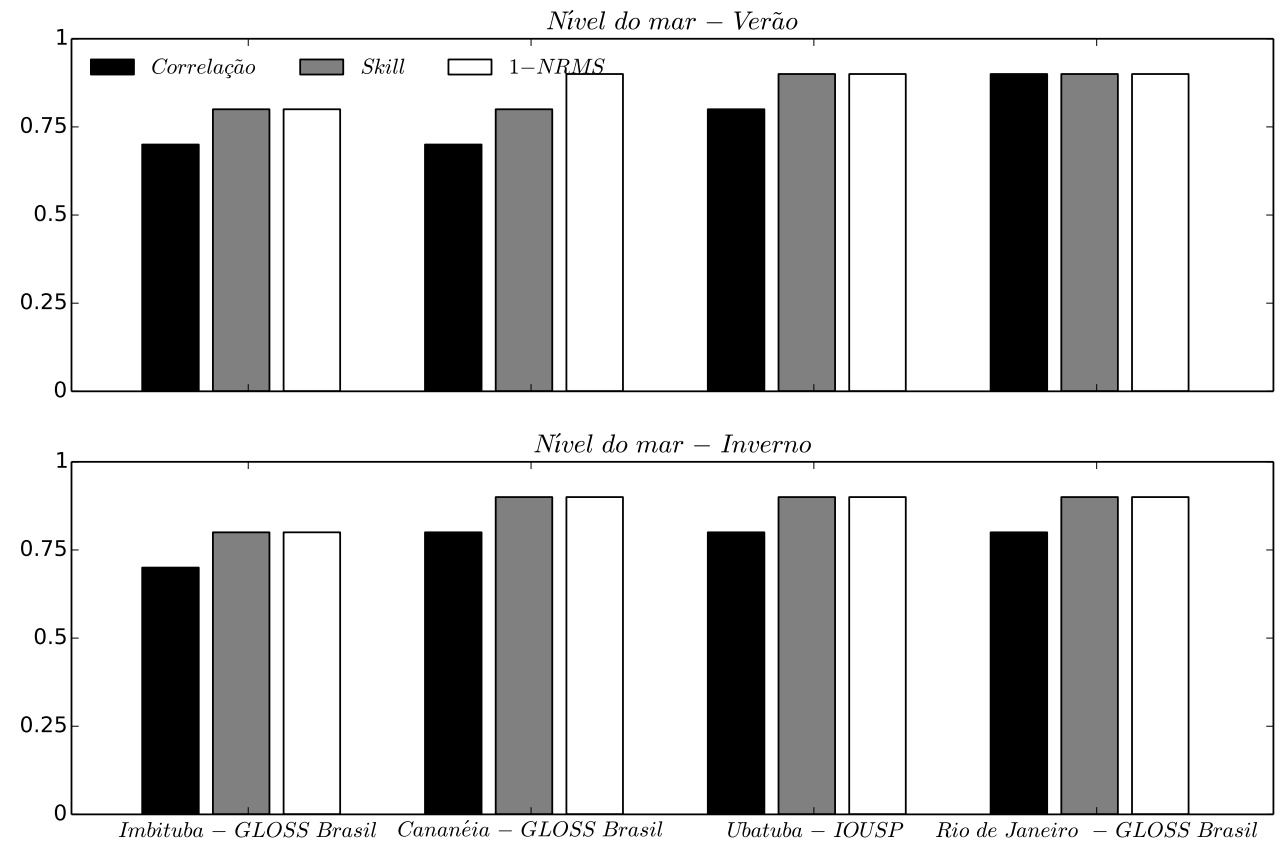

Figura 5.3: Resultados dos métodos estatísticos de comparação entre dados totais coletados e o BDO (experimentos numéricos). O painel superior mostra a comparação para a elevação da superfície do mar, no verão, e o painel inferior para a elevação da superfície do mar no inverno

Diversos autores estudaram OS da superfície livre do mar na PCSE e, exceto em Imbituba - GLOSS BRASIL, os resultados modelados aqui são similares aos observados e modelados por outros autores. Para a porcentagem da variância total explicada pela banda subinercial do espectro, Castro \& Lee (1995) encontraram, a partir de observações, valores variando entre 16 a $30 \%$ para diversos locais da PCSE. Esses valores foram confirmados posteriormente por Oliveira (2004), Uaissone (2004) e Cavalcante (2010) para a costa dos estados do RJ e do PR. Campos et al. (2010) encontraram OS de amplitude máxima próxima a 0,8 m em Santos, valor similar aos encontrados por Valentim (2012) em Ubatuba e Uaissone (2004) na Baía da Ilha Grande. Oliveira et al. (2007) e Costa (2010) encontraram oscilações com amplitude de cerca de 0,7 cm em Cananéia e Paranaguá. Os valores de modelagem e observados por França (2013) no Rio de Janeiro e em Cananéia, e os observados por Filippo (2003), Filippo et al. (2012), também são muito similares aos modelados 
aqui. Cavalcante (2010) modelando as variações subinerciais da superfície livre do mar na Baía da Ilha Grande obteve erros variando entre 30\% e 50 \% e França (2013), embora não tenha quantificado a diferença entre os dados modelados e observados, obteve boa correlação em Imbituba, Cananéia, Rio de Janeiro e Macaé. Camargo \& Harari (1994) obtiveram valores de correlação entre nível medido e modelado na PCSE variando de 0,6 em Paranaguá a 0,9 no Rio de Janeiro. Em outras PC comparação entre OS da superfície livre do mar modeladas observadas apresentaram índices comparativos similares aos deste estudo, como por exemplo, Martinez \& Allen (2004), NOAA (2011), Huang (2011) e Medeiros et al. (2013) que tiveram valores de skill variando entre 0,3 e 0,9 e de NRMS entre 0,1 e 0,2 .
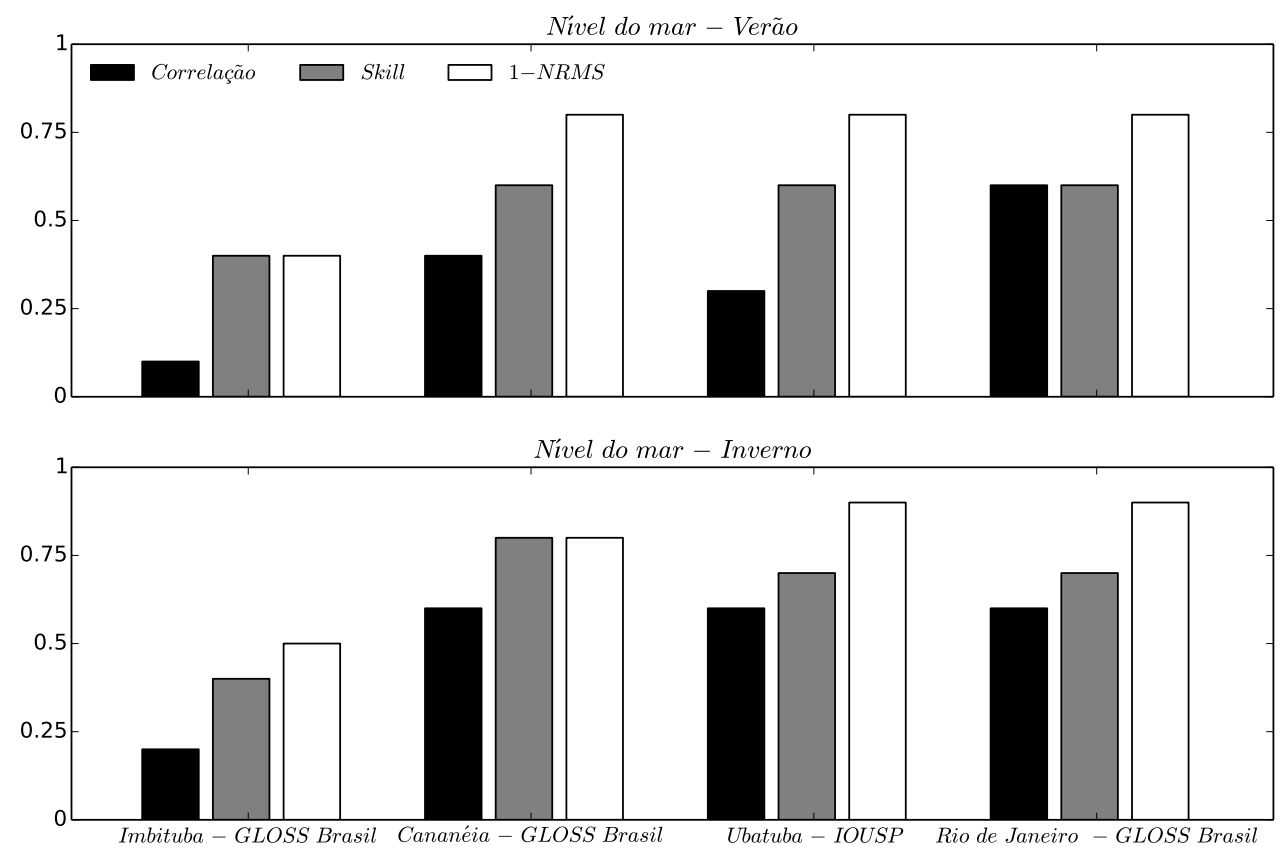

Figura 5.4: Resultados dos métodos estatísticos de comparação entre dados subinerciais coletados e o BDO (experimentos numéricos). O painel superior mostra a comparação para a elevação da superfície do mar, no verão, e o painel inferior para a elevação da superfície do mar no inverno

\subsection{Padrões atmosféricos}

Os campos de ventos médios estabelecidos (Figura 4.18) concorda com a circulação do ASAS sobre a PCSE. Este centro de alta pressão, que possui giro anticiclônico, faz com que a PCSE receba ventos de origem nordeste-leste. Quanto à intensidade dos ventos médios, foi observado que, principalmente na porção sul da PCSE, estes são menos intensos no inverno que no verão em decorrência da maior quantidade de passagens de FF na estação fria. No inverno, o número de ocorrência 
de FF na região sudeste do Brasil é mais elevado que no verão. Conforme discutido anteriormente, a passagem de FF sobre a PCSE faz com que os ventos tenham sua direção alterada, de nordeste-leste (período sem FF) para sul-sudoeste (durante a passagem das FF). Assim, quando calculada a média temporal dos vetores ventos, as componentes positivas e negativas compensam-se, obtendo-se assim um baixo valor, similarmente aos resultados obtidos por Samuels \& Cox (1987), Castro (1996), Wainer \& Tascheto (2006). No verão, o menor número de FF causa menos inversões do vento. Esta maior variabilidade temporal dos ventos devido à passagem de FF, principalmente na porção sul da PCSE, foi quantificada com o cálculo da variância da componente meridional (Figura 4.20) do vento, que mostrou que no inverno os valores são superiores aos do verão.

A sazonalidade dos campos médios de temperatura atmosférica é evidenciada (Figura 4.21), com maiores valores no verão; na porção norte da PCSE a amplitude térmica anual é de aproximadamente $6^{\circ} \mathrm{Ce}$, na porção sul, $8^{\circ} \mathrm{C}$. Principalmente na região costeira e na porção centro-sul da PCSE, as variâncias das temperaturas atmosféricas são maiores no inverno que no verão (Figura 4.22). Este fato também está associado às passagens de FF que, junto coma a rotação do vento de nordesteleste para sul-sudoeste, ocasionam quedas na temperatura atmosférica.

A sazonalidade obtida para os campos médios de pressão atmosférica, está ainda ligada à migração longitudinal do ASAS. No verão o ASAS desloca-se em direção ao continente Africano, afastando-se da PCSE e fazendo com que as pressões médias sejam relativamente baixas. O oposto é verificado em período de inverno, quando o ASAS aproxima-se da região da PCSE fazendo que a pressão atmosférica média seja superior à observada no verão. A diferença média observada entre os períodos de verão e de inverno foi de $8 \mathrm{hPa}$ (Figura 4.23). Além disso, a pressão atmosférica é alterada também pela passagem de FFs. Assim, as variâncias calculados para o inverno foram máximas principalmente na região sul da PCSE.

As Tabelas 5.1 e 5.2 apresentam as quantidades de FF identificadas neste estudo nos pontos NORTE e SUL (Figura 3.3) e os valores obtidos do Boletim Climanálise do Centro de Previsão de Tempo e Estudos Climáticos do Instituto Nacional de Pesquisas Espaciais (CPTEC/INPE) em meses de verão e inverno, para os anos entre 1996 e 2011 (período disponível da publicação). Para os meses de verão, os resultados obtidos neste estudo e os descritos pelo Boletim Climanálise são similares, com números mínimos em fevereiro e máximos em março. A discrepância entre as médias foi menor no mês de março: $2,1 \pm 1,0 \mathrm{FF}$ neste estudo e 1,8 $\pm 1,5 \mathrm{FF}$ no Climanálise. Para os meses de inverno, as diferenças entre os valores obtidos neste estudo e no Boletim Climanálise são menores, sendo os valores idênticos para o mês de agosto (2,7 FF). Ainda, os resultados obtidos aqui são similares aos de Stech \& Lorenzzetti (1992) para o inverno dos anos de 1982 a 1985: 44 FF contra 47 FF, 
respectivamente.

Uma possível razão para as diferentes quantidades de FF identificadas neste estudo e as reportadas no Boletim Climanálise é o método de identificação de FF. Neste estudo utilizamos método objetivo e automatizado aplicado aos dados da Reanálise do NCEP-DOE AMIP II, enquanto que no Boletim Climanálise a identificação das FF é realizada por meio de imagens de satélite e dados de estações meteorológicas. O método observacional empregado pelo Boletim Climanálise apresenta maior precisão pois avalia valores medidos. Os dados da Reanálise do NCEP-DOE AMIP II, embora coerentes espacialmente, não tem resolução suficiente para processos de pequenas escala.

Tabela 5.1: Parâmetros estatísticos comparativos entre o número de frentes frias identificadas em período de verão nos pontos SUL (S), NORTE (N) (Figura 3.3) e o mesmo número retirado do Boletim Climanálise do CPTEC/INPE. Total refere-se ao número total de frentes frias entre 1996 e 2011, Média é a média mensal para esses mesmos anos e Desvio é o desvio padrão da média.

\begin{tabular}{|c|c|c|c|c|c|c|c|c|c|c|c|c|}
\hline & \multicolumn{6}{|c|}{ Verão (1996-2011) } & \multicolumn{6}{|c|}{ Verão (1996-2011) - Climanálise } \\
\hline & \multicolumn{2}{|c|}{ Janeiro } & \multicolumn{2}{|c|}{ Fevereiro } & \multicolumn{2}{|c|}{ Março } & \multicolumn{2}{|c|}{ Janeiro } & \multicolumn{2}{|c|}{ Fevereiro } & \multicolumn{2}{|c|}{ Março } \\
\hline & $\mathrm{S}$ & $\mathrm{N}$ & $\mathrm{S}$ & $\mathrm{N}$ & $\mathrm{S}$ & $\mathrm{N}$ & $\mathrm{S}$ & $\mathrm{N}$ & $\mathrm{S}$ & $\mathrm{Ne}$ & $\mathrm{S}$ & $\mathrm{N}$ \\
\hline Total & 54 & 19 & 47 & 16 & 57 & 29 & 49 & 28 & 40 & 24 & 46 & 25 \\
\hline Média & 3,4 & 1,2 & 2,9 & 1,0 & 3,6 & 1,8 & 3,1 & 1,8 & 2,5 & 1,6 & 2,9 & 1,7 \\
\hline Desvio & 1,1 & 0,9 & 1,2 & 0,9 & 0,7 & 1,1 & 1,8 & 1,3 & 1,3 & 1,3 & 1,5 & 1,4 \\
\hline
\end{tabular}

Tabela 5.2: Parâmetros estatísticos comparativos entre o número de frentes frias identificadas em período de inverno nos pontos SUL (S), NORTE (N) (Figura 3.3) e o mesmo número retirado do Boletim Climanálise do CPTEC/INPE. Total refere-se ao número total de frentes frias entre 1996 e 2011, Média é a média mensal para esses mesmos anos e Desvio é o desvio padrão da média.

\begin{tabular}{|c|c|c|c|c|c|c|c|c|c|c|c|c|}
\hline & \multicolumn{6}{|c|}{ Inverno (1996-2010) } & \multicolumn{6}{|c|}{ Inverno (1996-2010) - Climanálise } \\
\hline & \multicolumn{2}{|c|}{ Julho } & \multicolumn{2}{|c|}{ Agosto } & \multicolumn{2}{|c|}{ Setembro } & \multicolumn{2}{|c|}{ Julho } & \multicolumn{2}{|c|}{ Agosto } & \multicolumn{2}{|c|}{ Setembro } \\
\hline & $\mathrm{S}$ & $\mathrm{N}$ & $\mathrm{S}$ & $\mathrm{N}$ & $\mathrm{S}$ & $\mathrm{N}$ & S & $\mathrm{N}$ & $\mathrm{S}$ & $\mathrm{N}$ & $\mathrm{S}$ & $\mathrm{N}$ \\
\hline Total & 52 & 44 & 49 & 34 & 56 & 48 & 65 & 40 & 63 & 41 & 58 & 56 \\
\hline Média & 3,3 & 2,8 & 3,1 & 2,1 & 3,5 & 3,0 & 4,6 & 2,9 & 4,2 & 2,7 & 3,9 & 3,7 \\
\hline Desvio & 1,0 & 1,2 & 0,8 & 1,1 & 0,9 & 0,7 & 1,0 & 1,4 & 1,6 & 1,3 & 1,6 & 1,3 \\
\hline
\end{tabular}

Rodrigues et al. (2004) utilizaram metodologia e base de dados similares às deste trabalho (os autores utilizaram 10 anos de dados, entre 1990 e 1999), obtendo resultados similares deste trabalho. Para o ponto SUL (próximo ao ponto de análise de Rodrigues et al., 2004) e o número médio de FF identificado por este estudo e pelos 
autores é igual para os meses de janeiro $(3,5)$ e fevereiro $(3,0)$. A única diferença para esta época do ano ocorreu no mês de março, quando os autores obtiveram média de 3,7 FF e este estudo 3,8 FF. Para os meses de inverno a mesma concordância entre os estudos foi observada. Para os meses de julho e agosto (setembro) este estudo encontrou média de 3,6 (3,5) FF enquanto que Rodrigues et al. (2004) encontraram $3,5(4,1) \mathrm{FF}$. Esta diferença pode estar associada aos diferentes comprimentos das séries.

Os resultados de quantidades de FF aqui obtidos também são similares aos descritos por Oliveira (1986), Lemos \& Calbete (1996) e da Silva \& Dias (2000) para o sul do Brasil, pois tais autores identificaram uma frequência frontal relativamente maior nos meses de maio a dezembro, diminuindo entre janeiro e abril. Mesmo assim, o maior número de FF, encontrado por esses autores nos meses de inverno e primavera, não difere muito dos períodos de verão e outono, como observado neste estudo.

Rodrigues et al. (2004) mostraram que cerca de três a quatro FF atingem o litoral de SC por mês, sendo a frequência maior durante a primavera. Em meses de inverno, um dia antes da passagem desta por SC, ela se encontra no RS, passa pelo estado no dia seguinte e chega ao litoral de SP e RJ um dia depois. O mesmo padrão de deslocamento foi obtido neste estudo para a FF média de inverno. Para as FF que não percorrem toda a extensão da PCSE, esses mesmos autores também mostraram que as FF avançam até o litoral de SP, dissipando-se mais rapidamente sobre o oceano dois dias depois da passarem por SC. Aqui foi obtido que a FF média que não percorre toda a extensão da PCSE tem tempo total de deslocamento de cerca de $30 \mathrm{~h}$ após passar pelo sul de SC, até a região norte do litoral de São Paulo.

Velocidade de propagação das FF médias, tempo percorrido e localização geográfica são mostradas na Figura 5.5. A localização geográfica das FF foi obtida da região de convergência dos ventos dos quadrantes nordeste (norte) e sudoeste (sul). Esta figura indica que a FF média de verão desloca-se mais rapidamente durante as primeiras $12 \mathrm{~h}(0 \mathrm{~h}$ indica o momento que as FF passam pelo Cabo de Santa Marta), com velocidade média de $55 \mathrm{~km} . \mathrm{h}^{-1}$ nas primeiras $6 \mathrm{~h}$ e $81 \mathrm{~km} \cdot \mathrm{h}^{-1}$ nas $6 \mathrm{~h}$ seguintes. De $12 \mathrm{~h}$ até $24 \mathrm{~h}$, a FF média de inverno permanece com praticamente a mesma velocidade de deslocamento (aproximadamente $45 \mathrm{~km} \cdot \mathrm{h}^{-1}$ ) enquanto que a FF média de verão sofre desaceleração, tendo a velocidade de propagação reduzida para aproximadamente $18 \mathrm{~km} \cdot \mathrm{h}^{-1}$. Desta maneira, $24 \mathrm{~h}$ após a passagem por Imbituba, ambas as FF médias de verão e inverno estão localizadas na divisa entre os estados de SP e RJ. Após 24 h, as FF médias que não percorrem toda a extensão da PCSE atingem seu deslocamento máximo. No verão, esta FF atinge São Sebastião enquanto que no inverno a distância percorrida é maior (até a fronteira dos estados 
de SP e RJ). Deste modo, a velocidade média de deslocamento das FF médias que não percorrem toda a extensão da PCSE, desde a passagem por Imbituba até o local de parada de propagação, é de $26 \mathrm{~km} \cdot \mathrm{h}^{-1}$ (verão) e $44 \mathrm{~km} \cdot \mathrm{h}^{-1}$ (inverno). Após as primeiras $24 \mathrm{~h}$, a FF média de verão tem a velocidade diminuída progressivamente, chegando ao extremo da PCSE após $42 \mathrm{~h}$, diferentemente das $36 \mathrm{~h}$ gastas pela FF média de inverno. Desta maneira a velocidade média de deslocamento é de $26 \mathrm{~km} \cdot \mathrm{h}^{-1}$ no verão e de inverno de $30 \mathrm{~km} \cdot \mathrm{h}^{-1}$ no inverno.

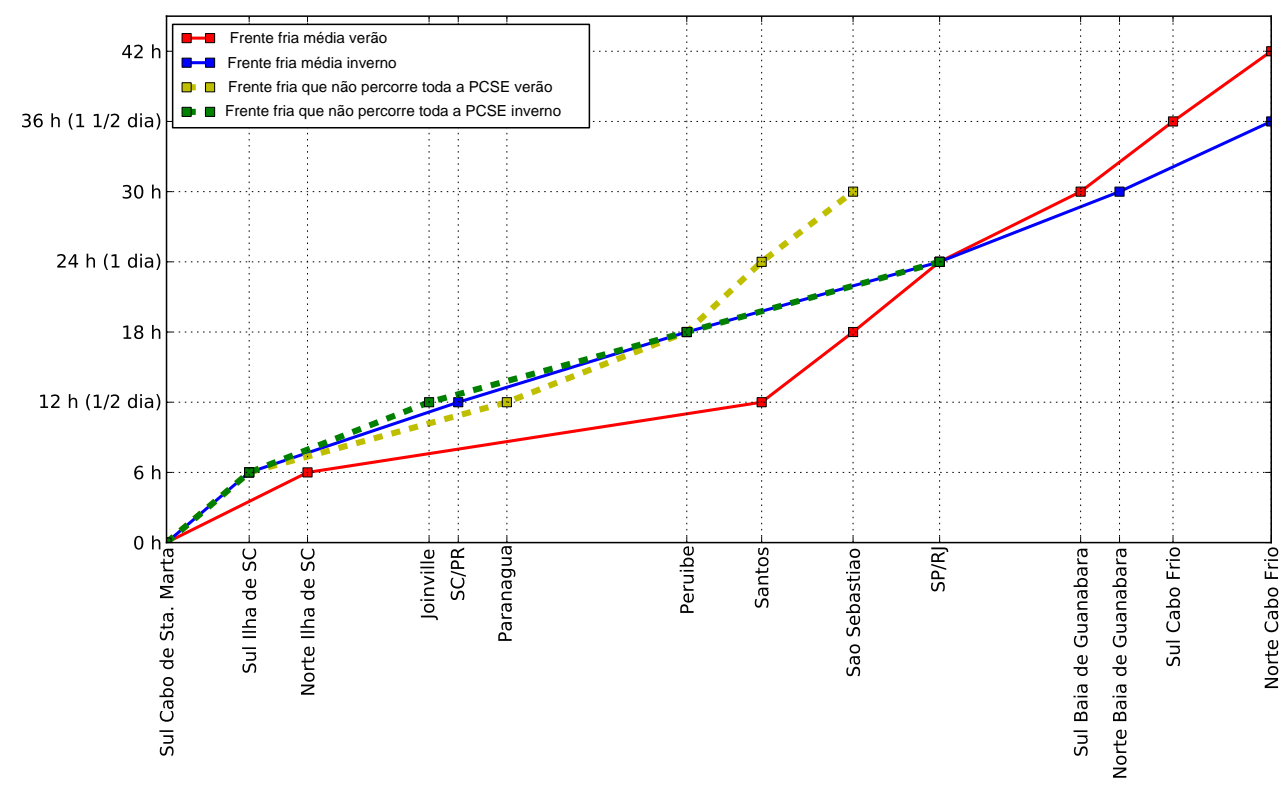

(a)

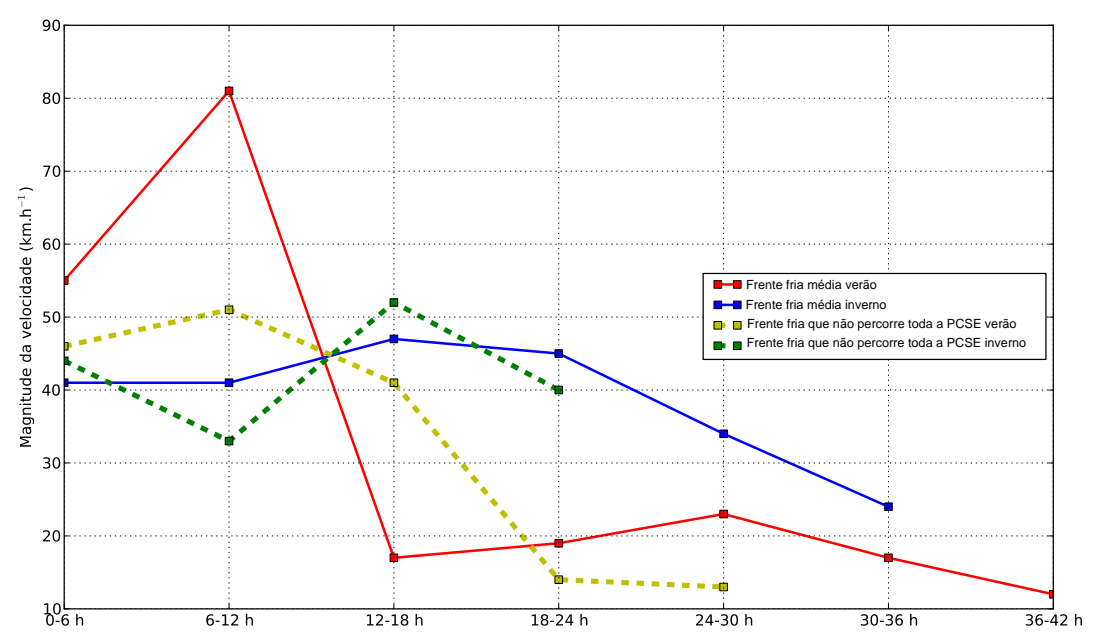

(b)

Figura 5.5: No painel (a) tempo de deslocamento (eixo das ordenadas) e localização geográfica (eixo das abscissas) das FF médias. Em (b) magnitude da velocidade de deslocamento (eixo das ordenadas) das FF médias em função do tempo de deslocamento (eixo das abcissas).

Stech \& Lorenzzetti (1992) e Coelho (2007) também construíram modelos de 
FF médias para a PCSE. O primeiro estudo apresenta um modelo conceitual para a passagem de FF no inverno com base em cartas sinóticas e imagens de satélite. Estes autores descrevem a FF conceitual com deslocamento típico de sudoeste para nordeste e velocidade aproximada de $20 \mathrm{~km} \cdot \mathrm{h}^{-1}$. Citam ainda que, no setor quente, a magnitude média dos ventos é de $5 \mathrm{~m} . \mathrm{s}^{-1}$; que a direção do vento muda de nordeste para noroeste na aproximação da frente e que, no setor frio, os ventos são mais intensos $\left(8 \mathrm{~m} . \mathrm{s}^{-1}\right)$ e provenientes da direção sudeste. Após $24 \mathrm{~h}$ da passagem da FF o sentido dos ventos é invertido para o original. As velocidades de propagação das FF médias obtidas aqui são relativamente diferentes daquelas apresentadas por Stech \& Lorenzzetti (1992). Contudo, o sentido de rotação dos ventos (nordeste para sudeste em sentido anti-horário) e a intensidade média dos ventos nos setores frio e quente são equivalentes. A FF média descrita por Coelho (2007) foi criada a partir de cartas sinóticas referentes a um período de 8 anos (1998-2005), sendo selecionadas $12 \mathrm{FF}$ que percorreram toda a extensão da PCSE. As seguintes características foram obtidas: direção de propagação de sudoeste para nordeste, velocidade média de propagação da FF no verão foi mais intensa que no inverno $(32,8$ $\mathrm{km} \cdot \mathrm{h}^{-1}$ para a primeira) e esta percorre toda a extensão da PCSE em cerca de 31,5 h. Comparativamente aos resultados obtidos por Coelho (2007), os resultados aqui obtidos são similares: a velocidade de propagação encontrada pelo autor foi de 23 $\mathrm{km} \cdot \mathrm{h}^{-1}$ e por este estudo $26 \mathrm{~km} \cdot \mathrm{h}^{-1}$. Coelho (2007) diz ainda que as FF de verão têm velocidade de propagação superior às FF de inverno e este fato foi comprovado aqui parcialmente (somente nas primeiras $12 \mathrm{~h}$ ) e condizentes com Andrade (2007). Coelho (2007) mostrou que, em média, as FF selecionadas percorreram toda a extensão da PCSE em aproximadamente 31,5 h. Neste estudo, em período de verão, este intervalo de tempo foi de $42 \mathrm{~h}$.

Como forma de avaliar o quanto as FF médias obtidas aqui são representativas calculamos o skill (Equação 3.4) em cada ponto da grade interpolada para o BDA (Figura 3.3), durante o período de passagem de cada uma das FF. Este cálculo foi repetido comparando-se as FF médias de verão e de inverno com todas as demais identificadas em cada estação e, então, para cada ponto da grade, foi calculada a média aritmética entre todos os valores de skill calculados. Esses cálculos foram realizados para as componentes zonal e meridional do vento (Figura 5.6). Para a componente zonal, o skill médio entre a FF média de verão e todas as demais (painel da esquerda em (a) na Figura 5.6 mostra que o valor mínimo é de 0,7 na porção sul da PCSE e máximo de 0,8 na parte norte. Estes valores conferem confiabilidade ao modelo de FF média de verão, em especial na porção norte da PCSE. Para o inverno (painel da direita em (a) na Figura 5.6), a mesma análise mostra que na porção sul da PCSE o skill médio é de 0,7 , enquanto que na porção norte repete 0,8. Assim, para a componente zonal do vento as FF que percorrem toda a extensão 
da PCSE são ligeiramente mais representativas para o período de inverno. Para a componente meridional do vento, que é aquela que é mais drasticamente alterada na passagem de FF pela PCSE, os valores de skill são superiores aos obtidos para a componente zonal. O skill médio entre a FF média de inverno e todas as demais (painel da esquerda em (b) na Figura 5.6) mostra valor mínimo de 0,9 na porção sul e máximo de 0,95 na porção norte. Para o inverno (painel da direita em (b) na Figura 5.6), a mesma análise mostra que na porção sul o skill médio é de 0,9 , enquanto que na porção norte é de 0,95. Os valores de skill mostram que as FF médias obtidas possuem boa correlação com todas as demais FF que passam pela PCSE. É possível concluir ainda que na porção sul da PCSE os ventos em períodos de passagem de $\mathrm{FF}$ variam mais entre os eventos, diferentemente da porção norte da PCSE.

Portanto, aqui utilizamos uma base de 30 anos de dados meteorológicos, que se mostrou eficiente na reprodução física de fenômenos de larga escala e de escala sinótica, sendo que para os meses de verão (inverno) foram analisadas 120 (266) FF que percorreram toda a extensão da PCSE e, a partir destas, foram estabelecidas duas FF médias sazonais. Estas FF médias sazonais apresentaram grande correlação com todas as demais identificadas, indicando que os modelos médios aqui estabelecidos têm representatividade perante toda a série de FF analisada. Para as FF que não percorreram toda a extensão da PCSE, as FF médias aqui modeladas provenientes da análise de 189 (55) FF no verão (inverno), são inéditas, não havendo outros trabalhos para comparação.

\subsection{Características das Oscilações Subinerciais do nível do mar}

Inicialmente, é conveniente mostrar que as simulações numéricas realizadas para a obtenção dos campos iniciais utilizados nos Experimentos 1A a 3B estabilizaramse em aproximadamente $190 \mathrm{~h}$, que é cerca de 30\% dos tempos obtidos por Rezende (2003), Coelho (2007) e Ruffato (2011) para experimentos similares na PCSE. Contudo, esses autores utilizaram campos de massa representativos de verão, que possuem variação lateral de densidade o que conduz ao ajuste baroclínico entre os campos de massa e corrente, diferentemente deste estudo.

Os campos correntes e nível do mar modelados nos cenários sintéticos com FF médias (experimentos 2A e 2B) foram similares aos obtidos por Stech \& Lorenzzetti (1992) e por Coelho (2007). Durante a passagem das FF a superfície livre do mar nas proximidades da costa teve variação máximos de $30 \mathrm{~cm}$, com decaimento em direção ao oceano adjacente. As correntes verticalmente integradas mudaram de 
direção em todos os compartimentos da PCSE em aproximadamente $72 \mathrm{~h}(24 \mathrm{~h}$ após as FF passarem pelo Cabo de Santa Marta). Após a passagem da FF houve estabelecimento de equilíbrio geostrófico resultante do rebaixamento da superfície livre do mar na região costeira, quando comparada à quebra da PCSE. A superfície livre do mar as correntes retornaram a valores comparáveis ao início das simulações após 216 h (168 h após as FF passarem pelo Cabo de Santa Marta).
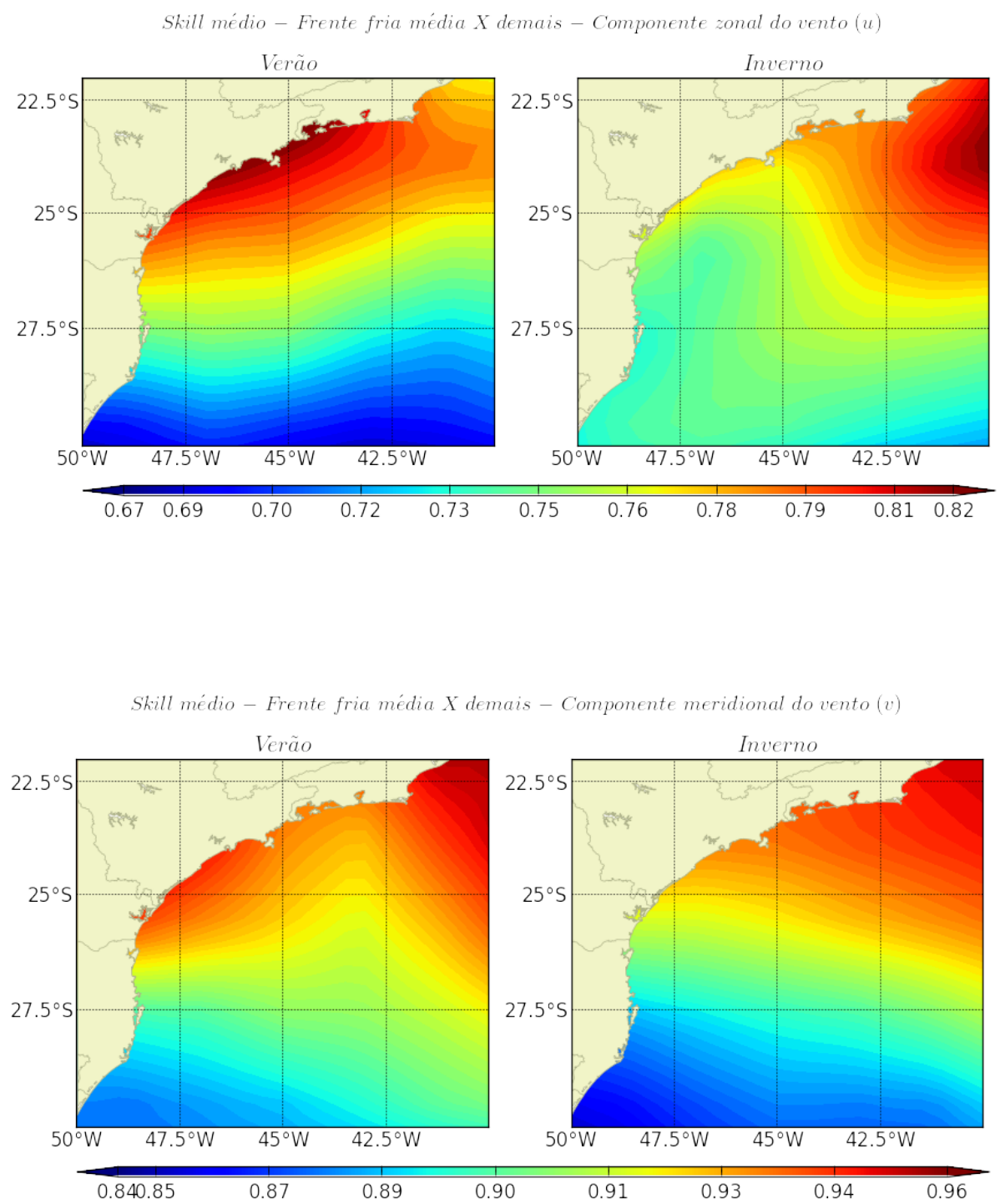

Figura 5.6: Nos painéis em superiores skill médio da componente zonal do vento, entre a FF média de verão (esquerda) e todas as demais identificadas e entre a FF média de inverno (direita) e todas as demais identificadas. Os painéis inferiores são similares aos superiores, contudo para a componente meridional do vento.

Os espectros de potência da elevação do nível do mar modelados para a PCSE 
indicaram, no verão, picos energéticos principalmente entre 3-5, 7-9 e 17-19 dias. No inverno, os períodos energéticos foram os centrados em 3, 4-5, 5-8,10-11 e 19-20 dias. Castro \& Lee (1995) encontraram, no inverno, energias centradas nos períodos de 4-4,4; 6-6,9 e 9,6-12 dias, similares aos deste estudo. Uaissone (2004) para todas as estações do ano, encontrou picos energéticos centrados em 5-7 e 16-21 dias, também concordante com este estudo. Filippo et al. (2012), ao longo do ano, encontrou picos energéticos nos períodos de 3,$5 ; 5,2 ; 5,7 ; 7,7 ; 10,4$; e 27,8 dias ao longo da costa leste sul-americana, novamente condizente com este estudo. França (2013), a partir de dados de modelo, destacou os períodos entre 5-11, 12-16 e 20-25 dias como sendo os mais energéticos nas séries analisadas, indo de encontro novamente com as frequências aqui obtidas.

Na sequência desta Seção são analisadas as principais características das OS modeladas na PCSE.

\subsubsection{Propagação}

A partir dos Experimentos 2A, 2B, 3A e 3B (forçados pelas FF médias obtidas neste estudo), as Figuras 5.7 a 5.10 mostram a variação subinercial da superfície livre do mar na costa. Estas figuras evidenciam a propagação das perturbações desde a região sul da PCSE até o norte, com amplitudes máximas próximas à Cananéia. As perturbações geradas na passagem da FF média de inverno ( Figura 5.8) possuem maiores amplitudes que as geradas em experimento de verão (Figura 5.7). Para os Experimentos com FF que não percorrem toda a extensão da PCSE (Figuras $5.9 \mathrm{e}$ 5.10), a perturbação gerada na porção sul da PCSE propaga-se em direção ao norte, também ganhando amplitude até a região de Cananéia aproximadamente, decaindo a partir daí.

Essas propagações para o norte, deixando a costa à esquerda, ficam mais evidentes na Figura 5.11 em todos os quatro cenários. As maiores alturas foram obtidas no cenário de FF média de inverno (Experimento 2B) e, as menores em FF que não percorreu toda a extensão da PCSE no inverno (Experimento 3B). Comparando as oscilações geradas pelas FF médias e FF médias que não percorreram toda a extensão da PCSE, as amplitudes destas últimas são cerca de $20 \mathrm{~cm}$ menores. 
$0.3 m$ г

Elevącão do nível do mar $(m)$ - Subinercial - Verão

Cabo Frio

$-0.3 m$ ᄂ

$0.3 m_{\text {г }}$

Rio de Janeiro

$-0.3 m$ ᄂ

$0.3 m$ г

Ilha Grande

$-0.3 m$ ᄂ

$0.3 m$

Ubatuba

$-0.3 m$ L

$0.3 \mathrm{~m}$ г

São Sebastião

$-0.3 m$ ᄂ

$0.3 m$ г

Santos

$-0.3 m$ ᄂ

$0.3 \mathrm{~m}\ulcorner$

Peruíbe

$-0.3 m$ ᄂ

$0.3 \mathrm{~m}$ г

Cananéia

$-0.3 m$ ᄂ

$0.3 \mathrm{~m}$ г

Paranaguá

$-0.3 m$ ᄂ

$0.3 \mathrm{~m}$ г

São Francisco

$$
\begin{gathered}
-0.3 m\llcorner \\
0.3 m \\
\text { Itajaí } \\
-0.3 m \text { ᄂ } \\
0.3 m \text { г }
\end{gathered}
$$

Florianópolis

$-0.3 m$ 느

$0.3 m_{\text {r }}$

Imbituba

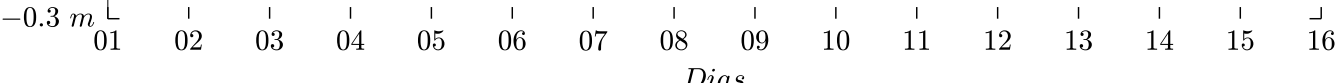

Figura 5.7: Elevação subinercial da superfície do mar modelada para passagem de frente fria média no verão (experimento $2 \mathrm{~A}$ ), de acordo com os locais descritos à esquerda dos gráficos. 


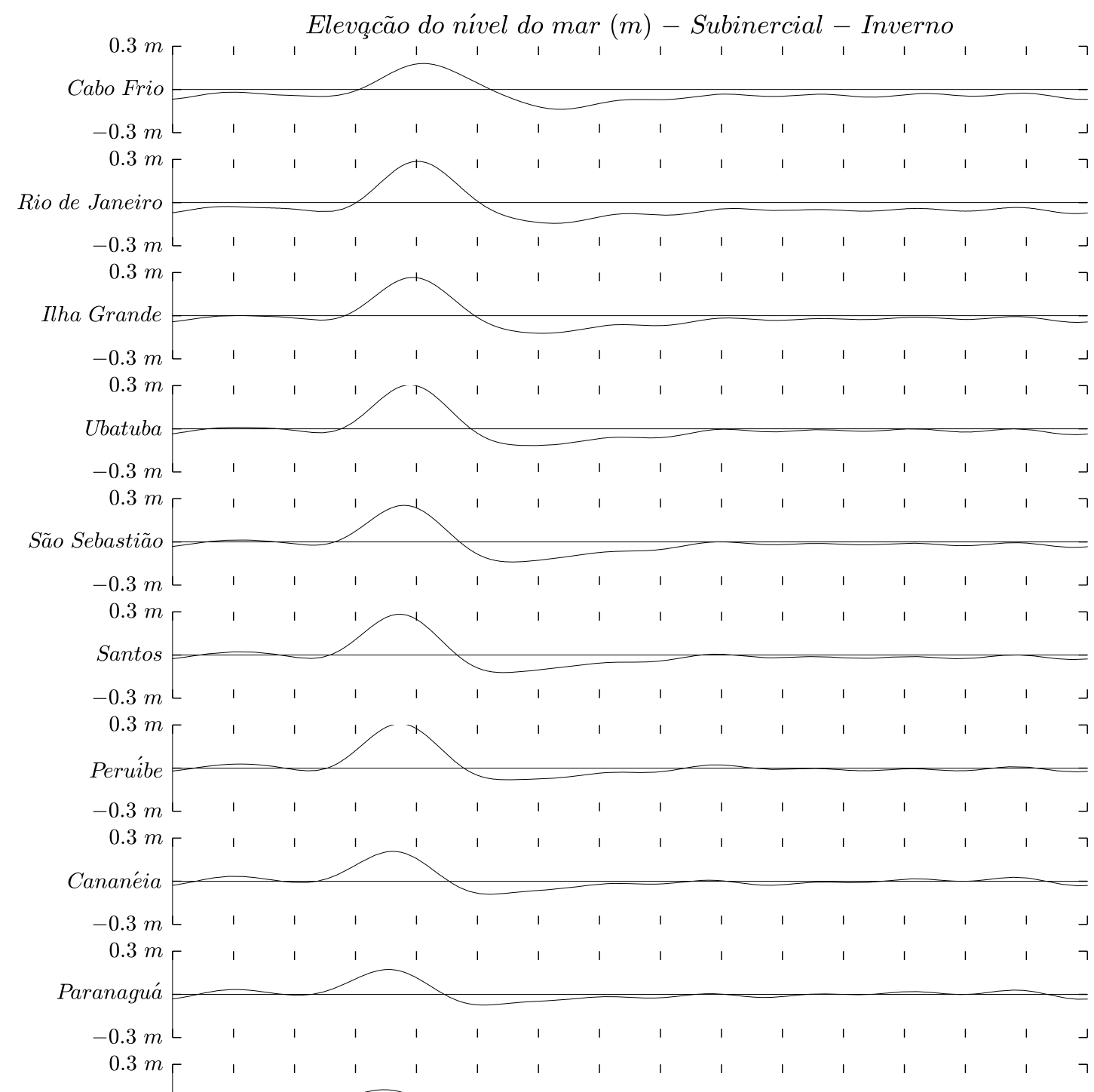

São Francisco

$$
\begin{gathered}
-0.3 m\llcorner \\
0.3 m \\
\text { Itajai } \\
-0.3 m\llcorner \\
0.3 m
\end{gathered}
$$

Florianópolis

$$
\begin{array}{r}
-0.3 m \\
0.3 m \\
\text { ᄂ }
\end{array}
$$

Imbituba

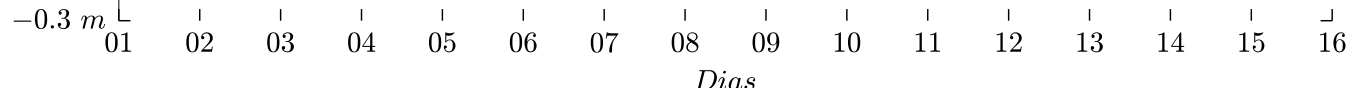

Figura 5.8: Elevação subinercial da superfície do mar modelada para passagem de fria fria média no inverno (experimento 2B), de acordo com os locais descritos à esquerda dos gráficos 


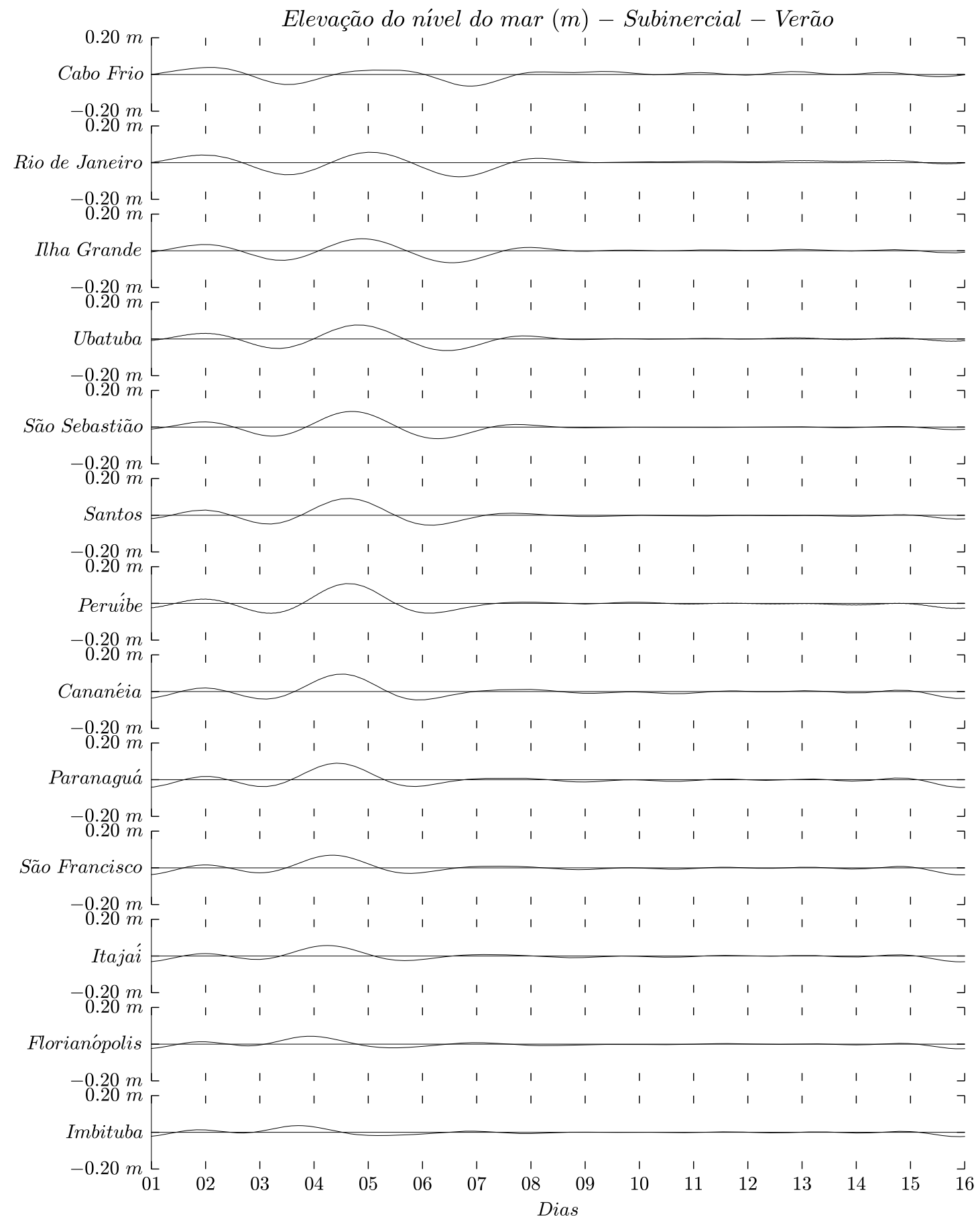

Figura 5.9: Elevação subinercial da superfície do mar modelada para passagem de frente fria média que não percorre toda a extensão da Plataforma Continental Sudeste no verão (experimento $3 \mathrm{~A}$ ), de acordo com os locais descritos à esquerda dos gráficos. 


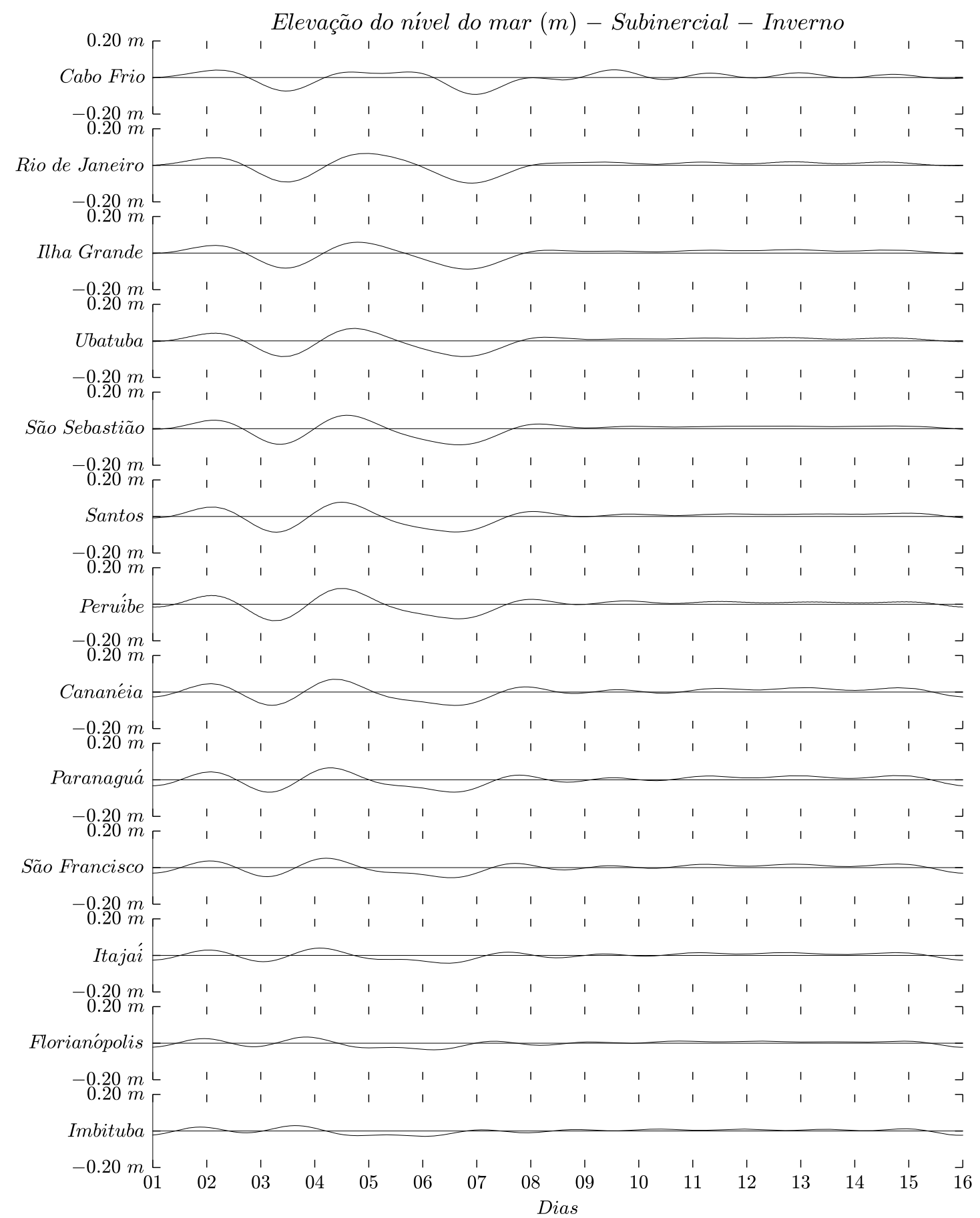

Figura 5.10: Elevação subinercial da superfície do mar para passagem de frente fria média que não percorre toda a extensão da Plataforma Continental Sudeste no inverno (experimento 3B), de acordo com os locais descritos à esquerda dos gráficos. 


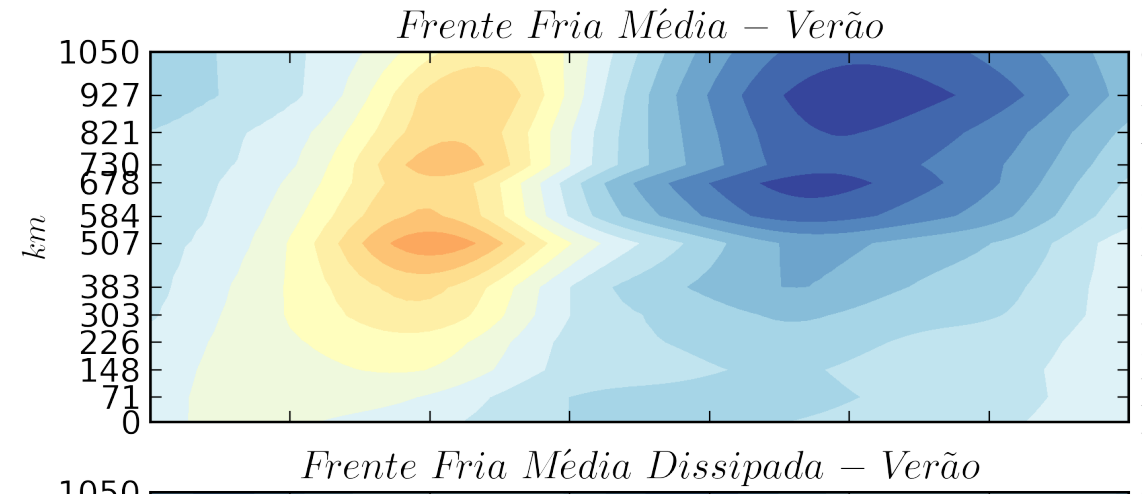

Cabo Frio

Rio de Janeiro

Ilha Grande

Sabatuba sebastião

Santos

Peruíbe

Cananéia

Paranaguá

São Francisco

Itajaí

Florianópolis

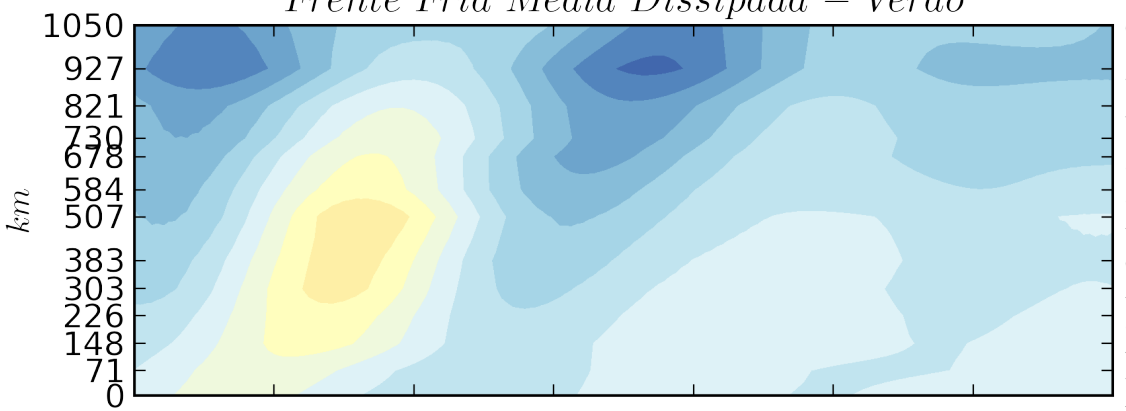

Cabo Frio

Rio de Janeiro

Ilha Grande

Ubat uba

Sao Sebastião

Santos

Peruíbe

Cananéia

São Francisco

Itajai

Florianópolis
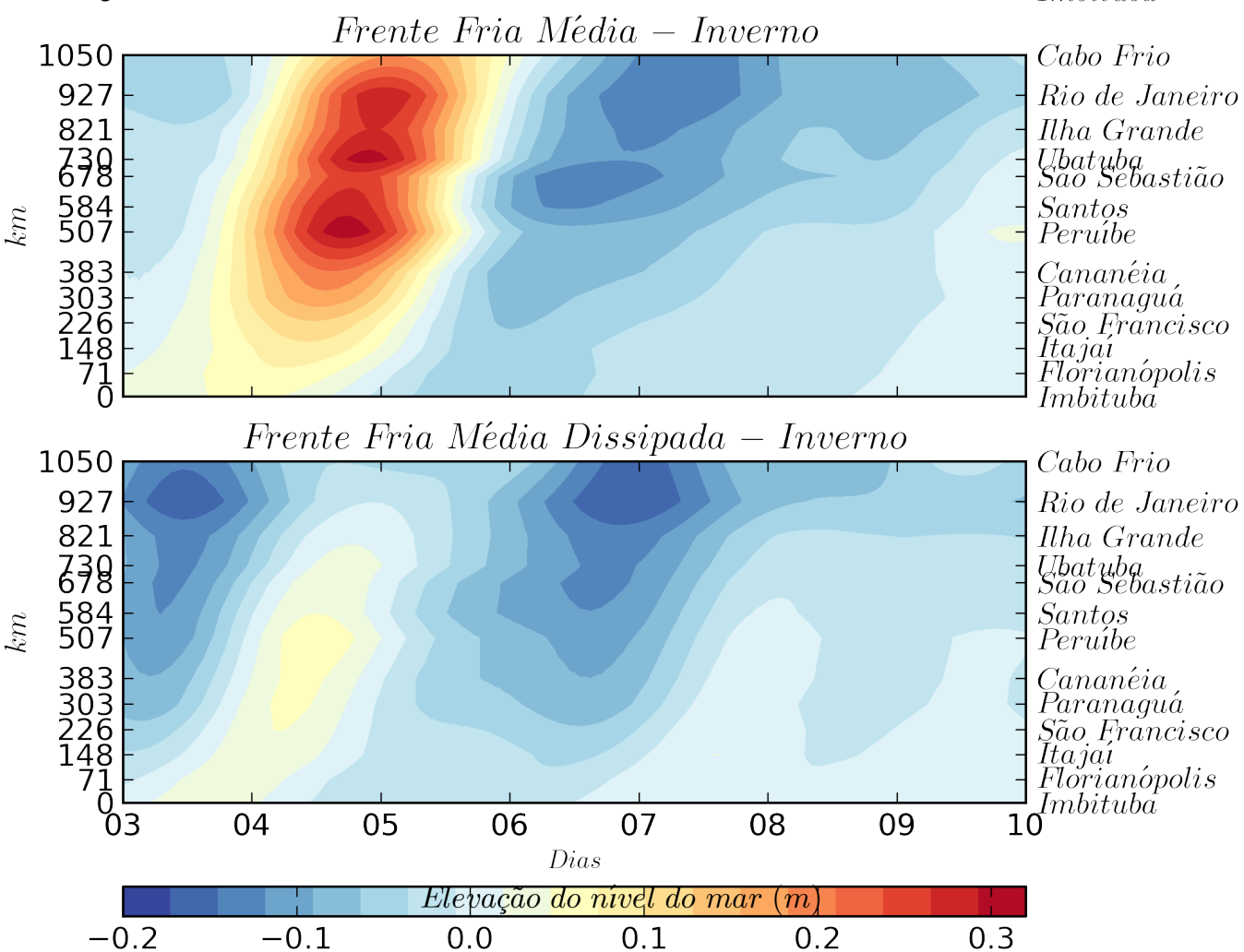

Figura 5.11: Isopletas de elevação do nível do mar (em m) nos locais descritos no eixo vertical à esquerda, ao longo dos dias de simulação (eixo horizontal) dos cenários de frente fria média e frente fria média que não percorre toda a extensão da Plataforma Continental Sudeste no verão (dois painéis superiores), e dos cenários de frente fria média e frente fria média que não percorre toda a Plataforma Continental Sudeste no inverno (dois painéis inferiores). 
A duração aproximada das oscilações, estimada usando a razão espaço/tempo na Figura 5.11 é de 50 h. No dia 5 de simulação das FF médias (Experimentos 2A e 2B), nota-se que o cavado da perturbação estava em Imbituba e a crista em Cabo Frio. Assim esta perturbação tem aproximadamente $2000 \mathrm{~km}$ de comprimento de onda e velocidade de deslocamento de aproximadamente $40 \mathrm{~km} / \mathrm{h}(11 \mathrm{~m} / \mathrm{s})$, valor similar ao obtido por França (2013) (12 m/s ao sul de $23^{\circ} \mathrm{S}$ e $4 \mathrm{~m} / \mathrm{s}$ ao norte deste ponto), Castro \& Lee (1995) (9 m/s para oscilações de 9,6-12 dias de período e 9-10 $\mathrm{m} / \mathrm{s}$ para oscilações entre 4,4-7 dias de período) e Filippo (2003) (10,9 m/s).

A amplificação das oscilações em direção norte é comprovada na Figura 5.12 . onde fica evidente, também, que as FF médias geram oscilações com maiores amplitudes que as FF que não percorrem toda a extensão da PCSE e que as oscilações de inverno têm maiores amplitudes que as de verão. As quatro simulações evidenciam que as oscilações ganham amplitude até a região centro-sul do litoral de SP, mantendo-se constante a partir daí. Em Cabo Frio ocorreu diminuição da altura das oscilações em todas as simulações.

Nos cenários com FF médias que não percorreram toda a extensão da PCSE (Experimentos 3A e 3B), mesmo na porção norte da PCSE onde os ventos não foram significativamente alterados, ocorreu a variação do nível do mar em forma de onda propagante. Estas últimas simulações indicam a influência de forçantes remotas na variação do nível do mar e correntes na porção norte da PCSE, eventos estes observados por diversos autores como Castro \& Lee (1995), Uaissone (2004), Rahy (2006), Menezes (2007), Campos et al. (2010), Costa (2010) e França (2013). Ou seja, alterações no campo de ventos na porção sul e central da PCSE podem gerar oscilações que se deslocam para a porção norte da PCSE, independente do sistema meteorológico.

A propagação das oscilações pode ser analisada através da análise da correlação entre o nível do mar em algum ponto no litoral da porção sul da PCSE e o restante do domínio modelado. Nas Figuras 5.13 e 5.14 são apresentadas as correlações entre o nível em São Francisco do Sul e o resto do domínio, para FF médias de verão e de inverno (Experimentos 2A e 2B), e para FF médias que não percorreram toda a extensão da PCSE para verão e inverno (Experimentos 3A e 3B). Os experimentos com FF médias (Experimentos 2A e 2B) apresentou valores superiores a 0,8, com diminuição em direção à quebra da PCSE, refletindo que a escala de correlação ao longo da costa é superior a centenas de quilômetros, e muito maior do que a escala de correlação perpendicular à costa. Nos experimentos com FF médias que não percorreram toda a extensão da PCSE (Experimentos 3A e 3B), no inverno houve maior correlação na porção norte da PCSE com o nível de São Francisco do Sul, comparado ao verão, em que as oscilações até o litoral norte de SP apresentaram correlações superiores a 0,7 . 


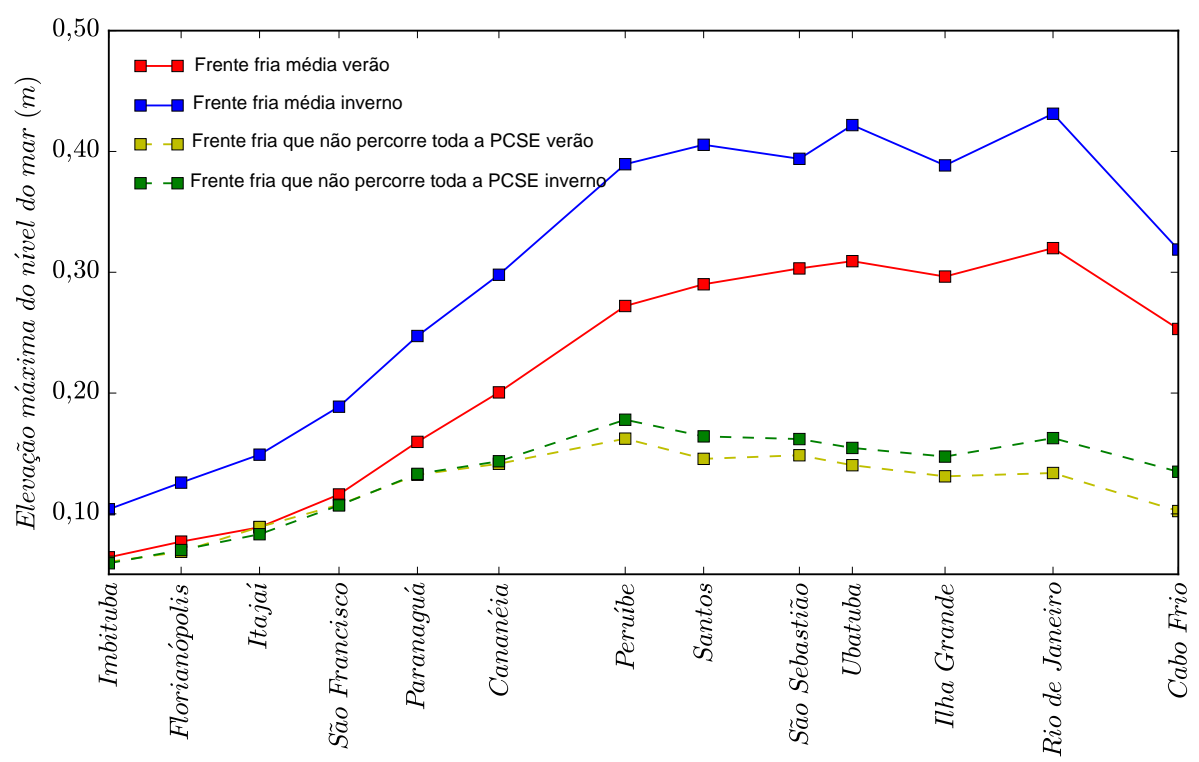

Figura 5.12: Elevação máxima do nível do mar subinercial na costa para cada experimento com frente frias médias (cores) em cada um dos locais destacados no eixo horizontal.

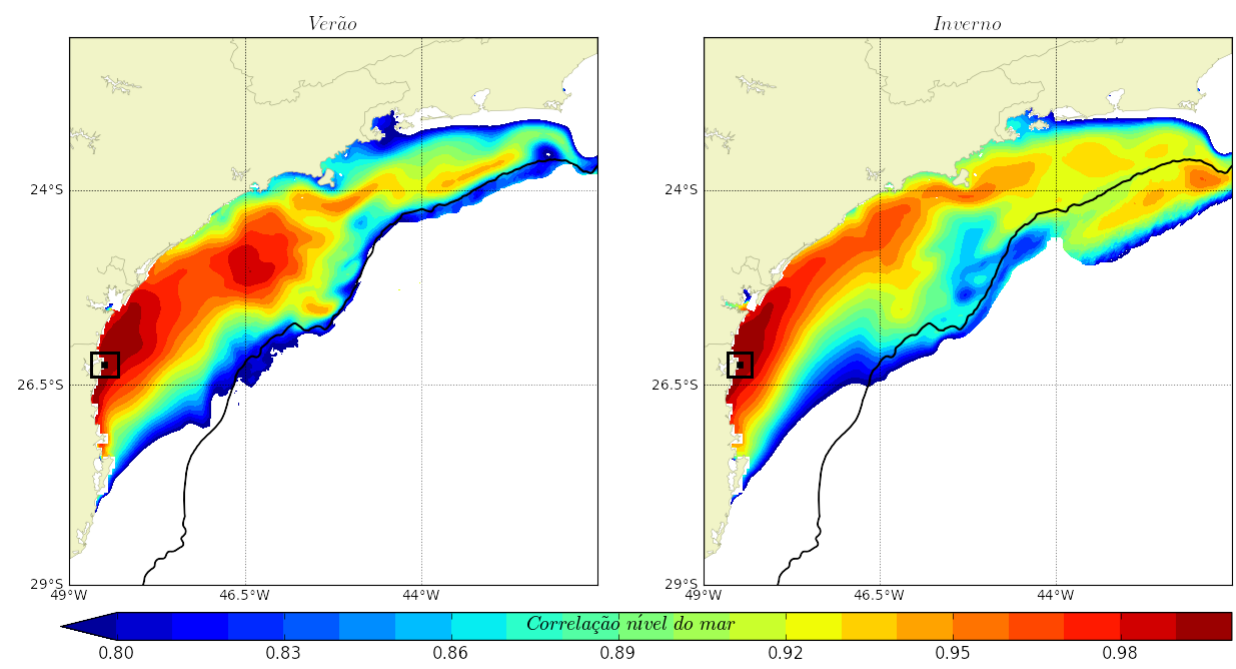

Figura 5.13: Correlação entre a variação do nível do mar em São Francisco do Sul (quadrado preto) com o restante do domínio, sendo mostrada somente valores superiores a 0,8. O painel da esquerda é para o cenário com frente fria média de verão e o da direita de inverno. A correlação apresentada é a máxima obtida em todos os lags positivos, com confiabilidade estatística de $95 \%$. 


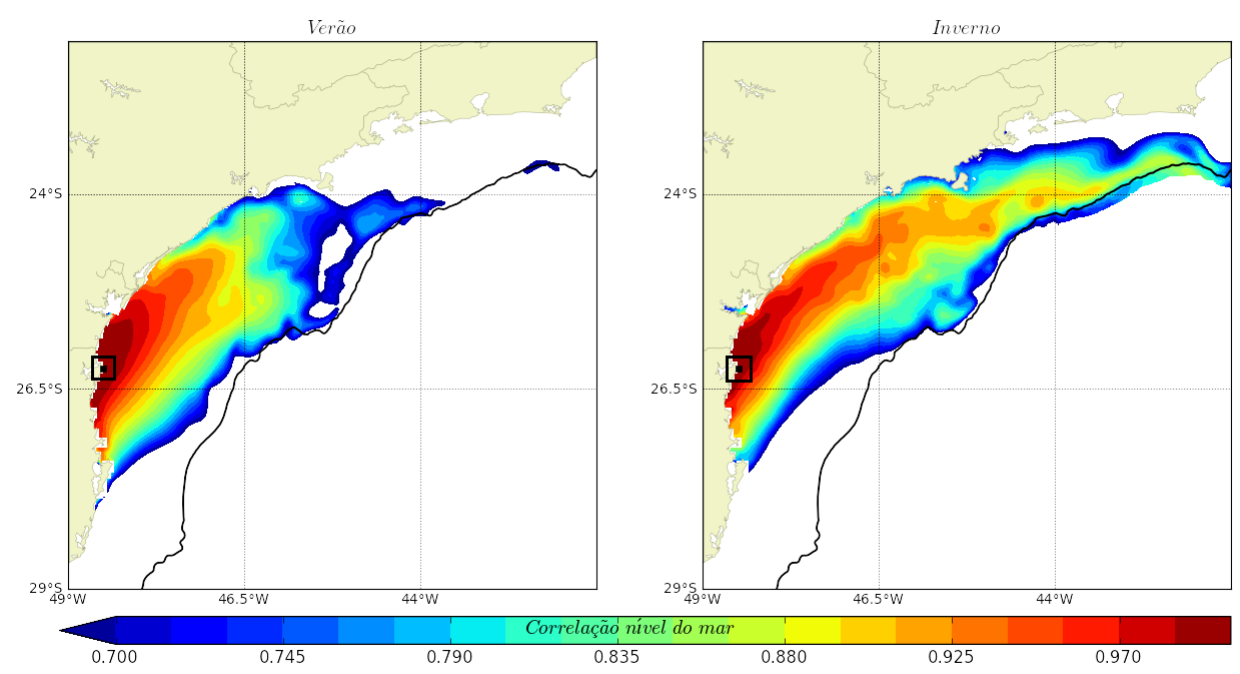

Figura 5.14: Correlação entre a variação do nível do mar em São Francisco do Sul (quadrado preto) com o restante do domínio, sendo mostrados somente valores superiores a 0,7 . O painel da esquerda é para o cenário com frente fria média que não percorre toda a extensão da PCSE no verão e o da direita no inverno. A correlação apresentada é a máxima obtida em todos os lags positivos, com confiabilidade estatística de $95 \%$.

\subsubsection{Confinamento}

A anisotropia horizontal das escalas de correlação da elevação da superfície do mar, comentadas na Seção 5.3.1 com relação às Figuras 5.13 e 5.14, sugerem que as OS ficam confinadas na PC. Também, a partir dos resultados obtidos nos Experimentos 2A, 2B, 3A e 3B nota-se que as elevações ou rebaixamentos da superfície do mar são máximas na costa, decaindo em amplitude para o largo, confirmando o confinamento dessas oscilações na PCSE (Figuras 5.15 a 5.18). Por exemplo, na Figura 5.15, no instante 96 h, as elevações do nível do mar são máximas na costa, decaindo em direção ao largo. Nessa mesma Figura 5.15, o rebaixamento do nível do mar, observado no instante 168 h é máximo na costa e, próximo à quebra da PCSE, todas as localidades apresentam praticamente o mesmo nível.

Para os experimentos com FFs médias que não percorrem toda a extensão da PCSE (Figuras 5.17 e 5.18), as amplitudes das elevações são reduzidas quando comparadas com os experimentos com FFs médias que percorrem toda a extensão da PCSE (Figuras 5.15 e 5.16); contudo os resultados evidenciam que na quebra da PCSE o nível do mar permanece praticamente inalterado em todas as radiais e em todos os instantes de tempo, tanto em período de verão quando de inverno. Enquanto o nível do mar oscila positiva e negativamente na costa, ao largo este 
permanece constante próximo ao valor de $0 \mathrm{~cm}$.

O confinamento nas proximidades da costa pode ser estimado também por meio do cálculo da média temporal da energia potencial por unidade de área horizontal em todo o domínio modelado, de acordo com a formulação proposta por Martinez \& Allen (2004):

$$
E P E=\frac{1}{2} \overline{\rho_{0} g \eta^{2}}
$$

onde, $\rho_{0}$ é a densidade padrão, $g$ é a aceleração da gravidade e $\eta$ é a variação do nível do mar. A barra horizontal sobre o produto indica média temporal.

Esta energia potencial média por unidade de área foi calculada para os cenários de ventos reais de verão e de inverno (Experimentos 1A e 1B, Figura 5.19). No verão essa energia potencial tem valor máximo médio na costa, de $2 \mathrm{~J} . \mathrm{m}^{-2}$ decaindo para o largo. No inverno o mesmo tipo de decaimento é observado; contudo a energia potencial acumulada na costa é relativamente maior, com valores máximos próximos a $5 \mathrm{~J} . \mathrm{m}^{-2}$. Estes valores são similares aos obtidos por Martinez \& Allen (2004) para experimento com forçantes remotas no Golfo da Califórnia. A Figura 5.19 mostra que as maiores energias estão centradas na porção do litoral e ao norte de Paranaguá. A amplificação para o norte, também obtida nos experimentos com FF médias (Figura 5.12) pode ser notada também na Figura 5.11. Este confinamento das perturbações foi observado por Dottori \& Castro (2009) ao analisarem dados correntográficos coletados nas partes interna e média e nas proximidades da quebra da PCSE. França (2013) obteve o mesmo padrão de confinamento nas séries de modelagem analisadas, entretanto o confinamento foi mais costeiro, pois na isóbata de $100 \mathrm{~m}$ poucas perturbações foram verificadas. 

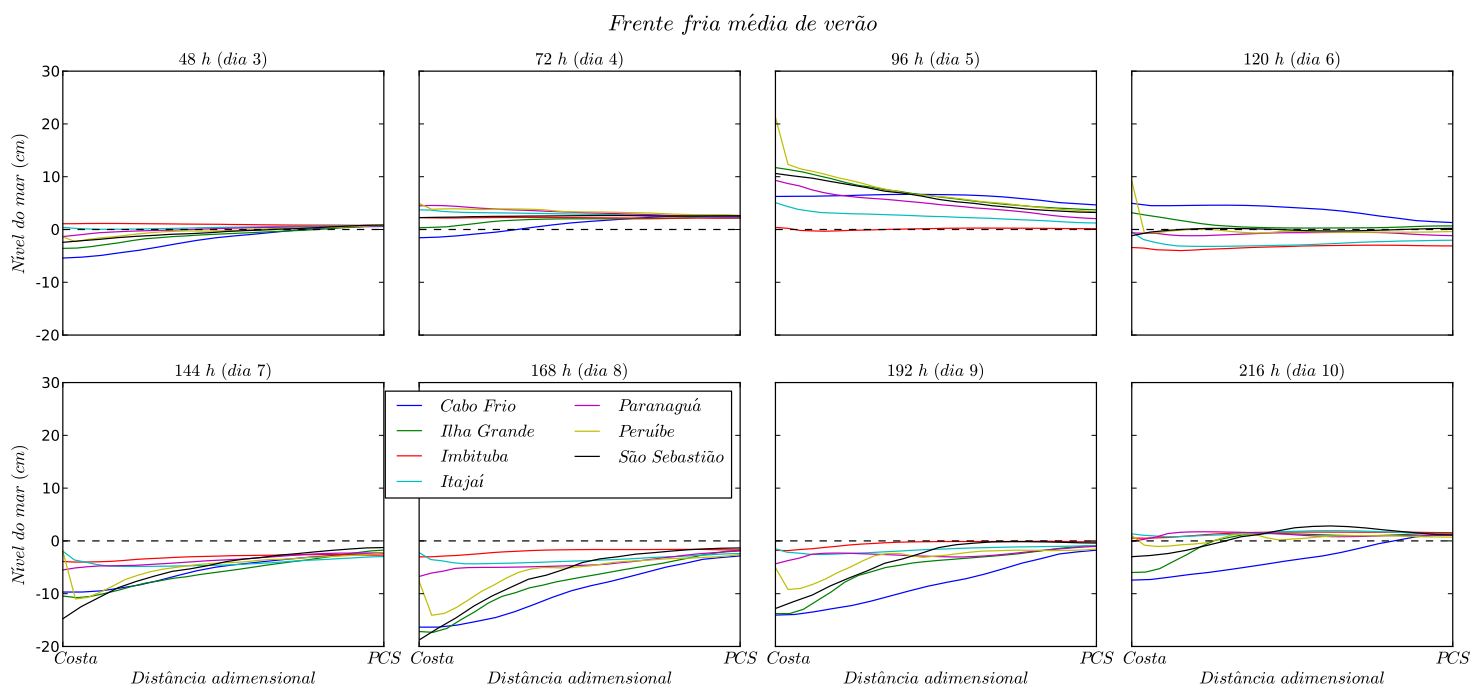

Figura 5.15: Elevação subinercial da superfície do mar desde a costa (esquerda nos painéis) até a quebra da PCSE (direita nos painéis) para passagem de FF média no verão (Experimento $2 \mathrm{~A}$ ), para os instantes descritos nos títulos dos painéis, e as radiais de acordo com a Figura 3.6 .

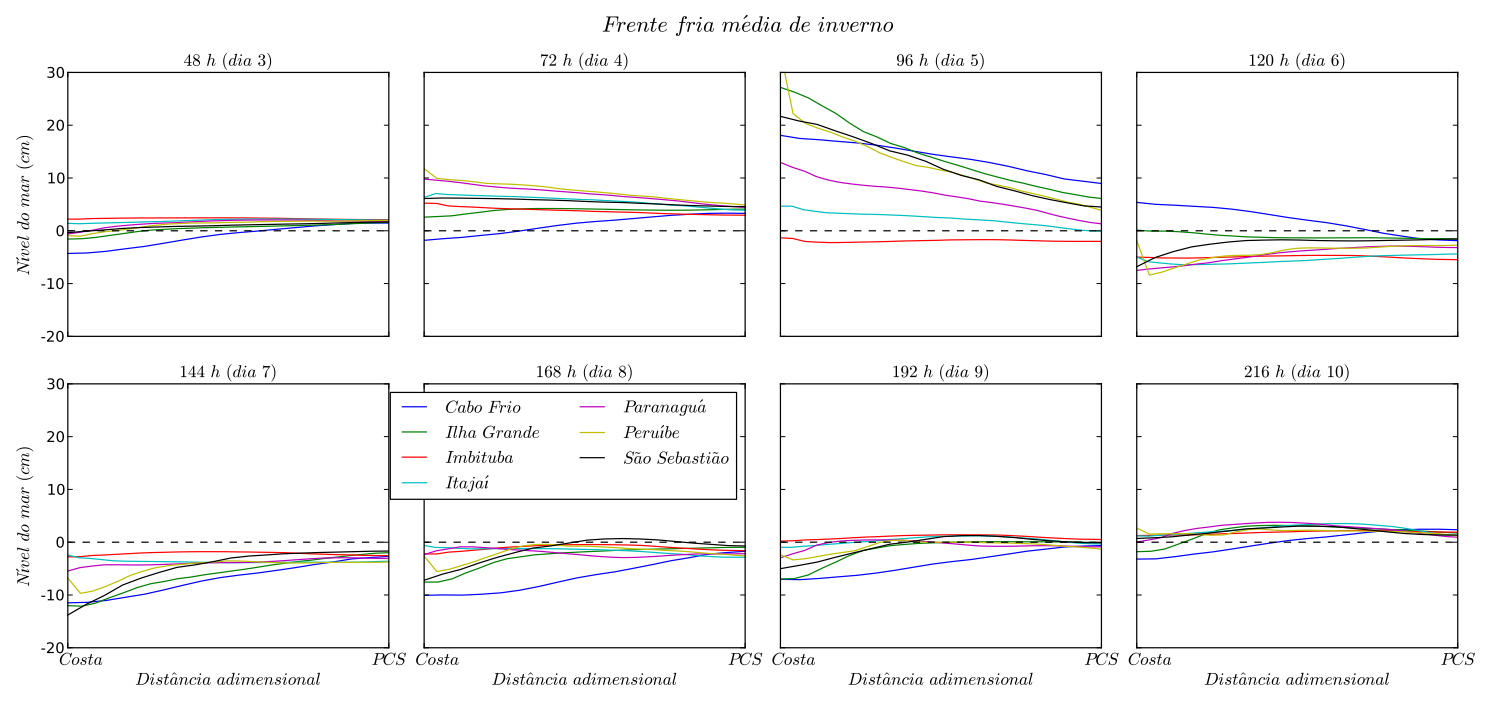

Figura 5.16: Elevação subinercial da superfície do mar desde a costa (esquerda nos painéis) até a quebra da PCSE (direita nos painéis) para passagem de FF média no inverno (Experimento 2B), para os instantes descritos nos títulos dos painéis, e as radiais de acordo com a Figura 3.6 . 


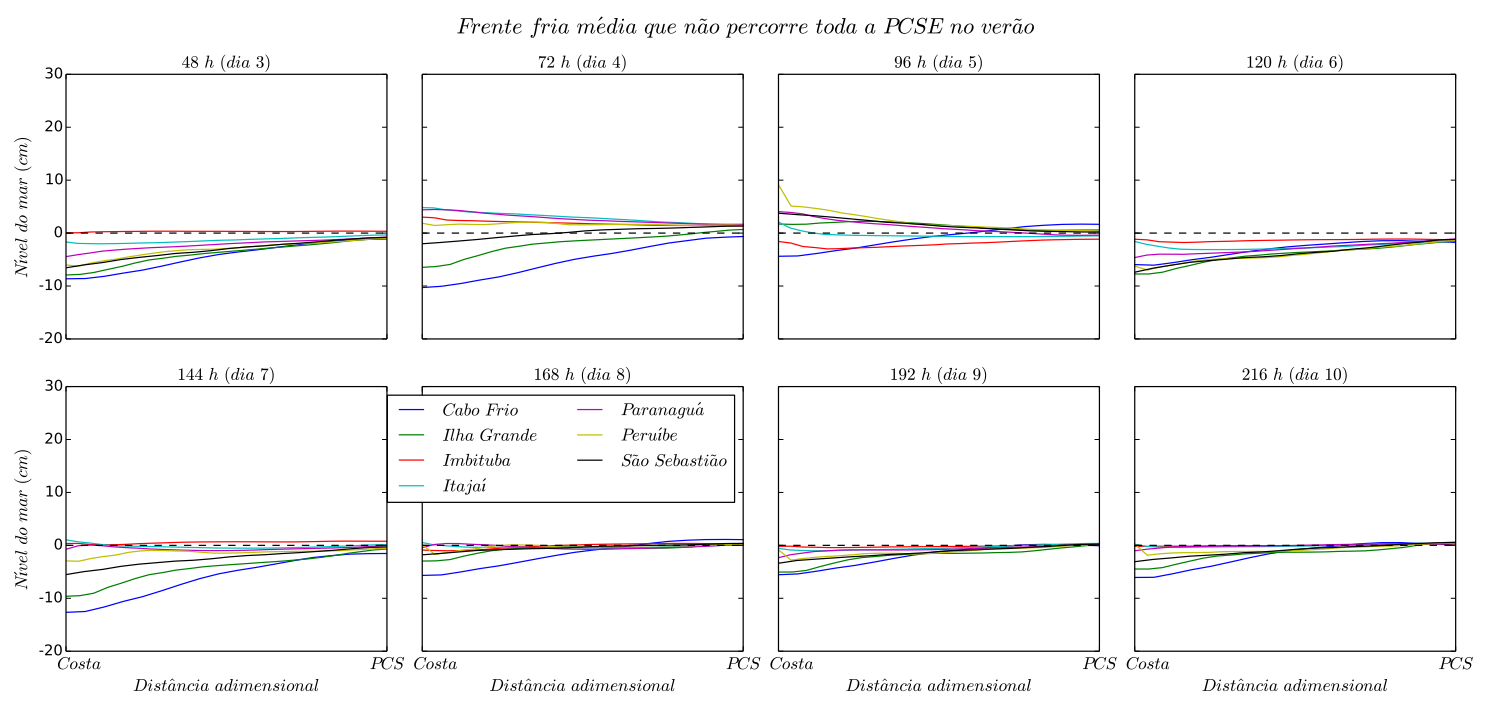

Figura 5.17: Elevação subinercial da superfície do mar desde a costa (esquerda nos painéis) até a quebra da PCSE (direita nos painéis) para passagem de FF média que não percorre toda a extensão da PCSE no verão (Experimento 3A), para os instantes descritos nos títulos dos painéis, e as radiais de acordo com a Figura 3.6.
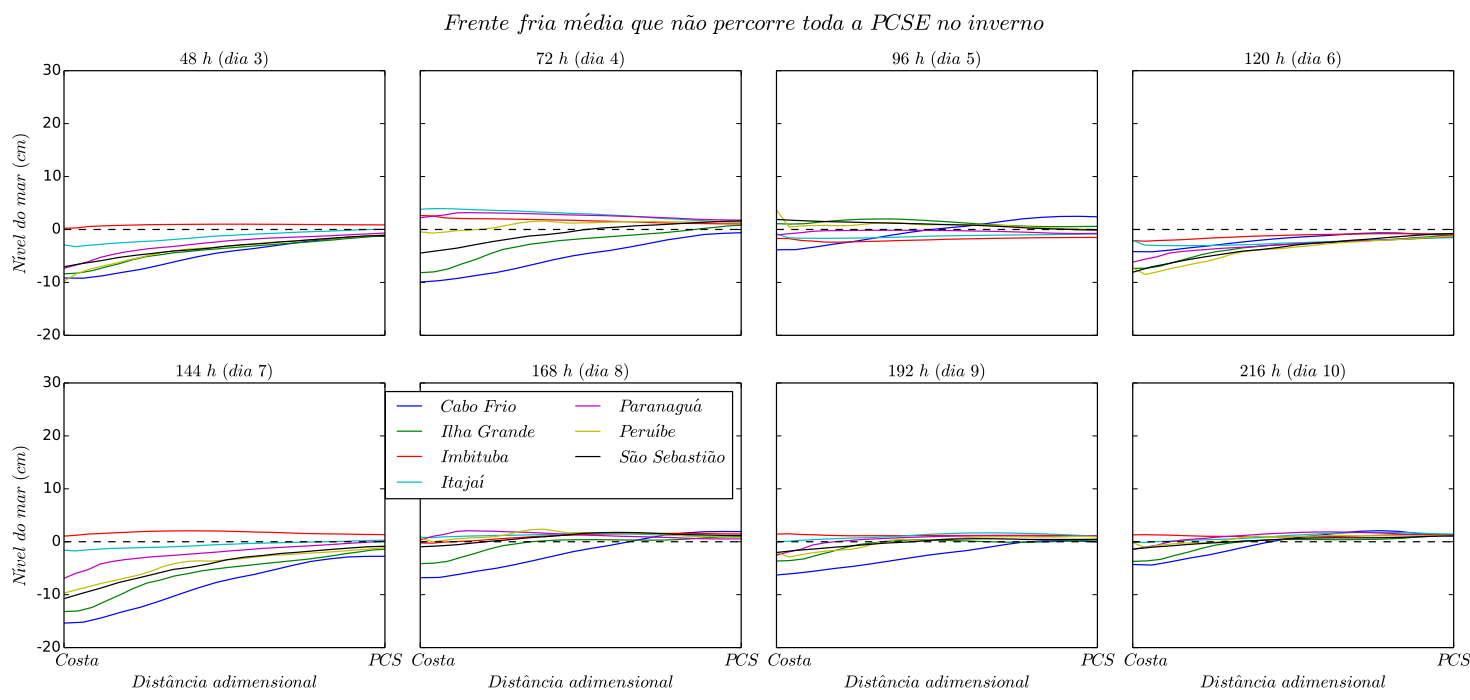

Figura 5.18: Elevação subinercial da superfície do mar desde a costa (esquerda nos painéis) até a quebra da PCSE (direita nos painéis) para passagem de FF média que não percorre toda a extensão da PCSE no inverno (Experimento 3B), para os instantes descritos nos títulos dos painéis, e as radiais de acordo com a Figura 3.6. 


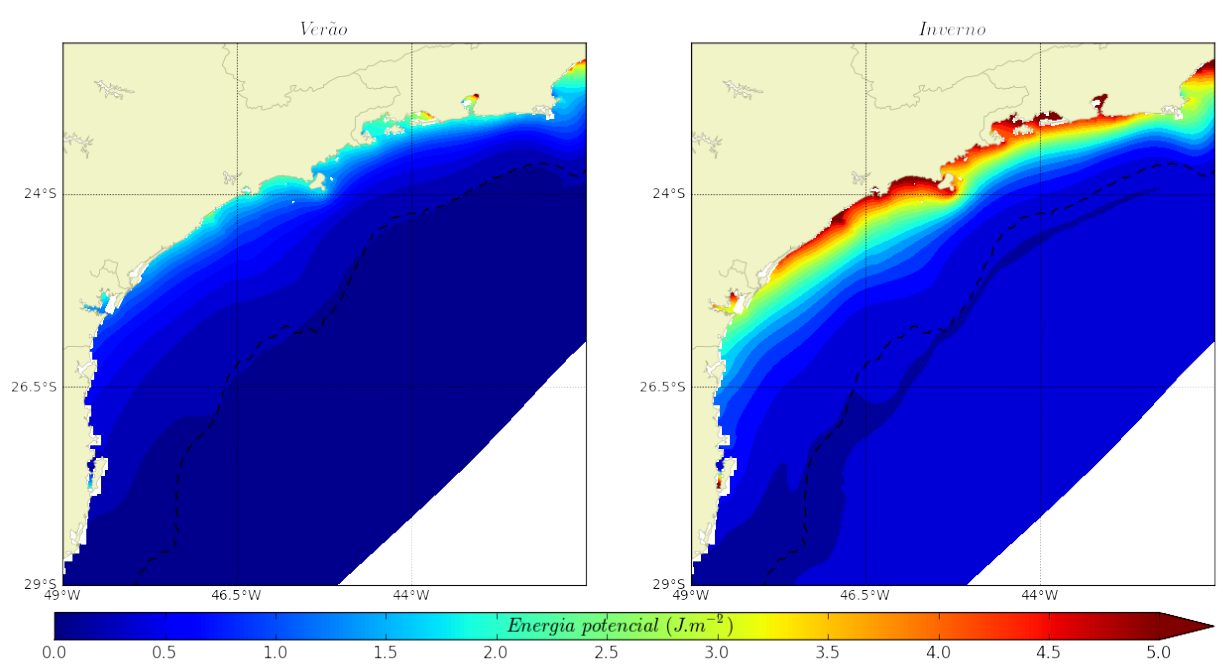

Figura 5.19: Média temporal da energia potencial por unidade de área horizontal $\left(J \cdot m^{-2}\right)$ para os cenários de ventos reais de verão (esquerda, Experimento 1A) e de inverno (direita, Experimento 1B).

\subsubsection{Resposta ao vento local e ao vento remoto}

Ao analisar a propagação das perturbações geradas nos experimentos com FF médias que não percorrem toda a extensão da PCSE (3A e 3B, Figuras 4.39 e 4.40 observamos que na porção norte da PCSE, onde os ventos não são alterados significativamente ao longo da simulação, o nível do mar e as correntes verticalmente integradas são alteradas. A análise de propagação indicou que alterações no campo de ventos na porção sul e central da PCSE podem gerar oscilações que se deslocam para a porção norte da PCSE (Figuras 4.26 e 4.28). Ou seja, na porção norte da PCSE ventos remotos (ventos na porção sul da PCSE) podem forçar alterações do nível do mar local. É conveniente, então, analisar qual a correlação entre o vento local e as variações subinerciais no nível do mar. As Figuras 5.20 e 5.21 mostram as correlações entre a variação subinercial do nível do mar na costa e as componentes do vento perpendicular e paralela à costa para os experimentos com ventos reais no verão e no inverno (1A e 1B). 


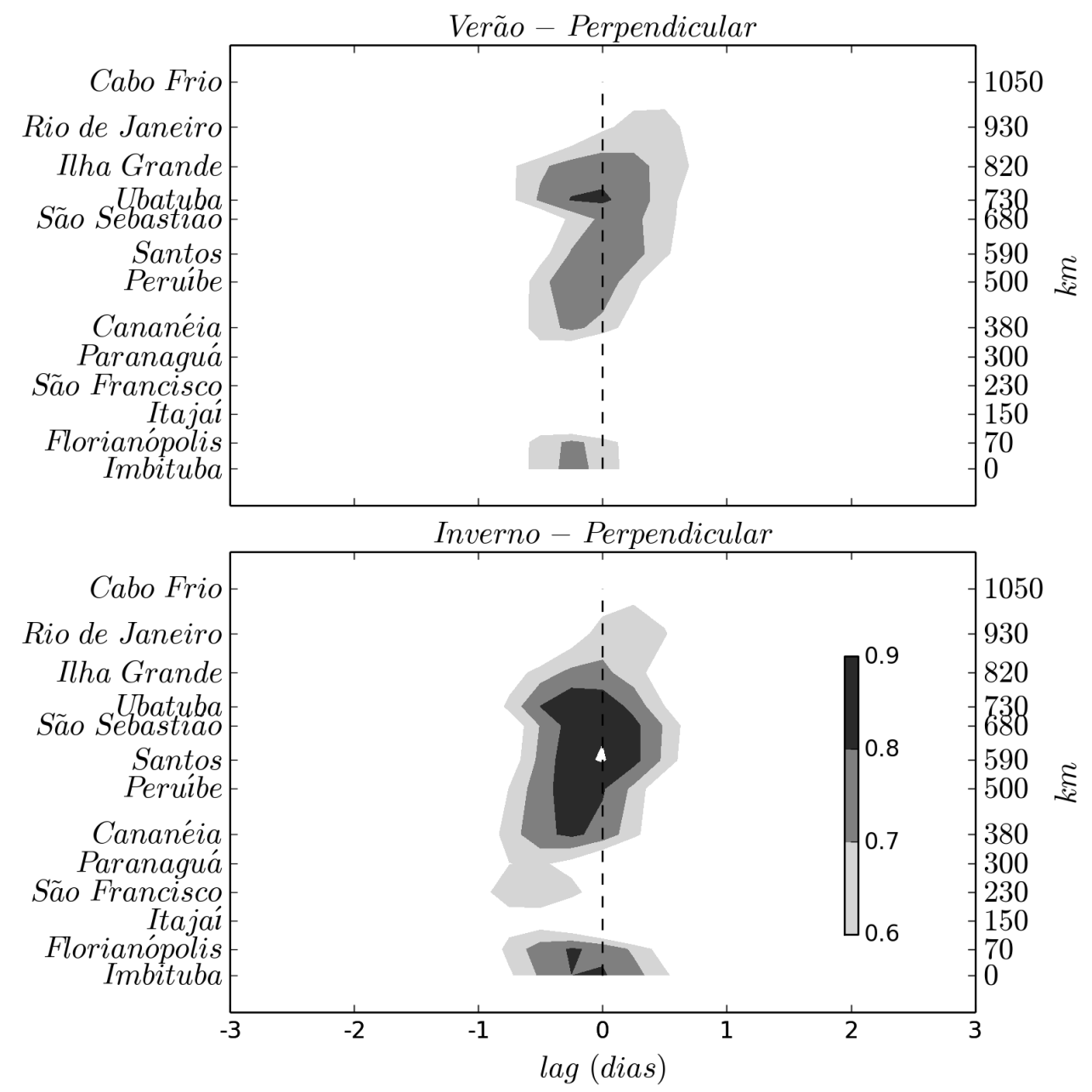

Figura 5.20: Correlação entre a variação subinercial do nível do mar na costa e a componente do vento perpendicular à costa nos locais listados no eixo vertical. O eixo horizontal representa a defasagem (lags) calculados. O painel superior é para o cenário de ventos reais no verão (experimento 1A) e o inferior de ventos reais no inverno (experimento 1B). É mostrada somente correlação mínima com confiabilidade estatística de $95 \%$, acima de 0,7 .

As correlações entre a variação subinercial do nível do mar e a componente do vento local perpendicular à linha de costa são superiores a 0,7 na região entre Cananéia e Ubatuba, tanto no verão quanto no inverno. Estas correlações foram obtidas com defasagem variando entre $-0,6$ dias (14 h - liderança do vento sobre o nível do mar) e 0,3 dias (7,2 h - liderança do nível do mar sobre os ventos). Somente no verão foram observadas correlações acima de 0,7 na região entre Imbituba e Florianópolis. Já as correlações entre a variação subinercial do nível do mar e a componente do vento local paralelo à linha de costa são superiores a 0,7 na região entre Florianópolis e Paranaguá, somente no inverno, com defasagem variando entre -0,2 e 0,2 dias (4,8 h). Estes resultados são similares aos de Castro \& Lee (1995), 
que obtiveram as maiores correlações das OS da superfície livre do mar com o vento local na região de Cananéia. Neste local, Costa (2010) também obteve as maiores correlações entre a variação do nível do mar e o vento perpendicular à costa. Oliveira et al. (2007) não encontraram correlação significativa entre o vento local e as oscilações da superfície livre do mar em Paranaguá, o mesmo descrito por Uaissone (2004) e Menezes (2007) para a costa do RJ. Estes autores que não encontraram correlação significativa entre oscilações do nível do mar e o vento local sugeriram possíveis influências de ventos remotos sobre a região estudada.

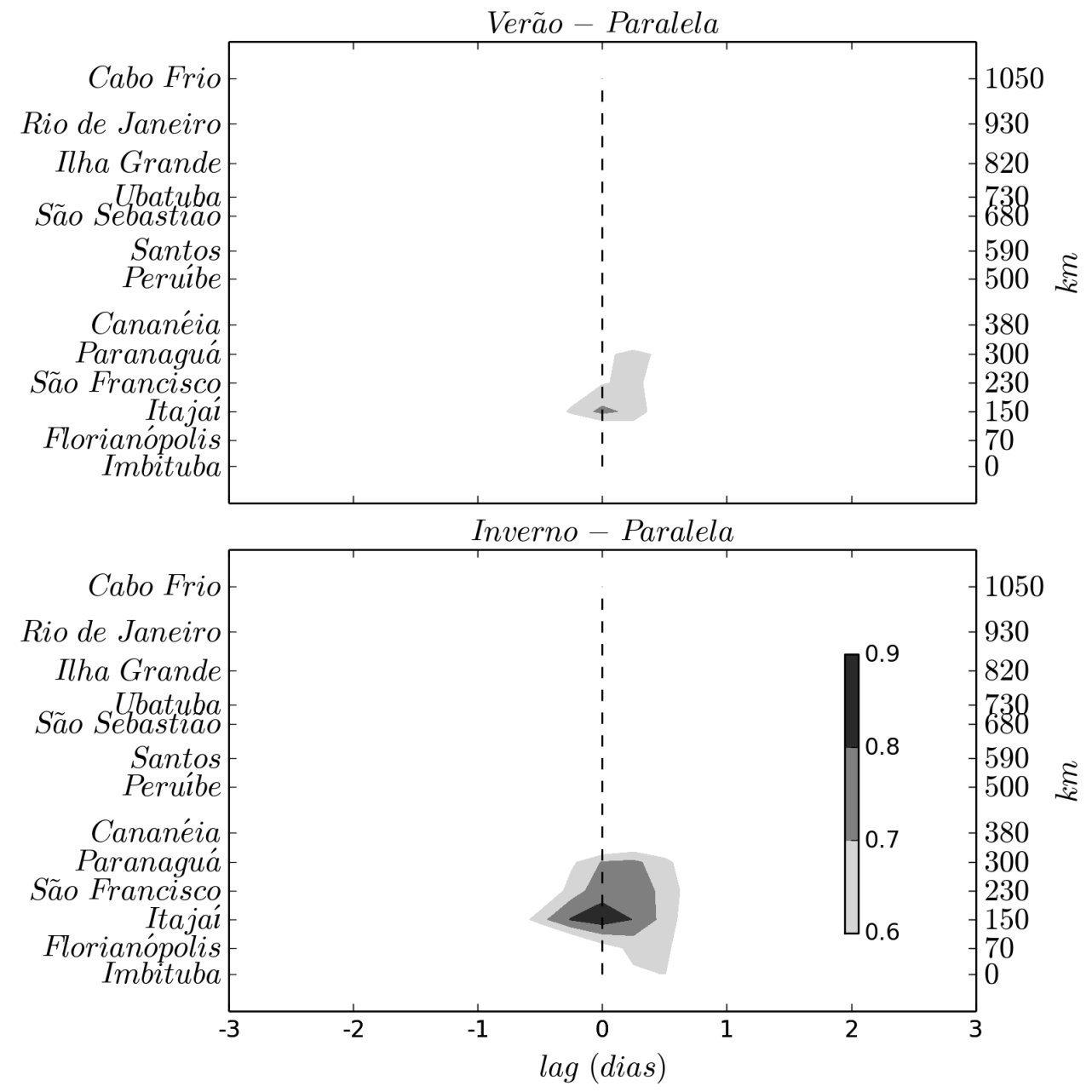

Figura 5.21: Correlação entre a variação subinercial do nível do mar na costa e a componente do vento paralela à costa nos locais listados no eixo vertical. O eixo horizontal representa a defasagem (lags) calculados. O painel superior é para o cenário de ventos reais no verão (experimento 1A) e o inferior de ventos reais no inverno (experimento 1B). É mostrada somente correlação mínima com confiabilidade estatística de $95 \%$ acima de 0,7 .

Nas Figuras 5.22 a 5.25 são apresentadas as correlações entre a variação da 
superfície livre do mar e as componente do vento ao longo da costa da PCSE, considerando-se os experimentos com ventos reais de verão e inverno (experimentos $1 \mathrm{~A}$ e 1B). Tanto no verão quanto no inverno todos os locais tiveram melhor correlação da oscilação da superfície livre do mar com os ventos paralelos à costa da região entre Imbituba e São Francisco. No verão, na região ao sul de Florianópolis não foram obtidas correlações superiores a 0,6 entre as oscilação do nível do mar e a componente do vento paralela à costa de nenhum local da PCSE. Como já mostrado anteriormente, no inverno a variação do nível do mar subinercial desta região possui alta correlação com a componente paralela à costa do vento local. Ao longo da costa da PCSE as correlações das oscilações da superfície livre do mar com a componente do vento perpendicular à costa foram maiores com a região entre Cananéia e Ubatuba, especialmente no inverno.

Estes resultados estão condizentes com os obtidos por Castro \& Lee (1995). Estes autores citam que as OS são melhor correlacionado com ventos de regiões localizadas entre 100 a $500 \mathrm{~km}$ ao sul e com defasagem de 0,5 a 1 dia. Ainda, eles citam que as porções central e norte da PCSE possuem OS do nível do mar melhor correlacionadas com ventos localizados ao sul, destacando a região entre São Francisco e Cananéia como sendo a região de máxima correlação. Além disso, estes resultados também corroboram as indicações de Campos et al. (2010) para Santos e de Uaissone (2004) e Menezes (2007) para a costa do RJ, sobre a importância dos ventos remotos para as OS do nível do mar. Oliveira et al. (2007) e Costa (2010) indicaram que o nível do mar em Cananéia poderia ser melhor correlacionado com a componente do vento paralela à linha de costa de alguma região ao sul e aqui é mostrado que a melhor correlação foi obtida com a região de Itajaí. 


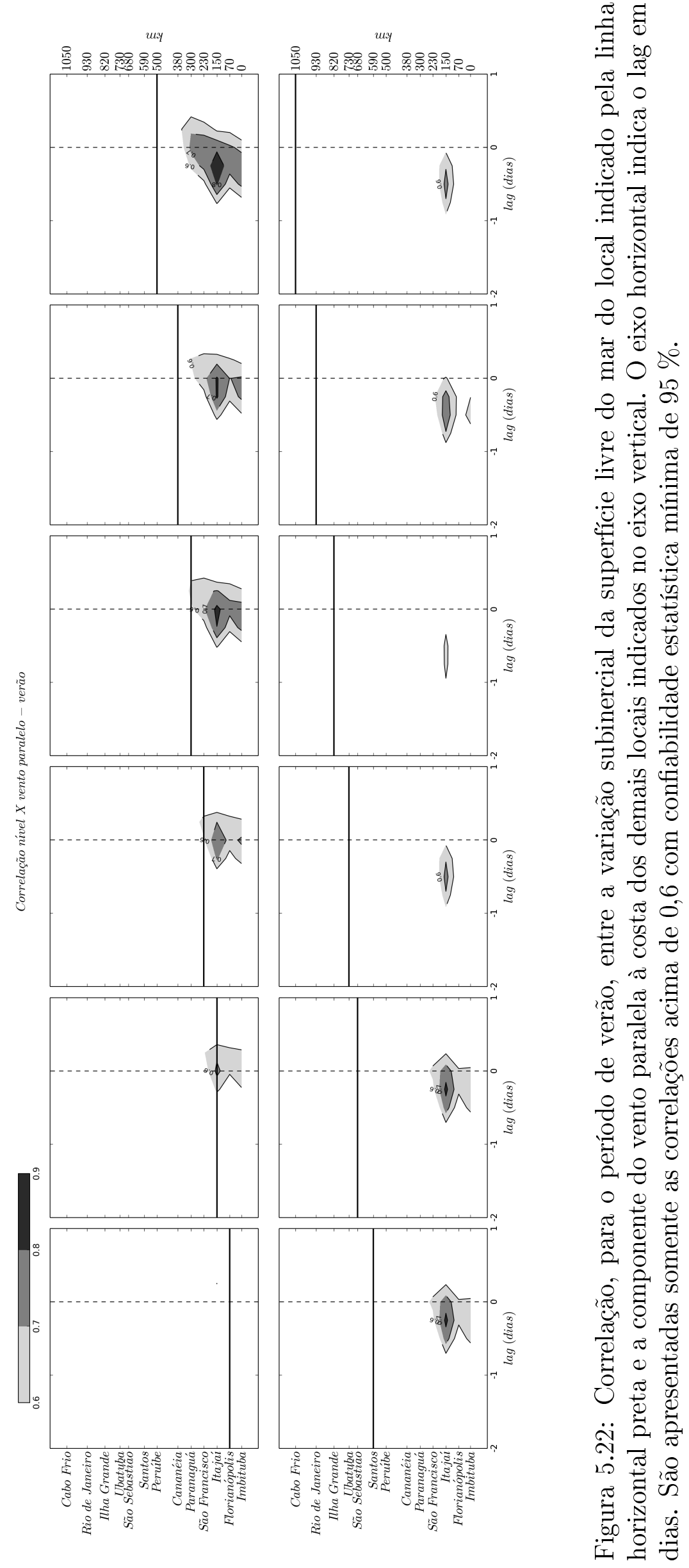




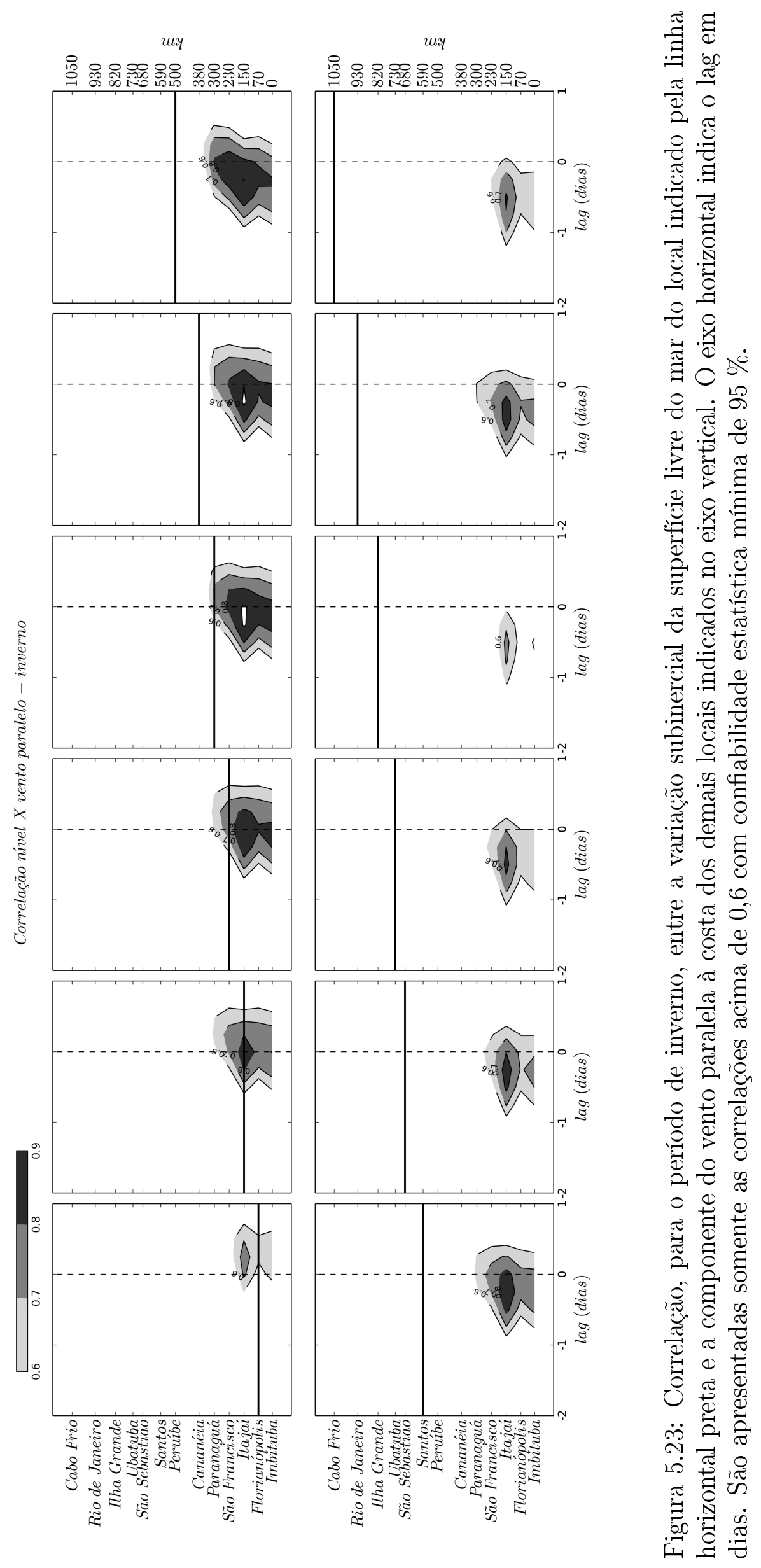




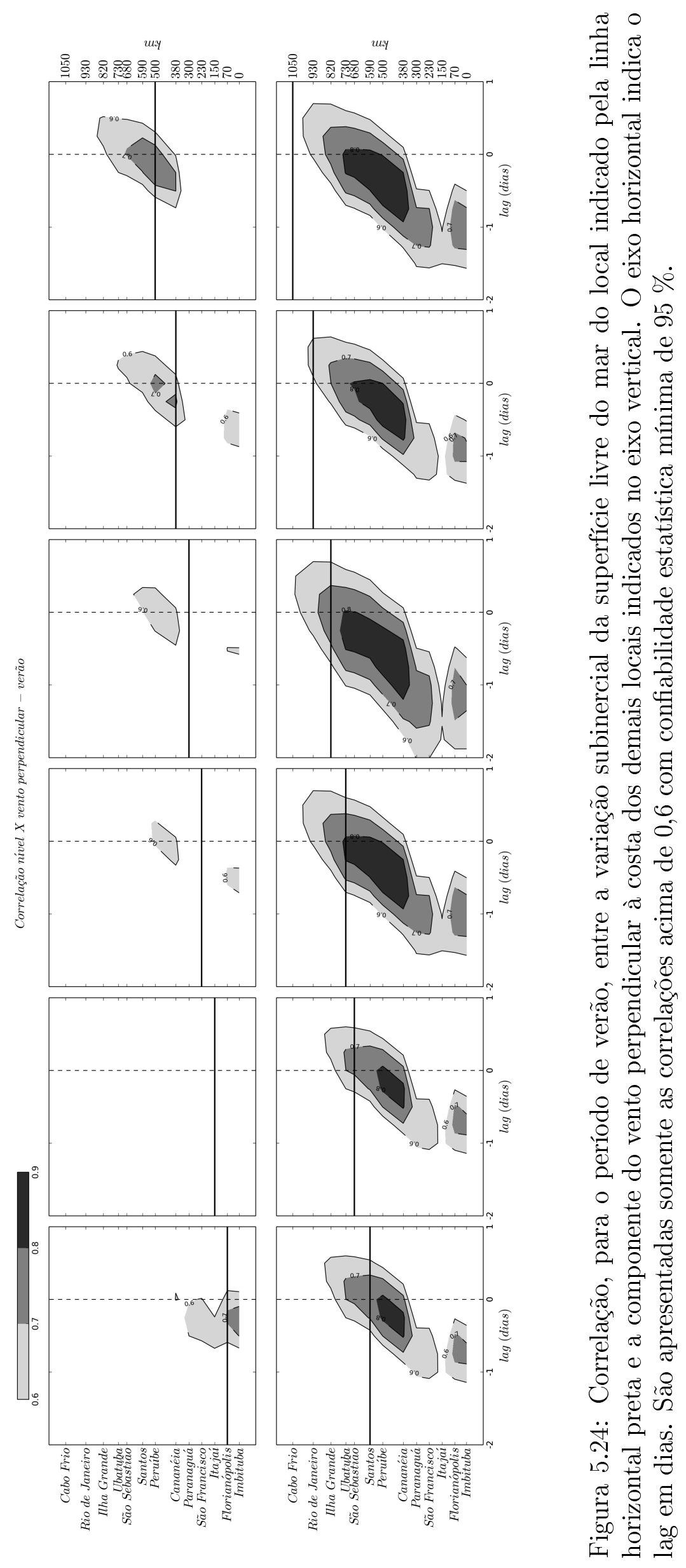




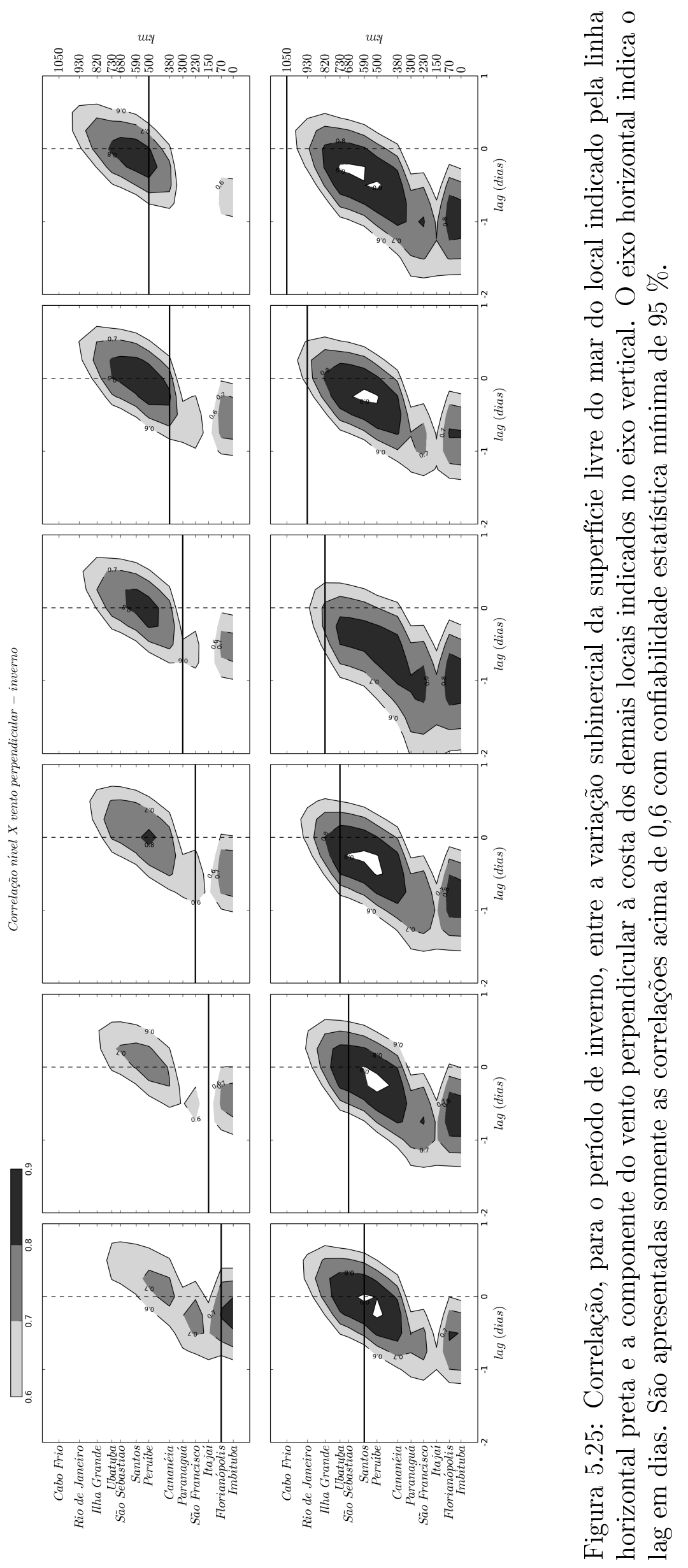




\subsubsection{Resposta à forçantes externas da Plataforma Continen- tal Sudeste}

Castro \& Lee (1995) indicam que algumas OS observadas na PCSE podem ser geradas ao sul desta região. O mesmo foi descrito por Melo et al. (2003) para estudo na costa de SC sugerindo propagação de OPC desde o Uruguai; Filippo et al. (2012) mostram que algumas OS se propagam para o norte a partir da costa da Argentina. França (2013) mostrou, a partir de dados de séries modeladas, que a região entre $42^{\circ} \mathrm{S}$ e $45^{\circ} \mathrm{S}$ (litoral central da Argentina) é a região mais setentrional onde foram encontradas OS aprisionadas na PC. Reboite et al. (2009) indicou essa mesma última região como sendo de grande atividade de ciclogênese atmosférica, juntamente com a região próxima a $35^{\circ} \mathrm{S}$ (litoral do Uruguai).

Baixas correlações foram obtidas entre os dados de elevação do nível do mar aqui modelados e aqueles coletados na região sul da PCSE (Figuras 4.16 e 4.17).

Para avaliar a influência de forçantes externas sobre as OS na PCSE, repetimos o experimento $1 \mathrm{~A}$ (ventos reais de verão) inserindo na borda sul do domínio modelado (Figura 3.4) oscilações do nível do mar coerentes com valores medidos em Rio Grande (RS), em marégrafo do GLOSS-Brasil, para o mesmo período da simulação. Não estavam disponíveis os dados desta última estação para o período da simulação de inverno (Experimento 1B). Estas oscilações foram inseridas no modelo com defasagem de $13 \mathrm{~h}$ (calculadas de acordo com a velocidade média de propagação das OS encontrada neste estudo - $40 \mathrm{~km} / \mathrm{h}$ - e a distância de Rio Grande até a borda sul do domínio modelado - $520 \mathrm{~km}$ ). A oscilação medida foi aplicada na costa e, ao largo, foi aplicado decaimento, confinando a perturbação na borda sul de acordo com o apresentado nas Figuras 5.15 a 5.18. O experimento 1A foi repetido duas vezes, uma considerando somente a introdução desta oscilação externa e outra a introdução desta forçante externa e os ventos reais. As séries de tempo de elevação subinercial da superfície livre do mar modelados nestes experimentos e dados medidos em estações ao longo da PCSE estão apresentadas nas Figuras 5.26 e 5.27.

A comparação visual entre os dados coletados em marégrafos e os dados modelados no experimento com a forçante externa (Figura 5.26) indica grande similaridade entre as séries, inclusive em Imbituba - GLOSS Brasil, fato este não obtido no experimento sem forçante externa (Experimento 1A - Figura 4.16). A comparação dos dados medidos em marégrafos com os dados modelados no experimento com forçante externa e ventos reais (Figura 5.27) também mostra grande similaridade em todos os locais analisados, com melhor ajuste na porção norte da PCSE. A Tabela 5.3 mostra os parâmetros de correlação entre as séries medidas e modeladas para os experimentos $1 \mathrm{~A}$ (somente vento), com forçante externa e o com forçante externa e ventos reais. 


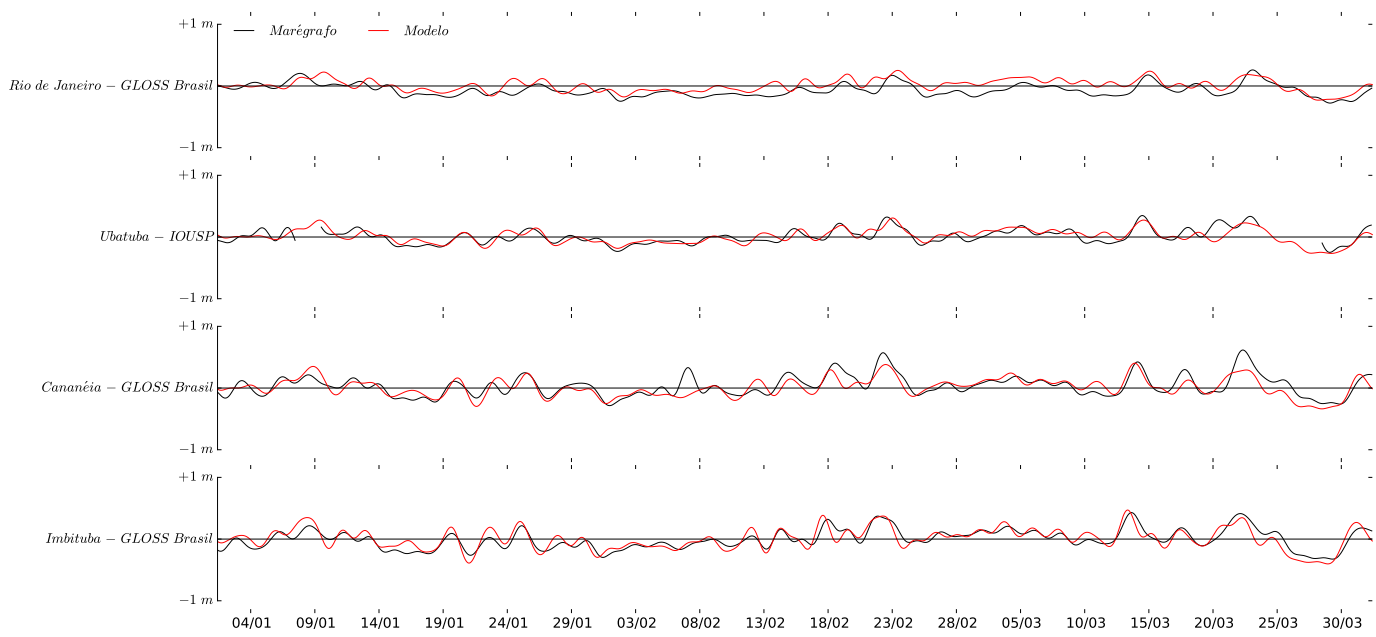

Figura 5.26: Séries de tempo de elevação subinercial da superfície livre do mar modelada (Experimento 1A - linha preta - sem vento e com forçante externa) e observada (linha vermelha) durante o verão de 2003. Os locais representativos de cada série estão listados na lateral esquerda de cada painel.

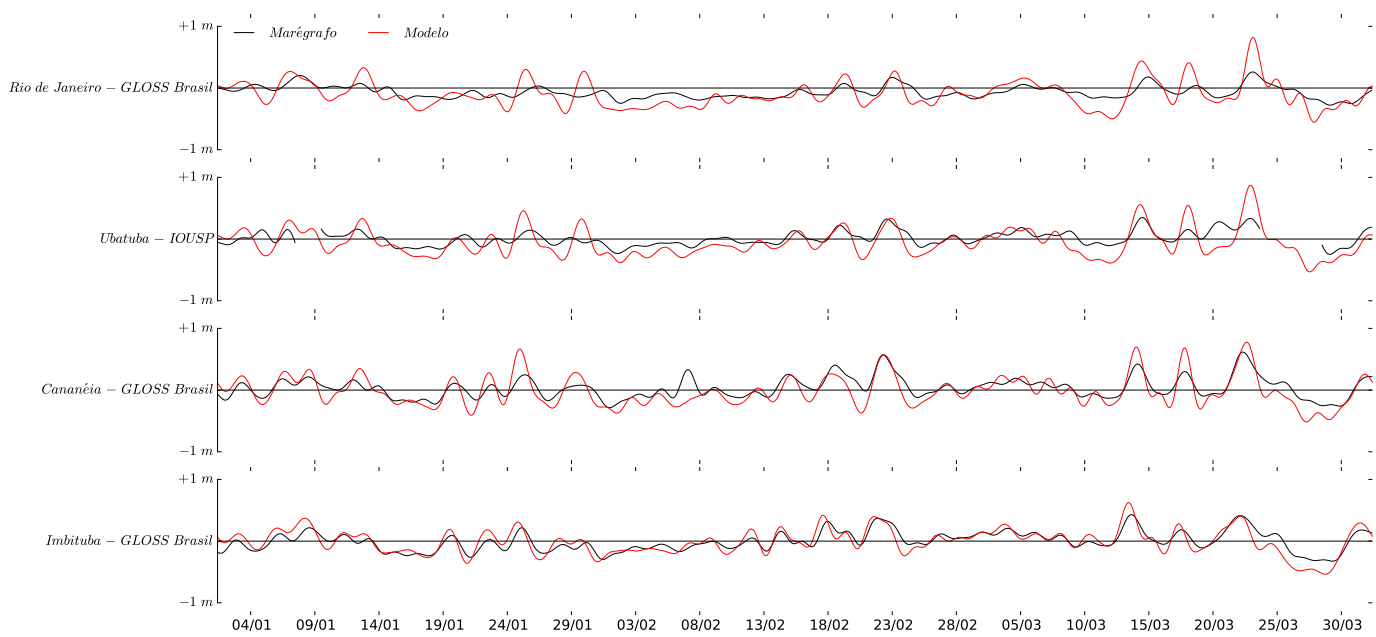

Figura 5.27: Séries de tempo de elevação subinercial da superfície livre do mar modelada (Experimento 1A - linha preta - com vento e com forçante externa) e observada (linha vermelha) durante o verão de 2003. Os locais representativos de cada série estão listados na lateral esquerda de cada painel.

Os parâmetros estatísticos comparativos mostram que com a inclusão da forçante externa nas simulações as séries medidas e modeladas apresentam maior semelhança, principalmente na porção sul da PCSE. O experimento que considerou a forçante externa e os ventos teve valores de correlação entre as séries modeladas e medidas superiores aos obtidos pelo experimento que só considerou a forçante externa. Estes experimentos corroboram, então, as afirmações de Castro \& Lee (1995), Filippo 
et al. (2012) e França (2013) sobre algumas OS serem geradas em regiões ao sul da PCSE e nela penetram como ondas livres.

A Figura 5.28 mostra as isolinhas do espectro de potência para a oscilação da superfície livre do mar do experimento $1 \mathrm{~A}$ acrescido da forçante externa. A comparação com o Experimento 1A, que não considerou a forçante externa (Figura 5.29), mostra que na porção ao sul de Cananéia a inclusão dessa forçante adiciona ao espectro energia em períodos acima de 6 dias. Houve acréscimo de energia no período de 5 dias ao sul de Florianópolis. Isso indica que parte das OS são geradas ao sul da PCSE; entretanto as oscilações com períodos entre 2 e 7 dias também podem ser geradas na região entre Paranaguá e Cananéia e se propagam para o norte.

Tabela 5.3: Correlação mínima (95\% de confiabilidade), skill e NRMS entre as séries coletadas por marégrafos e as modeladas nos Experimentos 1A (V), 1A sem vento e com forçante externa (FE) e $1 \mathrm{~A}$ com vento e forçante externa $(\mathrm{V}+\mathrm{FE})$.

\begin{tabular}{l|c|c|c}
\hline & $\mathrm{V}$ & $\mathrm{FE}$ & $\mathrm{V}+\mathrm{FE}$ \\
\hline & \multicolumn{3}{|c}{ Skill } \\
\hline Imbituba - GLOSS BRASIL & 0,36 & 0,92 & 0,91 \\
Cananéia - GLOSS BRASIL & 0,64 & 0,87 & 0,86 \\
Ubatuba - IOUSP & 0,57 & 0,88 & 0,74 \\
Rio de Janeiro - GLOSS BRASIL & 0,56 & 0,74 & 0,73 \\
\hline & \multicolumn{3}{|c}{ Correlação } \\
\hline Imbituba - GLOSS BRASIL & 0,14 & 0,89 & 0,90 \\
Cananéia - GLOSS BRASIL & 0,38 & 0,77 & 0,80 \\
Ubatuba - IOUSP & 0,33 & 0,78 & 0,67 \\
Rio de Janeiro - GLOSS BRASIL & 0,56 & 0,53 & 0,81 \\
\hline & \multicolumn{3}{|c}{ RMS } \\
\hline Imbituba - GLOSS BRASIL & 0,58 & 0,10 & 0,09 \\
Cananéia - GLOSS BRASIL & 0,18 & 0,15 & 0,12 \\
Ubatuba - IOUSP & 0,16 & 0,13 & 0,14 \\
Rio de Janeiro - GLOSS BRASIL & 0,15 & 0,22 & 0,11 \\
\hline
\end{tabular}




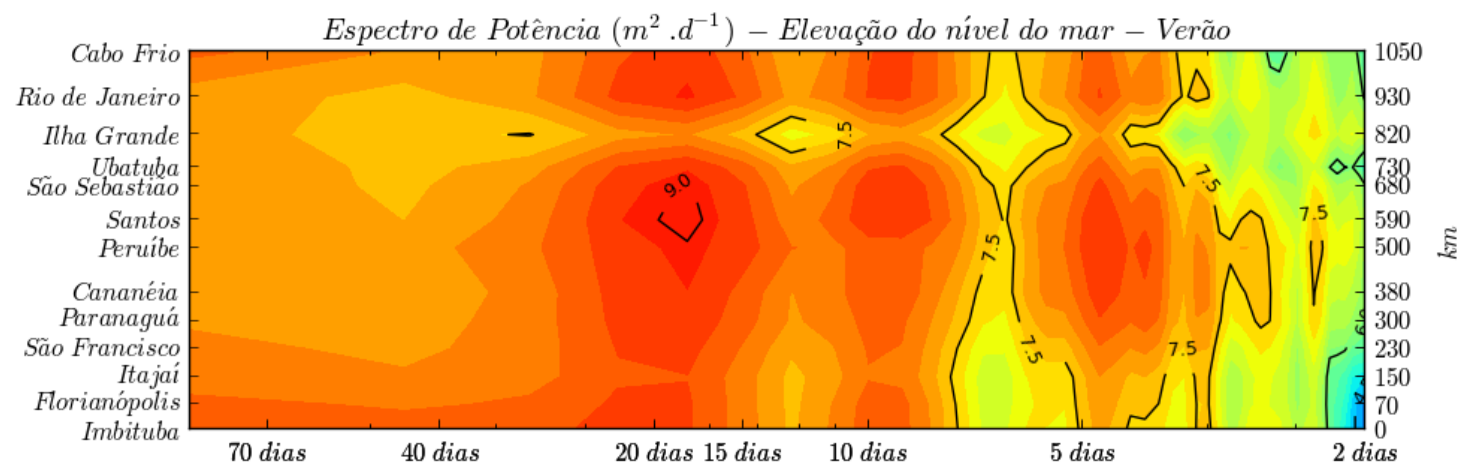

Figura 5.28: Isolinhas dos espectros de potência para a oscilação da superfície livre do mar para o verão de 2003, em função da distância ao longo da costa (ordenadas) e do período (abcissas), para o experimento 1A acrescido da forçante externa. São apresentadas as potências mínimas com confiabilidade estatística de $95 \%$ e 10,5 graus de liberdade.

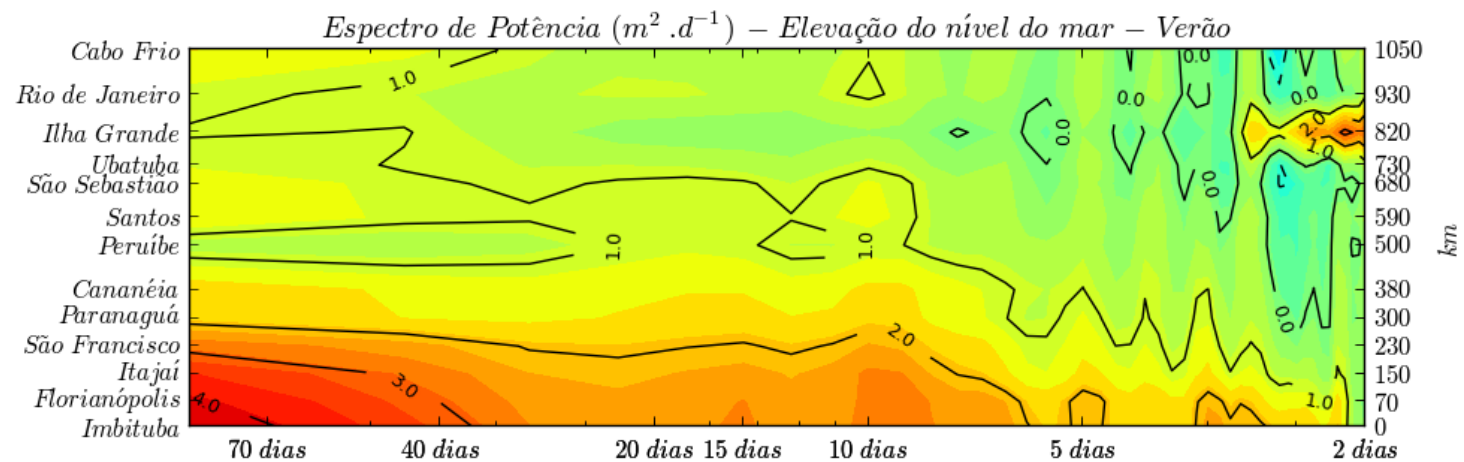

Figura 5.29: Isolinhas que representam a diferença entre os espectros de potência do experimento $1 \mathrm{~A}$ com e sem acréscimo de forçante externa, para a oscilação da superfície livre do mar para o verão de 2003 em função da distância ao longo da costa (ordenadas) e do período (abcissas). São apresentadas as potências mínimas com confiabilidade estatística de $95 \%$ e 10,5 graus de liberdade.

\subsubsection{Gênese das oscilações subinerciais na Plataforma Con- tinental Sudeste}

Enfield \& Allen (1983) discutiram métodos para obter a direção do vento local dominante que provoca perturbações no nível do mar e destacaram a equação apresentada por Garret \& Toulany (1982):

$$
\theta_{d}=\tan ^{-1}\left[T\left(S_{u} / S_{v}\right)\right]
$$


onde, $\theta_{d}$ é a direção do vento dominante, $S_{u}$ e $S_{v}$ são os desvios padrão das componentes zonal e meridional do vento, e $T$ é dado por $T=\left(C_{2}-C C_{1}\right) /\left(C_{1}-C C_{2}\right)$, com $C, C_{1}$ e $C_{2}$ sendo as correlações entre a oscilação do nível do mar e a componente zonal do vento, entre a oscilação do nível do mar e a componente meridional do vento, e entre as componentes zonal e meridional do vento. A Tabela 5.4 mostra as direções do vento dominante sobre o nível do mar na PCSE para as oscilações entre 3-5, 7-9 e 17-19 dias. Estes resultados foram obtidos a partir do Experimento 1A acrescido da forçante remota, e as oscilações modeladas foram filtradas com filtro passa-banda nos períodos de análise. Foi utilizado o mesmo filtro descrito no Capítulo 2. Os resultados obtidos para os período entre 3-5 e 17-19 dias são concordantes com Castro \& Lee (1995) para as oscilações com período entre 6-7 e 9-12 dias, respectivamente, para o inverno. Na região central da PCSE as perturbações com período entre 7-9 dias têm direções dos ventos dominantes similares às obtidas para as perturbações com período de 3-5 dias. Castro \& Lee (1995) indicaram que na banda entre 9-12 dias o nível do mar responde mais eficientemente aos ventos de direção sudeste-noroeste, que são os ventos quase paralelos à costa na porção sul da PCSE e quase perpendiculares à costa na porção norte da PCSE. Na banda entre 6-7 dias o nível do mar responde mais eficientemente para ventos de sudoeste-nordeste.

Tabela 5.4: Direção em graus do vento dominante que provoca perturbações no nível do mar na Plataforma Continental Sudeste.

\begin{tabular}{l|c|c|c} 
& 3-5 dias & 7-9 dias & 17-19 dias \\
\hline Imbituba & 2 & 85 & 46 \\
Florianópolis & 4 & 76 & 55 \\
Itajaí & 353 & 28 & 39 \\
São Francisco & 353 & 8 & 42 \\
Paranaguá & 353 & 345 & 41 \\
Cananéia & 348 & 345 & 47 \\
Peruíbe & 311 & 330 & 52 \\
Santos & 340 & 326 & 83 \\
São Sebastião & 339 & 310 & 110 \\
Ubatuba & 308 & 251 & 103 \\
Ilha Grande & 259 & 296 & 216 \\
Rio de Janeiro & 346 & 212 & 97 \\
Cabo Frio & 10 & 271 & 170 \\
\hline
\end{tabular}

A partir das séries de oscilações da superfície do mar utilizadas para obter o vento dominante, calculamos a variância e comparamos com a variância subinercial total (Tabela 5.5). Os valores mostram que as oscilações com período entre 3-5 e 7-9 dias representam, juntas, cerca de $30 \%$ da variação subinercial total nas porções sul e norte da PCSE e $40 \%$ na região central. As variâncias das oscilações com período entre 17-19 dias são mais importantes na porção norte da PCSE. 
Tabela 5.5: Porcentagem da variância subinercial explicadas pelos eventos com períodos entre 3-5, 7-9 e 17-19 dias.

\begin{tabular}{l|c|c|c}
\hline & 3-5 dias & 7-9 dias & 17-19 dias \\
\hline Imbituba & 22 & 5 & 8 \\
Florianópolis & 24 & 5 & 9 \\
Itajaí & 28 & 4 & 9 \\
São Francisco & 31 & 4 & 9 \\
Paranaguá & 34 & 4 & 9 \\
Cananéia & 36 & 4 & 9 \\
Peruíbe & 35 & 5 & 9 \\
Santos & 32 & 6 & 11 \\
São Sebastião & 30 & 6 & 12 \\
Ubatuba & 29 & 6 & 14 \\
Ilha Grande & 22 & 4 & 9 \\
Rio de Janeiro & 31 & 6 & 13 \\
Cabo Frio & 28 & 6 & 12 \\
\hline
\end{tabular}

No sul da PCSE foi observado que, no verão (inverno), ocorre a passagem de aproximadamente 10 (11) FF. Na porção norte foram observadas passagens de 4 e 9 FF para o verão e inverno, respectivamente. As FF médias que passam pelo sul da PCSE mas não atingem o norte se deslocam até a região norte de SP. Os experimentos com eventos médios mostraram que tanto as $\mathrm{FF}$ que passam somente pela porção sul quanto aqueles que percorrem toda a extensão da PCSE geram perturbações que se propagam para o norte, com a costa à esquerda. Estas perturbações ganham amplitude até a região próxima à Cananéia e, a partir deste ponto, propagam-se com pouca variação de amplitude. Estas pertubações deslocam-se para o norte confinadas dentro da PCSE, com amplitude máxima na costa, decaindo para o largo. Na região sul da PCSE as perturbações geradas são correlacionadas positivamente com a componente do vento local paralela à costa e, na região entre Paranaguá e Cananéia, melhor correlacionadas com a componente do vento local perpendicular à costa. Ao norte de Paranaguá as perturbações são melhor correlacionadas com o vento paralelo à costa da região entre São Francisco e Imbituba. Estas oscilações deslocam-se para o norte com comprimento de onda de aproximadamente $2000 \mathrm{~km}$ e velocidade $11 \mathrm{~m} / \mathrm{s}$. Todas estas características indicam que tais perturbações se deslocam pela PCSE em forma de OPC, conforme a teoria clássica de Gill \& Schumann (1974). Tais perturbações têm períodos destacados entre 3-5, 7-9 e 17-19 dias no verão, e entre 3-5, 5-8, 10-11 e 19-20 dias no inverno. Para o verão foi observado que as oscilações maiores que 3 dias podem ser geradas ao sul da PCSE; entretanto as oscilações com período entre 2 e 7 dias são também geradas localmente.

A Figura 5.30 apresenta a região de formação de OPC sobre a PCSE, a região de máximo deslocamento das FF médias que não percorrem toda a extensão da PCSE, 
o sentido de propagação de OPC sobre a PCSE e a região de confinamento destas ondas.

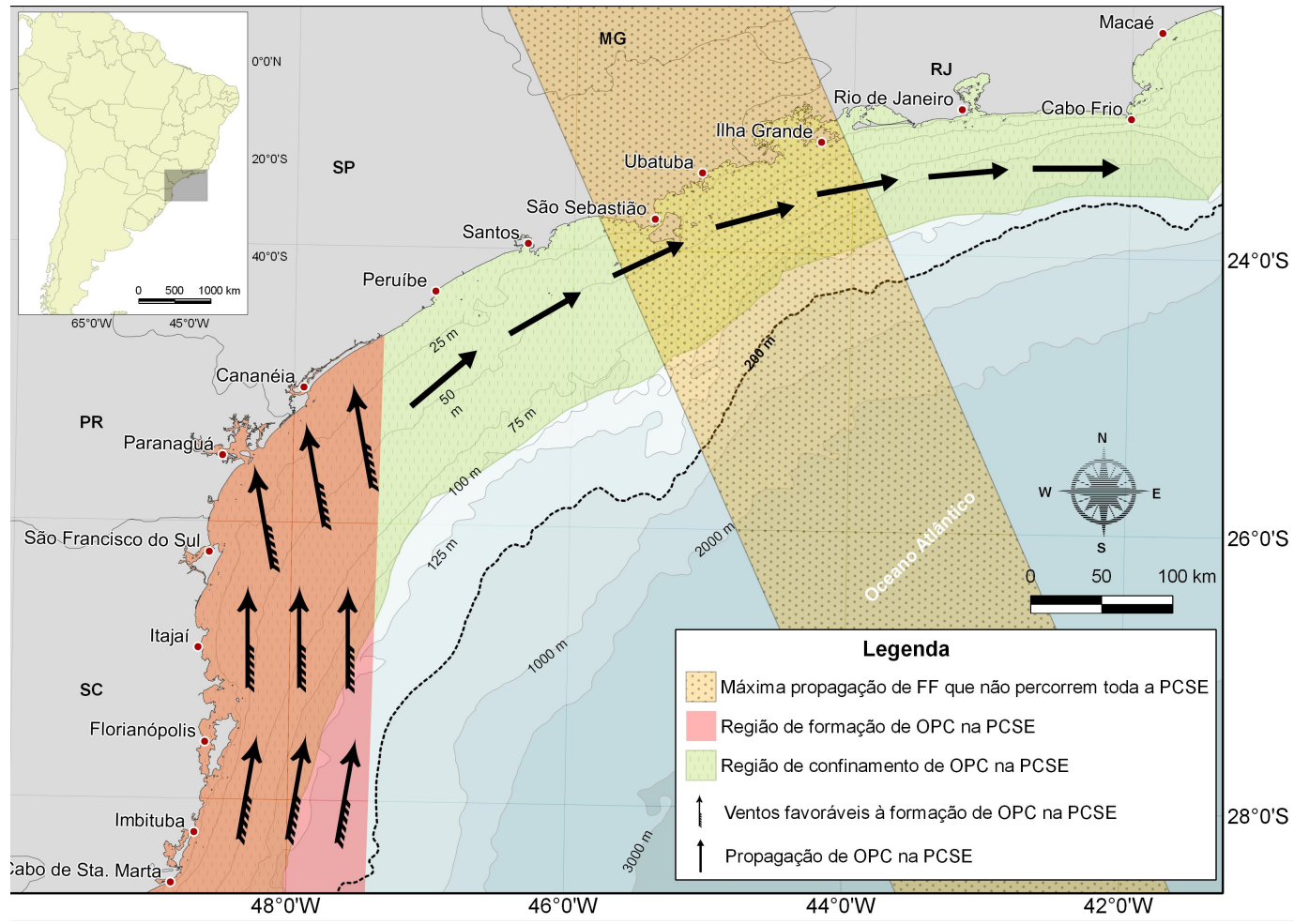

Figura 5.30: Regiões de formação e propagação de OPC na PCSE. As setas indicam os ventos favoráveis para a formação de OPC na PCSE e o sentido de deslocamento destas após sua formação. 


\section{Capítulo 6}

\section{Conclusões}

As principais conclusões obtidas neste estudo são:

- Na porção sul da PCSE ocorreu a passagem de 3,6 FF/mês no inverno e 3,4 $\mathrm{FF} /$ mês no verão;

- Na porção norte da PCSE, no inverno passaram 2,9 FF/mês e no verão 1,3 FFs/mês;

- Existe maior número de FF que percorreram toda a extensão da PCSE no inverno;

- As FF médias que não percorreram toda a extensão da PCSE alteram a direção do campo de ventos, pressão e temperatura atmosférica nas porções sul e central, não afetando de forma significativa as características atmosféricas da porção norte da PCSE;

- Na porção sul da PCSE as FF de verão apresentam velocidade de deslocamento superiores às FF de inverno. Contudo, na porção norte da PCSE as FFs sofrem desaceleração e a velocidade média final das $\mathrm{FF}$ de inverno foram superiores às de verão $\left(30 \mathrm{~km} \cdot \mathrm{h}^{-1}\right.$ e $20 \mathrm{~km} \cdot \mathrm{h}^{-1}$, respectivamente);

- Após a passagem de FF por toda a PCSE, ocorreu a propagação de oscilações subinerciais da superfície do mar confinada junto à costa, com comprimento de onda de aproximadamente $2000 \mathrm{~km}$, duração de 50 h e amplitude média de 30 $\mathrm{cm}$, tanto no verão quanto no inverno. Estas perturbações geradas ganharam amplitude até as imediações de Paranaguá-Cananéia e se propaga para a região norte da PCSE;

- No cenário em que os ventos na porção norte da PCSE permaneceram inalterados, mas no mesmo período ocorreu a passagem de FF na porção sul da 
PCSE, oscilações subinerciais da superfície do mar foram geradas e se propagaram para o norte com características semelhantes (com exceção da altura) daquelas geradas por FF que percorreram toda a PCSE;

- As oscilações subinerciais da superfície livre do mar na porção norte da PCSE foram melhor correlacionadas com a componente do vento perpendicular à costa da região de Paranaguá-Cananéia e com a componente do vento paralelo à costa da região de Imbituba-São Francisco;

- Forçantes externas à PCSE são importantes para oscilações subinerciais da superfície livre do mar observadas, sobretudo para aquelas com períodos superiores a 7 dias;

- As oscilações subinerciais que possuíam períodos inferiores à 7 dias e que foram geradas desde o extremo sul da PCSE até a região de Cananéia-Paranaguá contribuíram com cerca de $40 \%$ da variância das oscilações subinerciais da PCSE;

- As oscilações subinerciais que possuíam períodos superiores a 9 dias e que foram geradas em regiões ao sul da PCSE foram responsáveis por cerca de $12 \%$ da variância das oscilações subinerciais da PCSE;

- As oscilações subinerciais analisadas têm características de Ondas de Plataforma Continental. 


\section{Capítulo 7}

\section{Considerações Finais}

Para os resultados aqui apresentados e discutidos deve ser considerado que, principalmente na PCI e PCE, não foram representadas as variações laterais de densidade. Os campos de massa são associadas à descarga continental, as intrusões durante o inverno de águas frias provenientes do sul do Brasil, a ressurgência costeira de Cabo Frio e a presença da CB na PCE podem influencias as OS estudadas. Sugere-se, então, para trabalhos futuros, estudar como é a interação entre as OS e estas estruturas termohalinas e, adicionalmente, como é a interação das componentes internas (baroclínicas) destas OS com a ressurgência costeira de Cabo Frio, na porção norte da PCSE. 


\section{Referências Bibliográficas}

Adams, J. K. \& Buchwald, V. T. (1969), 'The generation of continental shelf waves', Journal of Fluid Mechanics 35, 815:826.

Alves, M. A. (1992), 'Correntes de maré e inerciais na plataforma continental ao largo de ubatuba (sp)', Dissertação de Mestrado. Instituto Oceanográfico da Universidade de São Paulo.

Andrade, K. M. (2007), 'Climatologia e comportamento dos sistemas frontais sobre a américa do sul', Dissertação de Mestrado. Instituto Nacional de Pesquisas Espaciais (INPE).

Antonov, J. I., Seidov, D., Boyer, T. P., Locarnini, R. A., Mishonov, A. V., Garcia, H. E., Baranova, O. K., Zweng, M. M. \& Johnson, D. R. (2010), World ocean atlas 2009, volume 2: salinity, Technical report, NOAA Atlas NESDIS 69, U.S. Government Printing Office, Washington, D.C.

Battisti, D. \& Hickey, B. (1984), 'Application of remote wind-forced coastal trapped wave theory to the oregon and washington coasts', American Meteorological Society 14, 887-903.

Brink, K. H. (1982), 'A comparison of long coastal trapped wave theory with observations off peru', Journal of Physical Oceanography 12, 897-913.

Caldas, M. J. (1978), 'Características da estrutura e circulação das águas da plataforma continental entre cabo frio e ilha de santa catarina em janeiro de 1968', Dissertação de mestrado. Instituto Oceanográfico da Universidade de São Paulo.

Camargo, R. \& Harari, J. (1994), 'Modelagem numérica de ressacas na plataforma sudeste do brasil a partir de cartas sinóticas de pressão atmosférica de superfície', Boletim do Instituto Oceanográfico da USP 42(1), 19-34.

Campos, R. M., Camargo, R. \& Harari, J. (2010), 'Caracterização de eventos extremos do nível do mar em santos e sua correspondência com as reanálises do modelo ncep no sudoeste do atlântico sul', Revista Brasileira de Meteorologia 25(2), 175184. 
Castro, B. M. (1985), 'Subtidal response to wind forcing in the south brazil bight during winter', PhD Dissertation. University of Miami, Rosenstiel School of Marine and Atmospheric Science.

Castro, B. M. (1996), 'Correntes e massas de água da plataforma continental norte de são paulo', Tese de livre docência. Instituto Oceanográfico da Universidade de São Paulo.

Castro, B. M. \& Lee, T. (1995), 'Wind forced sea level variability on the southeast brazilian shelf', Journal of Geophysical Research 100(8), 16045-16056.

Castro, B. M. \& Miranda, L. B. (1998), 'Physical oceanography of the western atlantic continental shelf located between $4 \mathrm{n}$ and $24 \mathrm{~s}$, coastal segment $(4 \mathrm{w})$ ', The sea 11, 209-251.

Castro, B. M., Miranda, L. B. \& Miyao, S. Y. (1987), 'Condições hidrográficas na plataforma continental ao largo de ubatuba: variações sazonais e em média escala', Boletim do Instituto Oceanográfico 35(2), 135-151.

Castro, B. M., Pereira, A. F., Dottori, M., Paschoal, G. C. A., Caroli, A. D., Silveira, I. C. A. \& Amor, C. C. (2014), 'Correntes e massas de água na plataforma continental da bacia de santos.', submetido.

Cavalcante, S. L. S. (2010), 'Estudo da influência da dinâmica da plataforma continental nas baías de ilha grande e sepetiba via aninhamento de modelo numérico costeiro a modelo mumérico oceânico', Tese de Doutorado. Universidade Federal do Rio de Janeiro, Engenharia Oceânica, COPPE.

Cavalcanti, I. F. A. \& Kousky, V. E. (2003), Climatology of south american cold fronts, in 'International Conference on Southern Hemisphere Meteorology and Oceanography', Wellington, Nova Zelândia,.

Coelho, A. L. (2007), 'Resposta da plataforma continental sudeste a ventos sazonais e sinóticos de verão: estudos numéricos', Tese de doutorado. Instituto Oceanográfico da Universidade de São Paulo.

Colebrook, C. F. \& White, C. M. (1937), 'Experiments with fluid friction in roughened pipes', Proceedings of the Royal Society 161, 367.

Costa, M. C. (2010), 'Influência das tensões do vento na variação do nível médio do mar na região costeira de cananéia (sp): filtragem numérica e espectral', Dissertação de Mestrado. Universidade Federal de Itajubá, Programa de Pós Graduação em Meio Ambiente e Recursos Hídricos. 
Coutinho, P. N. C. (2005), 'Levantamento do estado da arte da pesquisa dos recursos vivos marinhos do brasil - oceanografia geológica', Programa REVIZEE .

CPTEC/INPE (1996), Boletim Climanálise, Vol. 21 of 1, CPTEC/INPE.

Csanady, G. T. (1977), The coastal jet conceptual model in the dynamics of shallow seas, in I. Goldberg, N. O’Brian \& J. H. Steele, eds, 'The Sea', John Wiley Science, New York, pp. 117-144.

Cutchin, D. L. \& Smith, R. L. (1973), 'Continental shelf waves: low-frequency variations in sea level and currents over the oregon continental shelf', Journal of Physical Oceanography 3, 73-82.

da Silva, M. G. A. J. \& Dias, M. A. F. S. (2000), A estatística dos transientes na américa do sul, in 'Anais do XI Congresso Brasileiro de Meteorologia', Rio de Janeiro.

Dake, C. \& Jilan, S. (1987), 'Continental shelf waves along the coast of china', Acta. Oceanologica Sinica 6, 317-334.

de Caroli, A., Gregório, H. P. \& Pereira, A. F. (2010), Avaliação de bancos batimétricos globais na região sul-sudeste do brasil e implementação de nova base batimétrica, in 'XXIII Semana Nacional de Oceanografia', Itanhaém - SP.

Deltares (2010), Delft3D-FLOW User Manual 3.28.10, WL | Delft Hydraulics, Holanda.

Dottori, M. \& Castro, B. M. (2009), 'The response of the são paulo continental shelf, brazil, to synoptic winds', Ocean Dynamics 59(4), 603-614.

Eckart, C. (1958), 'Properties of water ii: the equation of state of water and sea water at low temperatures and pressures', American Journal Science 256, 225-240.

Egbert, G. \& Erofeeva, L. (2002), 'Efficient inverse modeling of barotropic ocean tides', Journal Atmospheric Oceanic Technology 19, 183-204.

Elgar, S. (1987), 'Bias of effective degrees of freedom of a spectrum', Journal of Waterway, Port, Coastal, and Ocean Engineering 113(1), 77-82.

Eliot, M. \& Pattiaratchi, C. (2010), 'Remote forcing of water levels by tropical cyclones in southwest australia', Continental Shelf Research 30(14), 1549 - 1561.

Emery, W. J. \& Thomson, R. E. (2001), Data analysis methods in Physical Oceanography: Second and revised edition, 2 edn, Elsevier Science. 
Emilson, I. (1962), 'As correntes marítimas no canal de são sebastião', Ciência e Cultura 14(4), 269-270.

Enfield, D. B. \& Allen, J. S. (1983), 'The generation and propagation of sea level variability along the pacific coast of mexico', Journal of Physical Oceanography 13(6), 1012-1033.

Engquist, B. \& Majda, A. (1977), 'Absorbing boundary conditions for the numerical simulation of waves.', Mathematics of Computation 31, 629-651.

Engquist, B. \& Majda, A. (1979), 'Radiation boundary conditions for acoustic and elastic wave calculations', Communications on Pure and Applied Mathematics 32, 313-357.

Filippo, A., Kjerfve, B., Jr, A. R. T. \& Fernandes, A. M. (2012), 'Low-frequency variability of sea level along the mid-atlantic coast of south america, in 1983', Revista Brasileira de Geofísica 30(1), 5-14.

Filippo, A. M. (2003), 'Variabilidade do nível do mar em função de eventos meteorológicos de baixa frequência', Tese de Doutorado. Universidade Federal Fluminense.

França, B. R. L. (2013), 'Ondas confinadas costeiras na plataforma continental sulsudeste do brasil', Dissertação de Mestrado. Universidade Federal do Rio de Janeiro, Engenharia Oceânica, COPPE.

Freeland, H., Boland, F., Church, J., Clarke, A., Forbes, A., Huyer, A., Smith, R., Thompson, R. \& White, N. (1986), 'The australian coastal experiment: a search for coastal trapped waves', Journal of Physical Oceanography 16, 1230-1249.

Garret, C. \& Toulany, B. (1982), 'Sea level variability due to meteorological forcing in the northeast gulf of st. lawrence.', Journal of Geophysical Research 87, 19681978.

Gill, A. E. \& Schumann, E. H. (1974), 'The generation of long shelf waves by the wind', Journal of Physical Oceanography 4, 83-90.

Hamon, B. V. (1962), 'The spectrums of mean sea level at sydney, coffs harbour, and lord howe island.', Journal of Geophysical Research 67(13), 5147-5155.

Hamon, B. V. (1976), 'Generation of shelf waves on the east australian coast by wind stress', Mém. Soc. R. Sci. Li'ege 10, 359-367.

Hess, K. W. \& Bosley, K. T. (1992), 'Methodology for validation of a tampa bay circulation model', Proceedings, 2nd International Conference on Estuarine and Coastal Modeling, Tampa, Florida pp. 83-94. 
Huang, H. (2011), Finite volume coastal ocean model (fvcom) 3d hydrodynamic model comparison, Technical report, Texas Water Development Board (TWDB). $42 \mathrm{p}$.

Jordi, A., Orla, A., Basterretxea, G. \& Tintoré, J. (2005), 'Coastal trapped waves in the northwestern mediterranean', Continental Shelf research 25, 185-196.

Kanamitsua, M., Kumarb, A., Juangc, H.-M. H., Schemmd, J.-K., Wange, W., Yangf, F., Hongg, S.-Y., Pengh, P., Cheni, W., Moorthij, S. \& Jik, M. (2002), 'Ncep dynamical seasonal forecast system 2000', Bulletin of the American Meteorological Society 83(7), 1019-1037.

Kundu, P. \& Allen, J. (1976), 'Some three-dimensional characteristics of lowfrequency current fluctuations near the oregon coast', Journal of Physical Oceanography 6, 181-199.

LeBlond, P. H. \& Mysak, L. A. (1977), The sea, Vol. 6, E. D. Goldberg, I. N. Cave, J. J. O'Brien, J. H. Steele, New York, chapter Trapped coastal waves and their role in shelf dynamics.

Lemos, C. F. \& Calbete, N. O. (1996), 'Sistemas frontais que atuaram no brasil de 1987 a 1995', Climanálise especial, edição comemorativa de 10 anos . MCT/INPECPTEC.

Locarnini, R. A., Mishonov, A. V., Antonov, J. I., Boyer, T. P., Garcia, H. E., Baranova, O. K., Zweng, M. M. \& Johnson, D. R. (2010), World ocean atlas 2009, volume 1: temperature, Technical report, NOAA Atlas NESDIS 68, U.S. Government Printing Office, Washington, D.C.

Martinez, J. A. \& Allen, J. S. (2004), 'A modeling study of coastal trapped wave propagation in the gulf of california. part i: response to remote forcing', Journal of Physical Oceanography 34, 1313-1331.

Mazzini, P. L. F. (2009), 'Correntes subinerciais na plataforma continental interna entre peruíbe e são sebastião: observações', Dissertação de mestrado. Instituto Oceanográfico da Universidade de São Paulo.

McClimans, T. A. (1986), Estuarine fronts and river plumes., in J. D. . W. van Leussen, ed., 'Physical Processes in Estuaries', Springer-Verlag, New York, pp. 5569.

Medeiros, S. C., Hagen, S. C., Chaouch, N., Feyen, J., Temimi, M., Weishampel, J. F., Funakoshi, Y. \& Khanbilvardi, R. (2013), 'Assessing the performance of a 
northern gulf of mexico tidal model using satellite imagery', Remote Sens. 5, 56625679 .

Melo, E., Pimenta, F. M., Mendes, D. A., Hammes, G. R., Araújo, C. E., Franco, D., Alves, J. H. G. M., Barletta, R. C., Souto, A. M., Castelão, G., Pereira, N. C. \& Branco, F. V., eds (2003), A real time, on-line coastal information program in Brazil, Proc. Sixth Intern, Conf. on Coastal and Port Eng. in Developing Countries, COPEDEC VI, Colombo Sri Lanka.

Menezes, D. C. (2007), 'Contribuições metodológicas para análise das flutuações atmosféricas e oceanográficas de baixa frequência na costa do estado do rio de janeiro.', Dissertação de Mestrado. Universidade Federal do Rio de Janeiro, Engenharia Oceânica, COPPE.

Miller, J. L. \& Lee, T. N. (1995), 'Gulf stream meanders in the south atlantic bight, part i: Scaling and energetics', Journal of Geophysical Research 100, 6687-6704.

Miranda, L. B. (1982), 'Análise de massas de água da plataforma continental e da região oceânica adjacente: Cabo de são tomé (rj) a ilha de são sebastião (sp)', Tese de livre docência. Instituto Oceanográfico da Universidade de São Paulo.

Miranda, L. B. (1985), 'Forma de correlação t-s de massas de água das regiões costeira e oceânica entre o cabo de são tomé (rj) e a ilha de são sebastião (sp)', Boletim do Instituto Oceanográfico 33, 269-270.

Miranda, L. B. \& Katsuragawa, M. (1991), 'Estrutura térmica na região sudeste do brasil (outubro/novembro de 1988)', Publicação Especial do Instituto Oceanográfico $\mathbf{1}(8), 1-14$.

Moreira, M. H. R. (1998), 'Circulação na plataforma interna do litoral norte do estado de são paulo', Dissertação de mestrado. Instituto Oceanográfico da Universidade de São Paulo.

NOAA (2011), The tampa bay operational forecast system (tbofs): Model development and skill assessment, Technical report, National Oceanic and Atmospheric Administration. $105 \mathrm{p}$.

Oliveira, A. S. (1986), 'Interações entre sistemas frontais na américa do sul e convecção na amazônia', Dissertação de Mestrado. Instituto Nacional de Pesquisas Espaciais - INPE.

Oliveira, M. M. F. (2004), 'Redes neurais artificiais na predição da maré meteorológica em paranaguá (pr)', Dissertação de Mestrado. Universidade Federal do Rio de Janeiro, Engenharia Oceânica, COPPE. 
Oliveira, M. M. F., Ebecken, N. F. F., Santos, I. A., Caloba, L. P. \& Oliveira, J. L. F. (2007), 'Modelagem da maré meteorológica utilizando redes neurais artificiais: uma aplicação para a baía de paranaguá - pr, parte 2: Dados meteorológicos da reanáliso do ncep/ncar', Revista Brasileira de Meteorologia vv(1), 53-62.

Pereira, A. F., Belem, A. L., Castro, B. M. \& Geremias, R. (2005), 'Tide-topography interaction along the eastern brazilian shelf', Continental Shelf Research 25, 15211539.

Phillips, N. A. (1957), 'A coordinate system having some special advantages for numerical forecasting', Journal of Meteorology 14(1), 184-185.

Pimenta, F. M., Melo, E., Franco, D. \& Zavialov, P. O. (2006), 'Assessment of santa catarina shelf currents through the analysis of indirect measurements', Journal of Coastal Research 39, 651-655.

Rahy, M. Q. T. (2006), 'Correntes subinerciais e ondas de plataforma continental presentes na costa sudeste do brasil', Dissertação de Mestrado. Universidade de São Paulo, Instituto Oceanográfico.

Rao, V. B., Santo, C. E. \& Franchito, S. H. (2002), 'A diagnosis of rainfall over south america during the 1997/98 el niño event. part i: Validation of ncep/ncar reanalysis rainfall data.', Journal of Climate 15, 502-511.

Reboite, M. S., Ambrizzi, T. \& Rocha, R. P. (2009), 'Relationship between the southern annular mode and southern hemisphere atmospheric systems', Revista Brasileira de Meteorologia 24(1), 48-55.

Rezende, J. H. M. (2003), 'Intrusões da água central do atlântico sul na plataforma continental sudeste durante o verão', Tese de doutorado. Instituto Oceanográfico da Universidade de São Paulo.

Robinson, A. R. (1964), 'Continental shelf waves and the response of sea level to weather systems', Journal of Geophysical Research 69, 367-368.

Rodrigues, M. L. G., Franco, D. \& Sugahara, S. (2004), 'Climatologia de frentes frias no litoral de santa catarina', Revista Brasileira de Geofísica 22(2), 135-151.

Romea, R. \& Smith, R. (1983), 'Further evidence for coastal trapped waves along peru coast', American Meteorological Society 13, 1341-1365.

Ruffato, D. G. (2011), 'Circulação na plataforma continental interna e média do estado de são paulo durante o verão: estudos numéricos', Dissertação de Mestrado. Instituto Oceanográfico da Universidade de São Paulo. 
Samuels, B. \& Cox, M. (1987), 'Data set atlas for ocean modeling.', Ocean Model $75,1-3$.

Santos, L. F. S. (2009), 'Variabilidade subinercial das correntes da plataforma continental ao largo de cabo frio (rj): observações', Dissertação de mestrado. Instituto Oceanográfico da Universidade de São Paulo.

Schumann, E. H. \& Brink, K. H. (1990), 'Coastal trapped waves off the coast of south africa: generation, propagation and current structures', Journal of Physical Oceanography 20(8), 1206-1218.

Schummann, E. (1983), 'Long-period coastal trapped waves on the southeast coast of southern africa', Continental Shelf Research 2, 97-107.

Silva, N. P. (2013), 'Extremos de vento sobre o oeste do oceano atlântico sul: Análise direcional das ocorrências', Dissertação de Mestrado. Universidade de São Paulo, Instituto de Astronômia, Geofísica e Ciências Atmosféricas.

Skielka, U. T. (2007), 'Relatório final de pesquisa de iniciação científica', Tese de Doutorado. Departamento de Ciências Atmosféricas, Instituto de Astronomia, Geofísica e Ciências Atmosféricas. Universidade de São Paulo.

Smith, S. D. \& Banke, E. G. (1975a), 'Variation of the sea surface drag coefficient with wind speed', Quarterly Journal of the Royal Meteorological Society 101, 665673.

Smith, S. D. \& Banke, E. G. (1975b), 'Variation of the sea-surface drag coefficient with wind speed', Journal Royal Meteorology Society 101(1), 665-673.

Souza, M. C. A. (2000), 'A corrente do brasil ao largo de santos: medições diretas', Dissertação de mestrado. Instituto Oceanográfico da Universidade de São Paulo.

Stech, J. L. \& Lorenzzetti, J. A. (1992), 'The response of the south brazil bight to the passage of winter time cold fronts', Journal Geophysical Research 97, 9507-9520.

Truccolo, E., Franco, D. \& Schettini, C. A. F. (2006), 'The low frequency sea level oscillations in the northern coast of santa catarina, brazil', Journal of Coastal Research 39, 547-552.

Uaissone, A. J. R. (2004), 'Influência das forçantes atmosféricas em mesoescala sobre o nível médio do mar em piraquara, rj', Dissertação de Mestrado. Universidade Federal do Rio de Janeiro, Engenharia Oceânica, COPPE. 
Uittenbogaard, R. E., van Kester, J. A. T. M. \& Stelling, G. S. (1992), 'Implementation of three turbulence models in 3d-trisula for rectangular grids', Tech. Rep. - Delft Hydraulics, Delft, The Netherlands. .

Valentim, S. S. (2012), 'Análise das variações do nível médio do mar (nmm) em ubatuba (sp) à partir de dados maregráficos', Dissertação de Mestrado. Universidade Federal de Itajubá, Programa de Pós Graduação em Meio Ambiente e Recursos Hídricos.

Varejão-Silva, M. A. (2006), Meteorologia e climatologia, Versão Digital. 449 p.

Vasques, A. C., Franchito, S. H., Rao, V. B., Santo, C. M. E. \& Conforte, J. C. (2009), 'Comparação entre diferentes fontes de dados de precipitação sobre a américa do sul com ênfase no brasil', Boletim SBMET pp. 5-16.

Wainer, I. \& Tascheto, A. S. (2006), Climatologia na região entre o cabo de são tomé (rj) e o chuí (rs), diagnóstico para os períodos relativos aos evantamentos pesqueiros do programa revizee., in C. L. D. B. Rossi-Wongtschowski \& L. S.P. Madureira., eds, 'O Ambiente Oceanográfico da Plataforma Continental e do Talude na Região Sudeste-Sul do Brasil', EDUSP, pp. 121-160.

Walters, J. C. \& Heston, C. (1982), 'Removing the tidal-period variations from time-series data using low-pass digital filters', Journal of Physical Oceanography 12(1), 112-115.

Warner, J. C., Geyer, W. R. \& Lerczak, J. A. (2005), 'Numerical modeling of an estuary: a comprehensive skill assessment', Journal of Geophysical Research $\mathbf{1 1 0}(1), 13$.

Wilmott, C. J. (1981), 'On the validation models', Physical Geography 2(1), 184-194.

Yankovsky, A. \& Garvine, R. (1998), 'Subinertial dynamics on the inner new jersey shelf during the upwelling season', Journal of Physical Oceanography 28, 24442458 .

Zembruski, S. G. (1979), Geomorfologia da margem continental brasileira e das áreas oceânicas adjacentes., in R. de Janeiro PETROBRAS/CENPES/DINTEP, ed., 'Geomorfologia da margem continental brasileira e das áreas oceânicas adjacentes.', Série Projeto REMAC, pp. 129-177. 


\section{Apêndice A}

\section{O Modelo Numério DELFT3D-FLOW}

No módulo hidrodinâmico DELFT3D-FLOW, as componentes da equação do movimento A.1 e A.2 correspondem às equações do movimento segundo as direções $x$ e $y$, assumidas como:

$$
\begin{aligned}
& \frac{\partial u}{\partial t}+\frac{u}{\sqrt{G_{x}}} \frac{\partial u}{\partial x}+\frac{v}{\sqrt{G_{y}}} \frac{\partial u}{\partial y}+ \frac{w}{H} \frac{\partial u}{\partial \sigma}-\frac{v^{2}}{\sqrt{G_{x}} \sqrt{G_{y}}} \frac{\partial \sqrt{G_{y}}}{\partial x}+\frac{u v}{\sqrt{G_{x}} \sqrt{G_{y}}} \frac{\partial \sqrt{G_{x}}}{\partial y}-f v= \\
&-\frac{1}{\rho_{0} \sqrt{G_{x}}} P_{x}+F_{x}+\frac{1}{H^{2}} \frac{\partial}{\partial \sigma}\left(v_{m o l}+\frac{\partial u}{\partial \sigma}\right)+M_{x} \quad \text { (A.1) } \\
& \frac{\partial v}{\partial t}+\frac{u}{\sqrt{G_{x}}} \frac{\partial v}{\partial x}+\frac{v}{\sqrt{G_{y}}} \frac{\partial v}{\partial y}+\frac{w}{H} \frac{\partial v}{\partial \sigma}-\frac{u^{2}}{\sqrt{G_{x}} \sqrt{G_{y}}} \frac{\partial \sqrt{G_{y}}}{\partial x}+\frac{u v}{\sqrt{G_{x}} \sqrt{G_{y}}} \frac{\partial \sqrt{G_{x}}}{\partial y}+f u= \\
&-\frac{1}{\rho_{0} \sqrt{G_{y}}} P_{y}+F_{y}+\frac{1}{H^{2}} \frac{\partial}{\partial \sigma}\left(v_{m o l}+\frac{\partial v}{\partial \sigma}\right)+M_{y} \quad \text { (A.2) }
\end{aligned}
$$

Nestas equações, $x, y$ e $z$ são as três coordenadas espaciais e $t$ é o tempo. $u$, $v$ e $w$ são as componentes de corrente segundo os eixos $x, y$ e $z$ e a densidade é simbolizada por $\rho . \sqrt{G_{x}}$ e $\sqrt{G_{y}}$ são coeficientes de transformação de coordenadas curvilineares para retangulares (aproximação que não considera a esfericidade da Terra), $H$ significa a profundidade, $P_{x}$ e $P_{y}$ são os gradientes de pressão hidrostática nas respectivas direções, $F_{x}$ e $\mathrm{F}_{y}$ são os gradientes de tensão radiativa nas respectivas direções, $v_{m o l}$ o coeficiente de viscosidade cinemática molecular, $M_{x}$ e $M_{y}$ são fontes ou sorvedouros de momento nas respectivas direções.

A componente vertical do movimento, na direção $z$, A.3, é reduzida à equação 
hidrostática:

$$
\frac{\partial P}{\partial \sigma}=-g \rho H
$$

Derivadas desta equação, podem ser obtidas as expressões que resolvem os gradientes horizontais de pressão:

$$
\begin{aligned}
& \frac{1}{\rho \sqrt{G_{x}}} P_{x}=\frac{g}{\sqrt{G_{x}}} \frac{\partial \varphi}{\partial x}+g \frac{H}{\rho \sqrt{G_{x}}} \int_{\sigma}^{0}\left(\frac{\partial \rho}{\partial x}+\frac{\partial \rho}{\partial \sigma} \frac{\partial \sigma}{\partial x}\right) d \sigma \\
& \frac{1}{\rho \sqrt{G_{y}}} P_{y}=\frac{g}{\sqrt{G_{y}}} \frac{\partial \varphi}{\partial y}+g \frac{H}{\rho \sqrt{G_{y}}} \int_{\sigma}^{0}\left(\frac{\partial \rho}{\partial y}+\frac{\partial \rho}{\partial \sigma} \frac{\partial \sigma}{\partial y}\right) d \sigma
\end{aligned}
$$

onde, $\varphi$ é a variação da superfície livre e $\sigma$ é o sistema de coordenada vertical introduzido por Phillips (1957).

Nas equações A.4 A.5, do lado direito da igualdade, o primeiro termo é referente ao gradiente de pressão barotrópico (variações da superfície livre), e o segundo ao gradiente de pressão baroclínico (variações laterais de densidade).

Os gradientes de tensão radiativa, $F_{x}$ e $F_{y}$, são descritos por:

$$
\begin{aligned}
& F_{x}=\frac{1}{\sqrt{G_{x}}} \frac{\partial \tau_{x x}}{\partial x}+\frac{1}{\sqrt{G_{y}}} \frac{\partial \tau_{x y}}{\partial y} \\
& F_{y}=\frac{1}{\sqrt{G_{x}}} \frac{\partial \tau_{y x}}{\partial x}+\frac{1}{\sqrt{G_{y}}} \frac{\partial \tau_{y y}}{\partial y}
\end{aligned}
$$

Os tensores $\tau_{x x}, \tau_{x y}, \tau_{y x}$ e $\tau_{y y}$ são determinados de acordo com:

$$
\begin{gathered}
\tau_{x x}=\frac{2 v_{H}}{\sqrt{G_{x}}}\left(\frac{\partial u}{\partial x}+\frac{\partial u}{\partial \sigma} \frac{\partial \sigma}{\partial x}\right) \\
\tau_{x y}=\tau_{y x} v\left\{\frac{1}{\sqrt{G_{y}}}\left(\frac{\partial u}{\partial y}+\frac{\partial u}{\partial \sigma} \frac{\partial \sigma}{\partial y}\right)+\frac{1}{\sqrt{G_{x}}}\left(\frac{\partial v}{\partial x}+\frac{\partial v}{\partial \sigma} \frac{\partial \sigma}{\partial x}\right)\right\} \\
\tau_{y y}=\frac{2 v_{H}}{\sqrt{G_{y}}}\left(\frac{\partial v}{\partial y}+\frac{\partial v}{\partial \sigma} \frac{\partial \sigma}{\partial y}\right)
\end{gathered}
$$

Para a equação da continuidade, (equação A.11), a representação utilizada no DELFT3D-FLOW é:

$$
\frac{\partial \varphi}{\partial t}+\frac{1}{\sqrt{G_{x}} \sqrt{G_{y}}} \frac{\left.\partial(H) U \sqrt{(} G_{y}\right)}{\partial x}+\frac{1}{\sqrt{G_{x}} \sqrt{G_{y}}} \frac{\left.\partial(H) V \sqrt{(} G_{x}\right)}{\partial y}=Q
$$

Na equação A.11. $U$ e $V$ significam os transportes por unidade de distância horizontal nas respectivas direções $x$ e $y$; $Q$ representa as contribuições por unidade de área de descarga ou sumidouro de água. $Q$ é dado por, com $q_{f}$ sendo as fontes e 
$q_{s}$ os sorvedouros:

$$
Q=H \int_{-1}^{0}\left(q_{f}-q_{s}\right) d \sigma
$$

As equações de difusão de sal e calor (equações A.13 e A.14), tendo $\lambda$ como processos de decaimento de primeira ordem, $S$ a salinidade e $T$ a temperatura, são representadas por:

$$
\begin{gathered}
\frac{\partial H S}{\partial t}+\frac{1}{\sqrt{G_{x}} \sqrt{G_{y}}}\left\{\frac{\partial \sqrt{G_{y}} H u S}{\partial x}+\frac{\partial \sqrt{G_{x}} H v S}{\partial y}\right\}+\frac{\partial w S}{\partial \sigma}= \\
\frac{H}{\sqrt{G_{x}} \sqrt{G_{y}}}\left\{\frac{\partial}{\partial x}\left(\frac{D_{H}}{\sigma} \frac{\sqrt{G_{y}}}{\sqrt{G_{x}}} \frac{\partial S}{\partial x}\right)+\left(\frac{D_{H}}{\sigma} \frac{\sqrt{G_{x}}}{\sqrt{G_{y}}} \frac{\partial S}{\partial y}\right)\right\}+ \\
\frac{1}{H} \frac{\partial}{\partial \sigma}\left(\frac{v_{m o l}}{\sigma_{m o l}}+\frac{\partial S}{\partial \sigma}\right)-\lambda H+F s \\
\frac{\partial H T}{\partial t}+\frac{1}{\sqrt{G_{x} \sqrt{G_{y}}}}\left\{\frac{\partial \sqrt{G_{y}} H u T}{\partial x}+\frac{\partial \sqrt{G_{x}} H v T}{\partial y}\right\}+\frac{\partial w T}{\partial \sigma}= \\
\frac{H}{\sqrt{G_{x}} \sqrt{G_{y}}}\left\{\frac{\partial}{\partial x}\left(\frac{D_{H}}{\sigma} \frac{\sqrt{G_{y}}}{\sqrt{G_{x}}} \frac{\partial T}{\partial x}\right)+\left(\frac{D_{H}}{\sigma} \frac{\sqrt{G_{x}}}{\sqrt{G_{y}}} \frac{\partial T}{\partial y}\right)\right\}+ \\
\frac{1}{H} \frac{\partial}{\partial \sigma}\left(\frac{v_{m o l}}{\sigma_{m o l}}+\frac{\partial T}{\partial \sigma}\right)-\lambda H+F t
\end{gathered}
$$

No modelo DELFT3D-FLOW estão discretizadas as equações de conservação de massa e de momentum. O sistema de equações é fechado por uma versão da equação de estado que é função da temperatura, da salinidade e da pressão $(P)$. A versão utilizada é derivada de Eckart (1958):

$$
\rho=\frac{1.000 P_{0}}{\lambda+\alpha_{0} P_{0}}
$$

onde

$$
\begin{gathered}
\lambda=1779,5+11,25 T-0,0745 T^{2}-(3,80+0,01 T) S, \\
\alpha_{0}=0,6980, \\
P_{0}=5890+38 T-0,375 T^{2}+3 S .
\end{gathered}
$$

O DELFT3D-FLOW apresenta vários esquemas de fechamento turbulento e é totalmente não linear, inclusive nas parametrizações dos atritos de fundo e superfície. 
Tendo $g$ como a aceleração da gravidade, $\rho_{0}$ a densidade de referência da água do mar, $\vec{u}_{b}$ a magnitude da velocidade horizontal na primeira camada acima do fundo e $C_{3 D}$ o coefficiente de Chézy, temos o atrito de fundo $\left(\vec{\tau}_{b}\right)$ descrito por:

$$
\vec{\tau}_{b}=\frac{g \rho_{0} \vec{u}_{b}\left|\vec{u}_{b}\right|}{C_{3 D}^{2}}
$$

Com $\rho_{a}$ sendo a densidade do ar, $U_{10}$ a magnitude da velocidade do vento 10 metros acima da superfície livre (dependente do tempo e do espaço) e $C_{d}$ o coeficiente de arrasto dependente de $U_{10}$, temos o atrito de superfície $\left(\vec{\tau}_{s}\right)$ descrito por:

$$
\left|\overrightarrow{\tau_{s}}\right|=\rho_{a} C_{d} U_{10}^{2}
$$

O coeficiente de arrasto $C_{d}$ é dependente da velocidade do vento e é dado por, de acordo com Smith \& Banke (1975b):

$$
C_{d}\left(U_{10}\right)=\left\{\begin{array}{l}
0,00063 \text { se } U_{10}=0(\mathrm{~m} / \mathrm{s}) ; \\
\frac{0,00803 U_{10}}{100} \text { se } 100(\mathrm{~m} / \mathrm{s})<U_{10}>0(\mathrm{~m} / \mathrm{s}) ; \\
0,00723 \text { se } U_{10} \geq 100(\mathrm{~m} / \mathrm{s})
\end{array}\right.
$$

O método numérico do DELFT3D-FLOW é baseado em diferenças finitas. Para discretizar as equações demonstradas acima no espaço, a área é representada por uma grade curvilinea. A configuração das variáveis na grade é do tipo Arakawa-C, com os pontos de pressão (nível) localizados no centro das células e as componentes de velocidade são situados nas faces, de forma perpendicular.

Detalhes sobre a implementação em diferenças finitas das equações descritas podem ser obtidas em Deltares (2010). 